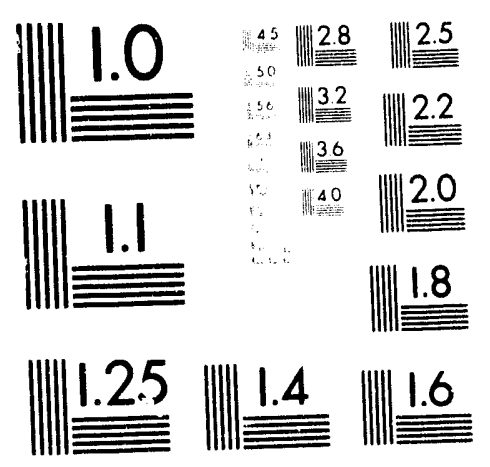



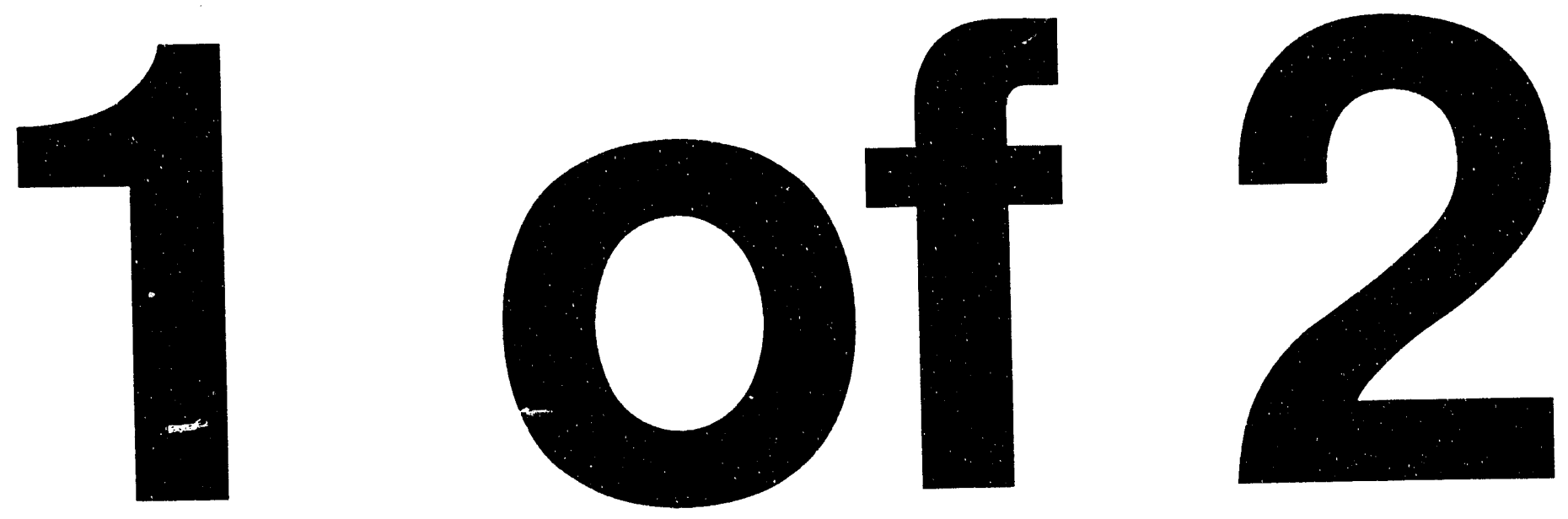


\section{Resource Allocation Support System (RASS): Summary Report of the 1992 Pilot Study}

by W.A. Buehring, R.G. Whitfield, T.D. Wolsko, P.H. Kier, M.J.G. Absil, M.J. Jusko, and P.F. Sapinski

Environmental Assessment and Information Sciences Division, Argonne National Laboratory, 9700 South Cass Avenue, Argonne, Illinois 60439

February 1993

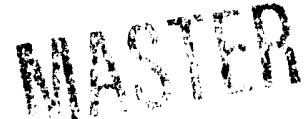

Work sponsored by United States Department of Energy, Assistant Secretary for Environmental Restoration and Waste Management 


\section{CONTENTS}

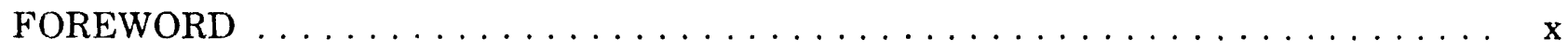

ACKNOWLEDGMENTS $\ldots \ldots \ldots \ldots \ldots \ldots \ldots \ldots \ldots \ldots \ldots \ldots \ldots \ldots$

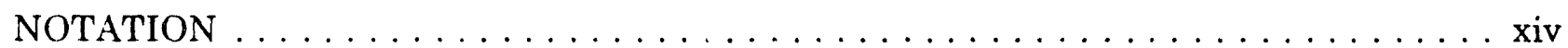

ABSTRACT $\ldots \ldots \ldots \ldots \ldots \ldots \ldots \ldots \ldots \ldots \ldots \ldots \ldots \ldots \ldots \ldots$

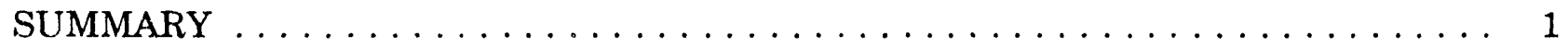

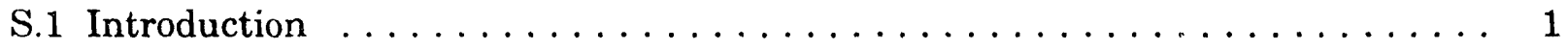

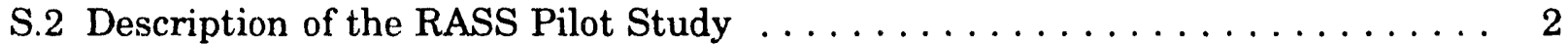

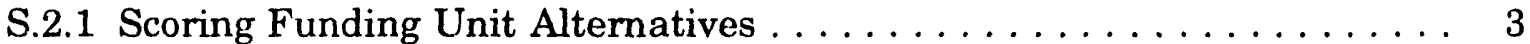

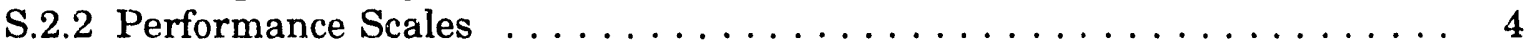

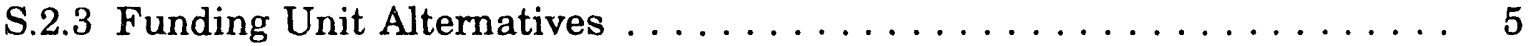

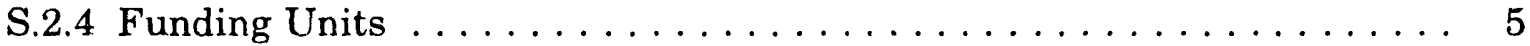

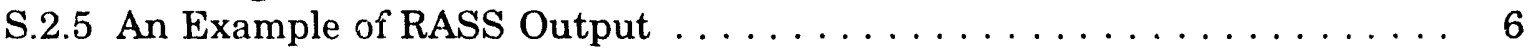

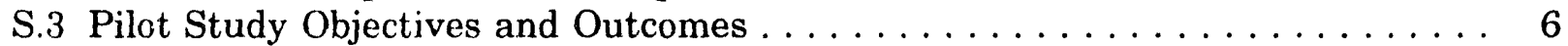

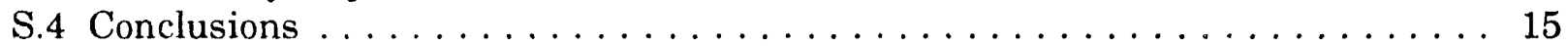

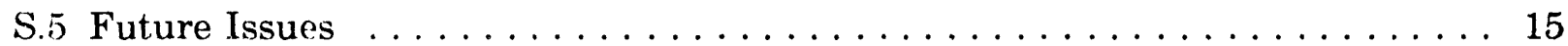

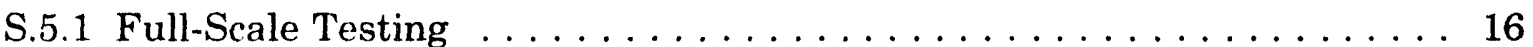

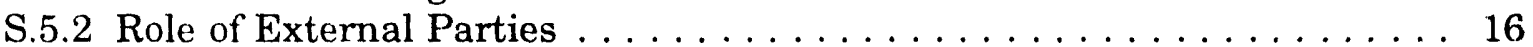

S.5.3 Implementation $\ldots \ldots \ldots \ldots \ldots \ldots \ldots \ldots \ldots \ldots \ldots \ldots$

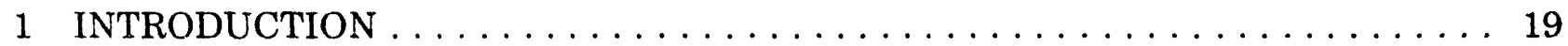

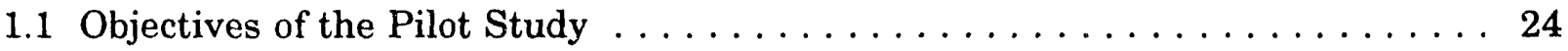

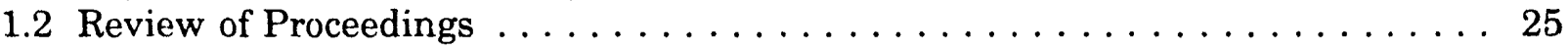

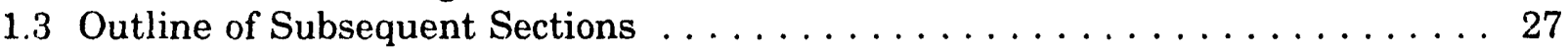

2 OVERVIEW OF RASS METHODOLOGY FOR THE PILOT STUDY . . . . . . . 28

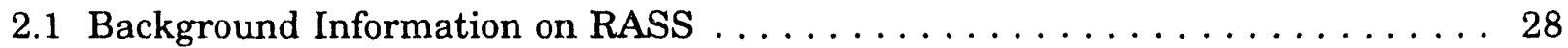

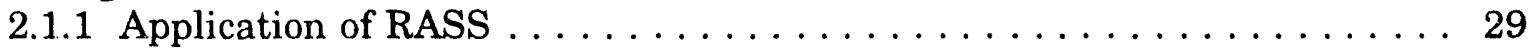

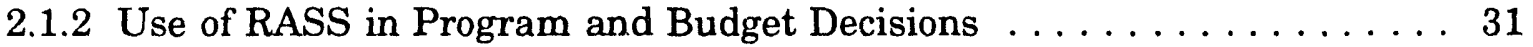

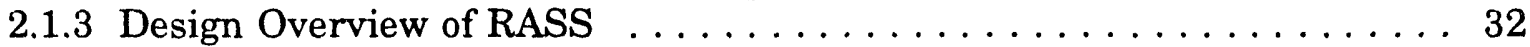

2.2 RASS Objectives for WM and Scales Used in the Pilot Study . . . . . . . 34

2.2 .1 Compliance ........................... 36

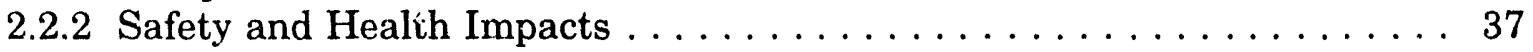

2.2 .3 Waste Managed . . . . . . . . . . . . . . . . . . . . 40

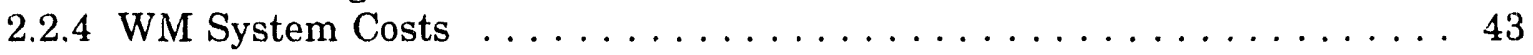

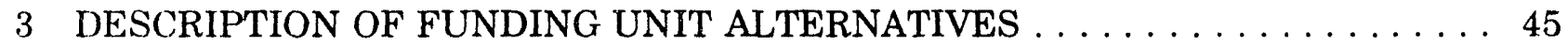




\section{CONTENTS (Cont.)}

4 PUBLIC PARTICIPATION IN THE PILOT STUDY $\ldots \ldots \ldots \ldots \ldots \ldots \ldots \ldots$

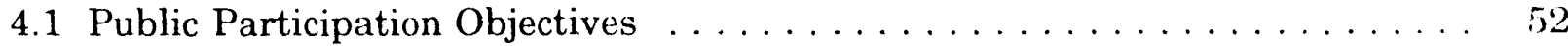

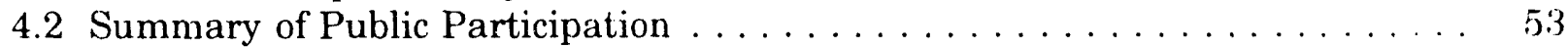

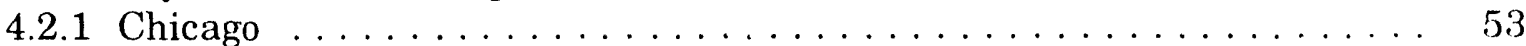

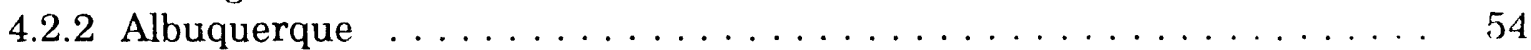

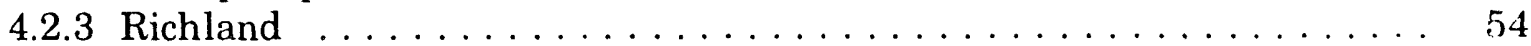

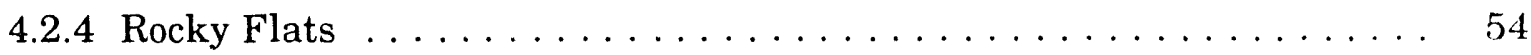

4.2 .5 Consultation on Compliance and Other Scales $\ldots \ldots \ldots \ldots \ldots \ldots \ldots$

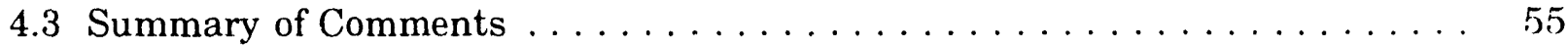

4.4 Preliminary Conclusions $\ldots \ldots \ldots \ldots \ldots \ldots \ldots \ldots \ldots \ldots$

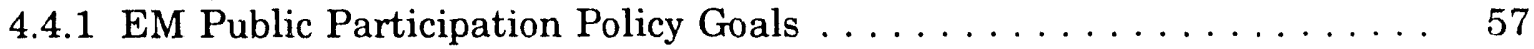

4.4.2 Defining Effective Roles for the Public . . . . . . . . . . . . . . . 59

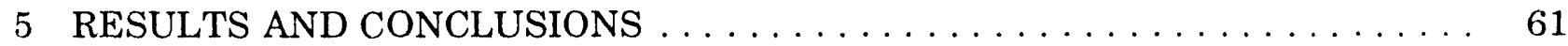

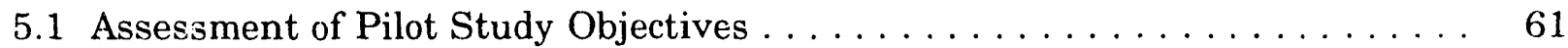

5.2 Results for Reference Substitution Rates . . . . . . . . . . . . . . . . . 64

5.2 .1 Reference Substitution Rates . . . . . . . . . . . . . . . . . 65

5.2.2 Calculating the Equivalent Cost of a Funding Unit Alternative . . . . . 67

5.2 .3 Resource Allocation with the Reference Substitution Rates . . . . . . . 67

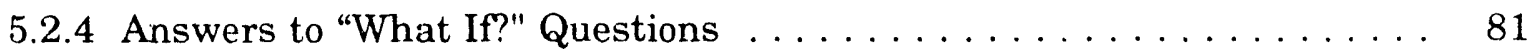

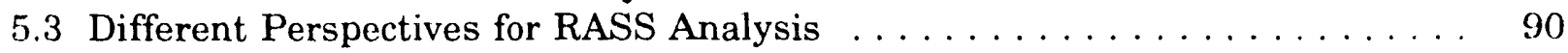

6 ISSUES, LESSONS LEARNED, AND DIRECTIONS FOR

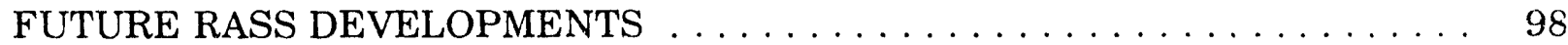

6.1 Issues and Lessons Learned $\ldots \ldots \ldots \ldots \ldots \ldots \ldots$

6.1.1 Characteristics of Funding Unit Altert atives . . . . . . . . . . . . 98

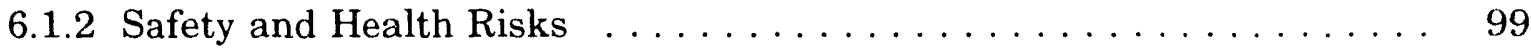

6.1 .3 Meeting Waste Management Needs . . . . . . . . . . . . . . . . . . . . 101

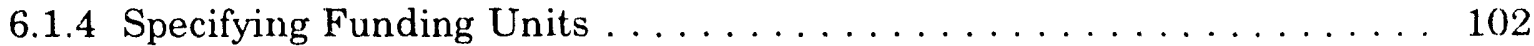

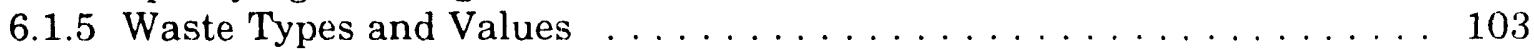

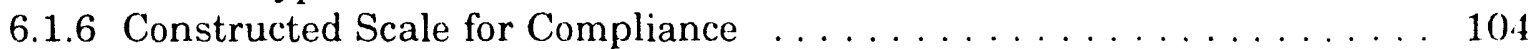

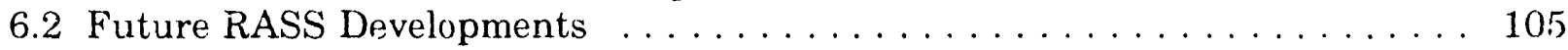

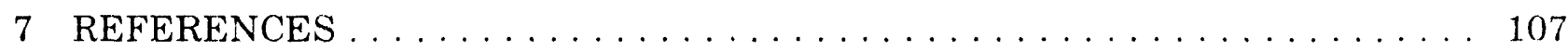

APPENDIX A: Data Form and Specific Insiructions for Completing the Data Form for the RASS Pilot Study . . . . . . . . . . . . . . . 109

APPENDIX B: Background Information on Funding Unit Alternatives

Used in the RASS Pilot Study 


\section{FIGURES}

1 Sources, Types, Forms, and Management of DOE Waste $\ldots \ldots \ldots \ldots \ldots$

2 Groups and Organizations Involved in the RASS Development Process . . . . . . 21

3 Different Perspectives Can Be Used as a Basis for RASS Results . . . . . . . . . . 28

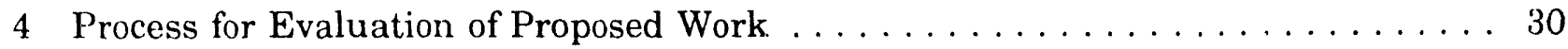

5 Opportunities for RASS Application in the FY 1996 Budget Cycle . . . . . . . . . 32

6 Five Stages of the Resource Allocation Support System . . . . . . . . . . . 33

7 Safety and Health Considerations $\ldots \ldots \ldots \ldots \ldots \ldots \ldots \ldots \ldots$

8 Three Categories of Activities Used to Measure Waste Managed . . . . . . . . . 41

9 Nine Summary Scores for Each Funding Unit Alternative Are Converted into an Equivalent-Cost Figure $\ldots \ldots \ldots \ldots \ldots$

10 A Dynamic Programming Algorithm Uses Target-Year Cost and Equivalent Costs to Allocate Funds among Funding Units . . . . . . . . . 66

11 Equivalent Level-H Counts in All Years for the Compliance Objective versus Total WM Budget . . . . . . . . . . . . . . . . . . . 82

12 Histograms for Equivalent Counts in the Target Year for Each Compliance Level versus Four Total WM Budgets . . . . . . . . . . 86

13 Total Equivalent Fatalities versus WM Budget $\ldots \ldots \ldots \ldots \ldots$

14 Public Equivalent Fatalities versus WM Budget $\ldots \ldots \ldots \ldots \ldots$

15 Occupational Equivalent Fatalities versus WM Budget $\ldots \ldots \ldots \ldots$

16 Throughput in Terms of Equivalent Volume of Low-Level Waste versus WM Budget . . . . . . . . . . . . . . . . . . . 88

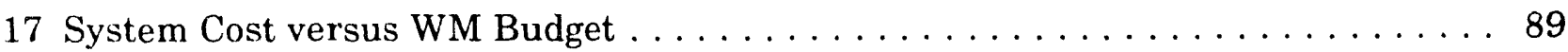

18 Equivalent Level-H Counts versus WM Budget for Three Representative Perspectives . . . . . . . . . . . . . . . . 93

19 (a) Richland, (b) Rocky Flats, (c) Chicago, and (d) Albuquerque Funding versus WM Budget . . . . . . . . . . . . . . . . . 95 


\section{TABLES}

S.1 Funding Units and Alternatives for Richland $\ldots \ldots \ldots \ldots \ldots$

S.2 Funding Units and Alternatives for Rocky Flats . . . . . . . . . . . 8

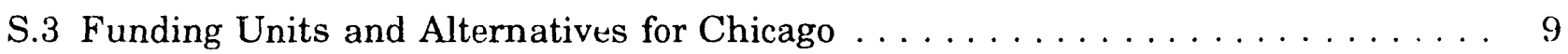

S.4 Funding Units and Alternatives for Albuquerque $\ldots \ldots \ldots \ldots \ldots \ldots$

S.5 Compliance Problems Caused by a $\$ 25.8$ Million Reduction

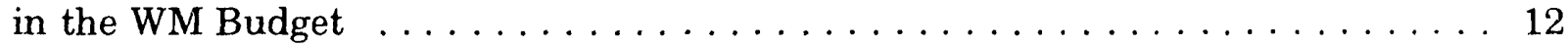

1 Sequence of Events at Each Field Office $\ldots \ldots \ldots \ldots \ldots \ldots \ldots$

2 Constructed Scale for Compliance $\ldots \ldots \ldots \ldots \ldots \ldots \ldots$

3 Constructed Scale for Public Safety and Health Effects Due to Air and Water Exposure Pathways . . . . . . . . . . . . . . . . 39

4 Constructed Scale for Estimating Schedule Delays in Providing New Treatment, Storage, or Disposal Capacity

5 Funding Units for the RASS Pilot Study $\ldots \ldots \ldots \ldots \ldots$

6 Funding Units and Alternatives for Richland $\ldots \ldots \ldots \ldots \ldots$

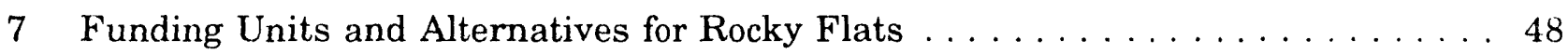

$8 \quad$ Funding Units and Alternatives for Chicago . . . . . . . . . . . . . . 49

9 Funding Units and Alternatives for Albuquerque $\ldots \ldots \ldots \ldots \ldots$

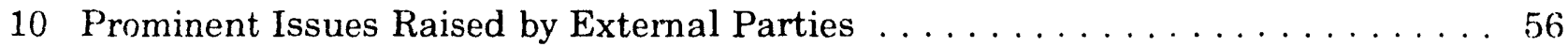

11 Reference Substitution Rates $\ldots \ldots \ldots \ldots \ldots \ldots \ldots$

12 Illustrative Calculations for Obtaining the Equivalent Cost

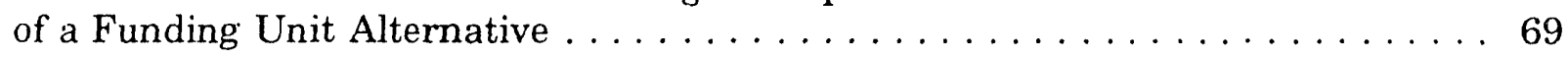

13 Characteristics of Richland Funding Unit Alternatives . . . . . . . . . . 70

14 Characteristics of Rocky Flats Funding Unit Alternatives . . . . . . . . . 71

15 Characteristics of Chicago Funding Unit Alternatives . . . . . . . . . . 72

16 Characteristics of Albuquerque Funding Unit Alternatives . . . . . . . . 73 


\section{TABLES (Cont.)}

17 Funding Allocations for 29 Hypothetical Funding Levels

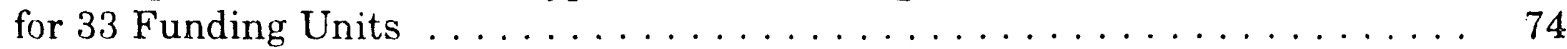

18 Selected Details about the Possible Allocation of a $\$ 280$ Million

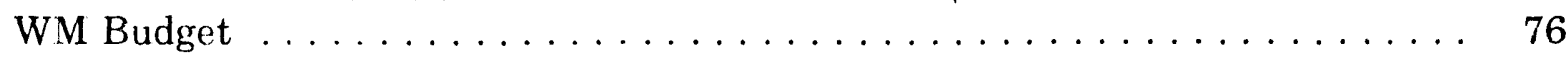

19 An Alternative Representation of Reference RASS Allocation Results . . . . . 77

20 RASS Recommendations for Allocating an Additional \$21 Million

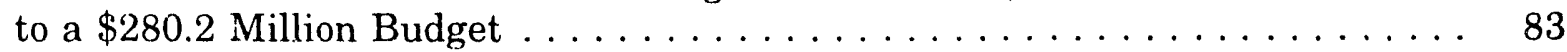

21 Compliance Problems Caused by a $\$ 25.8$ Million Reduction

in the WM Budget $\ldots \ldots \ldots \ldots \ldots \ldots \ldots \ldots \ldots \ldots \ldots \ldots . \ldots \ldots$

22 Comparison of Substitution Rates for RASS Objectives

for WM - Eight Perspectives $\ldots \ldots \ldots \ldots \ldots \ldots \ldots \ldots \ldots \ldots \ldots \ldots$

23 RASS Recommendations for Allocating a $\$ 280$ Million Budget That

Emphasizes Compliance instead of Reference Substitution Rates . . . . . . . 97

B.1 Description of Funding Unit for Hanford Waste Tank

Ferrocyanide Stabilization $\ldots \ldots \ldots \ldots \ldots \ldots \ldots \ldots \ldots \ldots$

B.2 Description of Funding Unit for Hanford Waste Receiving and

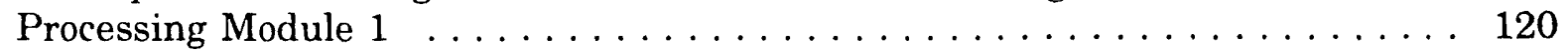

B.3 Description of Funding Unit for Hanford New Double-Shell Waste

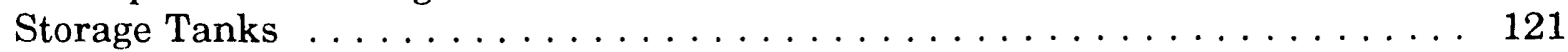

B.4 Description of Funding Unit for Hanford Contact-Handled

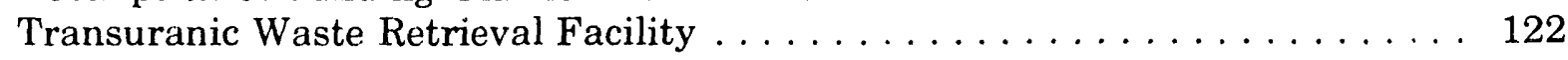

B.5 Description of Funding Unit for Hanford Site Preparation

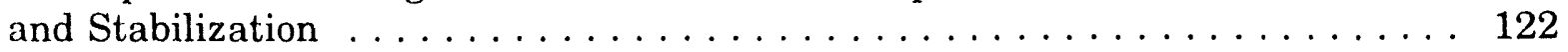

B.6 Description of Funding Unit for Hanford K Basins $\ldots \ldots \ldots \ldots \ldots$

B.7 Description of Funding Unit for Hanford Waste Vitrification

Plant Operations ............................... 124

B.8 Description of Funding Unit for Hanford Grout Disposal Program . . . . . . 125

B.9 Description of Funding Unit for Hanford Environmental Sampling

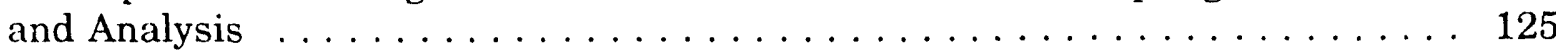

B.10 Description of Funding Unit for Hanford 200-Area Sanitary Sewer … . . 126 


\section{TABLES (Cont.)}

B.11 Description of Funding Unit for Rocky Flats Off-site Transport and

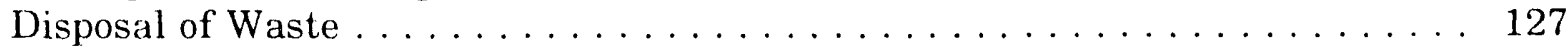

B.12 Description of Funding Unit for Rocky Flats Liquid Waste

Treatment Operations and Upgrade, Bldg. 374

B.13 Description of Funding Unit for PPPL Waste Minimization Program

and Five-Year Plan Administration $\ldots \ldots \ldots \ldots \ldots \ldots \ldots$

B.14 Description of Funding Unit for PPPL Underground Storage

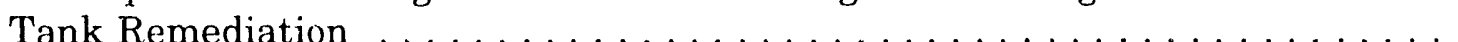

B.15 Description of Funding Unit for PPPL Storm-Water

Discharge Characterization

B.16 Description of Funding Unit for PPPL Radioactive Waste Operations . . . . . 130

B.17 Description of Funding Unit for PPPL Hazardous Waste Operations . . . . . . 131

B.18 Description of Funding Unit for BNL New Hazardous Waste

Management Facility . . . . . . . . . . . . . . . . . .

B.19 Description of Funding Unit for BNL Hazardous Radioactive Waste

Disposal Operations

B.20 Description of Funding Unit for ANL-West Radioactive Sodium

Waste Process Facility . . . . . . . . . . . . . . . . . . . 133

B.21 Description of Funding Unit for ANL-West Liquid Effluent Monitoring . . . . 133

B.22 Description of Funding Unit for ANL-West LLW Disposal to the Radioactive Waste Management Complex

B.23 Description of Funding Unit for ANL-East Laboratory Wastewater

Treatment Plant Upgrade

B.24 Description of Funding Unit for ANL-East Continuity of Operations

B.25 Description of the Funding Unit for LANL TRU Solid Waste

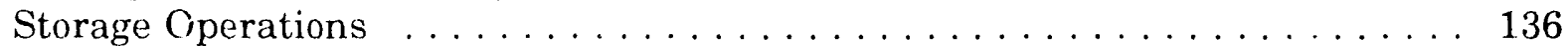

B.26 Description of the Funding Unit for LANL Radioactive

Liquid Waste Treatment

B.27 Description of the Funding Unit for LANL Low-Level Radioactive

Waste Disposal 


\section{TABLES (Cont.)}

B.28 Description of the Funding Unit for KCP Replacement

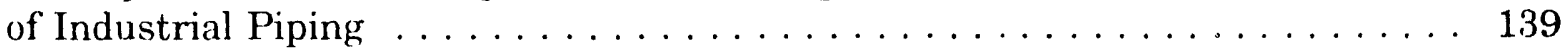

B.29 Description of Funding Unit for KCP Modification

of Demolition Lot . . . . . . . . . . . . . . . . . . . . . . . . . . . . 140

B.30 Description of Funding Unit for KCP Facility Operations

and Maintenance ............................ 141

B.31 Description of the Funding Unit for Mound Plant Radioactive

Waste Management . . . . . . . . . . . . . . . . . . . . . . . . . 143

B.32 Description of the Funding Unit for Mound Plant Mixed

Waste Management . . . . . . . . . . . . . . . . . . . . . . . . . . 144

B.33 Description of the Funding Unit for Mound Plant Hazardous

Waste Management . . . . . . . . . . . . . . . . . . . . . . . . 145 


\section{FOREWORD}

This document summarizes a pilot study of the Resource Allocation Support System (RASS), a decision-aiding system being developed for the U.S. Department of Energy's Office of Waste Management to assist in making better informed program and budget decisions. It summarizes the overall results of pilot studies conducted at four field offices (Albuquerque, Chicago, Rocky Flats, and Richland) from June to September 1992. This document is an overall pilot study summary report that combines results from all four field offices. Four other documents serve as reference documents for the individual pilot studies at each field office. The purpose of this document is to improve the potential for successful development and application of RASS by describing the pilot study experience. Comments from readers are welcome. Replies should be directed to one of the following individuals:

Kevin Donovan

U.S. Department of Energy

Trevion II

Office of Waste Management

EM-333

Washington, DC 20585-0002

Telephone: (301) 903-7671

Facsimile: (301) 903-7166

Thomas D. Wolsko

Argonne National Laboratory

Environmental Assessment and

Information Sciences Division

Systems Science Group

9700 South Cass Avenue

Building 900

Argonne, IL 60439-4832

Telephone: (708) 252-3727

Facsimile: (708) 252-6073 


\section{ACKNOWLEDGMENTS}

The authors wish to thank a number of individuals for their contributions to this document. James Turi, Joel Kristal, and Kevin Donovan of the U.S. Department of Energy (DOE) provided guidance and encouragement throughout the Resource Allocation Support System (RASS) pilot study. Ralph Keeney and Detlof von Winterfeldt of the University of Southern California provided important suggestions on how to address the resource allocation problem. John Shideler of J.K. Research Associates led the public participation process for RASS and contributed Section 4 of this report. Members of the DOE Field Office/Headquarters Working Group were supportive throughout the RASS development process and the pilot study. Members of the Technical Review Group examined the original draft design concept for RASS and provided helpful guidance. Many members of the public generously gave their time to discuss early development plans for RASS, to participate in the January 1992 national workshop, to review proposed scales to be used in RASS, and to participate in the pilot study.

The following individuals participated in the RASS pilot study and associated meetings. Their cooperation, suggestions, and efforts are greatly appreciated. Their participation does not imply approval of the methodology or the results of the pilot study. The authors also thank the other individuals who prepared materials for the pilot study but did not attend the meetings.

\section{Albuquerque}

Debbie Burnett

Orin Critchfield

Tim Frazier

David Huyett

Richard Mullins

Brian Myers

Jim Orban

Margaret Stockdale

Steve Tunning

Mona Williams
Allied Signal - Kansas City Plant

U.S. Department of Energy

U.S. Department of Energy

Allied Signal - Kansas City Plant

Allied Signal - Kansas City Plant

Los Alamos National Laboratory

U.S. Department of Energy

U.S. Department of Energy

EG\&G - Mound Plant

U.S. Department of Energy

\section{Chicago}

Tony Bindokas

Mark Bollinger

Joel Haugen

Mike Klimas

Ray Lang

Wesley Price

Steve Webster
U.S. Department of Energy

U.S. Department of Energy

U.S. Department of Energy

U.S. Department of Energy

U.S. Department of Energy

Dames \& Mcore

U.S. Department of Energy 


\section{Richland}

Anna Beard-Taylor

Jeff Breckel

Suzanne Bussman

Rudy Carreon

Jack D. Cloud

Bob Cook

Dan Danch

James Daniels

Bill Edwards

John Erikson

Janet Franco

Bob Fritz

Kenneth A. Gasper

Carl Haller

Chuck Hatch

Vic Hoefer

Mark Holt

W.G. Jasen

Dan Josue

Duane Lee

Gary A. Meyer

Norman Moorer

Jon C. Peschong

Beth Schultz

Michael Simpson

Randy Small

Rex Thompson

Detlof von Winterfeldt

J.R. Wilkinson

Ralph Wood
U.S. Department of Energy

State of Washington Department of Ecology

Westinghouse Hanford Company

U.S. Department of Energy

Kaiser Engineers Hanford

Yakima Indian Nation

Westinghouse Hanford Company

Westinghouse Hanford Company

U.S. Department of Energy

State of Washington Department of Health

Oregon Department of Energy

Westinghouse Hanford Company

Westinghouse Hanford Company

Westinghouse Hanford Company

Westinghouse Hanford Company

Westinghouse Hanford Company

Congressional Research Service

Westinghouse Hanford Company

State of Washington Department of Ecology

Westinghouse Hanford Company

Westinghouse Hanford Company

U.S. Department of Energy

U.S. Department of Energy

Westinghouse Hanford Company

Congressional Research Service

U.S. Department of Energy

Westinghouse Hanford Cos upany

University of Southern California

Confederated Tribes of the Umatilla Reservation

Westinghouse Hanford Company

\section{Rocky Flats}

\author{
Len Ackland \\ Paul Aguilar \\ Donald M. Anderson \\ Ed Barry \\ Gary Baughman \\ Norman P. Cypher \\ Jonathor Dion \\ H. FlaHavhan \\ Harris L. Gloe \\ Martin Hestmark
}

\author{
Colorado University \\ EG\&G \\ EG\&G \\ EG\&G \\ Colorado Department of Heaith \\ EG\&G \\ U.S. Department of Energy \\ EG\&G \\ EG\&G \\ U.S. Environmental Protection Agency - Rigion VIII
}




\section{NOTATION}

The following is a list of acronyms, abbreviations, and initialisms used in this document.

ADS activity data sheet (WM program planning and budgeting document)

AI Albuquerque DOE Field Office

ALARA as low as reasonably achievable

ANL Argonne National Laboratory

BNL Brookhaven National Laboratory

BOD biological oxygen demand

CERCLA Comprehensive Environmental Response, Compensation, and Liability Act

$\mathrm{CH}$

CTMP

CWA Chicag? DOE Field Office Comprehensive Treatment Management Plan

D\&D

DOE Clean Water Act

EBR-II Experimental Breeder Reactor-II

EM

EPA

ER

decontamination and decommissioning

U.S. Department of Energy

$\mathrm{FeCN}$ DOE Office of Environmental Restoration and Waste Management U.S. Environmental Protection Agency

ferrocyanide

FFCA Federal Facility Compliance Agreement

FY

fiscal year

HAZ hazardous waste

HDW EIS Hanford Defense Waste Environmental Impact Statement

HGDP

HLW

$\mathrm{HQ}$

HWMF

HWVP

ID

IWPF Hanford Grout Disposal Program

high-level radioactive waste

Headquarters (DOE)

Hazardous Waste Management Facility

Hanford Waste Vitrification Plant

KCP Kansas City Plant

LANL Los Alamos National Laboratory

LDR land disposal restriction

LLW low-level waste

MWSF Mixed Waste Storage Facility

MWTF Multifunction Waste Tank Facility 


$\begin{array}{ll}\text { Gary N. Huffman } & \text { U.S. Department of Energy } \\ \text { Frank Humbert } & \text { EG\&G } \\ \text { Melinda Kassen } & \text { Environmental Defense Fund } \\ \text { David Lam } & \text { EG\&G } \\ \text { Debbie Mauer } & \text { U.S. Department of Energy } \\ \text { David Maxwell } & \text { U.S. Environmental Protection Agency - Region VIII } \\ \text { David Michel } & \text { EG\&G } \\ \text { Dan Miller } & \text { Colorado Attorney General Office } \\ \text { Fred Miller } & \text { Oak Ridge K-25 Site } \\ \text { Carol O'Dowd } & \text { Athena's Consulting Network } \\ \text { Jerry O'Leary } & \text { EG\&G } \\ \text { Glenn Pirson } & \text { EG\&G } \\ \text { Gary Poling } & \text { EG\&G } \\ \text { Ginger Swartz } & \text { Colorado Council on Rocky Flats } \\ \text { Mary Vargas } & \text { U.S. Department of Energy } \\ \text { Joe Wienand } & \text { U.S. Department of Energy } \\ \text { Phil Wilgers } & \text { EG\&G } \\ \text { Judy Zwickl } & \text { EG\&G }\end{array}$

Participation in the RASS pilot study was strictly voluntary. The authors thank the Albuquerque, Chicago, Richland, and Rocky Flats offices for their willingness to dedicate the time and people needed to make the RASS pilot study a meaningful effort.

The authors also thank the many reviewers of an early draft of this document. Reviewers included members of the DOE Field Office/Headquarters Working Group and the Technical Review Group. Although the reviewers provided many helpful comnients and suggestions that improved the report, the authors take responsibility for its content.

It is a pleasure to acknowledge the efforts of those at Argonne National Laboratory's Information and Publishing Division who were instrumental in preparing this report. Margaret Clemmons improved the format and language of the report through her careful editing. Linda Haley and Holly Seguine provided the graphics. The Document Processing Center provided word processing support. 
NESHAPs National Emission Standards for Hazardous Air Pollutants

NJAC New Jersey Administrative Code

NJDEPE New Jersey Department of Environmental Protection and Energy

NPDES

NRC

NTS

National Pollution Discharge Elimination System

OMB

OSHA

OTA

U.S. Nuclear Regulatory Commission

Nevada Test Site

PAAA

PCB

Office of Management and Budget

Occupational Safety and $\mathrm{Hr}$ alth Administration

Office of Technology Assess ment

PPPL

Price Anderson Act Amendments

PVC

polychlorinated biphenyls

Princeton Plasma Physics Laboratory

polyvinyl chloride

QA

quality assurance

$\mathrm{QC}$

quality control

RASS

Resource Allocation Support System

RCRA

Resource Conservation Recovery Act

$R \& D$

$\mathrm{RF}$

research and development

RL

Rocky Flats DOE Office

RWMC Radioactive Waste Management Complex

SAR safety analysis report

$\mathrm{S} \& \mathrm{H} \quad$ safety and health

TDD

TFTR

task description document (a component of an ADS)

TPA

Tokamak Fusion Test Reactor

TRG

TRU

Tri-Party Agreement

Technical Review Group

transuranic (waste)

TSCA

Toxic Substance Control Act

TSD

treatment, storage, and disposal

UST underground storage tank

WAC

WERF

WIPP

WM

WRAP

WW'TP

waste acceptance criteria

Waste Experimental Reduction Facility

Waste Isolation Pilot Plant

Office of Waste Management (EM-30)

Waste Receiving and Processing

Wastewater Treatment Plant 


\title{
RESOURCE ALLOCATION SUPPORT SYSTEM (RASS): SUMMARY REPORT OF THE 1992 PILOT STUDY
}

by

\author{
W.A. Buehring, R.G. Whitfield, T.D. Wolsko, P.H. Kier, \\ M.J.G. Absil, M.J. Jusko, and P.F. Sapinski
}

\begin{abstract}
The Resource Allocation Support System (RASS) is a decision-aiding system being developed to assist the U.S. Department of Energy's (DOE's) Office of Waste Management in program and budget decision making. Four pilot studies were conducted at DOE field offices in summer 1992 to evaluate and improve the RASS design. This report summarizes the combined results of the individual field office pilot studies. Results are presented from different perspectives to illustrate the type of information that would be available from RASS. Lessons learned and directions for future RASS developments are also presented.
\end{abstract}

\section{SUMMARY}

\section{S.1 INTRODUCTION}

The Resource Allocation Support System (RASS) is a decision-aiding system being developed to assist the U.S. Department of Energy's (DOE's) Office of Waste Management (WM) in program and budget decision making. A pilot study was conducted to test the practicality of the RASS design concept as an aid in evaluating proposed work across the WM system. This study involved testing the design and basic concepts of RASS, testing the RASS process and scoring procedure, and evaluating the RASS allocation process and its results. This report summarizes the process and combined results of pilot studies conducted at the Richland (RL), Rocky Flats (RF), Chicago (CH), and Albuquerque (AL), DOE field offices from June to September 1992.

The proposal to develop RASS resulted from two needs:

- To provide WM decision makers with better information about WM program and budget proposals, and

- To assure Congress that WM funds are well spent.

Several questions are generated from these needs. For example, how well do the proposals address the protection of the safety and health $(\mathrm{S} \& \mathrm{H})$ of workers and the public, and how 
well do the proposals meet WM's objectives, including compliance with laws, treaties, regulations, and agreements (e.g., tri-party agreements, interagency agreemer.t.s)? To better answer these and similar questions, WM wants to generate insights about proposals that are forwarded to DOE Headquarters for consideration.

The RASS development process involved interactions with three groups:

- DOE Field Office/Headquarters (FO/HQ) Working Group. This group consists of DOE field office and Headquarters staff who will be the primary users of RASS. This group provides a practical perspective on reasonable and acceptable characteristics for RASS. Meetings with this group were held in July and December 1991 and in February, May, and November 1992.

- Technical Review Group (TRG). This group of experts in decision analysis, operations research, risk estimation, and program planning helps ensure that RASS is technically sound and credible. Meetings were held with the TRG in December 1991 and December 1992 to review RASS and its development process. Members of the TRG reviewed relevant materials between those meetings.

- External parties. Interviews were conducted with more than 80 persons in summer/fall 1991 as initial concepts for RASS were studied. These individuals represented more than 50 organizations external to DOE. Some of these individuals participated in a national workshop in January 1992 to discuss the RASS draft design concept. ${ }^{1}$ External parties participated in the Richland and Rocky Flats pilot -tudies. A second national workshop, scheduled for March 1993, will examine the results of the pilot study.

\section{S.2 DESCRIPTION OF THE RASS PILOT STUDY}

To describe how RASS operates, it is necessary to define three related terms: activity, funding unit, and funding unit alternative. An activity is a specific proposal for work, such as new construction; an upgrade to an existing facility; routine maintenance; treatment, storage, or disposal of waste; or monitoring of the environment. A funding unit, the decision unit in RASS, is a logical grouping of activities consistent with WM program planning. A funding unit may be an installation, a facility, or a major activity. A funding unit alternative is a funding unit with specified levels of funding for each included activity. The activity data sheet (ADS), the WM program planning and budgeting document currently in use, generally summarizes proposed activities for one funding unit but sometimes addresses more than one funding unit.

1 Buehring, W.A., R.G. Whitfield, and T.D. Wolsko, 1992, Argonne National Laboratory, Argonne, Ill., unpublished information. 
For example, the $\mathrm{K}$ Basins at Hanford were considered to be one funding unit in the RASS pilot study. The K-East and K-West basins are used to store irradiated nuclear fuel. The Hanford $\mathrm{K}$ Basin funding unit consisted of five activities (most funding units in the RASS pilot study had fewer than five activities):

- Ensure continuity of operations (including maintenance and surveillance),

- Upgrade basins (including encapsulation and repackaging),

- Respond to regulations (including environmental oversight and sampling and monitoring),

- Extend the life of the basins (including security and seismic equipment), and

- Construct a water supply system (new water plant to save on operation and maintr nance costs and to conserve energy).

Three funding unit alternatives were analyzed for this funding unit. The alterrative with the highest funding request addressed the needs of all five activities. The alternative with the lowest funding request achieved minimal or no progress on the five activities. The third alternative was between the high and low alternatives in funding request and in achievement of needed work.

\section{S.2.1 Scoring Funding Unit Alternatives}

Each funding unit alternative included in the pilot study was scored (rated) with respect to RASS objectives for WM. For the RASS pilot study, these objectives addressed the following issues:

- Compliance with regulations, orders, treaties, and agreements;

- Near-term risks to human safety and health;

- DOE waste management needs; and

- WM system costs.

Other potential RASS objectives for WM were identified during discussions with the three groups involved in the development process (Section S.1). Several of these objectives are being studied and may be added to RASS for the proposed full-scale test. 


\section{S.2.2 Performance Scales}

Nine scales were defined to measure performance with respect to the four RASS objectives for WM listed in Section S.2.1. Compliance for proposed WM work and cost of the WM system are each measured by a single scale (scales 1 and 9 , respectively). Safety and health impacts are measured by four separate scales (2-5), and waste managed has three scales of performance (scales 6-8). The nine scales are:

1. Compliance - A scale comprised of categories that indicate the "state of compliance" that may result from proposed expenditures in a given year.

2. Morbidity and mortality for the public (air, groundwater, and surfacewater exposure pathways) - Morbidity is converted to equivalent mortality. Estimates include radiation and chemical risks to humans from exposures through air, groundwater, or surface-water pathways.

3. Morbidity and mortality for the public (transportation accidents) Separate calculations that account for risks due to transporting wastes off-site.

4. Morbidity and mortality for workers - Calculations for workers, including risks due to construction and operations activities.

5. Safety program expenditures - The present value of funds, beyond those required by laws or agreements, to be used for programs designed to reduce $\mathrm{S} \& \mathrm{H}$ risks.

6. Capacity/throughput - An estimate of the amount of waste to be treated, stored, transported, or disposed. Although WM's primary activities involve high-level, low-level, transuranic, sanitary, hazardous, and mixed wastes, RASS allows for other types of activities.

7. New capacity status - A measure of the schedule status for new construction activities (e.g., for new treatment, storage, or disposal facilities). This scale includes upgrades to existing facilities and equipment.

8. Five-Year Plan milestones met - An account of performance with respect to meeting Headquarters-tracked Five-Year Plan milestones.

9. Waste Management system costs - The present value of budget requests, system cost savings, and system cost penalties (e.g., fines). 


\section{S.2.3 Funding Unit Alternatives}

As many as four alternatives were examined for each funding unit in the pilot study. These alternatives differ in the level of funding allotted to a funding unit. For the pilot study, the funding unit alternatives were defined as follows:

- Core: This alternative has the lowest funding request in the target year. It generally includes funding to maintain equipment or a facility in a safe and ready-to-operate (stand-by) mode but does not provide operating funds. This alternative addresses activities only in the standby mode and may incur compliance problems because of its standby status.

- Intermediate: This alternative represents a funding option between the core and operations alternatives.

- Operations: 'This alternative includes all operating, maintenance, and capital expenses needed to conduct scheduled waste management activities in a safe, efficient manner and achieves compliance to the degree possible with all applicable laws, regulations, agreements, treaties, and DOE orders. This alternative usually corresponds to the "target" funding request prepared for the fiscal year (FY) 1994 ADS.

- Long range: This alternative has the highest funding request in the target year. It includes facility upgrades or new construction. Activities for this alternative include facilities that offer long-range benefits to the waste management system. This alternative often corresponds to the "planning" funding request prepared for the FY 1994 ADS.

Participants were not required to define four alternatives for the pilot study. When it could be done without great difficulty, four alternatives were defined. In general, two or three alternatives were used per funding unit.

\section{S.2.4 Funding Units}

The pilot study included 33 funding units, with a maximum total WM funding request of more than $\$ 300$ million for FY 1994 and a minimum funding request of $\$ 115$ million. Richland defined 10 funding units that covered a wide range of activities from grout disposal to building demolitions. Rocky Flats defined 2 funding units that included off-site transport of wastes and operation and upgrade of a liquid waste treatment facility. Chicago scored 12 funding units that included a wide range of activities at four sites (Princeton Plasma Physics Laboratory [PPPL], Brookhaven National Laboratory [BNL], Argonne National Laboratory [ANL]-West, and ANL-East). The Albuquerque pilot study examined 9 funding units from three sites (Los Alamos National Laboratory [LANL], Kansas City Plant [KCP], and Mound Plant). A total of 96 funding unit alternatives were defined for the pilot study. 
Tables S.1-S.4 summarize funding unit alternatives for Richland, Rocky Flats, Chicago, and Albuquerque, respectively. For each funding unit alternative defined, the tables list the target-year cost in thousands of dollars for FY 1994. For example, three alternatives were defined for KCP Facility Operations and Maintenance (Table S.4, funding unit AL6): the maximum target-year cost is $\$ 6,662,000$ for the operations alternative, and the minimum target-year cost is $\$ 808,000$ for the core alternative.

\section{S.2.5 An Example of RASS O utput}

Table S.5 gives an example of the type of output that can be obtained from RASS. Information shown in this table addresses the question: "What are the compliance implications of a budget decrease of $\$ 25.8$ million (from $\$ 305.4$ million, which is the sum of the largest requests from each funding unit, to $\$ 279.6$ million)? ${ }^{n}$ Such a budget reduction could be spread among seven funding units in the manner indicated in Table S.5. This reduction necessarily results in reduced performance with respect to many objectives, one of which involves compliance. This particular set of budget reductions affects performance with respect to compliance at five funding units. The compliance "problems" that would arise involve the following:

- Increased probability of failure to meet a DOE order;

- Failure to meet DOE orders, Occupational Safety and Health Administration (OSHA) regulations, or Resource Conservation Recovery Act (RCRA) regulations; and

- Failure to meet Tiger Team milestones.

Different ways of reducing the budget by $\$ 25.8$ million would have different implications, not only with respect to compliance but to the other objectives as well. Tables similar to Table S.5 for compliance could be constructed for any proposed or hypothetical total WM budget and one or more of the measures of performance in RASS.

\section{S.3 PILOT STUDY OBJECTIVES AND OUTCOMES}

Six pilot study objectives were selected on the basis of discussions with the DOE FO/HQ Working Group, the TRG, and external parties. These objectives and the outcomes from the pilot study are listed below.

- Objective: Determine whether proposed activities can ive meaningfully evaluated on the scales developed to score funding unit alternatives for RASS objectives for WM. 
TABLE S.1 Funding Units and Alternatives for Richland

\begin{tabular}{|c|c|c|c|}
\hline \multicolumn{2}{|c|}{ Funding Unit Number and Name } & Alternative & $\begin{array}{l}\text { Target-Year } \\
\text { Cost }\left(\$ 10^{3}\right) \\
\end{array}$ \\
\hline RL1, & $\begin{array}{l}\text { Waste Tank Ferrocyanide } \\
\text { Stabilization }\end{array}$ & $\begin{array}{l}\text { Long range } \\
\text { Operations } \\
\text { Intermediate } \\
\text { Core }\end{array}$ & $\begin{array}{l}29,952 \\
19,764 \\
15,823 \\
10,400\end{array}$ \\
\hline RL2, & $\begin{array}{l}\text { Waste Receiving and } \\
\text { Processing Module } 1\end{array}$ & $\begin{array}{l}\text { Long range } \\
\text { Operations } \\
\text { Intermediate } \\
\text { Core }\end{array}$ & $\begin{array}{r}{ }^{a} \\
23,71 \dot{2} \\
16,245 \\
0\end{array}$ \\
\hline RL3, & $\begin{array}{l}\text { New Double-Shell Waste } \\
\text { Storage Tanks }\end{array}$ & $\begin{array}{l}\text { Long range } \\
\text { Operations } \\
\text { Intermediate } \\
\text { Core }\end{array}$ & $\begin{array}{r}28,600 \\
28,600 \\
- \\
28,600\end{array}$ \\
\hline RL4, & $\begin{array}{l}\text { Contact-Handled TRU Waste } \\
\text { Retrieval Facility }\end{array}$ & $\begin{array}{l}\text { Long range } \\
\text { Operations } \\
\text { Intermediate } \\
\text { Core }\end{array}$ & $\begin{array}{r}- \\
5,451 \\
1,088 \\
0\end{array}$ \\
\hline RL5, & $\begin{array}{l}\text { Site Preparation and } \\
\text { Stabilization }\end{array}$ & $\begin{array}{l}\text { Long range } \\
\text { Operations } \\
\text { Intermediate } \\
\text { Core }\end{array}$ & $\begin{array}{r}2,188 \\
- \\
- \\
0\end{array}$ \\
\hline RL6, & K Basins & $\begin{array}{l}\text { Long range } \\
\text { Operations } \\
\text { Intermediate } \\
\text { Core }\end{array}$ & $\begin{array}{r}- \\
35,770 \\
15,200 \\
156\end{array}$ \\
\hline RL7, & $\begin{array}{l}\text { Hanford Waste Vitrification } \\
\text { Plant Operations }\end{array}$ & $\begin{array}{l}\text { Long range } \\
\text { Operations } \\
\text { Intermediate } \\
\text { Core }\end{array}$ & $\begin{array}{r}6,545 \\
4,673 \\
- \\
3,224\end{array}$ \\
\hline RL8, & Grout Disposal Program & $\begin{array}{l}\text { Long range } \\
\text { Operations } \\
\text { Intermediate } \\
\text { Core }\end{array}$ & $\begin{array}{r}54,497 \\
53,470 \\
- \\
33,488\end{array}$ \\
\hline
\end{tabular}


TABLE S.1 (Cont.)

\begin{tabular}{llr}
\hline Funding Unit Number and Name & Alternative & $\begin{array}{r}\text { Target-Year } \\
\text { Cost }\left(\$ 10^{3}\right)\end{array}$ \\
\hline \multirow{2}{*}{ RL9, Environmental Sampling } & Long range & - \\
& Operations & 10,033 \\
& Intermediate & 6,240 \\
& Core & 6,240 \\
RL10, 200-Area Sanitary Sewer & Long range & 357 \\
& Operations & 357 \\
& Intermediate & - \\
& Core & 0 \\
\hline
\end{tabular}

a Indicates that the funding unit manager did not develop this alternative.

TABLE S.2 Funding Units and Alternatives for Rocky Flats

\begin{tabular}{llr}
\hline Funding Unit Number and Name & Alternative & $\begin{array}{r}\text { Target-Year } \\
\text { Cost }\left(\$ 10^{3}\right)\end{array}$ \\
\hline \multirow{2}{*}{ RF1, Off-site Transport and } & Long range & $-^{\mathrm{a}}$ \\
Disposal of Waste & $\begin{array}{l}\text { Operations } \\
\text { Intermediate }\end{array}$ & 4,056 \\
& Core & 459 \\
& & \\
RF2, Liquid Waste Treatment & Long range & 19,282 \\
Operations and Upgrade, & Operations & 16,640 \\
Bldg. 374 & Intermediate & - \\
& Core & 10,400 \\
\hline
\end{tabular}

a Indicates that the funding unit manager did not develop this alternative.

Outcome: Pilot study participants were generally successful in scoring a diverse set of activities on RASS pilot study scales. Some difficulties were encountered in the early pilot studies (Chicago and Albuquerque), which required slight modifications to some scales. These scale changes improved the accuracy of scoring and provided scorers with more meaningful scales. For example, the compliance scale was modified to more accurately reflect the expected DOE regulatory actions. Also, additional guidance was required to improve scoring consistency on the compliance scale because some inconsistency occurred in scoring funding units. 
TABLE S.3 Funding Units and Alternatives for Chicago

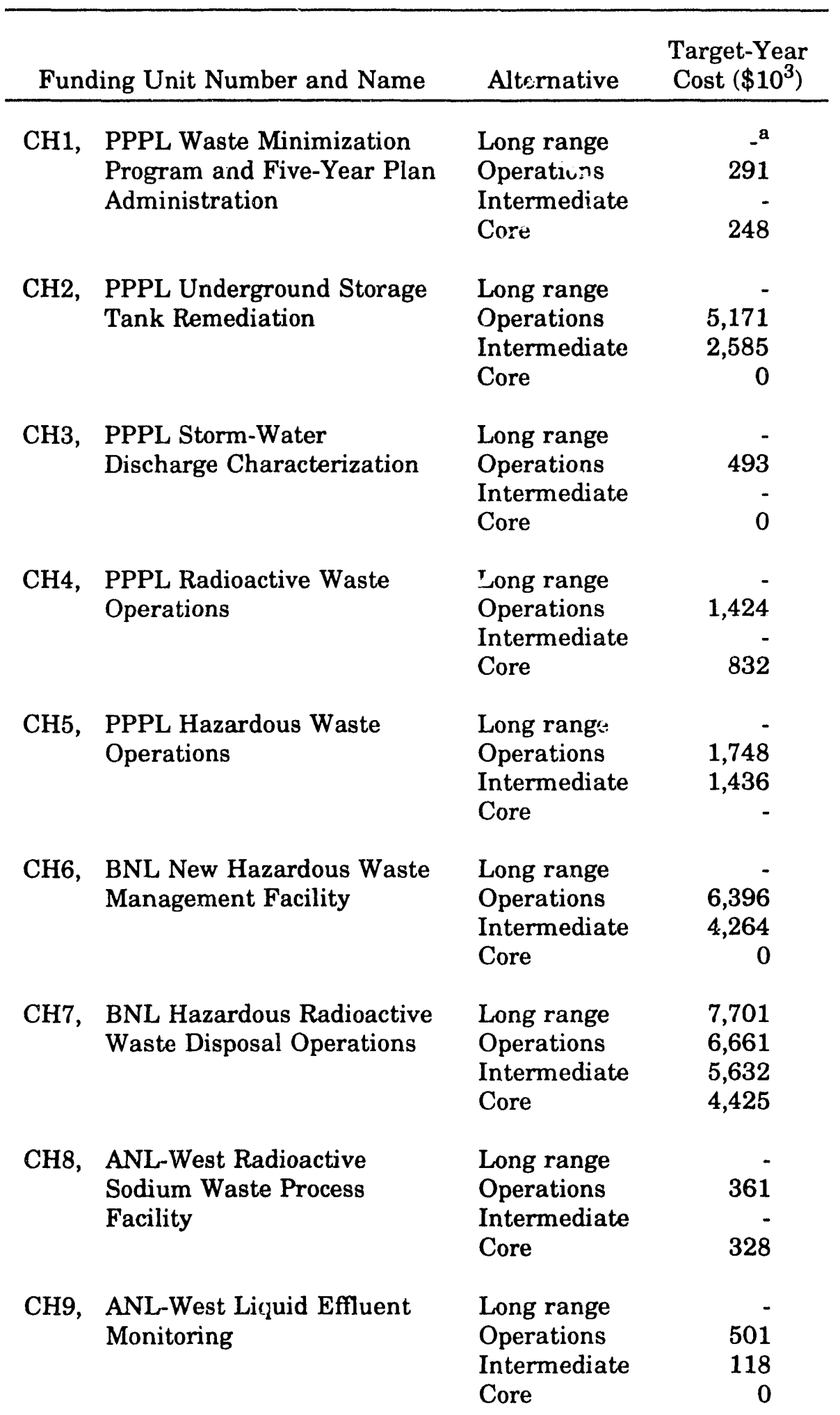


TABLE S.3 (Cont.)

\begin{tabular}{|c|c|c|}
\hline Furding Unit Number and Name & Alternative & $\begin{array}{l}\text { Target-Year } \\
\text { Cost }\left(\$ 10^{3}\right)\end{array}$ \\
\hline \multirow{4}{*}{$\begin{array}{l}\text { CH10, ANL-West Low-Level Waste } \\
\text { Disposal to Radioactive } \\
\text { Waste Management } \\
\text { Complex }\end{array}$} & Long range & - \\
\hline & Operations & 529 \\
\hline & Intermediate & - \\
\hline & Core & 265 \\
\hline \multirow{4}{*}{$\begin{array}{l}\text { CH11, ANL-East Laboratory } \\
\text { Wastewater Treatment } \\
\text { Plant Upgrade }\end{array}$} & Long range & - \\
\hline & Operations & 832 \\
\hline & Intermediate & 416 \\
\hline & Core & 0 \\
\hline \multirow{4}{*}{$\begin{array}{l}\mathrm{CH} 12 \text {, ANL-East Continuity of } \\
\text { Operations }\end{array}$} & Long range & 5,046 \\
\hline & Operations & 2,430 \\
\hline & Intermediate & - \\
\hline & Core & 208 \\
\hline
\end{tabular}

a Indicates that the funding unit manager did not develop this alternative.

The S\&H scale, which measures the risk to the public through air and water pathways, measures the risk within ranges (e.g., 0 to 1 illness). Although no participants experienced major difficulties in estimating the risks on this scale, some participants stated that additional guidance would help produce more consistent results across sites.

The scale that measured waste managed did not include industrial wastewater and did not differentiate among transuranic wastes. Although scoring was not a problem, the scales used in the pilot study do not adequately consider the variability in waste type and should be modified to provide a more meaningful evaluation of the value of waste processing.

The range of the scale that measured possible delays in construction of new facilities was considered to be too small. Some participants thought that the scale should include the effects of permit delays (as well as construction time) and that the scale range should be expanded to three years (from a maximum of one year).

Some proposed activities (e.g., research and development; activities other than treatment, storage, or disposal) did not score as well because the entire value of these activities was not included in the scales used in the pilot study. Other scales could be created to measure these contributions to WM objectives (i.e., add to the RASS objectives for WM). 
TABLE S.4 Funding Units and Alternatives for Albuquerque

\begin{tabular}{|c|c|c|}
\hline Funding Unit Number and Name & Alternative & $\begin{array}{l}\text { Target-Year } \\
\text { Cost }\left(\$ 10^{3}\right)\end{array}$ \\
\hline $\begin{array}{l}\text { AL1, LANL TRU Solid Waste } \\
\text { Storage Operations }\end{array}$ & $\begin{array}{l}\text { Long range } \\
\text { Operations } \\
\text { Intermediate } \\
\text { Core }\end{array}$ & $\begin{array}{r}5,408 \\
3,016 \\
-a \\
2,496\end{array}$ \\
\hline $\begin{array}{l}\text { AL2, LANL Radioactive Liquid } \\
\text { Waste Treatment }\end{array}$ & $\begin{array}{l}\text { Long range } \\
\text { Operations } \\
\text { Intermediate } \\
\text { Core }\end{array}$ & $\begin{array}{r}10,080 \\
8,265 \\
- \\
4,264\end{array}$ \\
\hline $\begin{array}{l}\text { AL3, LANL Low-Level Radioactive } \\
\text { Waste Disposal }\end{array}$ & $\begin{array}{l}\text { Long range } \\
\text { Operations } \\
\text { Intermediate } \\
\text { Core }\end{array}$ & $\begin{array}{r}11,066 \\
6,635 \\
- \\
5,304\end{array}$ \\
\hline $\begin{array}{l}\text { AL4, KCP Replacement of } \\
\text { Industrial Piping }\end{array}$ & $\begin{array}{l}\text { Long range } \\
\text { Operations } \\
\text { Intermediate } \\
\text { Core }\end{array}$ & $\begin{array}{r}2,600 \\
- \\
0 \\
0\end{array}$ \\
\hline $\begin{array}{l}\text { AL5, KCP Modification of } \\
\text { Demolition Lot }\end{array}$ & $\begin{array}{l}\text { Long range } \\
\text { Operations } \\
\text { Intermediate } \\
\text { Core }\end{array}$ & $\begin{array}{r}1,144 \\
- \\
0 \\
0\end{array}$ \\
\hline $\begin{array}{l}\text { AL6, KCP Facility Operations and } \\
\text { Maintenance }\end{array}$ & $\begin{array}{l}\text { Long range } \\
\text { Operations } \\
\text { Intermediate } \\
\text { Core }\end{array}$ & $\begin{array}{r}- \\
6,662 \\
5,580 \\
808\end{array}$ \\
\hline $\begin{array}{l}\text { AL7, Mound Flant Radioactive } \\
\text { Waste Management }\end{array}$ & $\begin{array}{l}\text { Long range } \\
\text { Operations } \\
\text { Intermediate } \\
\text { Core }\end{array}$ & $\begin{array}{r}5,645 \\
5,170 \\
1,786 \\
788\end{array}$ \\
\hline $\begin{array}{l}\text { AL8, Mound Plant Mixed Waste: } \\
\text { Management }\end{array}$ & $\begin{array}{l}\text { Long range } \\
\text { Operations } \\
\text { Intermediate } \\
\text { Core }\end{array}$ & $\begin{array}{r}- \\
1,624 \\
625 \\
140\end{array}$ \\
\hline $\begin{array}{l}\text { AL9, Mound Plant Hazardous } \\
\text { Waste Management }\end{array}$ & $\begin{array}{l}\text { Long range } \\
\text { Operations } \\
\text { Intermediate } \\
\text { Core }\end{array}$ & $\begin{array}{r}11,290 \\
5,726 \\
3,614 \\
572\end{array}$ \\
\hline
\end{tabular}

a Indicates that the funding unit manager did not develop this alternative. 


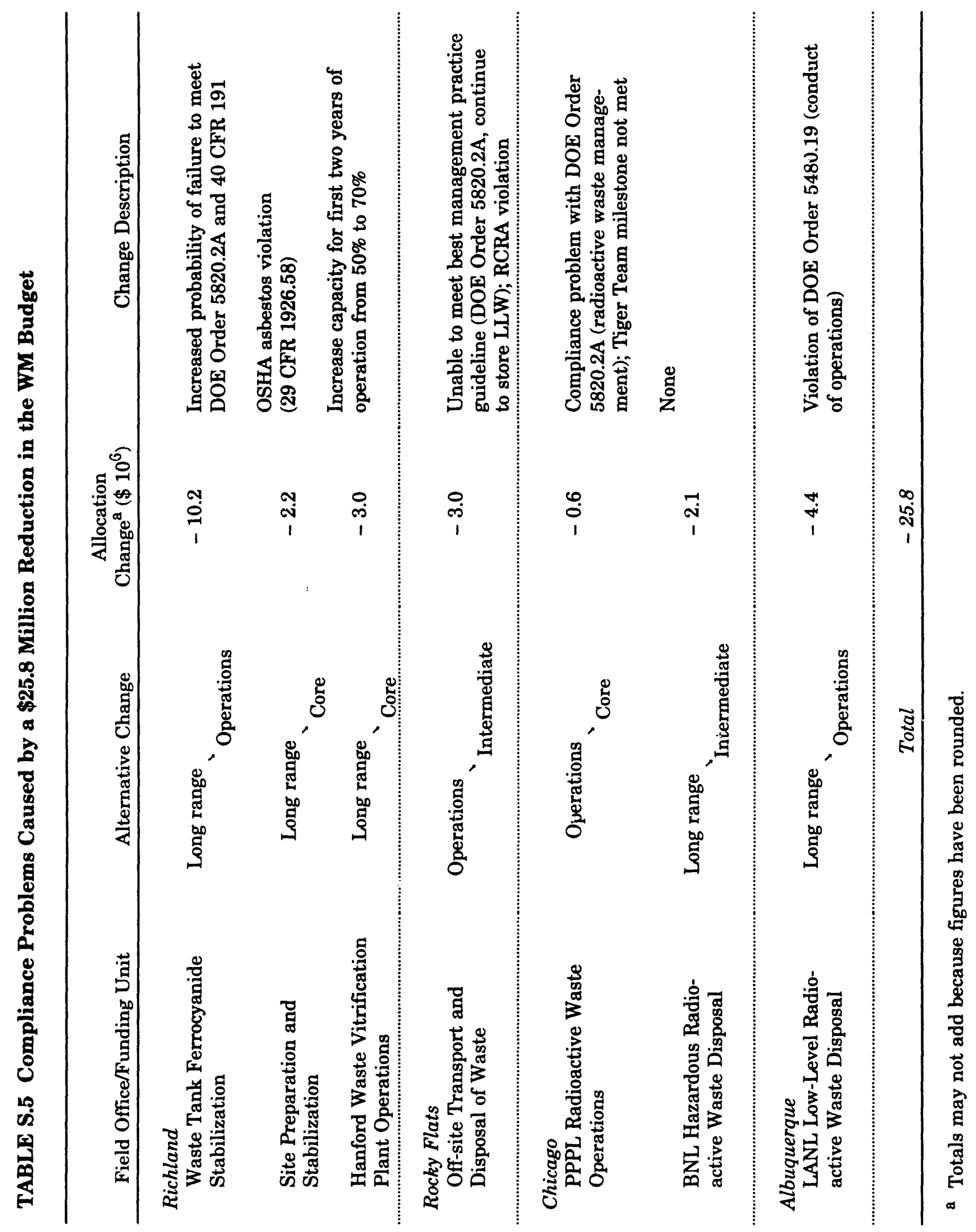


- Objective: Provide an opportunity for the DOE FO/HQ Working Group, the TRG, and external parties to observe the mechanics of the proposed system.

Outcome: Representatives of four DOE field offices participated in the pilot study, and one other field office (Oak Ridge) sent an observer to one pilot study. All nonparticipating FO/HQ Working Group members were invited to observe any of the four pilot studies, but attendance was limited, mainly because of scheduling conflicts.

The Richland pilot study included the participation of two individuals with the Congressional Research Service (one is a member of the TRG, and both attended the first national workshop of external parties). They observed the scoring process and the review session held on the last day. Because the scoring at Richland was conducted in small groups, participants were able to observe the scoring judgments directly.

External parties participated in the Richland and Rocky Flats pilot studies. At Richland, external parties participated in an all-day review session the last day of the pilot study. They listened to presentations and commented on the RASS scales, the selection of funding unit alternatives, scoring judgments made by DOE and contractors, and the results from the RASS model. The external participation at Rocky Flats was more interactive. External parties were involved in the Rocky Flats prepilot meeting and the pilot study. Because the Rocky Flats pilot study had only two funding units, the participants observed the mechanics of RASS at a very basic level.

- Objective: Evaluate the availability of quality data and the capability of project managers to make judgments to support RASS implementation.

Outcome: Field office staff and contractors were able to make judgments needed to define funding unit alternatives and to score these alternatives on the scales. Approximately 50 field office staff (four offices) and contractors (nine sites) were involved in the scoring of funding unit alternatives. In addition, several external parties were involved in the scoring at Rocky Flats; they did not experience major difficulties. All scoring was conducted with little pretraining. The first part of each scoring session could be characterized as an on-the-job training session. In the next RASS application, more thorough training should be provided to aid the scorers.

Most scoring was conducted with direct input from the appropriate project manager. In some cases, the project manager had difficulty in determining a quantitative score; ANL staff assisted in developing quantitative judgments. In some cases, detailed quantitative analyses 
were available to support their judgments. However, field office staff, contractors, and external parties who participated in the pilot study stated that additional scoring guidance would improve the consistency of scoring.

- Objective: Determine the level of effort needed by field offices and contractors to work with the system.

Outcome: Effort to score funding units varied considerably. A brief introductory lecture was the only training given before the scoring sessions. Therefore, each new scorer usually required scme time to understand what information was being requested (on-the-job training). The time required to score a single funding unit varied between one and three hours (including on-the-job training). The longer times usually corresponded to funding units with multiple activities that required more detailed scoring; the shorter times usually were associated with single-activity funding units. If a scorer was scoring more than one Lunding unit, the learning curve was steep, and the time required for scoring the second or third funding unit was less than half that needed for scoring the first funding unit.

The general conclusion is that RASS will require additional effort beyond what is typically required for preparation of activity data sheets. However, if the RASS process can be coordinated with preparation of these sheets, the additional effort required for RASS is reasonable.

- Objective: Identify the type and amount of training and guidance needed to implement the system successfully.

Outcome: Although scoring at all pilot studies proceeded well, all field offices commented that more detailed written guidance and training on methods of scoring activities on the scales would be required for any larger test of RASS because the RASS development team would not be present to assist in scoring. Group training that includes scoring workshops would be useful. The DOE FO/HQ Working Group suggested developing a training film that could be used as an introductory training program for RASS. All three types of training and guidance will be considered for the next RASS test.

- Objective: Determine an appropriate role for the public should RASS prove to be a useful tool.

Outcome: Because any RASS implementation will be integrated with the overall planning activities at a site, the $\overline{\mathrm{O}} \mathrm{\textrm {E }} \mathrm{FO} / \mathrm{HQ}$ Working Group recommended that public involvement in the RASS development program should be consistent with the site's overall public involvement 
program. It is expected that different methods will be used because unique conditions exist at each site.

External parties participated in the pilot study in two different ways. At Richland, the public participaced in an all-day review session held on the last day of the study. Time was available to explore the logic behind the funding unit selection and the scoring judgments. At Rocky Flats, external participation took a more consultative approach. Rocky Flats staff took the lead in developing the funding units and the alternatives and made the initial scoring judgments. These judgments were discussed with external parties, and, in some cases, the scoring was modified. Although this approach was useful and meaningful for Rocky Flats, which has only a handful of funding units, it probably would be time-consuming at a site that has more than 20 funding unit alternatives. Therefore, general guidance on external participation in the RASS process should be issued to the offices, but each site should choose the form of external participation on the basis of their own situation.

\section{S.4 CONCLUSIONS}

RASS was used to examine 96 funding unit alternatives for 33 funding units included in the pilot study. The maximum WM funding request ( $\$ 305.4$ million) is the sum of the highest target-year funding requests for the 33 alternatives (one from each funding unit). Similarly, the minimum WM funding request ( $\$ 115.1$ million) is the sum of the lowest target-year funding requests for the alternatives, generally the core alternatives.

The pilot study results showed that RASS can be a rich source of information to assist DOE's program and budget analysis. RASS was used to identify a number of solutions over the approximately $\$ 200$ million range of WM funding. RASS output provides macroscale (WM-wide) and micro-scale (funding unit by funding unit) information about human $\mathrm{S} \& \mathrm{H}$ impacts, compliance issues, and so on, as a function of total WM budget.

RASS makes it possible for DOE to examine to what degree different perspectives would result in different resource allocations. To test how this important feature would work in practice, eight different perspectives were obtained and included as part of the pilot study.

\section{S.5 FUTURE ISSUES}

The pilot study uncovered a number of important issues that needed further attention, including the following subject areas:

- Characteristics of funding unit alternatives,

- $\mathrm{S} \& \mathrm{H}$ risks, 
- Meeting WM needs,

- Specification of funding units,

- Waste types and values, and

- Constructed scale for compliance.

Several topics were addressed under each of these subject areas. Additional effort will be required to resolve some of the issues before the proposed RASS full-scale test.

\section{S.5.1 Full-Scale Testing}

Following review of the pilot study by the DOE FO/HQ Working Group, the TRG, and external parties, an enhanced RASS design will be prepared for the proposed full-scale test to be conducted in spring/summer 1993. At that time, DOE will decide on the scope and timing of the full-scale test.

\section{S.5.2 Role of External Parties}

Waste Management is considering three potential roles for external parties (regulators, tribal representatives, and other interested parties external to DOE) in the proposed full-scale test of RASS. Field offices, perhaps in consultation with external parties, could choose the role that best suits their circumstances and relationships with external parties:

- Team role: External parties would work with field office staff to assemble and score the funding unit alternatives. The DOE would retain final decision-making responsibility, but external parties would contribute to the preliminary discussions about the RASS process (e.g., formulating funding unit alternatives and scoring them). They would attend all manager-level meetings concerning RASS. They would be trained in RASS at the same time that managers are trained and receive the same guidance.

- Consultative role: Field office staff would do the initial work (i.e., writing a first draft) to assemble and score funding unit alternatives. External parties and field office staff would then work together to adjust or fine-tune the alternatives and scores. External parties would receive separate training and be invited to some of the manager-level meetings concerning RASS (e.g., the pilot study tests in which they were invited to the second or third day of the scoring workshops) 
- Review and comment role: Field office staff would assemble and score the funding unit alternatives without input from external parties. External parties could receive separate training. They would receive the results of the test in reasonably complete written form and provide either written or verbal comments on the funding unit alternatives and scores. Separate from external parties, field office staff would consider the comments and incorporate them, as appropriate, when revising the alternatives and scores. External parties would learn how the comments were considered through either a meeting or a formal written document.

These proposals for public participation will be discussed with external parties at the next national workshop. One topic to explore might be what other conclusions external parties would draw from the pilot study experience. Another topic might be external parties' views of the proposed flexible alternatives for public involvement and their suggestions for alternative roles for regulators, tribal government representatives, and other interested and affected parties.

\section{S.5.3 Implementation}

If RASS is implemented, DOE Headquarters will use the information generated on how well alternatives achieve program objectives to assist in actual program and budget decisions. However, the pilot study results were only used to test the RASS process and were not used for any program or budget decision making. 


\section{INTRODUCTION}

The Resource Allocation Support System (RASS) pilot study was designed to test the practicality of the RASS design concept. This study involved testing the design and basic concepts of RASS, testing the RASS process and scoring procedure, and evaluating the RASS allocation process and its results. This report summarizes the development process and the combined results of pilot studies conducted at the Richland (RL), Rocky Flats (RF), Chicago (CH), and Albuquerque (AL) field offices of the U.S. Department of Energy (DOE) from June to September 1992 (Absil et al. 1992; Kier et al. 1992a,b,c).

RASS is a decision-aiding system being developed to assist DOE's Office of Waste Management (WM, also known as EM-30) in making better informed program and budget decisions. RASS analyzes alternatives in terms of projected costs and estimated benefits. Benefits include considerations such as meeting the requirements of environmental or safety regulations and other compliance concerns.

The proposal to develop RASS resulted from two needs:

- To provide WM decision makers with better information about WM program and budget proposals, and

- To assure Congress that WM funds are well spent.

Several questions are generated from these needs. For example, how well do the proposals address the protection of the safety and health $(\mathrm{S} \& \mathrm{H})$ of workers and the public, and how well do the proposals meet WM's objectives, including compliance with laws, treaties, regulations, and agreements (e.g., tri-party agreements, interagency agreements)? To better answer these and similar questions, WM wants to generate insights about proposals that are forwarded to Headquarters for consideration.

Waste Management's mission is to permanently protect people and the environmeıt from the hazards of DOE wastes by providing an effective and efficient system that minimizes, treats, stores, and disposes of DOE waste as soon as possible. Wastes managed by WM include the following:

- High-level waste (HLW). HLW is highly radioactive waste material that results from reprocessing spent nuclear fuel. This material contains a combination of transuranic waste and fission products in concentrations that require permanent isolation. It also includes liquid waste produced directly in reprocessing operations and any solid waste derived from the liquid.

- Low-level waste ( $L L W$ ). LLW is radioactive waste not classified as highlevel waste, transuranic waste, spent nuclear fuel, or by-product material. 
- Transuranic (TRU) waste. TRU waste is waste contaminated with alpha-emitting transuranium nuclides with half-lives greater than 20 years and concentrations greater than $100 \mathrm{nCi} / \mathrm{g}$ of waste.

- Sanitary waste. Sanitary waste (e.g., garbage) is generated by normal housekeeping activities and is not hazardous or radioactive. This waste is disposed of in sanitary landfills and includes liquids treated in sewage treatment plants.

- Hazardous waste. As defined in the 1976 Resource Conservation and Recovery Act (RCRA), hazardous waste is a solid waste or combination of solid waste that, because of its quantity, its concentration, or its physical, chemical, or infectious characteristics, may cause or significantly contribute to an increase in mortality or an increase in serious, irreversible, or incapacitating reversible illness or pose a substantial present or potential hazard to human health or the environment when improperly treated, stored, transported, or disposed of, or otherwise managed.

- Mixed waste. Mixed waste contains both radioactive and hazardous components, as defined by the Atomic Energy Act and RCRA, respectively.

As indicated in Figure 1, WM encompasses ongoing activities throughout DOE's operating complex. Major sources of wastes include nuclear energy programs, energy research programs, and defense programs, as well as other programs within EM. Waste Management activities involve alternative ways of minimizing, treating, storing, and disposing of a variety of wastes that exist in several forms. Treatment facilities process waste to reduce the amount and toxicity of radioactive and hazardous chemical materials and to make the waste safer to handle. Waste storage is an interim measure used to retain and monitor waste in a retrievable manner pending final disposal. Waste Management also develops and implements the technologies and processes used to prepare DOE waste for permanent disposal. Waste minimization activities are designed to avoid the generation of radioactive, hazardous, mixed, and solid sanitary waste as well as to reduce waste volume and concentration.

The RASS development process is proceeding with input from three primary groups (Figure 2):

- DOE Field Office/Headquarters (FO/HQ) Working Group. This group consists of DOE field office and Headquarters staff who will be the primary users of RASS. This group provides a practical perspective on reasonable and acceptable characteristics for RASS. Meetings with this group were held in July and December 1991 and in February (subgroup on RASS measurement scales), May, and November 1992. 


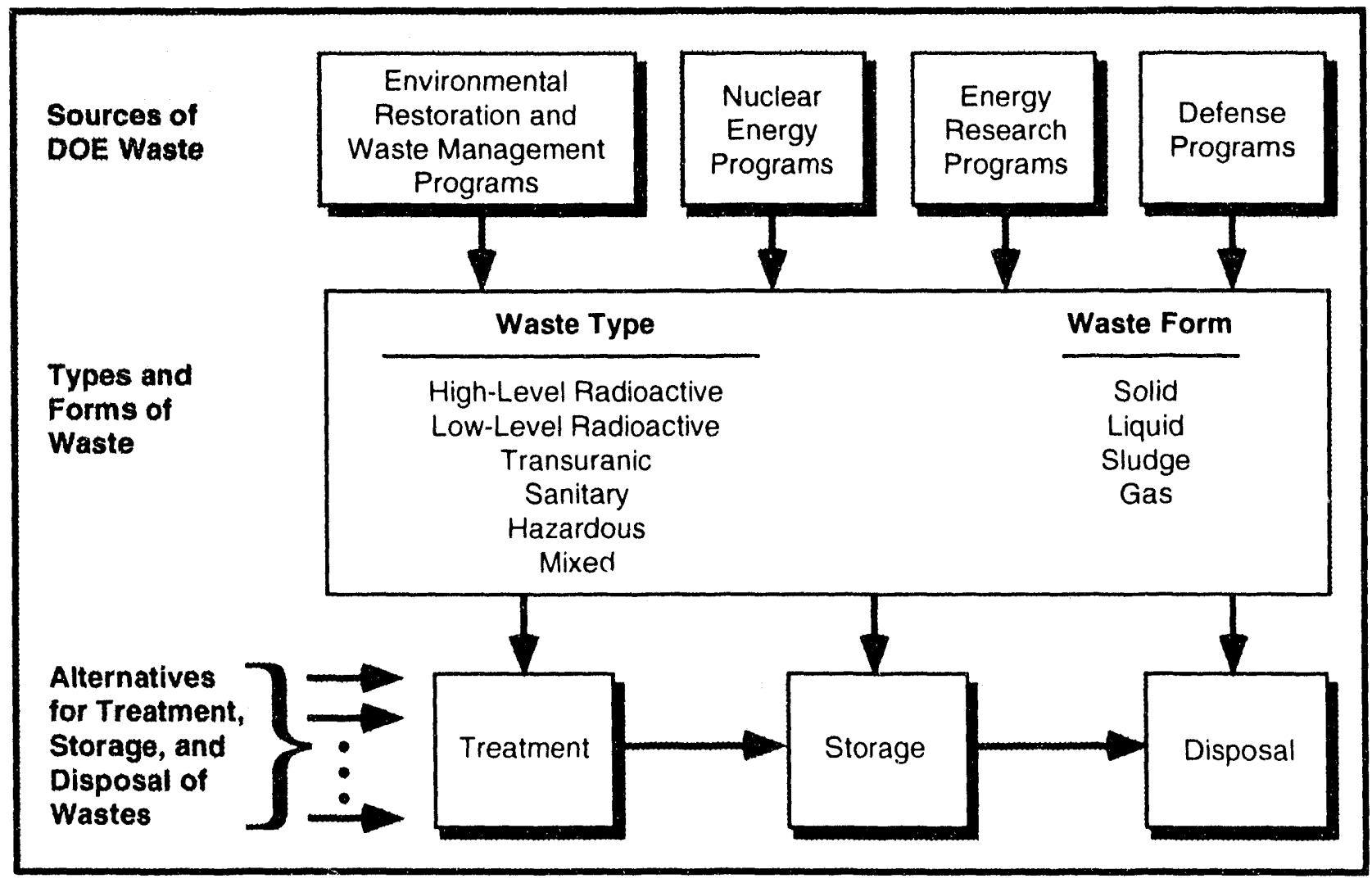

FIGURE 1 Sources, Types, Forms, and Management of DOE Waste

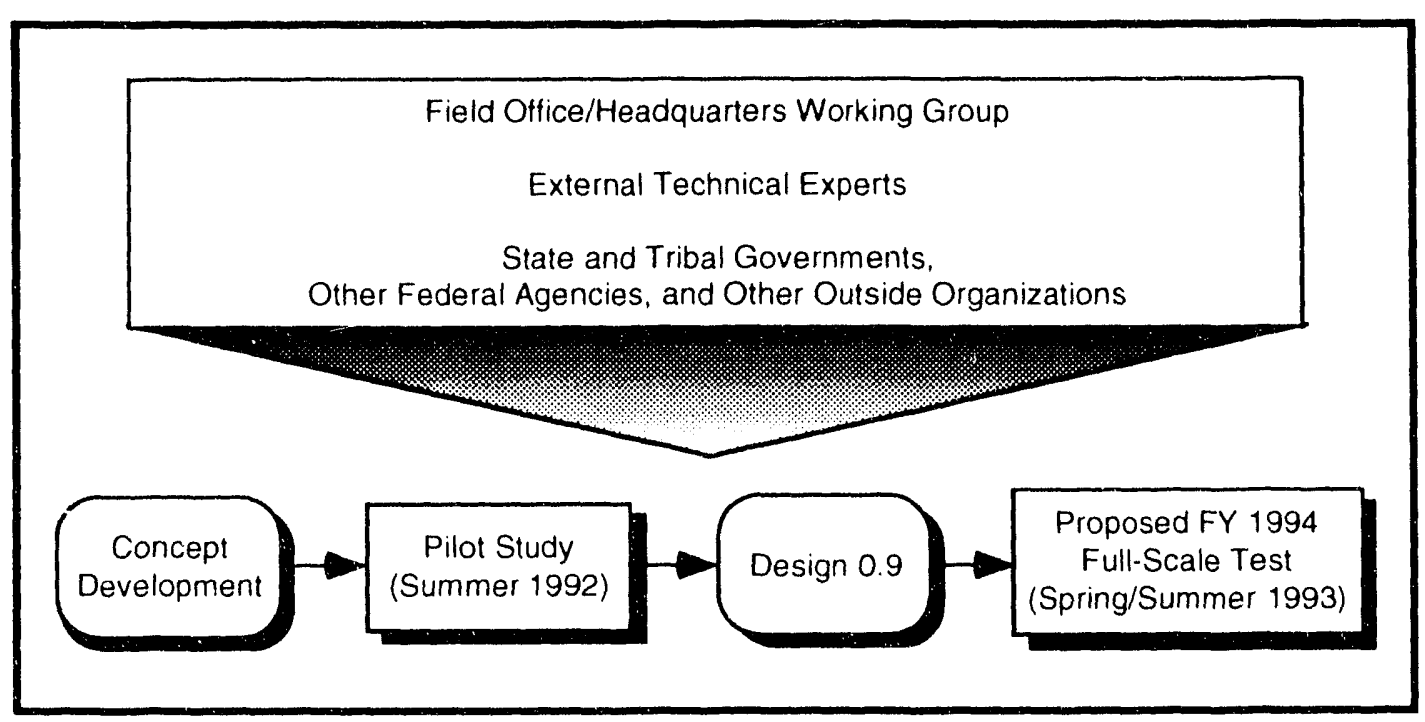

FIGURE 2 Groups and Organizations Involved in the RASS Development Process 
- Technical Review Group (TRG). This group of experts in decision analysis, operations research, risk estimation, and program planning helps ensure that RASS is technically sound and credible. Meetings were held with the TRG in December 1991 and December 1992 to review RASS and its development process. Members of the TRG reviewed relevant materials between those meetings.

- External parties. Interviews were conducted with more than 80 persons in summer/fall 1991 as initial concepts for RASS were studied. Thase individuals represented more than 50 organizations external to DOE. Some of these individuals participated in a national workshop in January 1992 to discuss the RASS draft design concept (Buehring, Whitfield, and Wolsko 1992). External parties participated in the Richland and Rocky Flats pilot studies (Section 4.2). A second national workshop, scheduled for March 1993, will examine the results of the pilot study.

Four major events in RASS development are shown in Figure 2. Development of the RASS design concept (January 1992) was followed by construction (spring 1992) of a limited version of RASS for testing in the pilot study (June-September 1992). Once the three groups have reviewed the results of the pilot study, an enhanced RASS design (labeled "Design 0.9" in Figure 2 to indicate that further improvements are likely) will be prepared for the proposed fiscal year (FY) 1994 full-scale test to be conducted in spring/summer 1993. The proposed full-scale test would involve all WM field offices and all WM work proposals.

To describe how RASS operates, it is necessary to define three related terms: activity, funding unit, and funding unit alternative. An activity is a specific proposal for work, such as new construction; an upgrade to an existing facility; routine maintenance; treatment, storage, or disposal of waste; or monitoring of the environment. A funding unit, the decision unit in RASS, is a logical grouping of activities consistent with WM program planning. A funding unit may be an installation, a facility, or a major activity. A funding unit alternative is a funding unit with specified levels of funding for each included activity. The activity data sheet (ADS), the WM program planning and budgeting document currently in use, generally summarizes proposed activities for one funding unit but sometimes addresses more than one funding unit.

For example, the $\mathrm{K}$ Basins at Hanford were considered as one funding unit in the RASS pilot study. The K-East and K-West basins are used to store irradiated nuclear fuel. The Hanford $\mathrm{K}$ Basin funding unit consisted of five activities (most funding units in the RASS pilot study had fewer than five activities):

- Ensure continuity of operations (including maintenance and surveillance),

- Upgrade basins (including encapsulation and repackaging), 
- Respond to regulations (including environmental oversight and sampling and monitoring),

- Extend the life of the basins (including security and seismic equipment), and

- Construct a water supply system (new water plant to save on operation and maintenance costs and to conserve energy).

Three funding unit alternatives were analyzed for this funding unit. The alteinative with the highest funding request addressed the needs of all five activities. The alternative with the lowest funding request achieved minimal or no progress on the five activities. The third alternative was between the high and low alternatives in funding request and in achievement of needed work.

Each funding unit alternative included in the pilot study was scored (rated) with respect to RASS objectives for $\mathrm{WM}^{1}$ that were specified as part of DOE's initial guidance. For the RASS pilot study, these objectives for WM addressed the following issues:

- Compliance with regulations, orders, treaties, and agreements;

- Near-term risks to human safety and health;

- DOE waste management needs; and

- WM system costs.

Other potential RASS objectives for WM were identified during discussions with the three groups described earlier. Several of these objectives are being studied and may be added to RASS for the proposed full-scale test.

If RASS is implemented, DOE Headquarters will use the information generated on how well alternatives achieve program objectives to assist in actual program and budget decisions. However, the pilot study results were only used to test the RASS process and were not used for any program or budget decision making.

1 RASS objectives for WM refer to statements about what WM wants to achieve. These statements are characterized by a decision context, an object, and a direction of preference. One RASS objective for WM that was included in the pilot study is to minimize near-term risks to human safety and health. With this objective, the decision context is funding WM activities, the object is human S\&H risk, and the direction of preference is less impact. RASS objectives for WM are to be distinguished from the pilot study objectives presented in Section 1.1. 


\subsection{OBJECTIVES OF THE PILOT STUDY}

The pilot study was a practical evaluation to determine whether RASS can be a useful program and budget analysis tool for the WM program. The pilot study had the following specific objectives:

- Determine whether proposed activities can be meaningfully evaluated on the scales developed to score funding unit alternatives for RASS objectives for WM.

- Provide an opportunity for the DOE FO/HQ Working Group, the TRG, and external parties to observe the mechanics of the proposed system.

- Evaluate the availability of quality data and the capability of project managers to make judgments to support RASS implementation.

- Determine the level of effort needed by field offices and contractors to work with the system.

- Identify the type and amount of training and guidance needed to implement the system successfully.

- Determine an appropriate role for the public should RASS prove to be a useful tool.

An assessment of performance with respect to the pilot study objectives is included in Section 5.1 .

The alternatives examined for each funding unit in the pilot study differ in the level of funding allotted to a funding unit. The following funding unit alternatives were defined for the pilot study:

- Core: This alternative has the lowest funding request in the target year. It generally includes funding to maintain equipment or a facility in a safe and ready-to-operate mode but does not provide operating funds. This alternative addresses activities only in the standby mode and may have compliance problems because of the standby status.

- Intermediate: This alternative represents a funding option between the core and operations alternatives.

- Operations: This alternative includes all operating, maintenance, and capital expenses needed to conduct scheduled waste management activities in a safe, efficient manner and achieves compliance to the degree possible with all applicable laws, regulations, agreements, treaties, and DOE orders. 
- Long range: This alternative has the highest funding request in the target year. It includes facility upgrades or new construction. Activities for this alternative include facilities that offer long-range benefits to the waste mar agement system. 'This alternative often cooresponds to the "planning" funding request prepared for the FY 1994 ADS.

Scales have been proposed to determine the degree to which a funding unit alternative meets the four RASS objectives for WM, and data forms with instructions for scoring funding unit $\mathrm{al}^{+} \backslash$ matives have been developed. These are described in Whitfield, Buehring, and Wolsko (1992).

\subsection{REVIEW OF PROCEEDINGS}

The sequence of events varied at each of the four field offices that participated in the RASS pilot studies. The first pilot study was conducted at Chicago, and the others followed in the order shown in Table 1.

Prepilot briefings were held at three of the four participating field offices. Typically, an overview of RASS was presented, and the field office project managers discussed some candidate funding units for the pilot study.

TABLE 1 Sequence of Events at Each Field Office

\begin{tabular}{|c|c|c|c|c|c|c|}
\hline Field Office & $\begin{array}{l}\text { Prepilot } \\
\text { Briefing }\end{array}$ & Day 1 & Day 2 & Day 3 & Day 4 & Day 5 \\
\hline Chicago & Yes & $\begin{array}{l}\text { Introduction }^{a} \\
\text { Funding unit } \\
\text { description }^{c}\end{array}$ & Scoring & Scoring & $\begin{array}{l}\text { ANL } \\
\text { summary }\end{array}$ & $N A^{b}$ \\
\hline Albuquerque & No & $\begin{array}{l}\text { Introduction }{ }^{a} \\
\text { Funding unit } \\
\text { description }\end{array}$ & Scoring & Scoring & $\begin{array}{l}\text { ANL } \\
\text { summary }\end{array}$ & NA \\
\hline Richland & Yes & $\begin{array}{l}\text { Introduction } \\
\text { Funding unit } \\
\text { description }^{c}\end{array}$ & Scoring & Scoring & Scoring & $\begin{array}{l}\text { ANL } \\
\text { summary }\end{array}$ \\
\hline Rocky Flats & Yes & $\begin{array}{l}\text { Introduction }{ }^{a, d} \\
\text { Funding unit } \\
\text { description }^{b, d} \\
\text { Scoring }\end{array}$ & $\begin{array}{l}\text { Scoring } \\
\text { ANL } \\
\text { summary }^{d}\end{array}$ & NA & NA & NA \\
\hline
\end{tabular}

a Overview; Whitfield, Buehring, and Wolsko (1992).

b Not applicable.

c Funding unit descriptions include alternatives (by field office staff and/or contractors).

d External parties were present for the Argonne National Laboratory (ANL) summary. 
The introductory session on the first day of the pilot study was held for participating DOE project managers. The material covered included an overview of how RASS could fit into WM's resource allocation procedures; a definition of activities, funding units, and funding unit alternatives; a discussion of characteristics of core, intermediate, operations, and longrange funding unit alternatives; a discussion of the scales used to rate how well each alternative meets the four RASS objectives for WM; and instructions for completing the RASS data forms.

The project managers then described the funding units to be considered during the pilot study. Argonne National Laboratory (ANL) staff helped project managers define the funding units, define alternatives, and complete the RASS data forms. The number of days required for scoring (rating activities against RASS objectives) depended on the number of funding units defined, the number of funding unit alternatives, and the number of participating project managers. Time required for scoring ranged from 1.5 to 3 days at the four field offices (Table 1).

At Albuquerque, an extended discussion determined whether a core funding level that would not allow a particular type of waste to be handled in compliance with statutory requirements could result in "plant shutdown," either as a management decision to avoid noncompliance or by regulators as a result of noncompliance with enforcement orders. Participants decided that the core alternative should include the possibility of a plant shutdown.

Typically, the site representatives and DOE project managers completed the RASS data forms, and ANL staff entered the data into the RASS computer program. (Stored data are used to produce one form per activity [called an "activity report"] that contains all the information related to that activity.) When all the activity reports for a funding unit were completed, ANL staff members reviewed the reports with the site representatives and DOE project managers to ensure that the completed data forms accurately represented the activity. Errors were corrected, and the revised information was entered into the RASS computer program.

The RASS program was applied to obtain an equivalent-cost figure for each of the funding unit alternatives. The equivalent cost for each funding unit alternative was used by RASS to determine, for different total WM budgets, which set of alternatives (one from each funding unit) best met the RASS objectives for WM.

On the final day, ANL staff members presented tables and graphs that displayed the results of the scoring. Suggestions for RASS were presented for funding unit alternatives at different total field office funding levels. Argonne also presented a tentative list of lessons learned and solicited (and received) additional lessons learned from the participants.

On the final day at Richland, ANL staff, DOE project managers, and site representatives were joined by public participants from Native American tribes and agencies of the states of Washington and Oregon. An overview of the RASS process was presented. It covered material very similar to material presented in the iritial introductory session. 
Funding unit alternatives of interest to these individuals were described, and the scoring process and results of the Richland pilot study were summarized.

At Rocky Flats, external parties participated in the prepilot briefing and in both days of the pilot study. Site representatives described the two funding units, and scoring discussions followed. On the final afternoon, ANL staff presented the results of the pilot study for Rocky Flats as well as for Richland.

\subsection{OUTLINE OF SUBSEQUENT SECTIONS}

Section 2 of this report gives an overview of the RASS concept and the ways in which WM objectives are measured by RASS scores. Section 3 briefly describes the 33 funding units included in the pilot study. Public participation in the pilot study is summarized in Section 4. Results from different perspectives for the combined pilot studies are presented in Section 5. Section 6 lists lessons learned and describes directions for future RASS developments. Section 7 consists of a list of references. 


\section{OVERVIEW OF RASS METHODOLOGY FOR THE PILOT STUDY}

This section provides background information on RASS and describes the scales used in the pilot study to measure the effectiveness of proposed work at WM sites. This background material includes a view of the RASS application (if RASS were to be implemented) and a brief description of the RASS design. A description of the performance scales gives details of the nine measures used in the pilot study.

\subsection{BACKGROUND INFORMATION ON RASS}

RASS is being developed to aid the WM program and budget decision-making process by providing insights into how well a proposed activity would accomplish program objectives. RASS would identify the funding allocation among WM activities at a given total budget that would achieve the greatest benefits for WM. Waste Management has requested that RASS be able to provide insights from different perspectives, e.g., to allow sensitivity analysis with value judgments provided by different people (Figure 3 ). For example, several participants from the three groups (Figure 2) volunteered during the RASS pilot study to test this feature (Section 5.3).

To aid the WM program and budget decision-making process, RASS evaluates alternatives in terms of projected costs and estimated benefits (e.g., S\&H improvements or

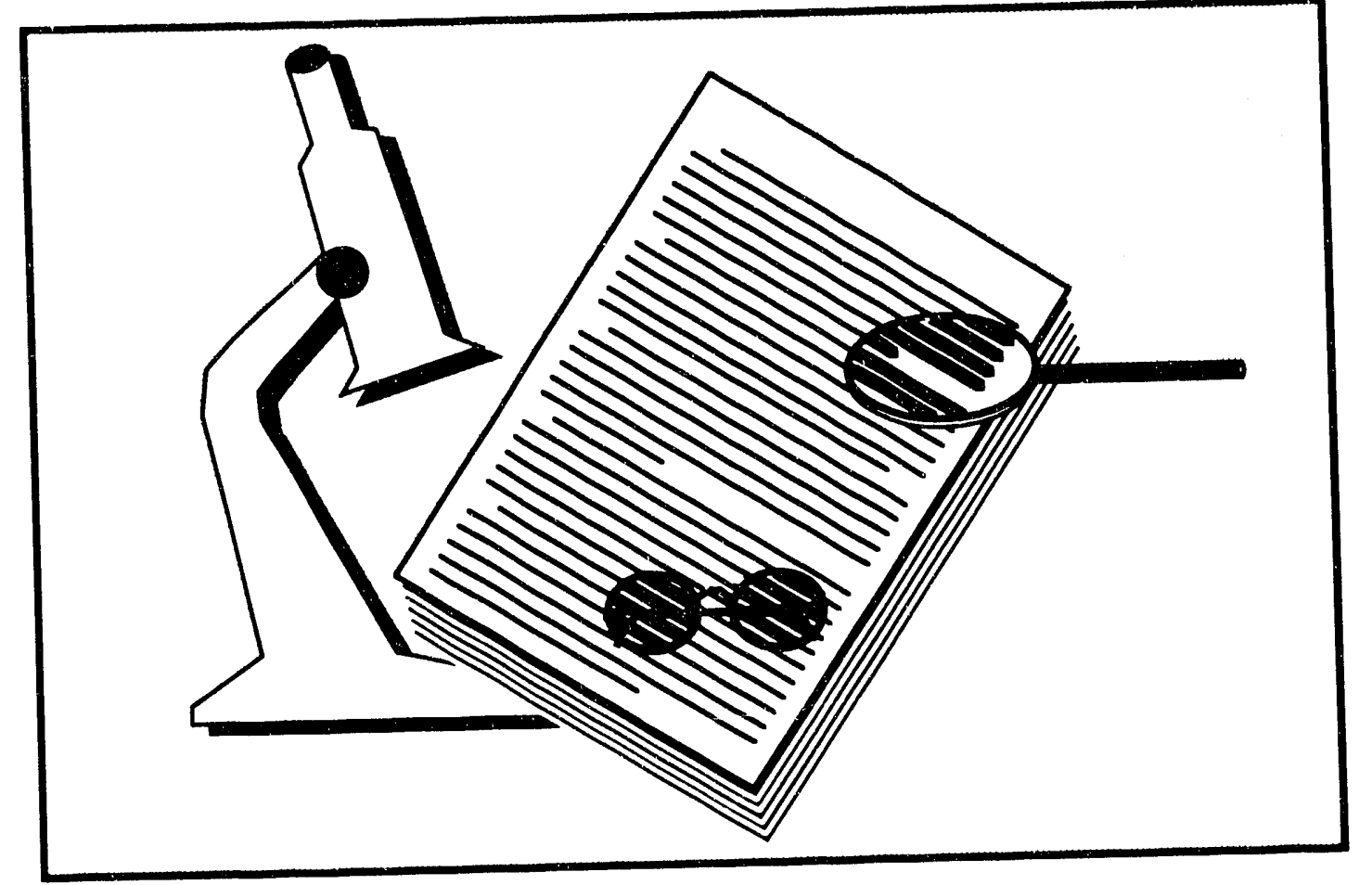

FIGURE 3 Different Perspectives Can Be Used as a Basis for RASS Results 
quantities of waste treated, stored, or disposed). Both Headquarters WM managers and field office personnel will be able to apply RASS to examine, for a specified WM budget, short- and long-term costs while àccounting for benefits.

The following goals were established through discussions with DOE Headquarters staff, DOE field office staff, and external parties:

- RASS should serve as a tool for evaluating resource allocations and for explaining the basis for budget requests. As a result of DOE's current commitment to site cleanup, WM budget requirements are expected to continue to increase in the next several years. As the WM budget grows, funding must be allocated most effectively to address national priorities (Holt, Meltz, and Simpson 1991). RASS should assist in evaluating and justifying ongoing, new, and expanded work.

- RASS should balance short-and long-term costs and benefits such as the reduction of risks to workers and the public and compliance with environmental regulations. The DOE decisions about proposed work often involve the pace and sequence of activities. RASS should provide a mechanism to analyze and compare these factors.

- RASS should be technically credible, understandable, and capable of achieving internal (Headquarters and field office) and external (public) acceptability. The Office of Technology Assessment (1991) has suggested that DOE and other federal agencies take initiatives to enhance the credibility and public acceptability of their decision-making processes for environmental restoration and waste management. RASS must be technically credible and readily convey this credibility. Also, RASS output should assist those individuals involved in making funding recommendations and achieve a degree of acceptability by persons affected by WM funding decisions.

In addition to the RASS goals, and equally important, is the process for its development. The DOE is committed to meaningful involvement of interested and affected parties in the RASS development and implementation process. Public participation has enhanced the RASS development process and the pilot study (Section 4).

\subsubsection{Application of RASS}

The process for evaluation of proposed WM work (Figure 4) begins with the initial budget guidance that DOE Headquarters provides to the field offices. The initial guidance following RASS implementation includes (1) program assumptions (e.g., a description of the meaning of different budget cases used by the field offices to formulate proposed work) and 


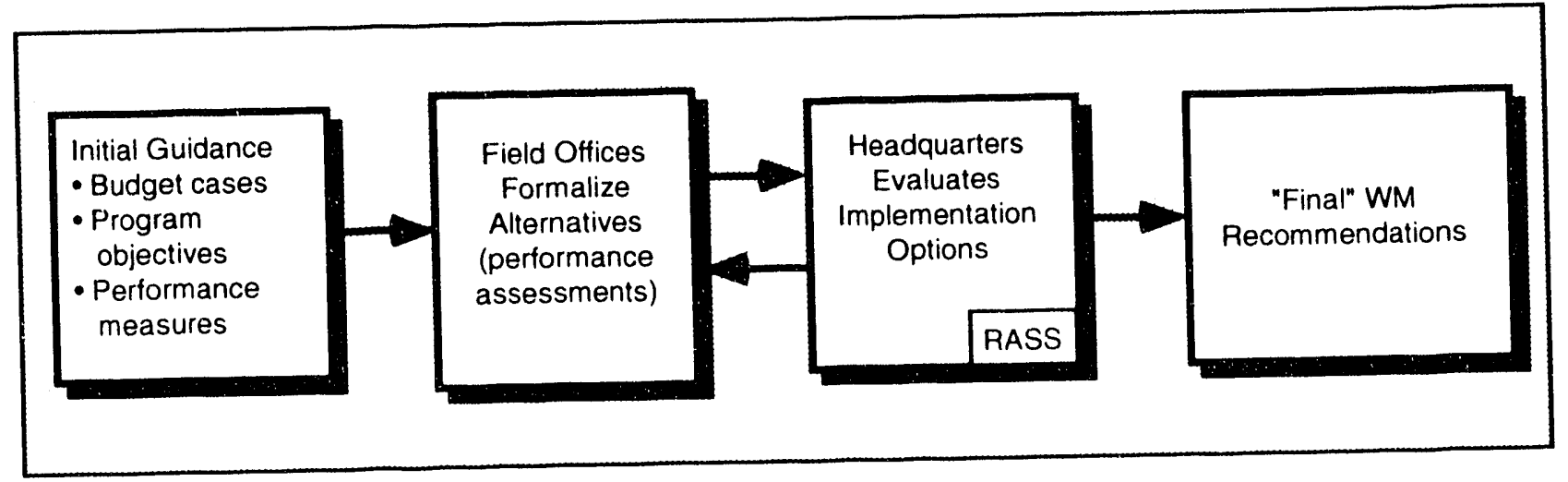

\section{FIGURE 4 Process for Evaluation of Proposed Work}

(2) RASS objectives for WM and performance measures (e.g., effect of proposed work on human safety and health). The field offices then prepare funding unit alternatives that represent sets of activities at several budget levels for a particular funding unit.

For a given WM budget, RASS examines the effect of various assumptions and scenarios on proposed work. A recommended budget allocation from RASS specifies a particular alternative for each funding unit. This allocation is based on the degree to which each alternative satisfies RASS objectives for WM through use of a reference perspective. RASS can also recommend other allocations on the basis of different perspectives and comparisons of such allocations. However, as Figure 4 indicates, if RASS were implemented, it would represent only one component of the analysis of options conducted by Headquarters. (Results of the RASS pilot study were not used to aid budget decisions.)

Each alternative must be scored with respect to the RASS objectives for WM, which are specified as part of the initial guidance. After receiving the scored alternatives for all funding units, DOE Headquarters would apply RASS to examine funding scenarios and to help understand the implications of such scenarios. As the budget process continues, DOE Headquarters would revise the budget guidance (because of interim RASS results, DOE decisions, or budget constraints imposed by guidance received from the Office of Management and Budget [OMB]). New options could be examined by obtaining RASS output for a new budget level. In this way, DOE Headquarters may be able to use RASS results as an aid in making final funding decisions after Congress has appropriated funds; that is, RASS could be used to examine options that reflect congressional priorities. 


\subsubsection{Use of RASS in Program and Budget Decisions}

RASS can be applied at various times during the overall DOE budget process (Figure 5). These applications relate to two fundamentally different types of budget decisions:

- Preparing, explaining, and supporting DOE's budget request for WM funds within DOE and with $O M B$ and Congress. The DOE will use RASS to help evaluare its annual proposed WM budget requests. RASS will provide DOE Headquarters with insights into the relative benefits of the WM activities proposed by the field offices for a given fiscal year. For example, RASS may offer information on compliance, human safety and health, waste managed, and WM system costs. RASS is not intended to produce a single answer to be accepted; rather, RASS's output of relative benefits and costs is expected to prove useful in analyzing the impacts of various funding options.

After submitting its budget request to $\mathrm{OMB}, \mathrm{DOE}$ will use information from RASS to explain, document, and support its budget request in discussions with OMB. RASS could also be used to analyze the implications of the OMB "passback" ${ }^{2}$ and to revise the budget, if necessary, after the OMB budget mark (recommendation) has been decided.

- Analyzing options remaining after congressional appropriations. After Congress has appropriated funds for WM, DOE is responsible for making detailed funding decisions. Application of IASS will help analyze options for these detailed funding decisions among program activities at the various field offices and installations. The purpose of this step is to ensure that final funding decisions reflect congressional priorities and that funds are allocated wisely.

RASS will also assist WM managers in drawing up and analyzing, in advance, different plans in case the congressional appropriation is less than or greater than expected. RASS will help DOE Headquarters managers ( 1 ) see what combinations of activities at various installations will make the best use of available resources and (2) decide how to allocate appropriated funds that are not constrained by congressional action.

2 The initial budget amount decided upon by OMB. 


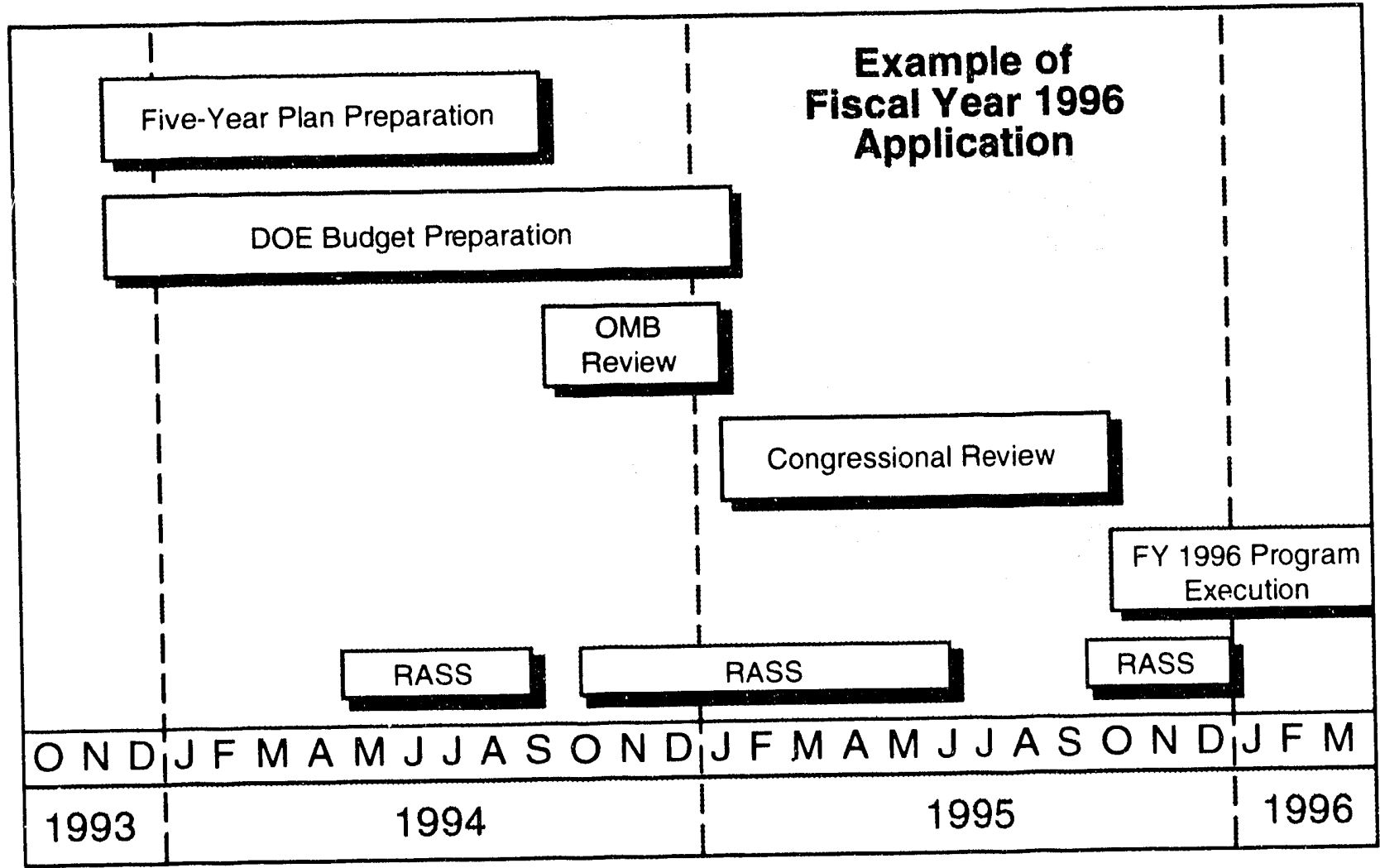

FIGURE 5 Opportunities for RASS Application in the FY 1996 Budget Cycle

RASS will not determine the WM budget, but RASS output will help WM managers examine costs and benefits of funding options at different WM budget levels and with different assumptions. That is, RASS will prove valuable in examining trade-offs among proposed funding unit alternatives for a specific WM budget level.

\subsubsection{Design Overview of RASS}

The RASS approach is an example of "value-focused thinking" (Keeney 1992), which seeks to develop alternative problem solutions that explicitly consider the objectives. Valuefocused thinking first identifies the fundamental objectives of the problem to be addressed. These objectives are then used to guide the program effort, which is to create potential alternatives and evaluate them with respect to the program objectives. The evaluation of alternatives is based on decision analysis (Keeney and Raiffa 1976; Keeney 1982; von Winterfeldt and Edwards 1986), a common-sense approach to problems too complicated for the normal application of intuition (e.g., evaluating electrical generating technologies after rating them with respect to cost, environmental performance, reliability, and fuel supply). 


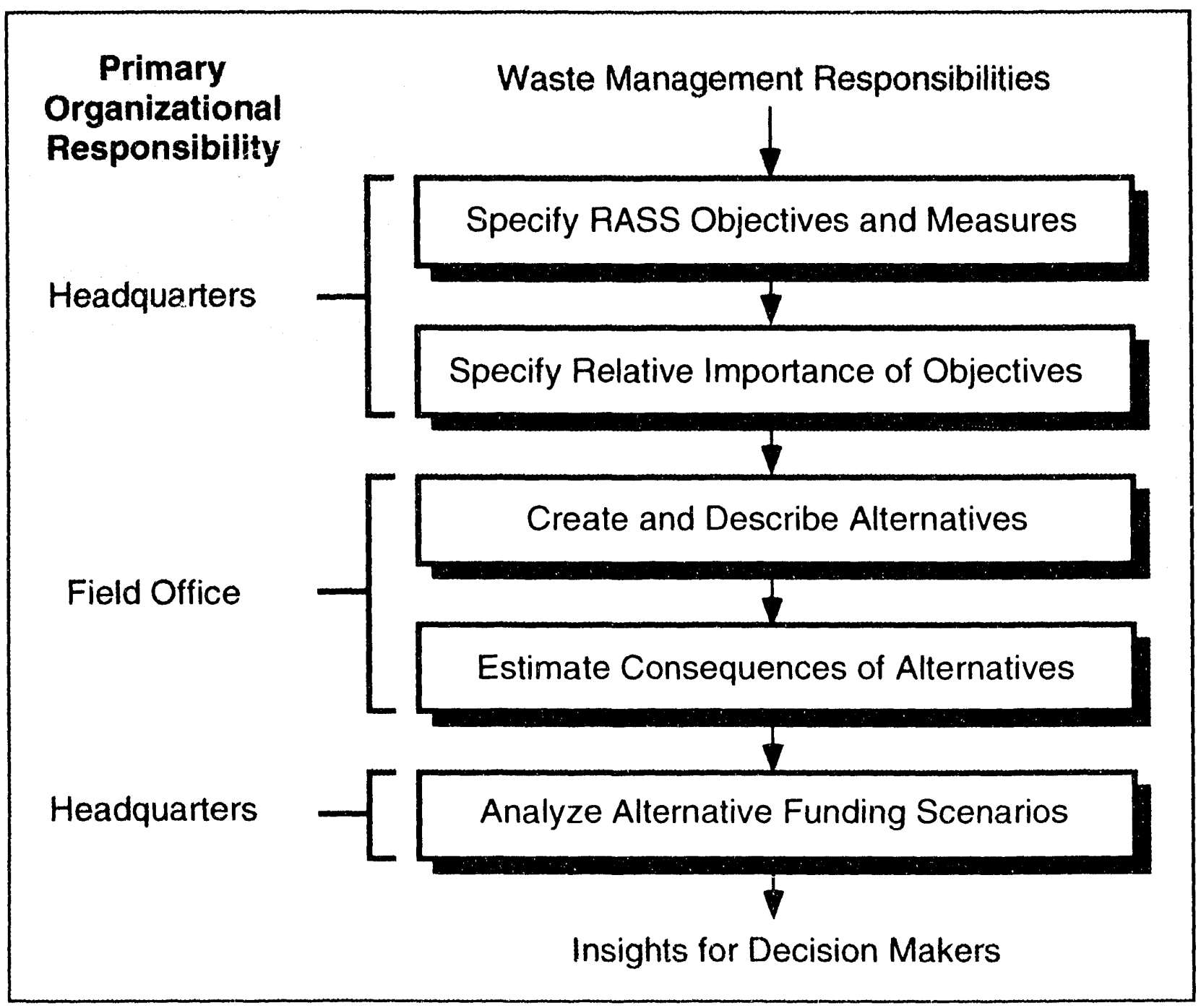

FIGURE 6 Five Stages of the Resource Allocation Support System

A conceptual overview of the five major stages of RASS is presented in Figure 6 . The five major stages are listed below:

- Specify RASS objectives for WM and measures. RASS objectives for WM are the results that WM seeks to achieve in its work. Scales (measures) are developed that indicate the degree to which proposed work satisfies objectives. (The four RASS objectives for WM used for the pilot study are described in detail in Section 2.2.)

- Specify relative importance of objectives. A set of substitution rates (equivalent cost per unit on each scale) specifies the relative importance of different achievement levels on different RASS objectives for WM. An illustrative set was used for the pilot study and is described in Section 5.2 . 
- Create and describe alternatives. Funding unit alternatives are groups of proposed activities. Field offices prepare several alternatives (up to four in the pilot study) for each funding unit. Section 3 describes the funding unit alternatives used in the pilot study.

- Estimate consequences of alternatives. It is necessary to estimate the degree to which alternatives will satisfy objectives. Specific scales are used to rate each funding unit alternative.

- Analyze alternative funding scenarios. Funds can be allocated in many ways; RASS measures the degree to which each allocation satisfies RASS objectives for WM. Section 5.2 summarizes pilot study results for a number of WM budgets. Obtaining improvement on one objcctive often requires settling for less on another objective. This trade-off is demonstrated in Section 5.2 and, for different perspectives, in Section 5.3 .

As stated earlier, RASS addresses WM responsibilities to treat, store, and dispose of many kinds of waste. Headquarters directs the overall operation, and the field offices carry out day-to-day management of treatment, storage, and disposal operations. Figure 6 indicates that Headquarters and field office staff are responsible for different stages of RASS. However, significant interaction between Headquarters and field office personnel is needed at all stages. Headquarters personnel are responsible for specifying RASS objectives for WM, scales, and the relative importance of objectives. However, in the pilot study, significant input was obtained from the field offices, the TRG, and external parties. Field office staff are responsible for creating, describing, and estimating the consequences of alternative sets of activities. Headquarters personnel have primary responsibility for using this information to analyze alternative funding scenarios.

Section 2.2 describes the RASS objectives for WM and scales defined for use in the pilot study. Further information on the RASS concept can be found in Buehring, Whitfield, and Wolsko (1992).

\subsection{RASS OBJECTIVES FOR WM AND SCALES USED IN THE PILOT STUDY}

A critical element of RASS is a set of objectives and supporting measurement scales. The scales are used to measure the effectiveness of work proposed at WM sites. The four RASS objectives for WM included in the pilot study address the following issues:

- Compliance with regulations, orders, treaties, and agreements;

- Near-term risks to human safety and health;

- DOE waste management needs; and

- WM system costs. 
This set of RASS objectives for WM is the result of discussions with DOE Headquarters and field office staff, members of the TRG, and external parties. Additions or modifications to the set of objectives will be investirated should WM proceed with a full-scale test. Several additional candidate objectives have been proposed. The four objectives used in the pilot study were selected because they were considered to be important; also, only four objectives were used in the pilot study in an attempt to keep RASS from being unduly complicated at this early stage of development.

Nine scales were defined to measure performance with respect to the four RASS objectives for WM listed above. Compliance for proposed WM work and WM system cost are each measured on a single scale (scales 1 and 9, respectively). Safety and health impacts are measured by four separate scales (scales 2-5), and waste managed has three scales of performance (scales 6-8). The nine scales are:

1. Compliance - A scale comprised of categories that indicate the "state of compliance" that may result from proposed expenditures in a given year.

2. Morbidity and mortality for the public (air, groundwater, or surfacewater exposure pathways) - Morbidity is converted to equivalent mortality. Estimates include radiation and chemical risks to humans from exposures through air, groundwater, or surface-water pathways.

3. Morbidity and mortality for the public (transportation accidents) Separate calculations that account for risks due to transporting wastes off-site.

4. Morbidity and mortality for workers - Calculations for workers, including risks due to construction and operations activities.

5. Safety program expenditures - The present value of funds, beyond those required by laws or agreements, to be used for programs designed to reduce $\mathrm{S} \& \mathrm{H}$ risks.

6. Capacity/throughput - An estimate of the amount of waste to be treated, stored, transported, or disposed. Although WM's primary activities involve high-level, low-level, transuranic, sanitary, hazardous, and mixed wastes, RASS allows for other types of activities.

7. New capacity status - A measure of the schedule status for new construction activities (e.g., for new treatment, storage, or disposal facilities). The scale includes upgrades to existing facilities and equipment.

8. Five-Year Plan milestones met - An account of performance with respect to meeting Headquarters-tracked Five-Year Plan milestones. 
9. Waste Management system costs - The present value of budget requests, system cost savings, and system cost penalties (e.g., fines).

Sections 2.2.1-2.2.4 describe the nine measurement scales defined for the four RASS objectives to be used in the RASS pilot study. Each section is divided into subsections that discuss (1) background and definitions and (2) general instructions. The first subsection provides information that pilot study participants should consider before they prepare detailed data. The second subsection describes the data form for the RASS pilot study. The actual form and field-by-field instructions are included in Appendix A.

\subsubsection{Compliance}

\subsubsection{Background and Definitions}

The compliance scale is a constructed scale that includes "levels" of compliance that generally range from "compliance with all laws (federal, state, or local), treaties, agreements, and DOE orders," to "conditions that lead to shutdown of certain operations." The compliance scale has eight levels that indicate different types of situations and consequences of noncompliance. If multiple levels apply, or if different compliance issues apply for the same level, each compliance issue is noted.

Table 2 summarizes this scale. Starting with level A, esch succeeding compliance level indicates a more serious problem than indicated by the previous level. Thus, level $\mathrm{H}$ is considered the most serious compliance level. The DOE FO/HQ Working Group determined the relative importance of several levels at a group scoring session. The results were circulated to interested external parties for comment.

This scale captures the importance of achieving compliance. Proposals for future work that result in serious compliance issues are normally not expected or encouraged. That is, most proposed work is expected to result in level $\mathbf{A}$ (full compliance). In many situations, several ways, with different costs and other consequences, are available for bringing WM activities into compliance. However, under severe budgetary restrictions, one or more alternatives may be available for some funding units that do not achieve full compliance. Also, some funding units may be unable to achieve level A compliance in FY 1994 because of schedule delays that have occurred.

\subsubsection{General Instructions}

Field office staff determined the level of compliance for each year (time horizon of one or more years) of every activity included in the pilot study. In cases where more than one compliance issue was present, all levels and issues were noted on the data form 
TABLE 2 Constructed Scale for Compliance

\begin{tabular}{cl}
\hline Level & \multicolumn{1}{c}{ Description } \\
\hline A & Full compliance \\
B & $\begin{array}{l}\text { Nonconformity with a DOE reference standard or other established } \\
\text { "good practice" guidance }\end{array}$ \\
C & Delay in meeting a Tiger Team milestone \\
D & $\begin{array}{l}\text { Violation of a standard that is mandatory under DOE policy or a } \\
\text { provision of a DOE order involving a standard that is mandatory under } \\
\text { a DOE policy }\end{array}$ \\
E & $\begin{array}{l}\text { Request for an accommodation in complying with a statutory } \\
\text { requirement that leads to a negotiated agreement for a compliance } \\
\text { schedule }\end{array}$ \\
F & $\begin{array}{l}\text { Dispute in a Tri-Party Agreement that leads to work stoppage } \\
\text { G }\end{array} \quad \begin{array}{l}\text { Dispute in a Tri-Party Agreement or Native American Treaty that } \\
\text { leads to litigation }\end{array}$ \\
H & $\begin{array}{l}\text { Request for an accommodation in complying with a statutory } \\
\text { requirement that is refused and leads to a shutdown of certain } \\
\text { operations }\end{array}$ \\
\hline
\end{tabular}

(Appendix A). Estimators of compliance levels used probabilities in some cases to represent uncertain outcomes (e.g., a 75\% chance of level A and a 25\% chance of level E).

\subsubsection{Safety and Health Impacts}

\subsubsection{Background and Definitions}

As illustrated in Figure 7, the S\&H objective considers impacts on both workers and the public. Support and administrative personnel are not included among the workers. Both safety and health require, among other things, data that lead to estimates of morbidity (e.g., sickness, injury) and mortality.

RASS considers two factors that affect worker safety and health:

- "Exposures" that lead to negative health effects (morbidity or mortality), and

- Mitigation measures, such as worker training, that minimize exposures and thereby minimize the health effect. 


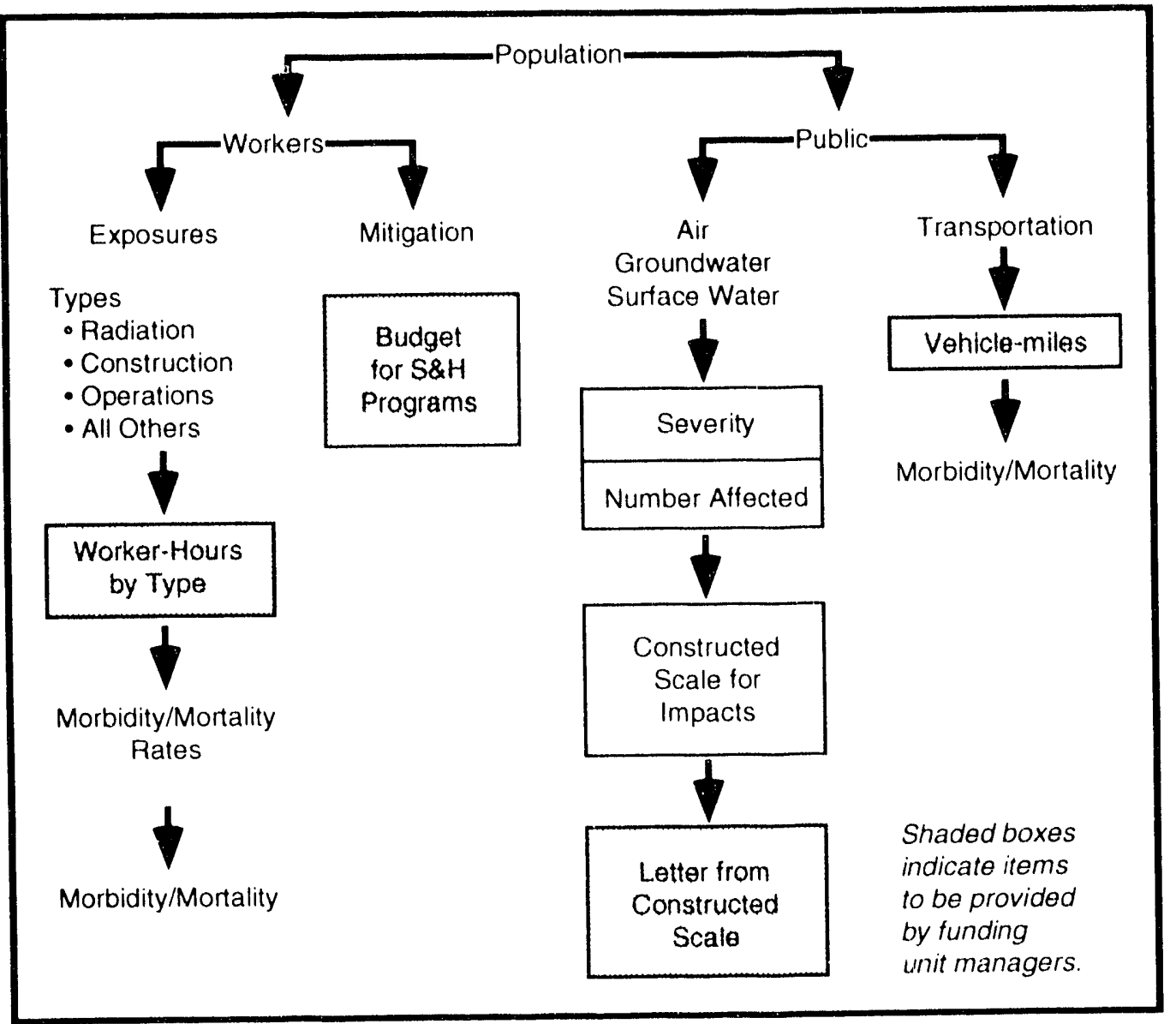

\section{FIGURE 7 Safety and Health Considerations}

Workers may be "exposed" to radiation, hazardous materials, ${ }^{3}$ or routine construction or operations activities that may lead to sickness or injury. Some work environments may involve more than one type of exposure. For the RASS pilot study, the technical project managers and field office staff estimated, for each activity, worker-hours for activities involving radiation exposure, construction, and operations. RASS used factors obtained from the literature to estimate morbidity and mortality for each type of activity.

To account for the benefits of earmarking funds for mitigation measures (e.g., worker training and S\&H programs beyond that required for compliance), technical project managers and fiald office staff were requested to specify the budget set aside for such programs. RASS used these estimates to give credit through a constructed scale.

3 Worker exposure to hazardous materials was not included in the RASS pilot study but would be included in the proposed full-scale test. 
While it is anticipated that most WM activities will not affect the public, RASS must evaluate the safety and health of persons who could be affected by a WM activity. Public S\&H impacts result from

- Accidents (associated with transport of wastes) or

- Exposures to chemicals or radiation through air, groundwater, or surface-water exposure pathways.

To determine transport-related impacts, technical project managers and field office staff estimated the number of vehicle-miles required for shipping waste. From these estimates, RASS used accident rates for routine highway accidents (that do not involve radiation releases) to estimate morbidity and n:ortality for public populations.

Because air, groundwater, and surface-water exposure pathways are much more complicated than transport-related impacts, it was necessary to use a constructed scale that included order-of-magnitude estimates of the number of people affected (e.g., 0, 0-1, 1-10, $10-100,>100$ ) and the severity of the effect (e.g., sickness or death). The scale used for the RASS pilot study is shown in Table 3. Level A means "no people affected in any way." Most funding unit alternatives, but not all, were level A alternatives in the pilot study. Levels B-I denote levels of increasing severity, with level I being most severe.

\subsubsection{General Instructions}

To support the information needed for the $\mathrm{S} \& \mathrm{H}$ objective, technical project managers and field office staff provided the following data:

- Worker-hours of exposure for each type of exposure (e.g., radiation, construction, operations);

TABLE 3 Constructed Scale for Public Safety and Health Effects Due to Air and Water Exposure Pathways ${ }^{a}$

\begin{tabular}{ccc}
\hline $\begin{array}{c}\text { Expected Number } \\
\text { of Affected } \\
\text { Individuals }\end{array}$ & \multicolumn{2}{c}{ Severity of Effert } \\
\cline { 2 - 3 } & Sickness & Death \\
\hline 0 & $\mathrm{~A}$ & $\mathrm{~A}$ \\
$>0$ to 1 & $\mathrm{~B}$ & $\mathrm{~F}$ \\
$>1$ to 10 & $\mathrm{C}$ & $\mathrm{G}$ \\
$>10$ to 100 & $\mathrm{D}$ & $\mathrm{H}$ \\
$>100$ & $\mathrm{E}$ & $\mathrm{I}$ \\
\hline
\end{tabular}

a Letters denote levels of severity from low (A) to high (I). 
- Dollar amount of budget earmarked for S\&H programs;

- An estimate from Table 3 (a constructed scale that relates air, groundwater, and surface-water exposures; severity of health effect; and expected number of public affected); and

- Vehicle-miles required for shipping waste.

\subsubsection{Waste Managed}

\subsubsection{Background and Definitions}

The term "waste managed" includes a variety of activities necessary to treat, store, and dispose of waste. Some of these activities are support activities and do not directly involve actual treatment, storage, or disposal (TSD) activities.

Figure 8 indicates three categories of activities used to measure waste managed:

- Providing for new TSD capacity;

- Conducting TSD operations; and

- Meeting Five-Year Plan milestones.

Providing for new TSD capacity involves planning, designing, and constructing new capacity. RASS considers two key aspects when evaluating how well an activity scores in the waste-managed category:

- Scheduled completion date and

- Status of schedule (time behind schedule at each level of funding).

Reference levels are the highest level of capacity/throughput and the earliest completion date for a given funding unit. In general, these levels are associated with the long-range alternative. Reference levels for capacity/throughput and completion date are not necessarily tied to a specific funding unit alternative (i.e., core, intermediate, operations, long range). However, reference levels should be associated with realistic, achievable alternatives.

The significance of schedule status is affected by the scheduled completion date. For example, an estimated delay of 6 months may not be critical for a 7-year project but would be for a 1-year project. Table 4 presents a constructed scale that attempts to capture these considerations. In this scale, level $\mathrm{A}$ is the most desirable level. 


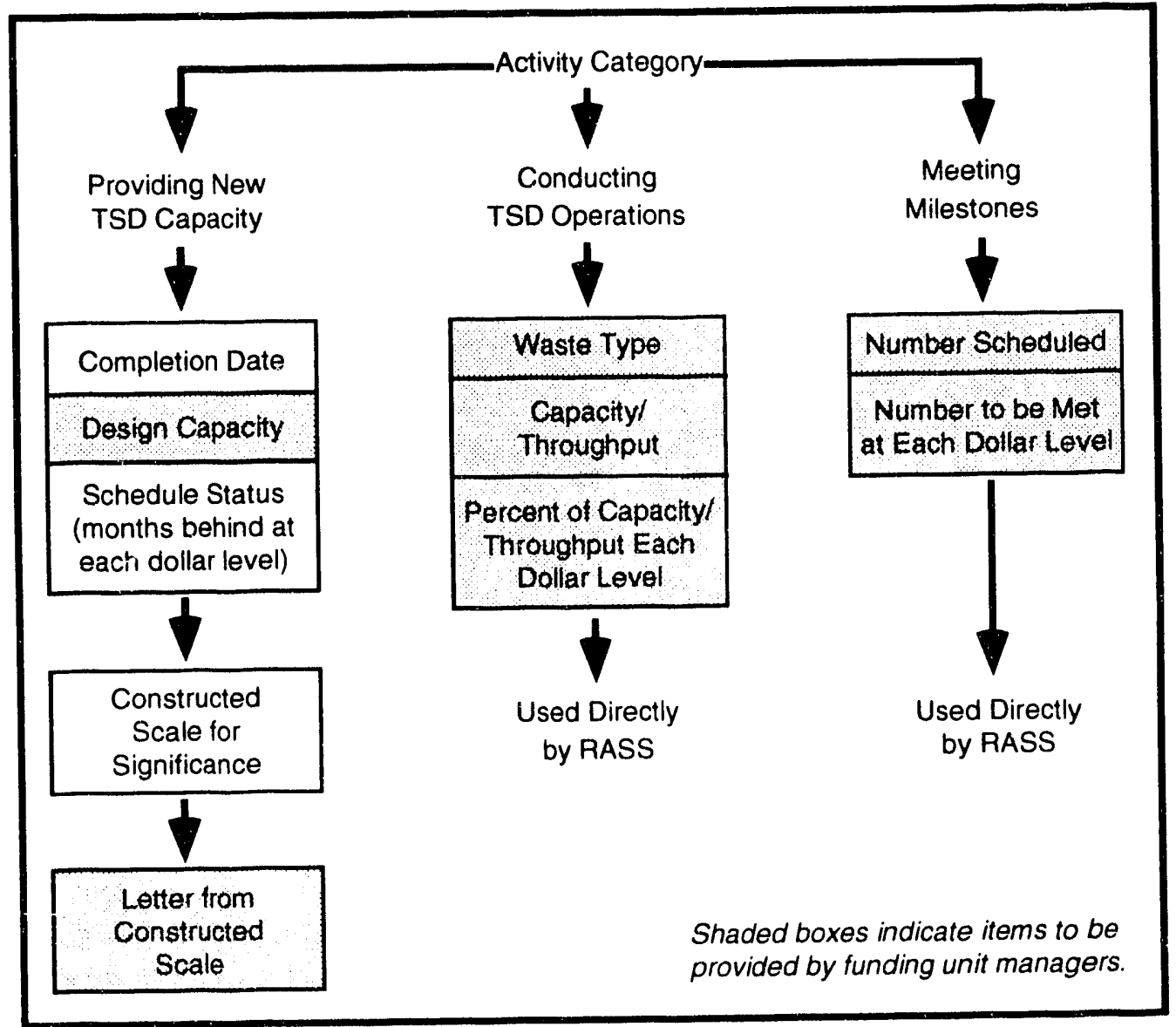

FIGURE 8 Three Categories of Activities Used to Measure Waste Managed

TABLE 4 Constructed Scale for Estimating Schedule Delays in Providing New Treatment, Storage, or Disposal Capacity ${ }^{a}$

\begin{tabular}{ccccc}
\hline \multirow{2}{*}{$\begin{array}{c}\text { Scheduled } \\
\text { Completion } \\
\text { Date }\end{array}$} & \multicolumn{4}{c}{ Delay (months) } \\
\cline { 2 - 5 } & 0 & $1-6$ & $7-12$ & $>12$ \\
\hline Target year & A & D & G & J \\
Out-year 1 & A & C & F & I \\
$>$ Out-year 1 & A & B & E & H \\
\hline
\end{tabular}

a Letters denote levels of severity from low (A) to high (J). 
When a funding unit alternative consists of two or more activities that depend on each other, activities are scored together to specify the likely delay for the funding unit alternative. For such situations, neither activity can claim responsibility for the full delay (this situation would be double-counting).

The TSD operations activity category considers the number of these operations to be conducted by WM. A dollar value is associated with each waste type and activity. Six types of waste were identified in the pilot study: HLW, LLW, TRU, hazardous, mixed, and sanitary. For each type of waste, technical project managers and field office staff estimated the reference level of work (i.e., capacity/throughput needed to meet all commitments) and the percent of reference level that would be met if the requested funding were obtained. As mentioned earlier, the reference level usually is that associated with the long-range alternative.

The meeting milestones category of activities attempts to account for achievements with respect to milestones listed in the Five-Year Plan. The number of relevant milestones listed in the FY 1994-1998 plan was specified for each year (0 for some activities), along with the number that could be met with the indicated funding level.

\subsubsection{General Instructions}

To summarize, technical project managers and field office staff provided the following information:

- Waste type (e.g., HLW, LLW, mixed);

- Type of activity (e.g., treatment, storage, disposal, transportation, other);

- Reference level of capacity/throughput (for treating, storing, or disposing of waste) and unit of measure;

- Percent of capacity/throughput that will be met, given the funding request for this activity;

- Reference completion date;

- A letter score from Table 4 to indicate new capacity status;

- Number of scheduled Five-Year Plan milestones in each year; and

- Number of Five-Year Plan milestones to be met in each year given the funding request for this activity. 


\subsubsection{WM System Costs}

\subsubsection{Background and Definitions}

To discuss WM system costs, it is necessary to define some terms. As used in RASS, WM system costs have two components:

- A target-year WM funding request for an activity is the requested FY 1994 WM funding. Out-year WM funding requests refer to requested WM funding for the four years FY 1995-1998. Far-out-year WM funding request refers to a typical funding request for a year beyond FY 1998 (e.g., for a facility expected to operate for many years).

- System cost savings for an activity are cost reductions that occur at other funding units as a result of improvements at the funding unit "claiming" the cost savings. (For most funding unit alternatives, system cost savings were zero. However, cost penalties incurred [e.g., fines] were listed as negative system cost savings for a few funding unit alternatives.) Cost estimates should be made in current-year dollars. DOE Headquarters provided guidance on factors needed to make these estimates for the pilot study (e.g., escalation rates).

RASS will allocate WM budget dollars to fund target-year budget requests (costs) for funding units in a manner that maximizes the value of the portfolio (the collection of all funding unit alternatives that are funded). Target-year costs are estimated for all activities. Target-year costs for all activities within a funding unit are added to determine the targetyear cost for the funding unit alternative.

\subsubsection{General Instructions}

For purposes of simplicity in the RASS pilot study, rather than specify out-year costs for all out-years over the life of proposed projects, field offices estimated costs for outyears 1-4 (estimated as part of DOE planning [DOE 1991]), as well as one typical far-outyear. The estimate for the typical far-out-year was used to represent all years beyond outyear 4 that are relevant for the activity being scored. Most funding unit alternatives in the pilot study did not need to make estimates for any far-out-years. The number of years to which the typical far-out-year applies is part of the input data. Thus, a project having a life cycle of 15 years that starts in the target year would have entries in the target year, outyears 1-4, and a typical far-out-year that would be assumed to represent the remaining 10 years for the project. Projects completed in the target year would have an entry only in the target year.

Out-year costs are included to capture the out-year implications of a project. For example, construction costs for new construction projects are initially high but may promise 
decreased operating costs in the future (compared with continuing to operate an inefficient facility). The out-year cost measure would thereby capture the benefits of lower operating costs in the future if the new facility is constructed.

When costs for an activity are incurred over a particular period, field offices estimated scores for other RASS scales for the same period. The overall impacts and costs of the proposed work can be considered in RASS by viewing the entire life cycle of the facility. Otherwise, for example, the waste managed for a new facility would be zero if only the first year of construction were considered. If proposed work has no costs or impacts beyond the target year, the RASS scores would simply account for the effects in that year.

Rass computed the present value ${ }^{4}$ of WM system costs to represent the time stream of costs (estimates for the target year and one or more out-years). When costs and impacts are only relevant for the target year, those single values were used. When a time stream existed, the WM system cost used in the RASS pilot study was the present value.

4 A real discount rate was used in the present-value analysis for the cost stream $(10 \% / y r)$. Effects not measured in terms of dollars were not present valued. Instead, a simple sum of impacts was used (equivalent to a discount rate of 0.0). The base year for the present-value of costs is FY 1994 . 


\section{DESCRIPTION OF FUNDING UNIT ALTERNATIVES}

The 33 funding units included in the pilot study are listed by field office and name in Table 5. A national funding unit number is shown for the combined set of 33 funding units, and a local funding unit number is shown for each field office. Richland defined 10 funding units that covered a wide range of activities from grout disposal to building demolitions. Rocky Flats defined 2 funding units that included off-site transport of wastes and operation and upgrade of a liquid waste treatment building. Chicago scored 12 funding units at four sites (Princeton Plasma Physics Laboratory [PPPL], Brookhaven National Laboratory [BNL], ANL-West, and ANL-East) and included a wide range of activities. The Albuquerque pilot study examined 9 funding units at three sites (Los Alamos National Laboratory [LANL], Kansas City Plant [KCP], and Mound Plant).

Each funding unit had up to four alternatives scored against RASS scales. The four alternatives were labeled long range, operations, intermediate, and core (Section 1.1). The 33 funding units had a total of 96 alternatives, yielding an average of nearly three alternatives per funding unit. The sum of one target-year (FY 1994) funding request for each of the 33 funding units was called the total WM budget request in the pilot study (the entire budget profile associated with a funding unit alternative is included in the evaluation). Thus, the sum of the target-year funding requests for the funding unit alternatives with the smallest budget request (generally the core alternative) is the minimum total WM budget request (about $\$ 115$ million). The sum of the target-year funding requests for the funding unit alternatives with the largest budget request (the long-range alternative when it is defined, otherwise the operations alternative) is the maximum total WM budget request (about $\$ 306$ million).

The funding unit alternatives for Richland, Rocky Flats, Chicago, and Albuquerque are summarized in Tables 6-9, respectively. For each funding unit alternative defined, the target-year cost in thousands of dollars for FY 1994 is listed. Thus, three alternatives were defined for KCP Facility Operations and Maintenance (funding unit AL6): the maximum target-year cost is $\$ 6,662,000$ for the operations alternative, and the minimum target-year cost is $\$ 808,000$ for the core alternative.

A table was prepared for each funding unit to illustrate briefly the differences among alternatives for each funding unit. These matrices are included in Appendix B. The table numbers in the appendix correspond to the national funding unit numbers shown in Table 5. Thus, some additional information on alternatives for the BNL Hazardous Radioactive Waste Disposal Operations (national funding unit number 19 from Table 5) can be found in Table B.19. 
TABLE 5 Funding Units for the RASS Pilot Study

\begin{tabular}{|c|c|c|}
\hline \multicolumn{2}{|c|}{$\begin{array}{c}\text { Funding Unit } \\
\text { Number }\end{array}$} & \multirow[b]{2}{*}{ Field Office and Funding Unit Name } \\
\hline Natl. & Local & \\
\hline & & Richland \\
\hline 1 & 1 & Waste Tank Ferrocyanide Stabilization \\
\hline 2 & 2 & Waste Receiving and Processing Module 1 \\
\hline 3 & 3 & New Double-Shell Waste Storage Tanks \\
\hline 4 & 4 & Contact-Handled TRU Waste Retrieval Facility \\
\hline 5 & 5 & Site Preparation and Stabilization \\
\hline 6 & 6 & K Basins \\
\hline 7 & 7 & Hanford Waste Vitrification Plant Operations \\
\hline 8 & 8 & Grout Disposal Program \\
\hline 9 & 9 & Environmental Sampling and Analysis \\
\hline \multirow[t]{2}{*}{10} & 10 & 200-Area Sanitary Sewer \\
\hline & & Rocky Flats \\
\hline 11 & 1 & Off-site Transport and Disposal of Waste \\
\hline \multirow[t]{2}{*}{12} & 2 & Liquid Waste Treatment Operations and Upgrade, Bldg. 374 \\
\hline & & Chicago \\
\hline 13 & 1 & $\begin{array}{l}\text { PPPL Waste Minimization Program and Five-Year Plan } \\
\text { Administration }\end{array}$ \\
\hline 14 & 2 & PPPL Underground Storage Tank Remediation \\
\hline 15 & 3 & PPPL Storm-Water Discharge Characterization \\
\hline 16 & 4 & PPPL Radioactive Waste Operations \\
\hline 17 & 5 & PPPL Hazardous Waste Operations \\
\hline 18 & 6 & BNL New Hazardous Waste Management Facility \\
\hline 19 & 7 & BNL Hazardous Radioactive Waste Disposal Operations \\
\hline 20 & 8 & ANL-West Radioactive Sodium Waste Process Facility \\
\hline 21 & 9 & ANL-West Liquid Effluent Monitoring \\
\hline 22 & 10 & $\begin{array}{l}\text { ANL-West Low-Level Waste Disposal to Radioactive Waste } \\
\text { Management Complex }\end{array}$ \\
\hline 23 & 11 & ANL-East Laboratory Wastewater Treatment Plant Upgrade \\
\hline \multirow[t]{2}{*}{24} & 12 & ANL-East Continuity of Operations \\
\hline & & Albuquerque \\
\hline 25 & 1 & LANL TRU Solid Waste Storage Operations \\
\hline 26 & 2 & LANL Radioactive Liquid Waste Treatment \\
\hline 27 & 3 & LANL Low-Level Radioactive Waste Disposal \\
\hline 28 & 4 & KCP Replacement of Industrial Piping \\
\hline 29 & 5 & KCP Modification of Demolition Lot \\
\hline 30 & 6 & KCP Facility Operations and Maintenance \\
\hline 31 & 7 & Mound Plant Radioactive Waste Management \\
\hline 32 & 8 & Mound Plant Mixed Waste Management \\
\hline 33 & 9 & Mound Plant Hazardous Waste Management \\
\hline
\end{tabular}


TABLE 6 Funding Units and Alternatives for Richland

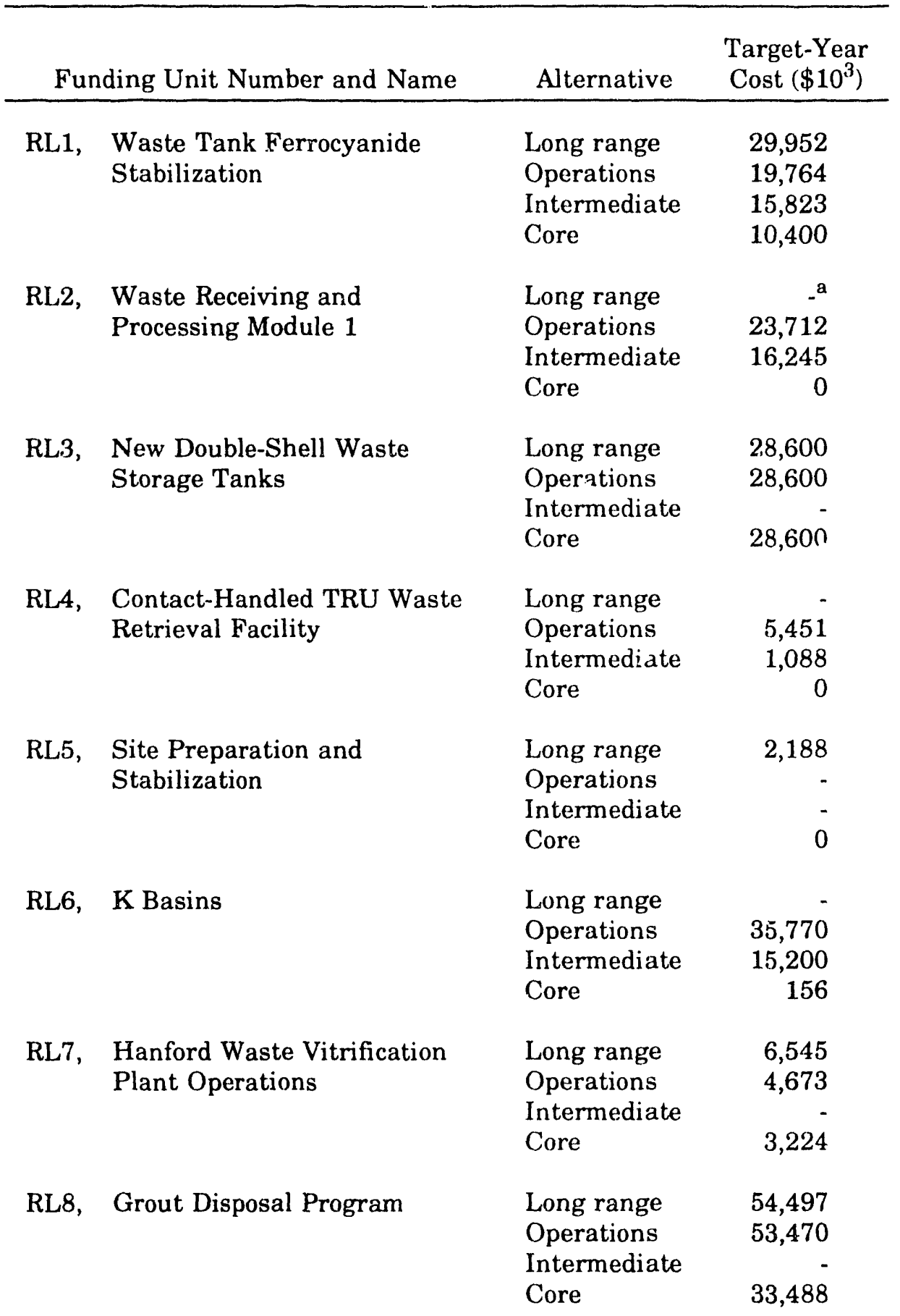


TABLE 6 (Cont.)

\begin{tabular}{llr}
\hline Funding Unit Number and Name & Alternative & $\begin{array}{r}\text { Target-Year } \\
\text { Cost }\left(\$ 10^{3}\right)\end{array}$ \\
\hline \multirow{2}{*}{ RL9, Environmental Sampling and } & Long range & - \\
Analysis & $\begin{array}{l}\text { Operations } \\
\text { Intermediate }\end{array}$ & 10,033 \\
& Core & 6,240 \\
RL10, 200-Area Sanitary Sewer & Long range & 357 \\
& Operations & 357 \\
& Intermediate & - \\
\hline
\end{tabular}

a Indicates that the funding unit manager did not develop this alternative.

TABLE 7 Funding Units and Alternatives for Rocky Flats

\begin{tabular}{|c|c|c|}
\hline Funding Unit Number and Name & Alternative & $\begin{array}{r}\text { Target-Year } \\
\text { Cost }\left(\$ 10^{3}\right) \\
\end{array}$ \\
\hline \multirow{4}{*}{$\begin{array}{l}\text { RF1, Off-site Transport and } \\
\text { Disposal of Waste }\end{array}$} & Long range & $-a^{a}$ \\
\hline & Operations & 4,056 \\
\hline & Intermediate & 1,045 \\
\hline & Core & 459 \\
\hline \multirow{4}{*}{$\begin{array}{l}\text { RF2, Liquid Waste Treatment } \\
\text { Operations and Upgrade, } \\
\text { Bldg. } 374\end{array}$} & Long range & 19,282 \\
\hline & Operations & 16,640 \\
\hline & Intermediate & \\
\hline & Core & 10,400 \\
\hline
\end{tabular}

a Indicates that the funding unit manager did not develop this alternative. 
TABLE 8 Funding Units and Alternatives for Chicago

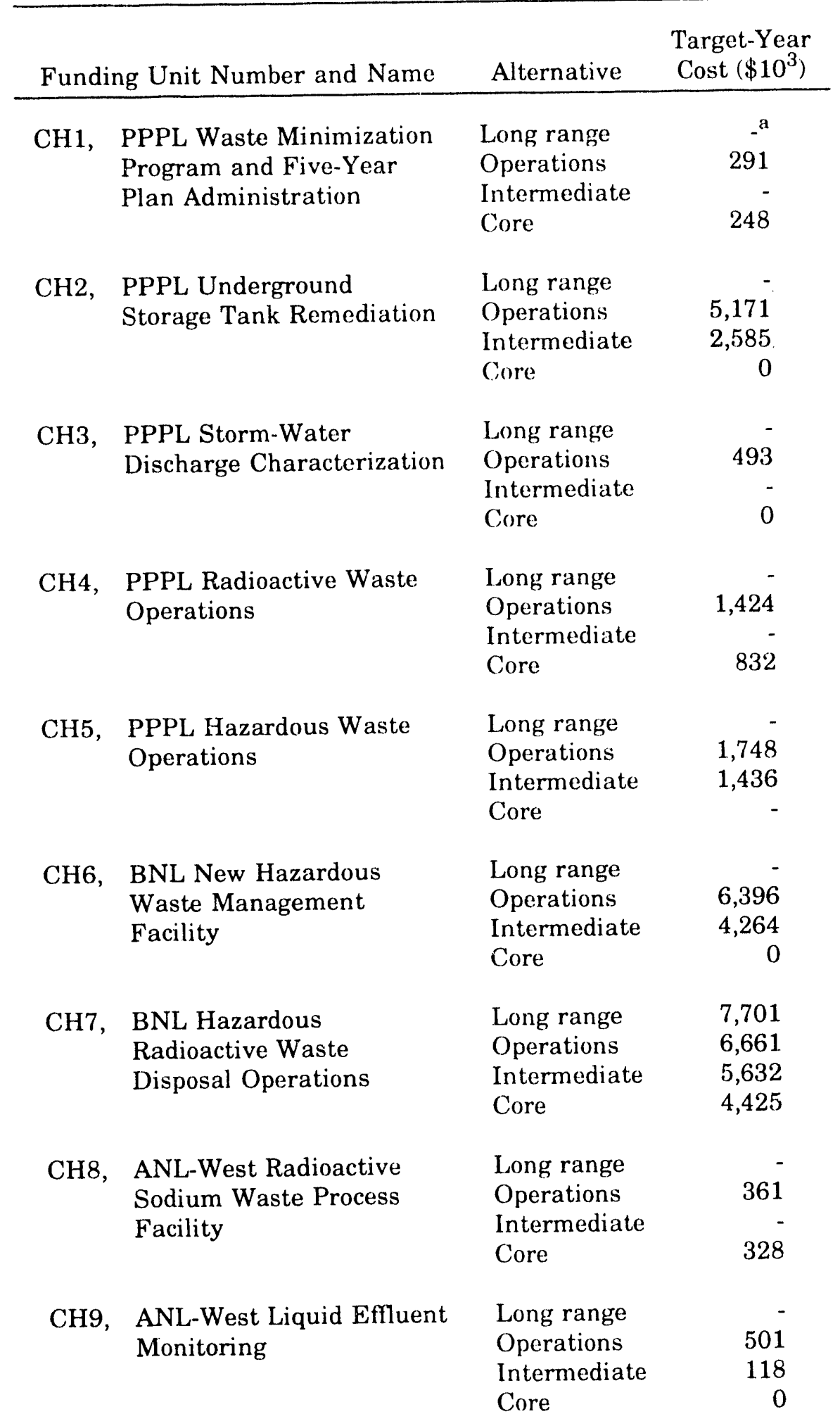


TABLE 8 (Cont.)

\begin{tabular}{llr}
\hline Funding Unit Number and Name & Alternative & $\begin{array}{r}\text { Target-Year } \\
\text { Cost }\left(\$ 10^{3}\right)\end{array}$ \\
\hline $\begin{array}{clr}\text { CH10, ANL-West LLW Disposal } \\
\text { to Radioactive Waste } \\
\text { Management Complex }\end{array}$ & $\begin{array}{l}\text { Long range } \\
\text { Operations }\end{array}$ & - \\
& Intermediate & - \\
Core & 265 \\
CH11, ANL-East Laboratory & Long range & - \\
Wastewater Treatment & Operations & 832 \\
Plant Upgrade & Intermediate & 416 \\
& Core & 0 \\
CH12, ANL-East Continuity of & Long range & 5,046 \\
Operations & Operations & 2,430 \\
& Intermediate & - \\
& Core & 208 \\
\hline
\end{tabular}

a Indicates that the funding unit manager did not develop this alternative. 
TABLE 9 Funding Units and Alternatives for Albuquerque

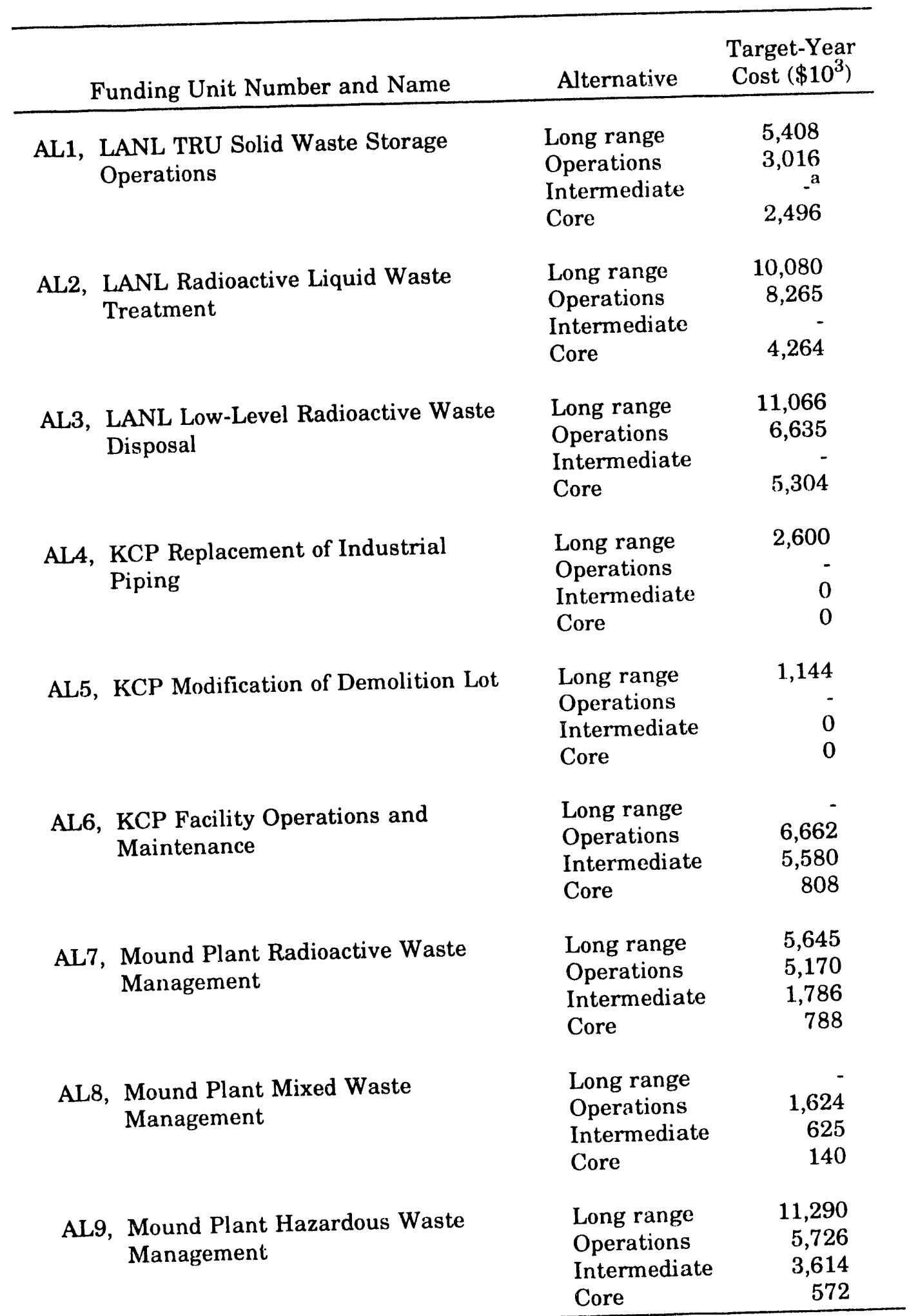

a Indicates that the funding unit manager did not develop this alternative. 


\section{PUBLIC PARTICIPATION IN THE PILO'T S'TUDY}

Public participation in the pilot study continued a process that began early in RASS development. This section places interactions with the public in the context of earlier RASS public participation activities and EM-wide initiatives. It lists EM-wide and RASS-specific public participation objectives, explains the interactions between external parties and WM staff at each facility during the pilot study, summarizes the issues raised by external parties, and draws conclusions from the results of the pilot study. Each of these topics focuses on the pilot study, but the significance of the discussion lies in how public participation in the pilot study informs or reflects the larger process and policy.

\subsection{PUBLIC PARTICIPATION OBJECTIVES}

Early in the development of RASS, in spring and summer 1991, WM decided to make public participation an integral component of the development process. At the same time, an EM-wide working group was formulating a public participation policy and approach to be shared by all EM offices. The planning and implementation of public participation in RASS have been consistent with and parallel to the development of the EM-wide policy. Finalized by EM and distributed on November 5, 1992, by Assistant Secretary Leo Duffy, the policy states that "the public should have the opportunity to participate in the EM decision-making process for program planning, design, and implementation" and that the public is to be provided with "accurate, complete, and timely information and early, meaningful participation opportunities." It further states that "an effective public participation program is essential to the success of the EM program" and notes that "an active public participation program" will:

- Enable the public to participate in public policy decisions about matters that affect them;

- Help DOE make better decisions that incorporate legal, technical, economic, environmental, and social factors, and that address public values and concerns;

- Provide a means for DOE to build consensus among the various interests involved in addressing major issues and problems;

- Assist DOE in building credibility with the public by demonstrating openness, responsiveness, and accountability; and

- Encompass activities necessary to comply with applicable laws, regulations, negotiated agreements, and DOE policy.

Public participation in RASS development overall is designed to meet EM's general objectives for public participation. 
In addition, a specific objective of the RASS pilot study was to determine effective roles for the public in the continuing development and implementation of RASS. The pilot study provided an opportunity to examine alternative public participation approaches in field office working environments and therefore generated useful information about alternative ways for public participation in RASS.

The extent to which the EM-wide objectives are met by public participation in RASS may be clearer once the system is more fully developed and operational, though some preliminary conclusions can be drawn. More important, public participation in the pilot study suggests effective roles for the pullic in the continuing development and eventual implementation of RASS. Section 4.4 discusses these preliminary conclusions and suggested roles.

\subsection{SUMMARY OF PUBLIC PARTICIPATION}

More than 80 persons were interviewed in spring and fall 1991 to discuss the proposed RASS concept. These individuals represented more than 50 organizations located primarily in states that host DOE facilities and in Washington, D.C. Waste Management subsequently invited many of these persons to discuss the RASS draft design concept at a national workshop in Atlanta in late January 1992. The workshop brought together 18 persons from state and federal regulatory agencies, tribal governments, the Congressional

Research Service, the decision science community, the public policy sector, labor, and industry. Representatives of environmental organizations were invited, but none attended. At this workshop, WM proposed that field offices invite regulators and other appropriate parties to attend a review session during forthcoming RASS pilot studies.

Later in the spring, whe FO/HQ Working Group discussed mechanics for public participation during the pil.st studies. It became clear that public participation practices varied among the field offices and installations. As a result, WM decided that field offices should take the lead in coordinating public participation for their pilot study. Headquarters limited its guidance to defining the characteristics of an appropriate "public" and suggesting that the number of invited participants be limited to "working group" size. The following sections give an overview of the public participation activities at each of the four pilot study locations.

\subsubsection{Chicago}

The first RASS pilot study, conducted in Chicago in late June 1992, did not include public participation. Because of the proximity of the Chicago Field Office to ANL, this pilot study evolved into a two-week-long series of working consultations between RASS developers and program and budget officials. 


\subsubsection{Albuquerque}

The public did not participate in the RASS pilot study conducted at the Albuquerque Field Office on July 21-24, 1992. The Albuquerque Field Office and participating installation personnel invited state and U.S. Environmental Protection Agency (EPA) regulators, but none accepted.

\subsubsection{Richland}

External parties participated in a review session on the final day (August 28, 1992) of the Richland Field Office's five-day pilot study. Invited participants were members or representatives of the Hanford Oversight Review Committee, which consists of state regulators from Washington and Oregon; representatives from the EPA; and representatives from the Yakima Indian Nation and Confederated Tribes of the Umatilla Indian Reservation. In the four days before the review session, Richland program and budget personnel worked in teams with RASS developers to understand and supply data elements required by RASS.

\subsubsection{Rocky Flats}

State and EPA regulators and interested members of the public participated in two RASS pilot study activities at the Rocky Flats Office: a prepilot briefing held July 20, 1992, and a pilot study scoring review and summary session conducted September 9-10, 1992.

Waste Management officials at Rocky Flats adopted a consultative approach to conducting their pilot study. They invited the public to a prepilot briefing conducted by RASS developers. At this meeting, the public and DOE and contractor program and budget personnel received an initial orientation to the pilot study objectives and approach. During the follow-up pilot study scoring and review session, Rocky Flats program and budget personnel reviewed funding unit scoring sheet data and modified some entries because they had learned more about RASS inputs.

\subsubsection{Consultation on Compliance and Other Scales}

While preparing and conducting the pilot studies, WM solicited input from interested and affected parties. In May 1992, WM requested and received comments on the proposed compliance scale for the pilot study from a number of persons who had attended the national workshop. In August 1992, WM met with representatives of tribal governments during the Richland pilot study to hear about tribal interests in and concerns about the Hanford site. This input was solicited to further develop RASS objectives and scales after the pilot study. 


\subsection{SUMMARY OF COMMENTS}

Comments from external parties can be grouped into four broad categories: use of RASS, compliance, objectives and scales, and management issues. Table 10 lists these comments by issue type and indicates the source or sources of the comment. Comments listed in the table were made at the national workshop, in correspondence or conversations since the national workshop, or at pilot study prebriefing sessions or summary sessions.

Many of the comments listed in Table 10 were raised or referenced by implication at pilot study sessions where external parties participated. Waste Management would neither necessarily frame the issues in these terms nor agree with the implications contained in the following statements.

State and federal regulators have focused many of their comments on how DOE intends to meet commitments under pollution control statutes and federal facility compliance agreements and on how RASS relates to the budget development process. Tribal government representatives have expressed concerns about the environmental consequences of DOE's continued waste operations and environmental restoration activities. They have also expressed a strong desire to interact with $\mathrm{DOE}$ on a government-to-government basis rather than as one of many elements of DOE's "public."

Many sources commented on DOE's sharing of information and consultation with members of the public and affected parties. Representatives of many interests (e.g., local community activists; environmentalists; labor; public policy professionals; local, state, and federal regulators; tribal government representatives) would like to be apprised of policy and planning alternatives contemplated by DOE decision makers and have an opportunity to offer their input before DOE makes final decisions.

Finally, many external parties believe that improvements to DOE policies and processes would lead to better decision making. Some of these individuals advocate that DOE take a "systems engineering" approach, others a "holistic" approach, to program planning.

\subsection{PRELIMINARY CONCLUSIONS}

Public participation activities in RASS up to and including the pilot study have provided enough information to suggest some tentative conclusions concerning the following areas:

- The degree to which public participation in RASS is meeting EM's public participation policy goals, and

- The contributions of public participation toward defining effective roles for the public in a subsequent full-scale test or implementation of RASS. 
TABLE 10 Prominent Issues Raised by External Parties

\begin{tabular}{|c|c|c|}
\hline Issue Type & Comment/Issue & Source \\
\hline \multirow[t]{2}{*}{ Use of RASS } & RASS should not be used to develop budget cases. & Regulators \\
\hline & $\begin{array}{l}\text { RASS should only be used to analyze "discretionary" } \\
\text { activities. }\end{array}$ & Regulators \\
\hline \multirow[t]{4}{*}{ Compliance } & $\begin{array}{l}\text { Laws, regulations, and agreements are sufficient guidelines } \\
\text { for establishing budget priorities. }\end{array}$ & Regulators \\
\hline & $\begin{array}{l}\text { DOE should not distinguish between legal and regulatory } \\
\text { compliance drivers by rank order or severity of consequence } \\
\text { of noncompliance; rather, DOE should allocate sufficient } \\
\text { funding to meet all compliance drivers. }\end{array}$ & Regulators \\
\hline & $\begin{array}{l}\text { Use of RASS by budget planners may make them liable for } \\
\text { "knowing violations" of compliance requirements. }\end{array}$ & Regulators \\
\hline & $\begin{array}{l}\text { The compliance scale does not adequately reflect DOE's } \\
\text { obligations to consult with tribes on a government-to- } \\
\text { government basis or to accord proper stature to the } \\
\text { enforcement of tribal rights under treaties. }\end{array}$ & Tribes \\
\hline \multirow[t]{3}{*}{$\begin{array}{l}\text { Objectives } \\
\text { and scales }\end{array}$} & $\begin{array}{l}\text { The S\&H scale should measure exposure of workers to toxic } \\
\text { chemicals and hazardous materials. }\end{array}$ & $\begin{array}{l}\text { Regulators, general } \\
\text { public }\end{array}$ \\
\hline & $\begin{array}{l}\text { The objectives for the RASS pilot study do not account for } \\
\text { long-term impacts to safety and health and to future land } \\
\text { use options. }\end{array}$ & Tribes \\
\hline & $\begin{array}{l}\text { The objectives for the RASS pilot study do not measure } \\
\text { benefits from waste minimization practices and technology } \\
\text { development work. }\end{array}$ & Regulators \\
\hline \multirow[t]{4}{*}{$\begin{array}{l}\text { Management } \\
\text { issues }\end{array}$} & $\begin{array}{l}\text { WM should take a systems engineering approach to waste } \\
\text { management; WM should explain the role of RASS in an } \\
\text { integrated management system. }\end{array}$ & Regulators \\
\hline & $\begin{array}{l}\text { RASS should be available for use at the field office or } \\
\text { installation level for local use. }\end{array}$ & $\begin{array}{l}\text { Field office pilot } \\
\text { study participants, } \\
\text { general public }\end{array}$ \\
\hline & $\begin{array}{l}\text { EM should consider whether it needs multiple priority or } \\
\text { allocation systems or whether a single, integrated system } \\
\text { should be developed. }\end{array}$ & $\begin{array}{l}\text { OTA, regulators, } \\
\text { general public }\end{array}$ \\
\hline & $\begin{array}{l}\text { WM should do a better job of involving external parties in } \\
\text { its planning and decision-making processes. }\end{array}$ & $\begin{array}{l}\text { OTA, regulators, } \\
\text { tribes, general public }\end{array}$ \\
\hline
\end{tabular}

a Office of Technology Assessment. 


\subsubsection{EM Public Participation Policy Goals}

The public participation policy adopted by EM in November 1992 identified five goals for public participation. Sections 4.4.1.1-4.4.1.5 evaluate the degree to which RASS appears to be meeting each goal at this stage of development.

\subsubsection{Enable Public Input}

One goal of EM's public participation policy is to "... enable the public to participate in public policy decisions about matters that affect them.” The following RASS activities have provided such opportunities:

- One-on-one and small group interviews with RASS development team members,

- A national workshop with representatives from many different interests and perspectives,

- Predecisional solicitation of comments from interested and affected parties, and

- Involvement in RASS pilot studies.

\subsubsection{Improve DOE Decisions}

A second goal of EM's public participation policy is to “. . . help DOE make better decisions that incorporate legal, technical, economic, environmental, and social factors, and that address public values and concerns." Although significant RASS issues remain to be decided, it is clear that public participation has contributed to the identification and consideration of many factors, values, and concerns. Many of these contributions are discussed at greater length throughout this report. A partial accounting includes the following:

- The importance of compliance requirements in program and budget decision making (a legal factor),

- The need for additional scales for RASS (technical factors),

- The need to promote waste minimization (economic and environmental factors),

- The existence of perceived risk (a social factor), and

- The effort to understand and respond to the concerns and values of tribal governments (a factor that results from implementation of DOF's Native American policy). 
At this interim phase, it is premature to conclude what effect public participation ultimately will have on RASS development. However, some preliminary effects are apparent from public participation activity to date. External parties have focused attention on the importance and the difficulty of dealing with "the compliance issue." Despite any appearances to the contrary, this issue is neither a single issue nor a simple set of issues to resolve. However, if WM and the regulatory community can agree on effective ways to negotiate solutions to specific problems related to compliance issues, it is possible that WM and external parties will welcome RASS for the analytical information that it provides and for its structured thinking process.

\subsubsection{Build Consensus}

A third goal of EM's public participation policy is to “. . provide a means for DOE to build consensus among the various interests involved in addressing major issues and problems." As of the completion of the pilot studies, it is too early to know whether a consensus about RASS will emerge. At this stage of development, individuals hold a variety of opinions about RASS. Discussions to date with interested members of the public and affected parties have helped to identify issues and to promote dialogue on possible resolution of those issues. Waste Management believes that the structured approach of RASS, where costs and benefits are explicitly identified for program activities, should contribute information that would be useful in building consensus.

\subsubsection{Help DOE Build Credibility}

A fourth goal of EM's public participation policy is to “. . . assist DOE in building credibility with the public by demonstrating openness, responsiveness, and accountability." The RASS public participation process has not included any quantifiable means for measuring the effectiveness of activities in meeting this goal. However, comments by some individuals during interviews with RASS developers, at the national workshop, during consultations about the compliance and other scales, and during the pilot studies have suggested some progress in this area.

\subsubsection{Meet Compliance Requirements}

A fifth goal of EM's public participation policy is to “. . . encompass activities necessary to comply with applicable laws, regulations, negotiated agreements, and $\mathrm{DOE}$ policy." That is, one reason for conducting public participation in certain DOE projects is that it is required by certain laws and agreements. RASS development is not a project for which public participation is necessarily mandated, but it is being developed to help WM analyze budget data concerning compliance-driven activities. State and federal regulators and at least one state's office of attorney general have expressed interest in RASS, and the public participation component of RASS development has provided a means for WM and those external parties to discuss issues that concern them. 


\subsubsection{Defining Effective Roles for the Public}

The above objectives are general and pertain to the whole process of public involvement in RASS; a more specific objective for the pilot study was to test effective roles for the public in the continuing development and implementation of RASS.

The Albuquerque, Richland, and Rocky Flats field offices provided information about public roles, but their public participation activities varied widely. This difference is not surprising, given that each DOE installation has a unique relationship with its host communities and federal and state regulators. A tentative conclusion to be drawn is that it is appropriate for each field office to develop its own set of public participation approaches for soliciting input from external parties on a regular basis. Such approaches should be flexible to accommodate differing levels of interest and involvement as circumstances and the focus of public attention change.

In keeping with the EM-wide policy of integrating and consolidating public participation activities when feasible, WM is considering developing guidance to suggest that each field office use existing, ongoing public participation channels and activities to involve external parties in the RASS test and to inform the general public. For example, a citizens' advisory committee could review and comment on the purposes and results of the test; the general public could receive information about the RASS test in advance of a site-specific plan or other regularly scheduled meeting and then ask questions at the meeting; or an article in the regular facility newsletter could be used to inform the general public about the timing and purposes of the RASS test. However, the precise methods would be determined by the field offices.

Waste Management is currently considering three potential roles for external parties in a full-scale test of RASS. Field offices, perhaps in consultation with external parties, could choose whichever of the following roles best suits their circumstances and relationships with external parties:

- Team role: External parties would work with field office staff to assemble and score the funding unit alternatives. The DOE would retain final decision-making responsibility, but external parties would contribute to the preliminary discussions about the RASS process (e.g., formulating funding unit alternatives and scoring them). They would attend all manager-level meetings concerning RASS. They would be trained in RASS at the same time that managers are trained and receive the same guidance.

- Consultative role: Field office staff would do the initial work (i.e., writing a first draft) to assemble and score funding unit alternatives. External parties and field office staff would then work together to adjust or fine-tune the alternatives and scores. External parties would receive separate training and be invited to some of the manager-level meetings concerning RASS (e.g., the pilot study tests in 
which they were invited to the second or third day of the scoring workshops).

- Review and comment role: Field office staff would assemble and score the funding unit alternatives without input from external parties. External parties could receive separate training. They would receive the results of the test in reasonably complete written form and provide either written or verbal comments on the funding unit alternatives and scores. Separate from external parties, field office staff would consider the comments and incorporate them, as appropriate, when revising the alternatives and scores. External parties would learn how the comments were considered through either a meeting or a formal written document.

These proposals for public participation will be discussed with external parties at the next national workshop. One topic to explore might be what other conclusions external parties would draw from the pilot study experience. Another topic might be external parties' views of the proposed flexible alternatives for public involvement and their suggestions for alternative roles for regulators, tribal government representatives, and other interested and affected parties. 


\section{RESULTS AND CONCLUSIONS}

The pilot study was conducted to test a RASS conceptual design that was documented and reviewed in early 1992. Because RASS development is still in its early stages, the pilot study objectives were limited. A small set of the total number of WM funding units (33 out of a total of 350 to 400) was included in the pilot study; thus, the information generated did not test the value of the allocation insights that RASS will eventually produce for the decision maker (pilot study results are not useful for budget analysis). This section of the report discusses how well the pilot study achieved its objectives (Section 5.1), reports RASS results by using an illustrative set of substitution rates (Section 5.2), and presents RASS results from several different perspectives (Section 5.3).

\subsection{ASSESSMENT OF PILOT STUDY OBJECTIVES}

Six objectives guided the design of the pilot study. The comments received from the DOE FO/HQ Working Group, the TRG, and external parties contributed to the selection of the pilot study objectives. These objectives and the outcomes from the pilot study are listed below.

- Objective: Determine whether proposed activities can be meaningfully evaluated on the scales developed to score funding unit alternatives for RASS objectives for WM.

Outcome: Pilot study participants were generally successful in scoring a diverse set of activities on RASS pilot study scales. Some difficulties were encountered in the early pilot studies (Chicago and Albuquerque), which required slight modifications to some scales. These scale changes improved the accuracy of scoring and provided scorers with more meaningful scales. For example, the compliance scale was modified to more accurately reflect the expected DOE regulatory actions. Also, additional guidance was required to improve scoring consistency on the compliance scale because some inconsistency occurred in scoring funding units.

The S\&H scale, which measures the risk to the public through air and water pathways, measures the risk within ranges (e.g., 0 to 1 illness). Although no participants experienced major difficulties in measuring the risks on this scale, some participants stated that additional guidance would produce more consistent results across sites.

The scale that measured waste managed did not include industrial wastewater and did not differentiate among transuranic wastes. Although scoring was not a problem, the scales used in the pilot study do not adequately consider the variability in waste type and should be 
modified to provide a more meaningful evaluation of the value of waste processing.

The range of the scale that measured possible delays in construction of new facilities was considered to be too small. Some participants thought that the scale should include the effects of permit delays (as well as construction time) and that the scale range should be expanded to three years (from a maximium of one year).

Some proposed activities (e.g., research and development; activities other than treatment, storage, or disposal) did not score as well because the entire value of these activities was not included in the scales used in the pilot study. Other scales could be created to measure these contributions to WM objectives (i.e., add to the RASS objectives for WM).

- Objective: Provide an opportunity for the DOE FO/HQ Working Group, the TRG, and external parties to observe the mechanics of the proposed system.

Outcome: Representatives of four DOE field offices participated in the pilot study, and one field office (Oak Ridge) sent an observer to one pilot study. All nonparticipating FO/HQ Working Group members were invited to observe any of the four pilot studies, but attendance was limited, mainly because of scheduling conflicts.

The Richland pilot study included the participation of two individuals with the Congressional Research Service (one is a member of the TRG, and both attended the first national workshop of external parties). They observed the scoring process and the review session held on the last day. Because the scoring at Richland was conducted in small groups, participants were able to observe the scoring judgments directly.

External parties participated in the Richland and Rocky Flats pilot studies. At Richland, external parties participated in an all-day review session the last day of the pilot study. They listened to presentations and commented on the RASS scales, the selection of funding unit alternatives, scoring judgments made by $\mathrm{DOE}$ and contractors, and the results from the RASS model. The external participation at Rocky Flats was more interactive. External parties were involved in the Rocky Flats prepilot meeting and the pilot study. Because the Rocky Flats pilot study had two funding units, the participants observed the mechanics of RASS at a very basic level.

- Objective: Evaluate the availability of quality data and the capability of project managers to niake judgments to support RASS implementation. 
Outcome: Field office staff and contractors were able to make judgments needed to define funding unit alternatives and to score these alternatives on the scales. Approximately 50 field office staff (four offices) and contractors (nine sites) were involved in the scoring of funding unit alternatives. In addition, several external parties were involved in the scoring at Rocky Flats; they did not experience major difficulties. All scoring was conducted with little pretraining. The first part of each scoring session could be characterized as an on-the-job training session. In the next RASS application, more thorough training should be provided to aid the scorers.

Most scoring was conducted with direct input from the appropriate project manager. In some cases, the project manager had difficulty in determining a quantitative score; ANL staff assisted in developing quantitative judgments. In some cases, detailed quantitative analyses were available to support their judgments. However, field office staff, contractors, and external parties who participated in the pilot study stated that additional scoring guidance would improve the consistency of scoring.

- Objective: Determine the level of effort needed by field offices and contractors to work with the system.

Outcome: Effort to score funding units varied considerably. A brief introductory lecture was the only training given before the scoring sessions. Therefore, each new scorer usually required some time to understand what information was being requested (on-the-job training). The time required to score a single funding unit varied between one and three hours (including on-the-job training). The longer times usually corresponded to funding units with multiple activities that required more detailed scoring; the shorter times usually were associated with single-activity funding units. If a scorer was scoring more than one funding unit, the learning curve was steep, and the time required for scoring the second or third funding unit was less than half that needed for scoring the first funding unit.

The general conclusion is that RASS will require additional effort beyond what is typically required for preparation of activity data sheets. However, if the RASS process can be coordinated with preparation of these sheets, the additional effort required for RASS is reasonable.

- Objective: Identify the type and amount of training and guidance needed to implement the system successfully.

Outcome: Although scoring at all pilot studies proceeded well, all field offices commented that more detailed written guidance and training on 
methods of scoring activities on the scales would be required for any larger test of RASS because the RASS development team would not be present to assist in scoring. Group training that includes scoring workshops would be useful. The DOE FO/HQ Working Group suggested developing a training film that could be used as an introductory training program for RASS. All three types of training and guidance will be considered for the next RASS test.

- Objective: Determine an appropriate role for the public should RASS prove to be a useful tool.

Outcome: Because any RASS implementation will be integrated with the overall planning activities at a site, the DOE FO/HQ Working Group recommended that public involvement in the RASS development program should be consistent with the site's overall public involvement program. It is expected that different methods will be used because unique conditions exist at each site.

External parties participated in the pilot study in two different ways. At Richland, the public participated in an all-day review session held on the last day. Time was available to explore the logic behind the funding unit selection and the scoring judgments. At Rocky Flats, external participation took a more consultative approach. Rocky Flats staff took the lead in developing the funding units and the alternatives and made the initial scoring judgments. These judgments were discussed with external parties, and, in some cases, the scoring was modified. Although this approach was useful and meaningful for Rocky Flats, which has only a handful of funding units, it probably would be time-consuming at a site that has more than 20 funding unit alternatives. Therefore, general guidance on external participation in the RASS process should be issued to the offices, but each site should choose the form of external participation on the basis of their own situation.

\subsection{RESULTS FOR REFERENCE SUBSTITUTION RATES}

As discussed in Section 2, a method is needed to convert scoring information about nine objectives into a single number, called an "equivalent-cost" figure in RASS. The equivalent-cost figure measures the degree to which an alternative meets the RASS objectives for WM. "Substitution rates" are used to accomplish this conversion. ${ }^{5}$ Substitution rates are dollar values that a decision maker places on measures such as a statistical fatality. The

5 Technically, this conversion is a value function. Readers familiar with multiattribute utility theory will also recognize that the conversion used here is equivalent to a multiattribute utility function. 
substitution rate for a statistical fatality is a measure of the decision maker's "willingness to pay" to avoid a fatality.

This concept is depicted in Figure 9, which indicates that summary scores for each funding unit alternative are converted to an equivalent-cost figure. Some of these summary scores are based on a large amount of scoring information provided by funding unit managers who participated in the pilot study (e.g., cost estimates for as many as 30 years). RASS logically combines the scoring information to produce the summary scores.

The RASS allocation algorithm uses target-year cost data and the equivalent-cost figure of each funding unit alternative to determine an allocation of a fixed WM budget among the funding units that minimizes total equivalent cost. This procedure is indicated in Figure 10.

\subsubsection{Reference Substitution Rates}

Conversion of summary scores into an equivalent-cost figure depends on a set of substitution rates. An illustrative set $^{6}$ of reference substitution rates is listed in Table 11.

Substitution rates are judgments about the relative importance of the nine measures of the RASS objectives for WM. For example, the provider of these substitution rates, hereafter called the decision maker, judged that it is worth $\$ 14$ million (above and beyond actual costs such as fines and restarting a facility) to avoid a single compliance-related facility shutdown. This judgment captures the "cost" of a number of considerations such as the "loss of good will" associated with a shutdown. Equivalent statistical fatalities were valued differently for occupational and public populations; $\$ 15$ million was assigned to an occupational fatality, and $\$ 30$ million was assigned to a public fatality. Safety and health program expenditures were not judged to be cost-effective, and the decision maker assigned 30 cents per dollar spent on $\mathrm{S} \& H$ programs that are not required to meet applicable laws, regulations, treaties, or DOE orders. ("Not cost-effective" means that the decision maker judged that $\$ 1$ spent would result in less than $\$ 1$ of "benefit.") The decision maker judged that $\$ 1$ of waste managed was worth $\$ 1$. A figure of $\$ 9$ million was assigned to the value of reducing schedule status from level $\mathrm{J}$ ( $>1$-yr delay for a project scheduled for completion in the target year) to level $\mathrm{A}$ (no delay). It was judged that it was worth $\$ 10$ million to meet all Headquarters-tracked Five-Year Plan milestones instead of missing all of them. Finally, by definition, $\$ 1$ of WM system cost is worth $\$ 1$. These judgments about substitution rates are used to obtain the allocation results presented in Section 5.2.3.

6 These rates were provided by a member of DOE Headquarters staff before visiting the first field office that participated in the pilot study. For convenience, these rates are referred to as "reference" substitution rates. 


\begin{tabular}{|c|c|c|c|c|c|}
\hline Alternative & $\begin{array}{c}\text { Compliance- } \\
\text { Related } \\
\text { Shutdowns }\end{array}$ & $\begin{array}{l}\text { Equivalent } \\
\text { Worker } \\
\text { Fatalities }\end{array}$ & $\bullet \bullet$ & $\begin{array}{c}\text { WM } \\
\text { System } \\
\text { Cost }\end{array}$ & $\begin{array}{l}\text { Equivalent } \\
\text { Cost }\end{array}$ \\
\hline Core & 3.9 & 0.2 & $\cdots \bullet$ & $\begin{array}{l}\$ 65.6 \\
\text { Million }\end{array}$ & $\begin{array}{l}\$ 170 \\
\text { Million }\end{array}$ \\
\hline Intermediate & 2.6 & 0.3 & $\cdots$ & $\begin{array}{l}\$ 65.8 \\
\text { Million }\end{array}$ & $\begin{array}{l}\$ 115 \\
\text { Million }\end{array}$ \\
\hline Operations & 1.8 & 0.4 & $\cdots$ & $\begin{array}{l}\$ 71.6 \\
\text { Million }\end{array}$ & $\begin{array}{l}\$ 100 \\
\text { Million }\end{array}$ \\
\hline Long Range & 1.3 & 0.5 & $\cdots \bullet$ & $\begin{array}{l}\$ 76.3 \\
\text { Million }\end{array}$ & $\begin{array}{c}\$ 82 \\
\text { Million }\end{array}$ \\
\hline
\end{tabular}

FIGURE 9 Nine Summary Scores for Each Funding Unit Alternative Are Converted into an Equivalent-Cost Figure

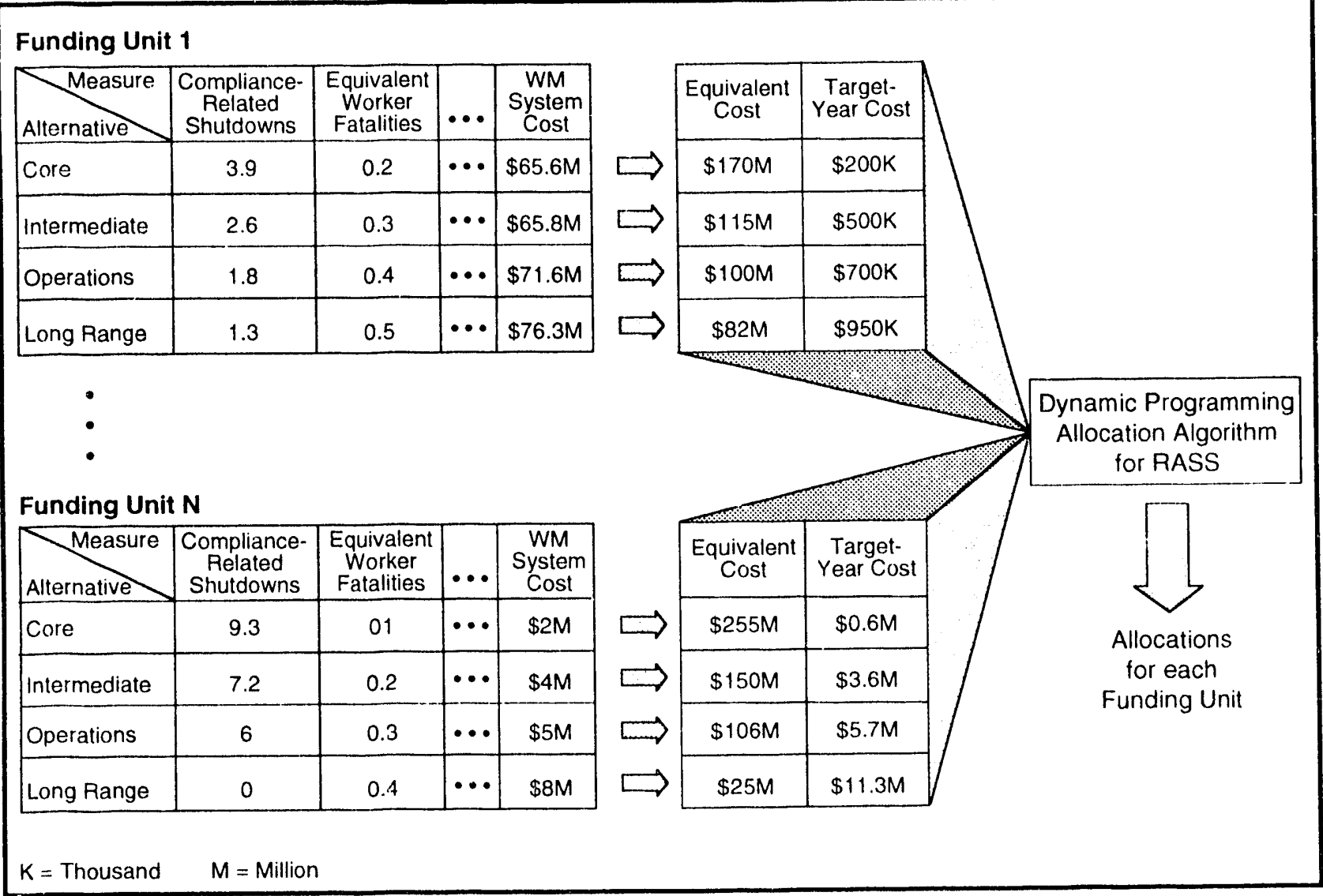

FIGURE 10 A Dynamic Programming Algorithm Uses Target-Year Cost and Equivalent Costs to Allocate Funds among Funding Units 


\subsubsection{Calculating the Equivalent Cost of a Funding Unit Alternative}

The process used to convert nine scores that characterize a funding unit alternative is illustrated in Table 12. A score is multiplied by its corresponding substitution rate, and the product is either added to or subtracted from the equivalent-cost figure. Products for measures that logically increase equivalent cost are added, and products for measures that logically decrease cost are subtracted. Thus, small equivalent costs are more desirable than large equivalent costs, and negative equivalent costs are possible. Negative costs may result, for example, when waste operations are conducted in an extremely efficient and cost-effective manner. Of the :ine measures (Section 2.2), only measures 5 (S\&H expenditures), 6 (dollar value of waste managed), and 8 (percent of Five-Year Plan milestones to be met) decrease equivalent cost; the others increase equivalent cost.

The illustrative calculations, which involve the operations alternative for the Waste

Tank Ferrocyanide Stabilization funding unit at Richland, yield an equivalent cost of $\$ 100.1$ million. Of these summary scores, the ones that increased equivalent cost were 1.81 equivalent shutdowns, 2.02 equivalent public fatalities through air and water exposure pathways, and $\$ 71.58$ million in WM system costs. Summary scores that decreased equivalent cost were $\$ 47.66$ million of waste managed and meeting $100 \%$ of Headquarterstracked Five-Year Plan milestones. Transport of waste accounted for 0.014 equivalent occupational fatalities and no public fatalities. Because no schedule delays occurred, the increase in equivalent cost associated with delays was zero.

\subsubsection{Resource Allocation with the Reference Substitution Rates}

The reference st.bstitution rates were used to calculate an equivalent-cost figure for each funding unit alternative. These cost figures are listed in Tables 13-16 (for Richland, Rocky Flats, Chicago, and Albuquerque, respectively) along with target-year cost data. For example, for the intermediate alternative for funding unit RL1 (Hanford Waste Tanl: Ferrocyanide Stabilization), Table 13 lists the target-year cost ( $\$ 15.8$ million) and the equivalent cost ( $\$ 115.3$ million). The highest rated funding unit alternative is the long-range alternative for funding unit 31 (AL7, Mound Plant Radioactive Waste Management, listed in Table 16). It has the lowest equivalent cost ( $-\$ 2.4$ billion).

Only one of the Richland funding units (RL1) had four alternatives. Some alternatives for other Richland funding units were not considered in the allocation process because another alternative (for a specific funding unit) had the sam ir less cost and the same or less equivalent cost. For example, three alternatives for RL3 had the same target-year cost ( $\$ 28.6$ million), and the alternatives had different equivalent costs. Thus, only one of the alternatives (long range) was used in the allocation. Some alternatives for the Chicago and Albuquerque field offices were also omitted fro: the optimization for the same reasons. 
TABLE 11 Reference Substitution Rates

\begin{tabular}{|c|c|c|}
\hline No. & Measure & $\begin{array}{l}\text { Substitution } \\
\text { Rate }\left(\$ 10^{6}\right)\end{array}$ \\
\hline 1 & $\begin{array}{l}\text { Equivalent cumulative compliance-related facility shutdowns } \\
\text { (rate per equivalent shutdown) }\end{array}$ & $14^{\mathrm{a}}$ \\
\hline 2 & $\begin{array}{l}\text { Equivalent cumulative statistical occupational fatalities (rate } \\
\text { per equivalent fatality) }\end{array}$ & $15^{\mathrm{b}}$ \\
\hline 3 & S\&H programs expenditures (rate per $\$ 10^{6}$ ) & $0.30^{c}$ \\
\hline 4 & $\begin{array}{l}\text { Equivalent cumulative statistical public fatalities from air and } \\
\text { water pathway exposures (rate per equivalent fatality) }\end{array}$ & $30^{b}$ \\
\hline 5 & $\begin{array}{l}\text { Equivalent cumulative statistical public fatalities from } \\
\text { transportation accidents (rate per equivalent fatality) }\end{array}$ & $30^{\mathrm{b}}$ \\
\hline 6 & Capacity/throughput to be met (rate per $\$ 10^{6}$ ) & $1^{\mathrm{d}}$ \\
\hline 7 & $\begin{array}{l}\text { New capacity status (rate for changing level } \mathrm{H} \text { to level A; see } \\
\text { Table 4) }\end{array}$ & $9^{\mathbf{e}}$ \\
\hline 8 & $\begin{array}{l}\text { Average percent of Five-Year Plan milestones to be met (rate } \\
\text { per percent of milestones to be met) }\end{array}$ & $0.1^{\mathrm{f}}$ \\
\hline 9 & WM system cost (rate per $\$ 10^{6}$ ) & $1^{\mathrm{g}}$ \\
\hline
\end{tabular}

a The provider of these substitution rates (hereafter called the decision maker) judged that it is worth $\$ 14$ million (above and beyond actual costs such as fines and restarting a facility) to avoid a single compliance-related facility shutdown. The rate is per equivalent shutdown. One equivalent shutdown corresponds to either a projected shutdown or a number of less severe compliance issues that, in a collective sense, are equivalent to a shutdown.

b The decision maker valued equivalent statistical fatalities differently for occupational and public populations; $\$ 15$ million was assigned to an occupational fatality, and $\$ 30$ million was assigned to a public fatality. Morbidity (person-days lost) contributes to this measure: 6,000 person-days lost is equivalent to one statistical fatality.

c Safety and health program expenditures were not judged to be cost-effective, and the decision maker assigned a value of 30 cents per dollar spent on $\mathrm{S} \& \mathrm{H}$ programs that are not required to meet applicable laws, regulations, treaties, or DOE orders.

$\mathrm{d}$ The decision maker judged $\$ 1$ of waste managed was worth $\$ 1$.

- A figure of $\$ 9$ million was assigned to the value of reducing schedule status from level $\mathrm{J}$ (>1-yr delay for a project scheduled for completion in the target year) to level A (no delay).

$f$ The decision maker judged that it was worth $\$ 10$ million to meet all Headquarters-tracked Five-Year Plan milestones insteat of missing all of thern.

f By definition, $\$ 1$ of WM system cost is worth $\$ 1$. 
TABLE 12 Illustrative Calculations for Obtaining the Equivalent Cost of a Funding Unit Alternative (reference substitution rates) ${ }^{a}$

\begin{tabular}{|c|c|c|c|c|}
\hline No. & Measure & $\begin{array}{c}\text { Summary } \\
\text { Score }^{b}\end{array}$ & $\begin{array}{l}\text { Substitution } \\
\text { Rate }^{c}\left(\$ 10^{6}\right) \\
\end{array}$ & $\begin{array}{l}\text { Equivalent } \\
\operatorname{Cost}^{\mathrm{d}}\left(\$ 10^{6}\right) \\
\end{array}$ \\
\hline 1 & $\begin{array}{l}\text { Compliance-related facility } \\
\text { shutdowns (equivalents) }\end{array}$ & 1.81 & 14 & 25.31 \\
\hline 2 & $\begin{array}{l}\text { Occupational fatalities } \\
\text { (equivalents) }\end{array}$ & 0.014 & 15 & 0.21 \\
\hline 3 & $\begin{array}{l}\text { Public fatalities (transportation, } \\
\text { equivalents) }\end{array}$ & 0 & 30 & 0.00 \\
\hline 4 & $\begin{array}{l}\text { Public fatalities (air and water, } \\
\text { equivalents) }\end{array}$ & 2.02 & 30 & 60.66 \\
\hline 5 & S\&H expenditures (present value) & 0 & -0.30 & -0.00 \\
\hline 6 & $\begin{array}{l}\text { Dollar value of waste managed } \\
\text { (present value in } \$ 10^{6} \text { ) }\end{array}$ & 47.66 & -1 & -47.66 \\
\hline 7 & Wew capacity status & 0 & 9 & 0.00 \\
\hline 8 & $\begin{array}{l}\text { Percent of Five-year Plan } \\
\text { milestones to be met }\end{array}$ & 100 & -0.1 & -10.00 \\
\hline \multirow[t]{2}{*}{9} & $\begin{array}{l}\text { WM system cost (present value } \\
\text { in } \$ 10^{6} \text { ) }\end{array}$ & 71.58 & 1 & 71.58 \\
\hline & & & Total $^{\mathrm{e}}$ & 100.10 \\
\hline
\end{tabular}

a Richland Field Office, Waste Tank Ferrocyanide Stabilization, operations alternative.

b Developed from scoring information provided by funding unit managers.

c Provided by Headquarters; negative values decrease equivalent cost, and positive values increase equivalent cost.

d Each equivalent-cost component is the product of a score and a substitution rate (i.e., score $\times$ substitution rate).

e Totals may not add because figures have been rounded. 
TABLE 13 Characteristics of Richland Funding Unit Alternatives

\begin{tabular}{|c|c|c|c|c|c|}
\hline $\begin{array}{l}\text { Natl. } \\
\text { No. }\end{array}$ & Fun & ding Unit Number and Name ${ }^{a}$ & Alternative & $\begin{array}{c}\text { Target-Year } \\
\text { Cost }\left(\$ 10^{3}\right)\end{array}$ & $\begin{array}{l}\text { Equivalent } \\
\text { Cost }\left(\$ 10^{6}\right) \\
\end{array}$ \\
\hline 1 & RL1, & $\begin{array}{l}\text { Waste Tank Ferrocyanide } \\
\text { Stabilization }\end{array}$ & $\begin{array}{l}\text { Long range } \\
\text { Operations } \\
\text { Intermediate } \\
\text { Core }\end{array}$ & $\begin{array}{l}29,952 \\
19,764 \\
15,823 \\
10,400\end{array}$ & $\begin{array}{r}82.5 \\
100.1 \\
115.3 \\
170.0\end{array}$ \\
\hline 2 & RL2, & $\begin{array}{l}\text { Waste Receiving and Processing } \\
\text { Module } 1\end{array}$ & $\begin{array}{l}\text { Operations } \\
\text { Intermediate } \\
\text { Core }\end{array}$ & $\begin{array}{r}23,712 \\
16,245 \\
0\end{array}$ & $\begin{array}{l}-48.6 \\
180.4 \\
422.1\end{array}$ \\
\hline 3 & RL3, & $\begin{array}{l}\text { New Double-Shell Waste } \\
\text { Storage Tanks }\end{array}$ & $\begin{array}{l}\text { Long range } \\
\text { Operations } \\
\text { Core }^{b}\end{array}$ & $\begin{array}{r}28,600 \\
28,600^{b} \\
28,600^{b}\end{array}$ & $\begin{array}{c}-335.4 \\
-66.5^{b} \\
510.3^{b}\end{array}$ \\
\hline 4 & RL4, & $\begin{array}{l}\text { Contact-Handled TRU Waste } \\
\text { Retrieval Facility }\end{array}$ & $\begin{array}{l}\text { Operations } \\
\text { Intermediate } \\
\text { Core }\end{array}$ & $\begin{array}{r}5,451 \\
1,088 \\
0\end{array}$ & $\begin{array}{r}42.8 \\
80.0 \\
137.9\end{array}$ \\
\hline 5 & RL5, & $\begin{array}{l}\text { Site Preparation and } \\
\text { Stabilization }\end{array}$ & $\begin{array}{l}\text { Long range } \\
\text { Core }\end{array}$ & $\begin{array}{r}2,188 \\
0\end{array}$ & $\begin{array}{l}2.1 \\
6.6\end{array}$ \\
\hline 6 & RL6, & K Basins & $\begin{array}{l}\text { Operations } \\
\text { Intermediate } \\
\text { Core }\end{array}$ & $\begin{array}{r}35,770 \\
15,200 \\
156\end{array}$ & $\begin{array}{l}176.8 \\
470.0 \\
484.4\end{array}$ \\
\hline 7 & RL7, & $\begin{array}{l}\text { Hanford Waste Vilrification } \\
\text { Plant Operations }\end{array}$ & $\begin{array}{l}\text { Long range } \\
\text { Operations }{ }^{b} \\
\text { Core }\end{array}$ & $\begin{array}{r}6,545 \\
4,673^{b} \\
3,224\end{array}$ & $\begin{array}{l}-954.9 \\
-946.1^{b} \\
-946.3\end{array}$ \\
\hline 8 & RL8, & Grout Disposal Program & $\begin{array}{l}\text { Long range } \\
\text { Operations } \\
\text { Core }\end{array}$ & $\begin{array}{l}54,497 \\
53,470 \\
33,488\end{array}$ & $\begin{array}{r}-542.8 \\
-580.7 \\
473.0\end{array}$ \\
\hline 9 & RL9, & $\begin{array}{l}\text { Environmental Sampling and } \\
\text { Analysis }\end{array}$ & $\begin{array}{l}\text { Operations } \\
\text { Intermediate } \\
\text { Core }^{b}\end{array}$ & $\begin{array}{r}10,033 \\
6,240 \\
6,240^{b}\end{array}$ & $\begin{array}{c}32.6 \\
78.0^{b} \\
230.4^{b}\end{array}$ \\
\hline 10 & RL10, & 200-Area Sanitary Sewer & $\begin{array}{l}\text { Long range } \\
\text { Operations } \\
\text { Core }\end{array}$ & $\begin{array}{r}357 \\
357^{\mathrm{b}} \\
0\end{array}$ & $\begin{array}{c}64.1 \\
73.4^{\mathrm{b}} \\
233.8\end{array}$ \\
\hline
\end{tabular}

a The four field offices have a total of 33 funding units.

b Not used in the allocation because another alternative is available with the same or less cost with the same or less equivalent cost. 
TABLE 14 Characteristics of Rocky Flats Funding Unit Alternatives

\begin{tabular}{cclcc}
\hline $\begin{array}{c}\text { Natl. } \\
\text { No. }\end{array}$ & $\begin{array}{c}\text { Funding Unit Number } \\
\text { and Name }\end{array}$ & Alternative & $\begin{array}{c}\text { Target-Year } \\
\text { Cost }\left(\$ 10^{3}\right)\end{array}$ & $\begin{array}{c}\text { Equivalent } \\
\text { Cost }\left(\$ 10^{6}\right)\end{array}$ \\
\hline \multirow{2}{*}{11} & RF1, Off-site Transport and & Operations & 4,056 & -137.4 \\
& & $\begin{array}{l}\text { Disposal of Waste } \\
\text { Intermediate }\end{array}$ & 1,045 & -130.9 \\
& & Core & 459 & -103.1 \\
& RF2, Liquid Waste Treatment & Long range & 19,282 & -109.5 \\
& Operations and Upgrade, & Operations & 16,640 & -76.1 \\
& Bldg. 374 & Core & 10,400 & 255.8 \\
\hline
\end{tabular}

a The four field offices have a total of 33 funding units.

Allocation results involving all 33 funding units are listed in Table 17. Each row in the table corresponds to a specific total WM budget amount and lists the optimal allocation of that budget across funding units. The largest total budget is listed at the top. Every other row specifies an allocation that has a smaller sum of target-year funding requests for the 33 funding units than is given in the row above it. For example, at a total budget of $\$ 242$ million (which is two-thirds between the minimum [\$115.1 million] and maximum [\$305.4 million] budgets), ${ }^{7}$ RASS recommends the following solution across the 33 funding units:

\section{COLI COCO ILIO OCOC ICCO ICOL LLOI IOLO L,}

where $\mathrm{C}$ denotes core, I denotes intermediate, $\mathrm{O}$ denotes operations, and $\mathrm{L}$ denotes long-range funding alternative. This notation means that funding unit 1 receives its core funding, funding unit 2 receives its operations funding, and so on.

The pilot study had more than $10^{15}$ ways to allocate funds among the 33 funding units. On the basis of the reference substitution rates, nearly 1,100 of these ways are optimal solutions. A solution is optimal if it is not possible to obtain a lower total equivalent cost with a lower total WM budget. Table 17, which lists a subset (29) of the optimal solutions, has the following important properties and features:

- The percentage listed in the first column of each row is the percent between the minimum $(0 \%)$ and maximum (100\%) budget requests.

- Shading denotes differences between a row and the row immediately below.

7 The maximum total funding ( $\$ 305.4$ million) is the sum of the target-year funding requests for the alternatives with the highest target-year requests. Similarly, the minimum total funding level (\$115.1 million) is the sum of the target-year funding requests for the alternatives with the lowest target-year requests, generally the core alternatives. 
TABLE 15 Characteristics of Chicago Funding Unit Alternatives

\begin{tabular}{|c|c|c|c|c|c|}
\hline $\begin{array}{l}\text { Natl. } \\
\text { No. }\end{array}$ & & Funding Unit Number and Name ${ }^{a}$ & Alternative & $\begin{array}{l}\text { Target-Year } \\
\text { Cost }\left(\$ 10^{3}\right)\end{array}$ & $\begin{array}{l}\text { Equivalent } \\
\text { Cost }\left(\$ 10^{6}\right)\end{array}$ \\
\hline 13 & $\mathrm{CH} 1$, & $\begin{array}{l}\text { PPPL Waste Minimization Program and } \\
\text { Five-Year Plan Administration }\end{array}$ & $\begin{array}{l}\text { Operations } \\
\text { Core }\end{array}$ & $\begin{array}{l}291 \\
248\end{array}$ & $\begin{array}{l}-9.7 \\
-3.8\end{array}$ \\
\hline 14 & $\mathrm{CH} 2$, & $\begin{array}{l}\text { PPPL Underground Storage Tank } \\
\text { Remediation }\end{array}$ & $\begin{array}{l}\text { Operations } \\
\text { Intermediate } \\
\text { Core }\end{array}$ & $\begin{array}{r}5,171 \\
2,585 \\
0\end{array}$ & $\begin{array}{r}-11.2 \\
2.2 \\
5.0\end{array}$ \\
\hline 15 & $\mathrm{CH} 3$, & $\begin{array}{l}\text { PPPL Storm-Water Discharge } \\
\text { Characterization }\end{array}$ & $\begin{array}{l}\text { Operations } \\
\text { Core }\end{array}$ & $\begin{array}{r}493 \\
0\end{array}$ & $\begin{array}{r}2.4 \\
15.9\end{array}$ \\
\hline 16 & $\mathrm{CH} 4$, & PPPL Radioactive Waste Operations & $\begin{array}{l}\text { Operations } \\
\text { Core }\end{array}$ & $\begin{array}{r}1,424 \\
832\end{array}$ & $\begin{array}{r}7.5 \\
12.5\end{array}$ \\
\hline 17 & $\mathrm{CH} 5$, & PPPL Hazardous Waste Operations & $\begin{array}{l}\text { Operations } \\
\text { Intermediate }\end{array}$ & $\begin{array}{l}1,748 \\
1,436\end{array}$ & $\begin{array}{l}12.7 \\
19.7\end{array}$ \\
\hline 18 & $\mathrm{CH} 6$, & $\begin{array}{l}\text { BNL New Hazardous Waste Management } \\
\text { Facility }\end{array}$ & $\begin{array}{l}\text { Operations } \\
\text { Intermediate } \\
\text { Core }\end{array}$ & $\begin{array}{r}6,396 \\
4,264 \\
0\end{array}$ & $\begin{array}{r}1.7 \\
11.0 \\
24.6\end{array}$ \\
\hline 19 & $\mathrm{CH} 7$, & $\begin{array}{l}\text { BNL Hazardous Radioactive Waste } \\
\text { Disposal Operations }\end{array}$ & $\begin{array}{l}\text { Long range } \\
\text { Operations }{ }^{b} \\
\text { Intermediate } \\
\text { Core }\end{array}$ & $\begin{array}{r}7,701 \\
6,661^{\mathrm{b}} \\
5,632 \\
4,425\end{array}$ & $\begin{array}{l}-2.5 \\
-0.9^{b} \\
-1.7 \\
12.4\end{array}$ \\
\hline 20 & $\mathrm{CH} 8$, & $\begin{array}{l}\text { ANL-West Radioactive Sodium Waste } \\
\text { Process Facility }\end{array}$ & $\begin{array}{l}\text { Operations } \\
\text { Core }\end{array}$ & $\begin{array}{l}361 \\
328\end{array}$ & $\begin{array}{l}19.7 \\
69.2\end{array}$ \\
\hline 21 & CH9, & ANL-West Liquid Effluent Monitoring & $\begin{array}{l}\text { Operations } \\
\text { Intermediate } \\
\text { Core }\end{array}$ & $\begin{array}{r}501 \\
118 \\
0\end{array}$ & $\begin{array}{r}0.9 \\
5.9 \\
11.6\end{array}$ \\
\hline 22 & $\mathrm{CH} 10$, & $\begin{array}{l}\text { ANL-West LLW Disposal to Radioactive } \\
\text { Waste Management Complex }\end{array}$ & $\begin{array}{l}\text { Operations } \\
\text { Core }\end{array}$ & $\begin{array}{l}529 \\
265\end{array}$ & $\begin{array}{r}-0.3 \\
4.6\end{array}$ \\
\hline 23 & CH11, & $\begin{array}{l}\text { ANL-East Laboratory Wastewater } \\
\text { Treatment Plant Upgrade }\end{array}$ & $\begin{array}{l}\text { Operations } \\
\text { Intermediate } \\
\text { Core }\end{array}$ & $\begin{array}{r}832 \\
416 \\
0\end{array}$ & $\begin{array}{r}-9.2 \\
7.4 \\
31.9\end{array}$ \\
\hline 24 & $\mathrm{CH} 12$, & ANL-East Continuity of Operations & $\begin{array}{l}\text { Long range } \\
\text { Operations } \\
\text { Core }\end{array}$ & $\begin{array}{r}5,046 \\
2,430 \\
208\end{array}$ & $\begin{array}{r}31.1 \\
110.5 \\
151.8\end{array}$ \\
\hline
\end{tabular}

a The four field offices have a total of 33 funding units.

b Not used in the allocation because another alternative is available with the same or less cost with the same or less equivalent cost. 
TABLE 16 Characteristics of Albuquerque Funding Unit Alternatives

\begin{tabular}{|c|c|c|c|c|}
\hline $\begin{array}{l}\text { Natl. } \\
\text { No. }\end{array}$ & Funding Unit Number and Name ${ }^{a}$ & Alternative & $\begin{array}{l}\text { Target-Year } \\
\text { Cost }\left(\$ 10^{3}\right) \\
\end{array}$ & $\begin{array}{l}\text { Equivalent } \\
\text { Cost }\left(\$ 10^{6}\right)\end{array}$ \\
\hline 25 & $\begin{array}{l}\text { AL1, LANL TRU Solid Waste Storage } \\
\text { Operations }\end{array}$ & $\begin{array}{l}\text { Long range } \\
\text { Operations } \\
\text { Core }\end{array}$ & $\begin{array}{l}5,408 \\
3,016 \\
2,496\end{array}$ & $\begin{array}{l}-0.9 \\
37.4 \\
81.2\end{array}$ \\
\hline 26 & $\begin{array}{l}\text { AL2, LANL Radioactive Liquid Waste } \\
\text { Treatment }\end{array}$ & $\begin{array}{l}\text { Long range } \\
\text { Operations } \\
\text { Core }\end{array}$ & $\begin{array}{r}10,080 \\
8,265 \\
4,264\end{array}$ & $\begin{array}{r}-551.0 \\
-479.9 \\
197.3\end{array}$ \\
\hline 27 & $\begin{array}{l}\text { AL3, LANL Low-Level Radioactive } \\
\text { Waste Disposal }\end{array}$ & $\begin{array}{l}\text { Long range } \\
\text { Operations } \\
\text { Core }\end{array}$ & $\begin{array}{r}11,066 \\
6,635 \\
5,304\end{array}$ & $\begin{array}{r}-219.5 \\
-212.5 \\
137.1\end{array}$ \\
\hline 28 & $\begin{array}{l}\text { AL4, KCP Replacement of Industrial } \\
\text { Piping }\end{array}$ & $\begin{array}{l}\text { Long range } \\
\text { Intermediate } \\
\text { Core }^{b}\end{array}$ & $\begin{array}{r}2,600 \\
0 \\
0^{\mathrm{b}}\end{array}$ & $\begin{array}{c}-7.3 \\
5.3 \\
23.5^{\mathrm{b}}\end{array}$ \\
\hline 29 & $\begin{array}{l}\text { AL5, KCP Modification of Demolition } \\
\text { Lot }\end{array}$ & $\begin{array}{l}\text { Long range } \\
\text { Intermediate } \\
\text { Core }^{b}\end{array}$ & $\begin{array}{r}1,144 \\
0 \\
0^{\mathrm{b}}\end{array}$ & $\begin{array}{c}8.6 \\
25.0 \\
51.5^{\mathrm{b}}\end{array}$ \\
\hline 30 & $\begin{array}{l}\text { AL6, KCP Facility Operations and } \\
\text { Maintenance }\end{array}$ & $\begin{array}{l}\text { Operations } \\
\text { Intermediate } \\
\text { Core }\end{array}$ & $\begin{array}{r}6,662 \\
5,580 \\
808\end{array}$ & $\begin{array}{r}3.0 \\
418.7 \\
1,248.6\end{array}$ \\
\hline 31 & $\begin{array}{l}\text { AL7, Mound Plant Radioactive Waste } \\
\text { Management }\end{array}$ & $\begin{array}{l}\text { Long range } \\
\text { Operations } \\
\text { Intermediate } \\
\text { Core }\end{array}$ & $\begin{array}{r}5,645 \\
5,170 \\
1,786 \\
788\end{array}$ & $\begin{array}{r}-2,396.5 \\
-2,010.2 \\
-383.5 \\
264.4\end{array}$ \\
\hline 32 & $\begin{array}{l}\text { AL8, Mound Plant Mixed Waste } \\
\text { Management }\end{array}$ & $\begin{array}{l}\text { Operations } \\
\text { Intermediate } \\
\text { Core }\end{array}$ & $\begin{array}{r}1,624 \\
625 \\
140\end{array}$ & $\begin{array}{r}29.4 \\
131.8 \\
203.4\end{array}$ \\
\hline 33 & $\begin{array}{l}\text { AL9, Mound Plant Hazardous Waste } \\
\text { Management }\end{array}$ & $\begin{array}{l}\text { Long range } \\
\text { Operations } \\
\text { Intermediate } \\
\text { Core }\end{array}$ & $\begin{array}{r}11,290 \\
5,726 \\
3,614 \\
572\end{array}$ & $\begin{array}{r}24.8 \\
106.4 \\
150.6 \\
254.5\end{array}$ \\
\hline
\end{tabular}

a The four field offices have a total of 33 funding units.

b Not used in the allocation because another alternative is available with the same or less cost with the same or less equivalent cost. 


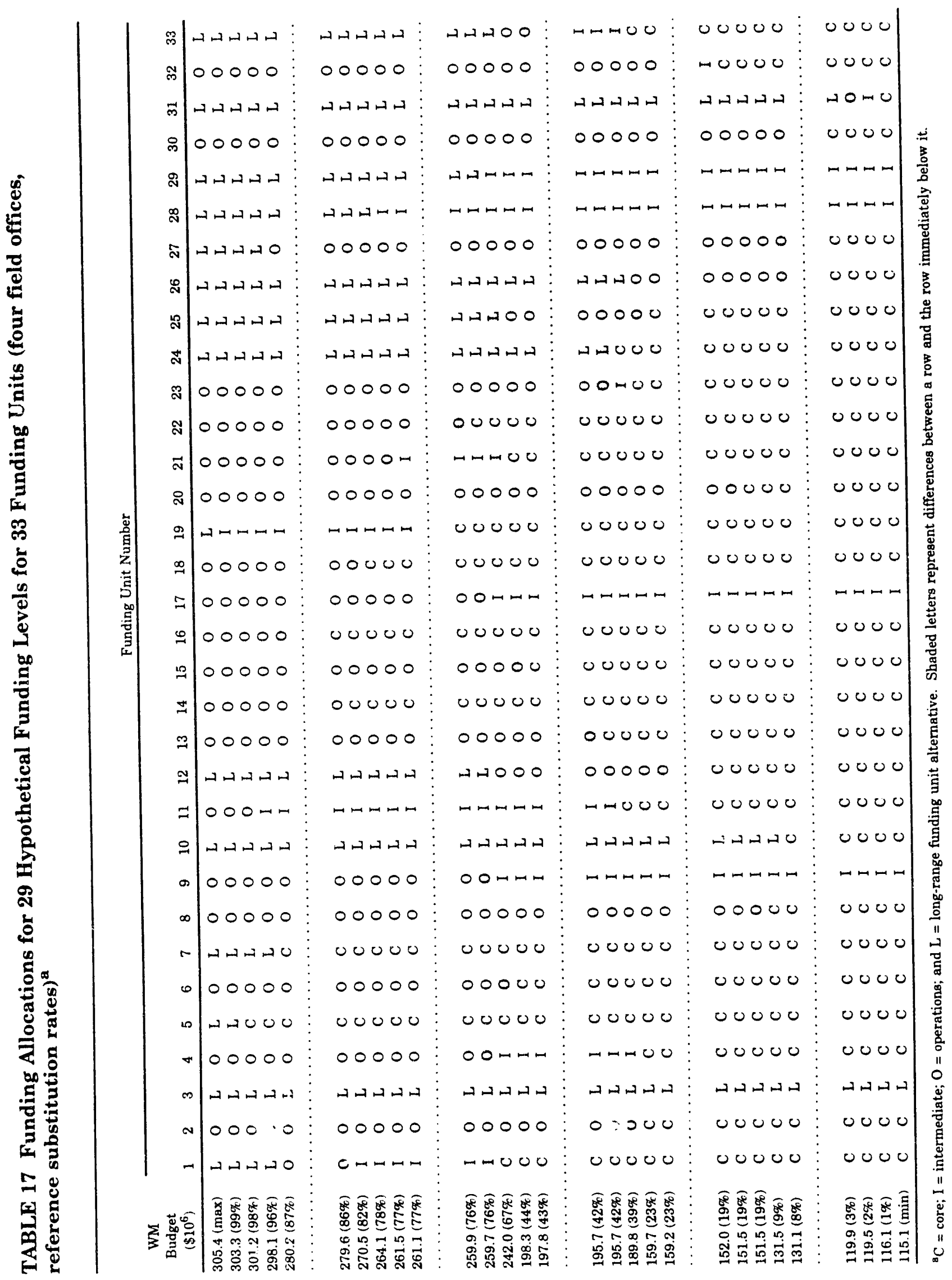


- For each decrease in funding, one or more funding units receive less money, and the others receive the same amount as in the previous (higher funding amount) solution.

- The top row identifies the first funding unit (number 19, which is $\mathrm{CH} 7$ ) that receives a budget decrease when total funding for all field office decreases. (In a sense, this funding unit alternative is most vulnerable to budget decreases from the maximum total of $\$ 305.4$ million.)

- The shaded cell in the next-to-last rov identifies the last funding unit (number 31, AL7) to receive its lowest funding. (In a sense, this funding unit alternative is the least vulnerable.)

- In general, as funding decreases, funding unit alternatives that better satisfy the RASS objectives for WM tend to "retain funding" longer than those that do not satisfy the objectives as well.

- Only one cell is shaded in most rows; however, some rows indicate many changes (e.g., at $\$ 259.7$ million, six cells are shaded).

- Funding unit 31 (AL7) is the most "resilient" because its three changes (from $\mathrm{L}$ to $\mathrm{O}, \mathrm{O}$ to $\mathrm{I}$, and I to $\mathrm{C}$ ) are the last changes suggested by RASS. In fact, this funding unit receives its maximum budget request when the total WM budget is only $3 \%$ of the maximum amount.

- Only one alternative - long range - for funding unit 3 (RL3) was used in the allocation.

- Among funding units with three or more alternaiives, funding unit 19 (CH7) is the first to receive its lowest funded alternative (core in this case) as the WM budget decreases from the maximum amount. This circumstance occurs at the $76 \%$ level for the WM budget.

- Funding unit 5 (RL5) is the first to receive its lowest funded alternative (core) because there is a small difference in utility between its two alternatives, which differ in target-year cost by more than $\$ 2$ million.

- Although in most cases a number of optimal solutions are available among those listed in Table 17, they do not preserve the property described in the third bullet (i.e., for each decrease in funding, one or more funding units receive less money, and the others receive the same amount as in the previous solution).

Table 18 is an example of the type of RASS output available. It focuses on a specific total WM budget ( $\$ 280$ million). A similar table could be constructed for any specific total budget. The table is a partial listing of results, that is, for 4 of the 33 funding units. 
TABLE 18 Selected Details about the Possible Allocation of a $\$ 280$ Million WM Budget (reference substitution rates)

\begin{tabular}{|c|c|c|c|}
\hline $\begin{array}{l}\text { Field Office/Funding } \\
\text { Unit Number and Name }\end{array}$ & Alternative & $\begin{array}{c}\text { Allocation } \\
\left(\$ 10^{6}\right)\end{array}$ & Activity Description \\
\hline $\begin{array}{l}\text { Hanford } \\
\text { RL1, Waste Tank } \\
\text { Ferrocyanide } \\
\text { Stabilization }\end{array}$ & Operations & 19.70 & $\begin{array}{l}\text { Complete upgrades and } \\
\text { FeCN waste testing; } \\
\text { complete safety testing; } \\
\text { no compliance problem }\end{array}$ \\
\hline $\begin{array}{l}\text { RL5, Site Preparation } \\
\text { and Stabilization }\end{array}$ & Core & 0 & $\begin{array}{l}\text { No work; unattractive site; } \\
\text { Occupational Safety and } \\
\text { Health Administration } \\
\text { (OSHA) asbestos violation } \\
\text { (29 CFR 1926.58) }\end{array}$ \\
\hline $\begin{array}{l}\text { RL10, 200-Area } \\
\text { Sanitary Sewer }\end{array}$ & Long range & 0.36 & $\begin{array}{l}\text { Construct new system on } \\
\text { schedule (1999); pump until } \\
\text { new system is in place; no } \\
\text { compliance problem }\end{array}$ \\
\hline $\begin{array}{l}\text { Albuquerque } \\
\text { AL27, LANL, Low- } \\
\text { Level Radioactive } \\
\text { Waste Disposal }\end{array}$ & Operations & 6.64 & $\begin{array}{l}\text { Dispose of } 6,000 \mathrm{~m}^{3} / \mathrm{yr} \\
\text { compliance problem (DOE } \\
\text { Order } 5480.19 \text { ) }\end{array}$ \\
\hline
\end{tabular}

Information in the table includes the amount allocated to each funding unit and a short description of what can or cannot be accomplished. For example, RASS results suggest a $\$ 6.64$ million allocation (the operations alternative) for the Albuquerque funding unit, based on reference substitution rates.

Table 19 presents the information contained in Table 17 in another way. It focuses on the differences between two adjacent rows, which correspond to two "consecutive" total funding amounts analyzed with RASS. As noted earlier, the difference between adjacent rows in Table 17 usually involves only one funding unit. Therefore, it is straightforward to use the RASS results to write down the order in which furding units could receive more funds as total funding increases. The minimum total funding ( $\$ 115.1$ million) is listed at the top of Table 19. RASS results next suggest increasing funding to finance the intermediate alternative (instead of the core alternative) for funding unit 31 , which requires an increase of $\$ 1$ million. This increase is indicated by the only change highlighted in the next-to-last row in Table 17. Thus, the first entry in Table 19 is $31_{\mathrm{I}}$ (funding unit 31 , intermediate). In fact, the first three changes suggested by RASS results involve funding unit 31 (see Table 19, which gives the cumulative WM budget, funding unit change[s], and a short description of the effects of the change). 
TABLE 19 An Alternative Representation of Reference RASS Allocation Result 3 (reference substitution rates)

\begin{tabular}{|c|c|c|}
\hline $\begin{array}{l}\text { Total Cost } \\
\left(\$ 10^{3}\right)\end{array}$ & $\begin{array}{l}\text { Funding } \\
\text { Unit } \\
\text { Change }^{\mathrm{a}}\end{array}$ & Description of Change \\
\hline 115.1 & $-{ }^{b}$ & (All funding units receive the lowest funding.) \\
\hline 116.1 & $31_{\mathrm{I}}$ & $\begin{array}{l}\text { Operate at } 50 \% \text { capacity; comply with Clean Water Act (CWA); meet } \\
\text { Tiger Team milestone }\end{array}$ \\
\hline 119.5 & $31_{0}$ & Operate at $75 \%$ capacity now, $100 \%$ in out-years \\
\hline 119.9 & $31_{L}$ & $\begin{array}{l}\text { Operate at full capacity in all years; meet all Headquarters-tracked } \\
\text { milestones }\end{array}$ \\
\hline \multirow[t]{3}{*}{131.1} & $26_{\mathrm{O}}$ & $\begin{array}{l}\text { Collect and treat LLW and TRU wastes; upgrade equipment; comply } \\
\text { with CWA National Pollution Discharge Elimination System (NPDES) } \\
\text { and RCRA ( } 40 \text { CFR 280) }\end{array}$ \\
\hline & $27 \mathrm{O}$ & $\begin{array}{l}\text { Dispose of all LLW; comply with tribal requirements and DOE } \\
\text { Order } 5820.2 \mathrm{~A}\end{array}$ \\
\hline & $30_{\mathrm{O}}$ & Operate at $100 \%$ capacity; meet CWA, RCRA, and DOE orders \\
\hline 131.5 & $10_{\mathrm{L}}$ & Construct new sewer system; comply with RCRA \\
\hline 151.5 & $8_{0}$ & $\begin{array}{l}\text { Begin construction in target year and continue in out-years; cost } \\
\text { savings in } 1999 \text { because new storage tanks would not be built }\end{array}$ \\
\hline 151.5 & $20_{O}$ & $\begin{array}{l}\text { Begin construction two years earlier; comply with RCRA (land } \\
\text { disposal restrictions [LDRs]) ( } 40 \text { CFR 268) }\end{array}$ \\
\hline 152.0 & $32_{1}$ & Make progress on RCRA violation; ship $50 \%$ of hazardous waste \\
\hline \multirow[t]{2}{*}{159.2} & $12 \mathrm{O}$ & $\begin{array}{l}\text { Make progress on RCRA and Interagency Agreement problems; } \\
\text { process } 65 \% \text { of waste }\end{array}$ \\
\hline & $32 \mathrm{O}$ & $\begin{array}{l}\text { Achieve full compliance (RCRA, DOE Order 5480.19); process all } \\
\text { waste }\end{array}$ \\
\hline 159.7 & $25_{\mathrm{O}}$ & Meet a Tiger Team milestone \\
\hline
\end{tabular}


TABLE 19 (Cont.)

\begin{tabular}{|c|c|c|}
\hline $\begin{array}{l}\text { Total Cost } \\
\left(\$ 10^{3}\right)\end{array}$ & $\begin{array}{l}\text { Funding } \\
\text { Unit } \\
\text { Change }^{\mathrm{a}}\end{array}$ & Description of Change \\
\hline \multirow[t]{5}{*}{189.8} & $2_{\mathrm{O}}$ & $\begin{array}{l}\text { Make significant progress on Tri-Party Agreement regarding RCRA } \\
\text { requirements for TSD ( } 40 \text { CFR 264) and LDRs ( } 40 \text { CFR 268); prepare } \\
\text { to begin construction of Waste Receiving and Processing Module } 1 \text { in } \\
\text { two years }\end{array}$ \\
\hline & $4_{I}$ & $\begin{array}{l}\text { Make significant progress on Tri-Party Agreement regarding DOE } \\
\text { Order } 6430 . \mathrm{A} 1,40 \text { CFR } 61 \text { (National Emission Standards for } \\
\text { Hazardous Air Polluntants), and } 10 \text { CFR } 72 \text { (spent fuel storage); } \\
\text { process all waste }\end{array}$ \\
\hline & $23_{I}$ & $\begin{array}{l}\text { Make progress on } 40 \text { CFR } 761 \text { (Toxic Substance Control Act [TSCA]) } \\
\text { and } 40 \text { CFR } 122 \text { (CWA NPDES) }\end{array}$ \\
\hline & ${ }^{26}{ }_{\mathrm{L}}$ & $\begin{array}{l}\text { Attain full compliance; upgrade stack monitoring system; implement } \\
\text { storage tank testing program }\end{array}$ \\
\hline & $33_{\text {I }}$ & $\begin{array}{l}\text { Make some progress on RCRA and DOE Order } 5480.19 \text {; begin } \\
\text { processing waste }(\approx 60 \%) \text { and investing in worker } S \& H \text { programs }\end{array}$ \\
\hline \multirow[t]{3}{*}{195.7} & $11_{I}$ & $\begin{array}{l}\text { Make progress on } \mathrm{RCRA} \text { violation and DOE Order } 5420.2 \mathrm{~A} \text {; ship low- } \\
\text { level mixed waste }\end{array}$ \\
\hline & $23_{\mathrm{O}}$ & Full compliance; full operations; meet all milestones \\
\hline & $24_{\mathrm{L}}$ & Full compliance in out-year 2 ; full operations; meet all milestones \\
\hline 195.7 & $13_{O}$ & Meet all Tiger Team milestones \\
\hline 197.8 & $33_{\mathrm{O}}$ & $\begin{array}{l}\text { Improve progress on RCRA and DOE Order } 5480.19 \text {; process virtually } \\
\text { all waste; increase investment in worker S\&H programs; plan for } \\
\text { upgrade }\end{array}$ \\
\hline 198.3 & $15 \mathrm{O}$ & $\begin{array}{l}\text { Attain full compliance with CWA NPDES (40 CFR 122.26) and New } \\
\text { Jersey Administrative Cr,de } 7: 14 A-3.8\end{array}$ \\
\hline \multirow[t]{3}{*}{242.0} & $6_{\mathrm{O}}$ & $\begin{array}{l}\text { Attain full compliance; full operations; vigorous investment in worker } \\
\text { S\&H programs }\end{array}$ \\
\hline & $21_{I}$ & $\begin{array}{l}\text { Make progress on CWA NPDES ( } 40 \text { CFR 122); begin monitoring liquid } \\
\text { effluents }\end{array}$ \\
\hline & $25_{L}$ & $\begin{array}{l}\text { Fully implement Waste Isolation Pilot Plant waste acceptance criteria } \\
\text { program; construct shafts for storage of remote-handled TRU waste; } \\
\text { fully implement quality assurance/quality control and conduct of } \\
\text { opei ations programs per DOE orders; address corrosion of buried } \\
\text { drums }\end{array}$ \\
\hline
\end{tabular}


TABLE 19 (Cont.)

\begin{tabular}{|c|c|c|}
\hline $\begin{array}{l}\text { Total Cost } \\
\left(\$ 10^{3}\right)\end{array}$ & $\begin{array}{l}\text { Funding } \\
\text { Unit } \\
\text { Change }^{a}\end{array}$ & Description of Change \\
\hline $\begin{array}{l}242.0 \\
\text { (Cont.) }\end{array}$ & $33_{\mathrm{L}}$ & $\begin{array}{l}\text { Full compliance with RCRA and DOE Order } 5480.19 \text {; construct a new } \\
\text { building with better hazardous waste storage features; benchscale } \\
\text { treatment of hazardous waste; ship all hazardous waste off-site }\end{array}$ \\
\hline \multirow[t]{6}{*}{259.7} & $1_{1}$ & $\begin{array}{l}\text { Delays decreased by one yeal (upgrading instrumentation, } \\
\text { interpreting sample data, and completing program and transferring } \\
\text { responsibility to operations); improved compliance with RCRA and } \\
\text { DOE orders }\end{array}$ \\
\hline & $4_{0}$ & $\begin{array}{l}\text { Full compliance with Tri-Party Agreement regarding DOE } \\
\text { Order } 6430 . \mathrm{A} 1,40 \text { CFR } 61 \text { (NESHAPs), and } 10 \text { CFR } 72 \text { (spent fuel } \\
\text { storage) }\end{array}$ \\
\hline & $9_{\mathrm{O}}$ & Full compliance with Tri-Party Agreement and RCRA (40 CFR 265) \\
\hline & $12_{\mathrm{L}}$ & Full compliance with RCRA and DOE Order $5420.2 \mathrm{~A}$ \\
\hline & $17_{\mathrm{O}}$ & $\begin{array}{l}\text { Full compliance with RCRA ( } 40 \text { CFR } 262,265 \text { ) and TSCA ( } 40 \text { CFR } \\
761 \text { ); full operations }\end{array}$ \\
\hline & ${ }^{2{ }^{9}} \mathrm{~L}$ & $\begin{array}{l}\text { Full compliance with RCRA ( } 40 \text { CFR } 265.173 \text { ) in out-year } 2 \text { by } \\
\text { beginning demolition now and completing work in out-year } 2\end{array}$ \\
\hline 259.9 & $22_{\mathrm{O}}$ & Full compliance (Tiger Team milestone); full operations \\
\hline 261.1 & $19_{\mathrm{I}}$ & $\begin{array}{l}\text { Ship } 50 \% \text { of LLW off-site; full compliance with DOE Order } 5480.23 \\
\text { (safety analysis report [SAR]) and RCRA ( } 40 \text { CFR 261, 262) }\end{array}$ \\
\hline 261.5 & $21_{\mathrm{O}}$ & Full compliance with CWA NPDES (40 CFR 122) \\
\hline 264.1 & $28_{\mathrm{L}}$ & $\begin{array}{l}\text { Full compliance with CWA and DOE Order } 5480.4 \text {; meet all Five-Year } \\
\text { Plan milestones }\end{array}$ \\
\hline 270.5 & $18_{0}$ & $\begin{array}{l}\text { Full compliance with RCRA ( } 40 \text { CFR } 262,265,268,270 \text { ), CERCLA } \\
\text { (40 CFR } 300 \text { ), and Interagency Agreement }\end{array}$ \\
\hline \multirow[t]{2}{*}{279.6} & $1_{\mathrm{O}}$ & $\begin{array}{l}\text { Improved progress on compliance issues; further reduce impact on } \\
\text { public safety and health }\end{array}$ \\
\hline & $14_{\mathrm{O}}$ & $\begin{array}{l}\text { Full compliance with DOE Order 5820.2A; meet Tiger Team } \\
\text { milestone; full operations }\end{array}$ \\
\hline 280.2 & $16_{\mathrm{O}}$ & $\begin{array}{l}\text { Full compliance with RCRA ( } 40 \text { CFR } 262,255,268,270 \text { ), CERCLA } \\
\text { (40 CFR } 300 \text { ), and Interagency Agreement }\end{array}$ \\
\hline
\end{tabular}


TABLE 19 (Cont.)

\begin{tabular}{ccl}
$\begin{array}{c}\text { Total Cost } \\
\left(\$ 10^{3}\right)\end{array}$ & $\begin{array}{c}\text { Funding } \\
\text { Unit } \\
\text { Change }\end{array}$ & \\
\hline 298.1 & $1_{\mathrm{L}}$ & $\begin{array}{l}\text { Minimum delays in achieving full compliance; minimize impact on } \\
\text { public safety and health }\end{array}$ \\
& $7_{\mathrm{L}}$ & Full operations; vigorous worker S\&H program \\
301.2 & $27_{\mathrm{L}}$ & Full compliance (DOE orders 5820.2A and 5480.19) \\
303.3 & $11_{\mathrm{O}}$ & $\begin{array}{l}\text { Full compliance with DOE Order 5420.2A and RCRA; meet all Five- } \\
\text { Year Plan milestones }\end{array}$ \\
305.4 & $5_{\mathrm{L}}$ & $\begin{array}{l}\text { Full compliance with OSHA (29 CFR 1926.58, asbestos); characterize, } \\
\text { demolish, and clean up orphan buildings }\end{array}$ \\
& $19_{\mathrm{L}}$ & $\begin{array}{l}\text { Full compliance with DOE Order 5480.23 (SAR) and RCRA (40 CFR } \\
\text { 261, 262); meet all Five-Year Plan milestones; full operations }\end{array}$ \\
\hline
\end{tabular}

a The number given is the national funding unit number. The subscript indicates the alternative: $\mathrm{I}=$ intermediate; $\mathrm{O}=$ operations; and $\mathrm{L}=$ long-range.

b Not applicable.

For example, the first increase enables funding unit 31 to operate at the $50 \%$ level (i.e., treat, store, and dispose of one-half of the waste scheduled), meet provisions of the Clean Water Act, and meet a Tiger Team milestone. The second increase (from $31_{\mathrm{I}}$ to $31_{\mathrm{O}}$ ) enables full treatment and operations at the $75 \%$ level for storage and disposal activities. The last increase (from $31_{O}$ to $31_{L}$ ) enables full operations for all activities, full and rapid compliance for all radioactive waste streams, and achievement of all Headquarters-tracked milestones.

The fourth increase (of $\$ 11.2$ million to a total of $\$ 131.1$ million) enables funding of alternatives $26_{\mathrm{O}}, 27_{\mathrm{O}}$, and $30_{\mathrm{O}}$ (instead of the core alternative for each). This funding increase enables a higher degree of compliance and a higher level of operation at each funding unit. Subsequent increases in total EM funding enable improved performance among the funding units in the order indicated in Table 19. The last row in Table 19, which shows the largest total WM budget, indicates that funding unit 19 is the last one to receive its largest request. 


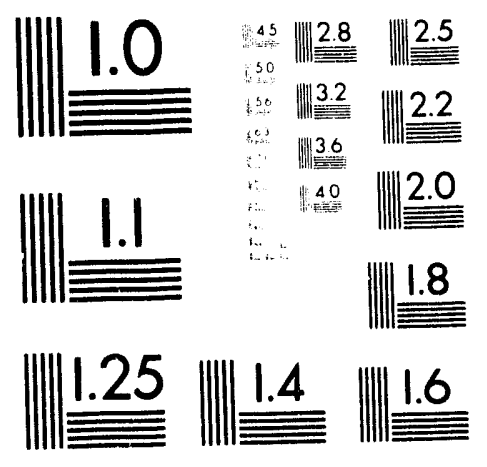



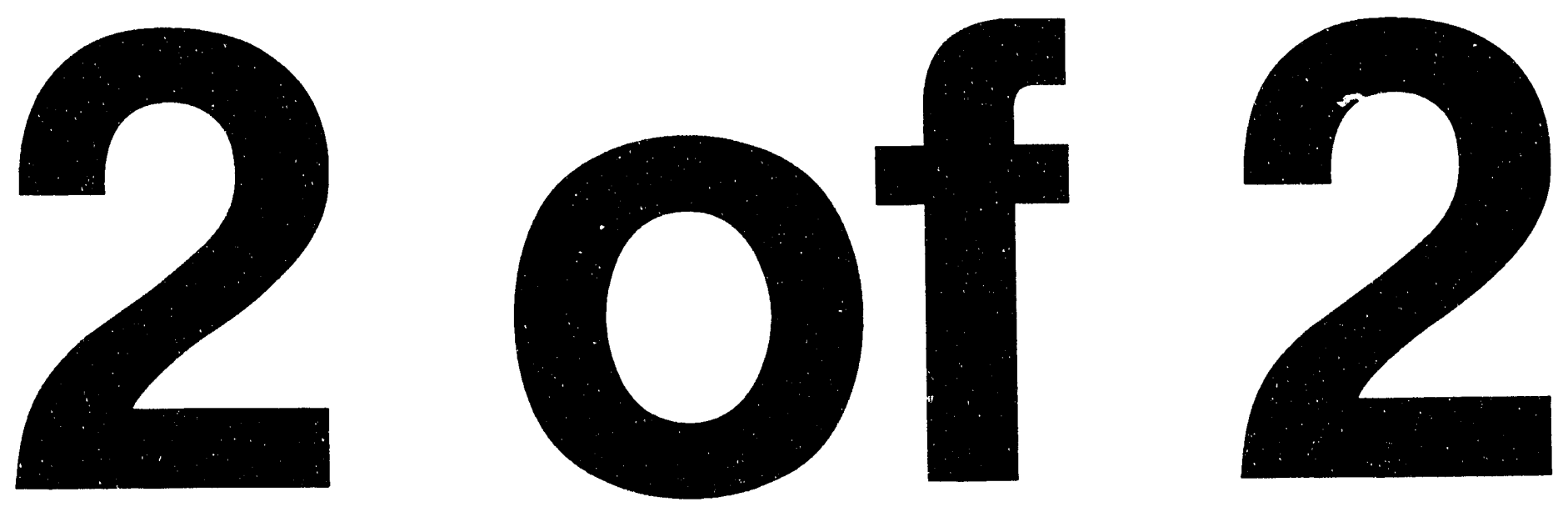


\subsubsection{Answers to "What If?" Questions}

RASS will make it possible to obtain a quick answer to what if questions such as:

- What compliance "problems" will be solved if the total WM budget is increased by $\$ 25$ million?

- What compliance problems will not be solved if the total WM budget is decreased by $\$ 25$ million?

- What are the implications of a very small WM budget on public (or occupational) safety and health?

- What are the implications of a large WM budget on public (or occupational) safety and health?

- How much more waste can be processed if funding is increased by $\$ 50$ million?

- What is the effect of a small (or large) WM budget on system cost?

The remainder of Section 5 analyzes a few what if questions.

The existence of compliance problems is indicated in Figure 11, which is a plot of "equivalent level-H counts" ${ }^{8 n}$ versus WM budget. This figure is based on the solutions listed in Table 17. All compliance issues are included for all years for which the RASS pilot study has data. As expected, equivalent level-H counts decrease as funding increases. The "worst" compliance situation occurs when minimum funding is provided, and the "best" compliance situation occurs when maximum funding is provided. This figure can be used to answer the first what if question listed above. For example, there are about 125 equivalent level-H counts at a total WM budget of $\$ 150$ million. An additional $\$ 25$ million will reduce this count to about 80. A reduction of $\$ 25$ million will increase this count to about 145 . The effect of a $\$ 25$ million increase (or decrease) diminishes at budgets higher than $\$ 150$ million.

8 Equivalent count is an overall measure of the number of compliance problems. It takes into account the fact that the seriousness of the different levels varies, that a particular compliance level may occur many times, and that uncertainty may be present. For example, a level-B outcome is, in a sense, about one-fifth as serious as a level-H outcome. Thus, an equivalent level-H count of 2 would result from two level-H problems, or one level-H and five level-B problems, and so on. In addition, an equivalent level-H count of 1.2 would result from one level- $\mathrm{H}$ and a 0.2 probability of a second level-H count (and 0.8 probability of level A). 


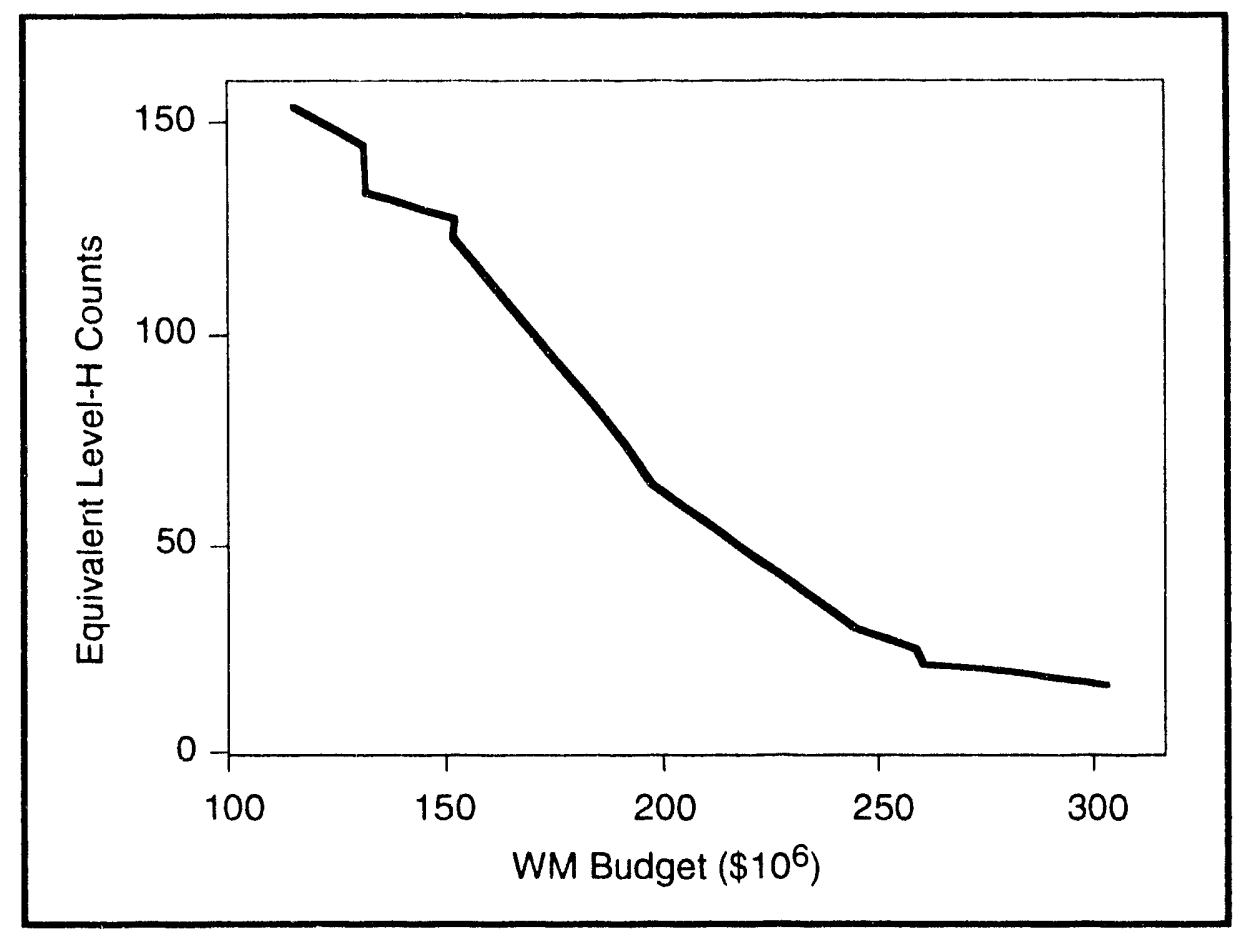

FIGURE 11 Equivalent Level-H Counts in All Years for the Compliance Objective versus Total WM Budget (reference substitution rates)

Tables can be used to answer more specific what if questions. For example, if the WM budget were increased by $\$ 21$ million (from $\$ 280.2$ million to $\$ 301.2$ million), where would RASS recommend allocating the additional funds and what would WM achieve programmatically? Table 20 addresses this question and indicates the following:

- Only four funding units are affected (two at Hanford, one at Rocky Flats, and one at Albuquerque). As expected, all receive increases in funding.

- The additional funds make it possible to fund the long-range alternative at three of the funding units.

- The benefits of the additional funds include reduced risk to the public, additional disposal capacity, increased compliance with RCRA and DOE orders, and elimination of the need to upgrade storage and treatment facilities.

While Table 20 addresses the implications of a budget increase, Table 21 addresses the compliance implications of a budget decrease of $\$ 25.8$ million (from $\$ 305.4$ million to $\$ 279.6$ million). Such a budget reduction would affect seven funding units. Because $\$ 305.4$ million is the sum of the larg'st funding requests from each funding unit, this reduction necessarily results in reduced performance with respect to many objectives, one of 


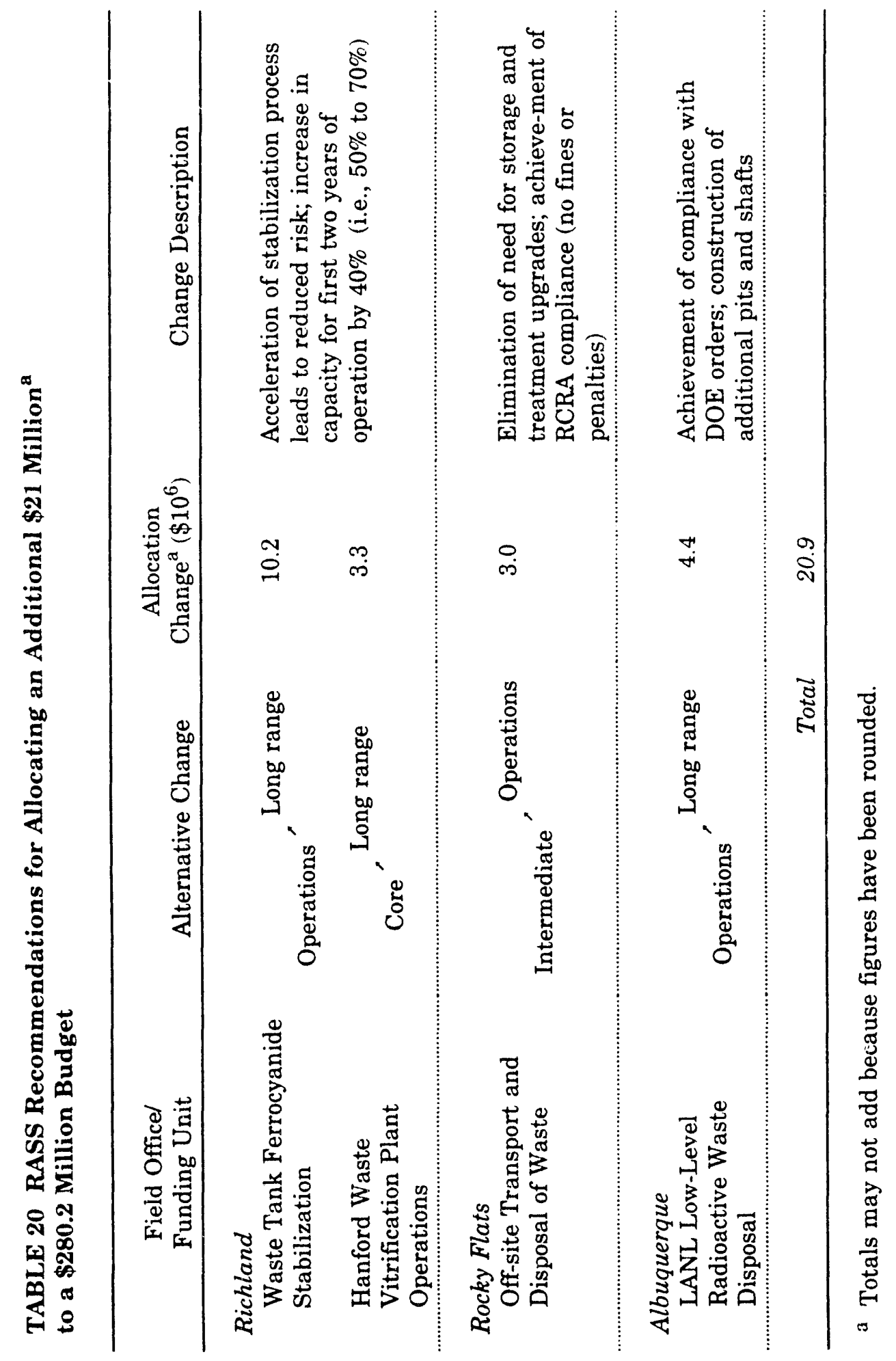




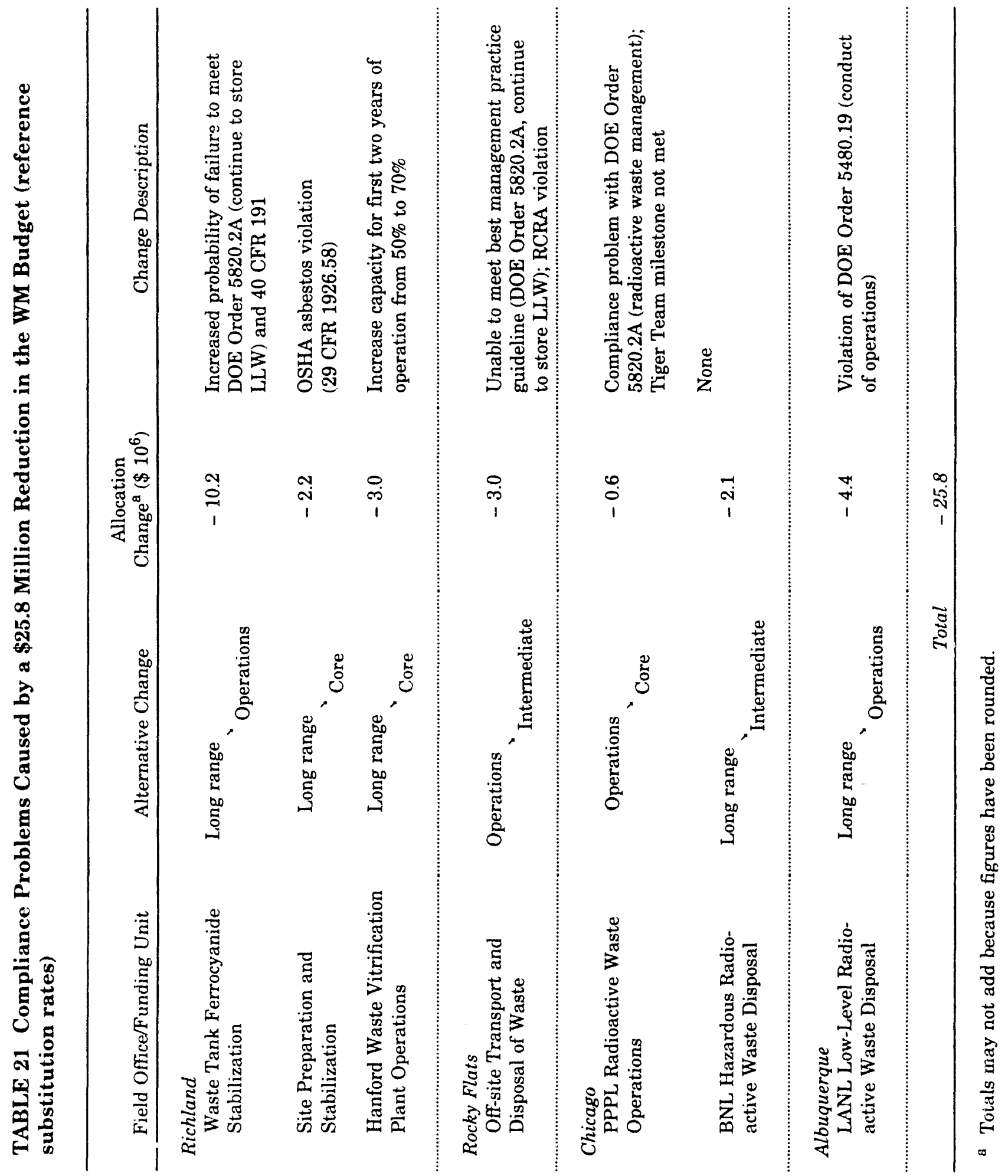


which involves compliance. Performance with respect to compliance would be affected at five of these funding units. The compliance problems that would arise involve:

- Increased probability of failure to meet a DOE order;

- Failure to meet DOE orders, OSHA regulations, or RCRA regulations; and

- Failure to meet Tiger Team milestones.

Another example of the type of results that RASS can produce is given in Figure 12, which shows four histograms (one for each of four total WM budgets) that depict the frequency of occurrence of each level of compliance. ${ }^{9}$ Fractional counts are possible if probabilities are involved. ${ }^{10}$ The histograms show how the distribution of compliance problems changes as funding changes: generally, few problems are present at maximum funding (indicated at the left of the figure), and many different problems are present at minimum funding (indicated at the right of the figure). For example, maximum funding shows one level-D (violation of a mandatory standard) count and about six level-E (request for an accommodation that leads to a negotiated agreement) counts. When WM funding is $\$ 242$ million (the $67 \%$ level), level-B (nonconformity with a DOE reference standard) and level-C (delays in meeting a Tiger Team milestone) counts appear, the numbers of level-D and level-E counts increase, and level-G and level-H counts appear. In fact as WM funding decreases, the counts generally increase rather steadily. These characteristics are also observable in the plot of equivalent level-H counts versus funding (Figure 11). Figures 11 and 12 show that, even at the maximum budget, some compliance problems remain.

Figures 13-17 show other examples of results that RASS can produce. Figure 13 is a plot of total equivalent fatalities (public and occupational) versus WM budget. The term "equivalent fatalities" is used to indicate that morbidity (person-days lost) is converted to equivalent fatalities by a conversion factor (6,000 person-days lost is equivalent to one fatality). The range of equivalent fatalities (6.6-8.8) includes impacts for all years included in the RASS pilot study. The $y$ axis is scaled over this range. The minimum for total equivalent fatalities occurs at the minimum WM budget, the maximum occurs at about $\$ 260$ million, and the number at the maximum budget is nearly equal to that at the minimum budget.

The shape of the plot in Figure 13 is explained in Figures 14 and 15, which are plots of equivalent public and equivalent occupational fatalities versus total WM budget, respectively. The minimum public impact shown in Figure 14 occurs at the maximum budget. At this budget, the principal impact on the public is due to accidents that involve

9 The compliance scale is defined in Table 2.

${ }^{10}$ For example, if it is equally likely that the compliance outcome will either be level $\mathrm{B}$ or level $\mathrm{C}$ for a particular alternative, the count will be 0.5 for level B and 0.5 for level $C$. 


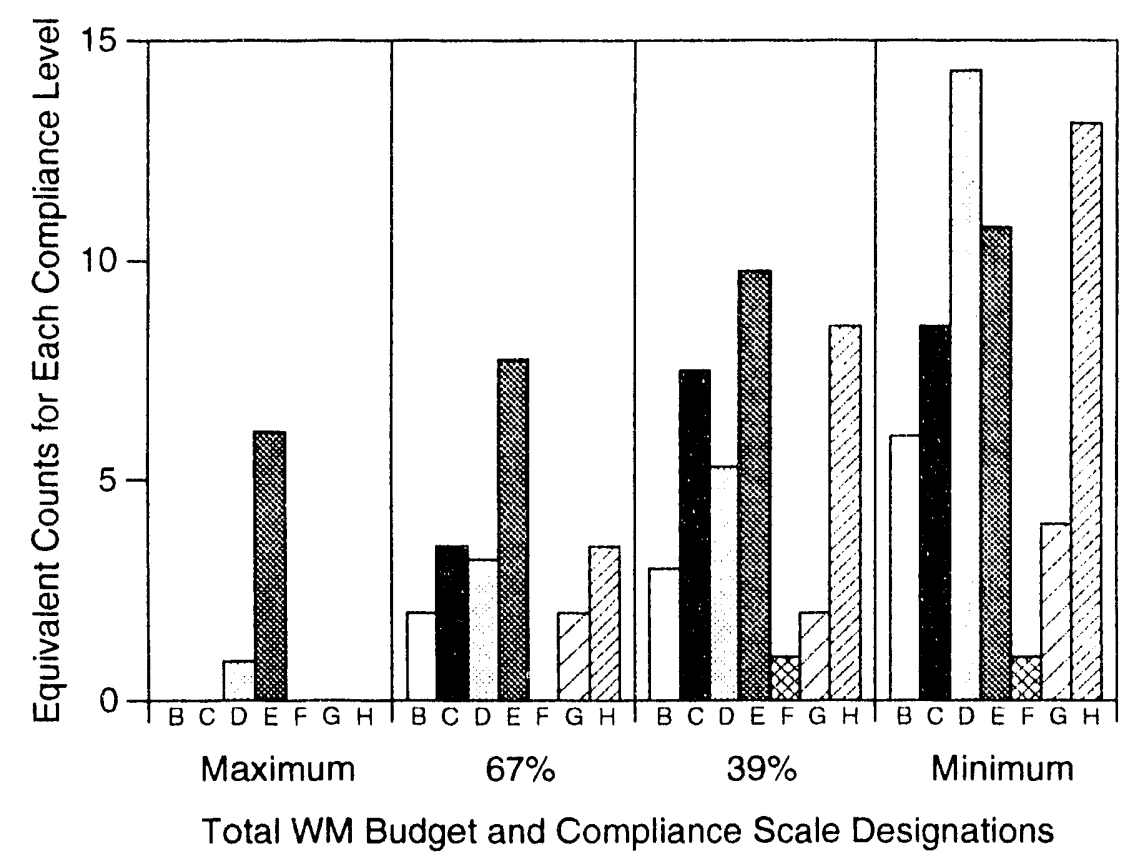

FIGURE 12 Histograms for Equivalent Counts in the Target Year for Each Compliance Level versus Four Total WM Budgets (reference substitution rates; refer to the compliance scale in Table 2 for definitions of levels B-H)

transport of wastes. The impacts at the minimum budget are primarily due to exposures to radiation or carcinogenic substances (via air or water pathways) and partly to transportation accidents. At the maximum budget, transportation accidents dominate the calculation. The peak at about $\$ 260$ million occurs because transportation impacts increase faster than air and water impacts decrease. Most of the air and water impacts are attributable to funding unit 1 (RL1, Waste Tank Ferrocyanide Stabilization), and this funding unit does not receive higher funding until the total WM budget exceeds $\$ 250$ million. In Figure 15 , occupational equivalent fatalities increase steadily as budgets increase, more waste is handled, and more exposures occur.

Throughput (a measure of the amount of waste that is treated, stored, or disposed of) versus total WM budget is plotted in Figure 16. The unit of measure is equivalent cubic meters of low-level waste. ${ }^{11}$ The range on this measure is 214 to $589 \times 10^{-6} \mathrm{~m}^{3}$ of $\mathrm{LLW}$.

11 Similar to other conversions to equivalent units, treating $1 \mathrm{~m}^{3}$ of transuranic waste is equivalent to treating about $5 \mathrm{~m}^{3}$ of low-level waste; treating $1 \mathrm{~m}^{3}$ of high-level waste is equivalent to treating about $8 \mathrm{~m}^{3}$ of low-level waste; and so on. The conversion rates used in the RASS pilot study are preliminary and will be updated for the full-scale test. 


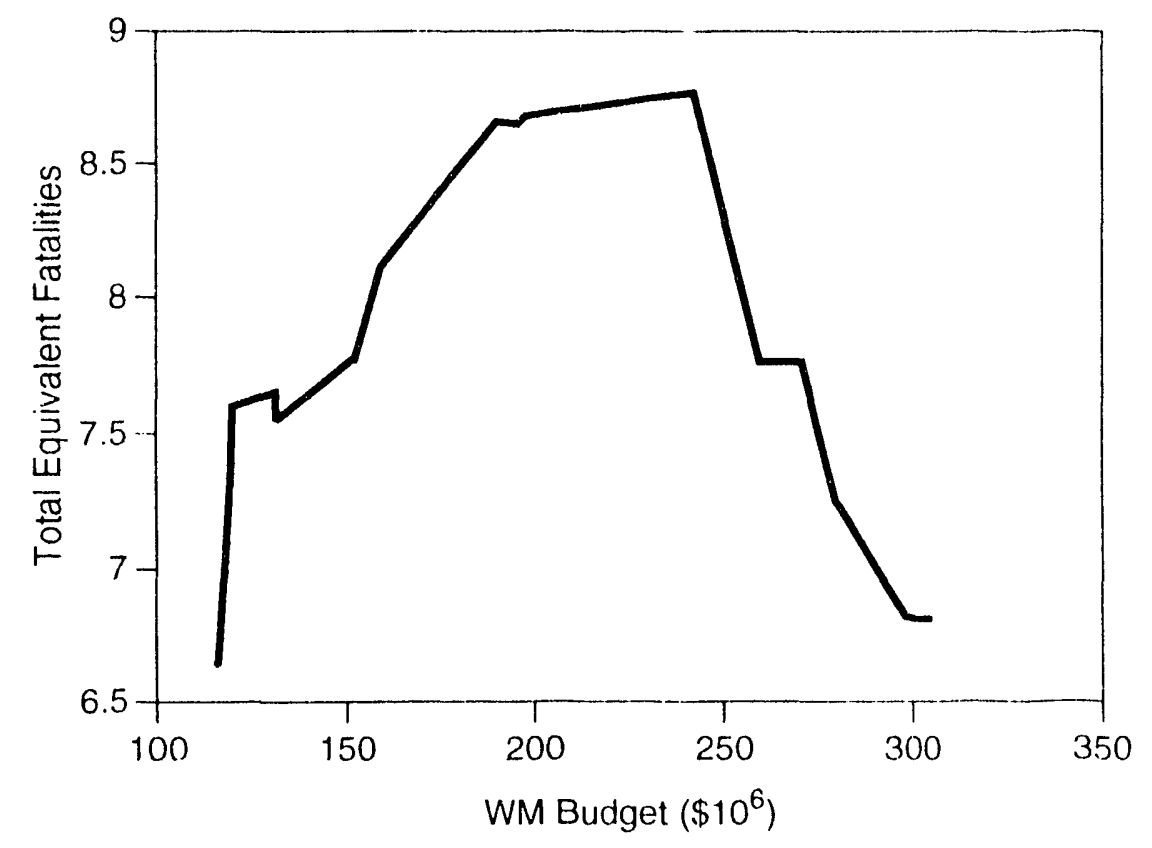

FIGURE 13 Total Equivalent Fatalities versus WM Budget (reference substitution rates)

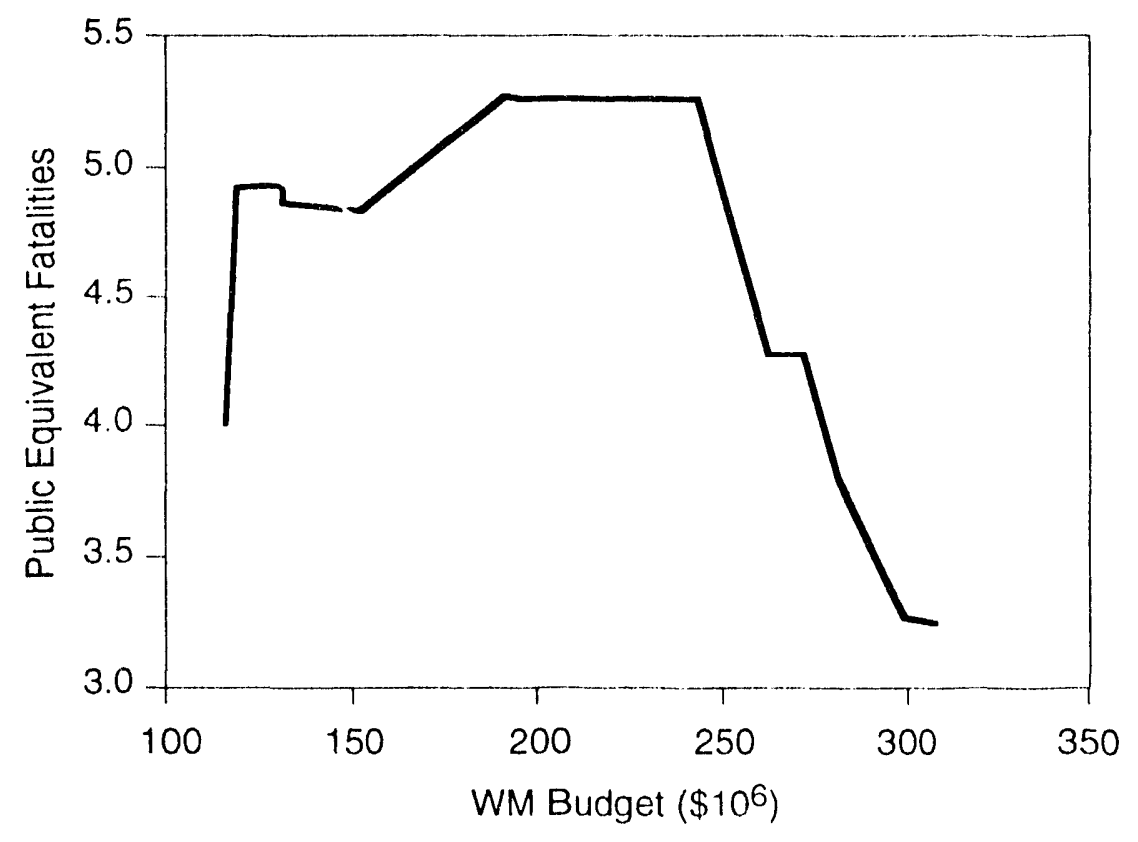

FIGURE 14 Public Equivalent Fatalities versus WM Budget (reference substitution rates) 


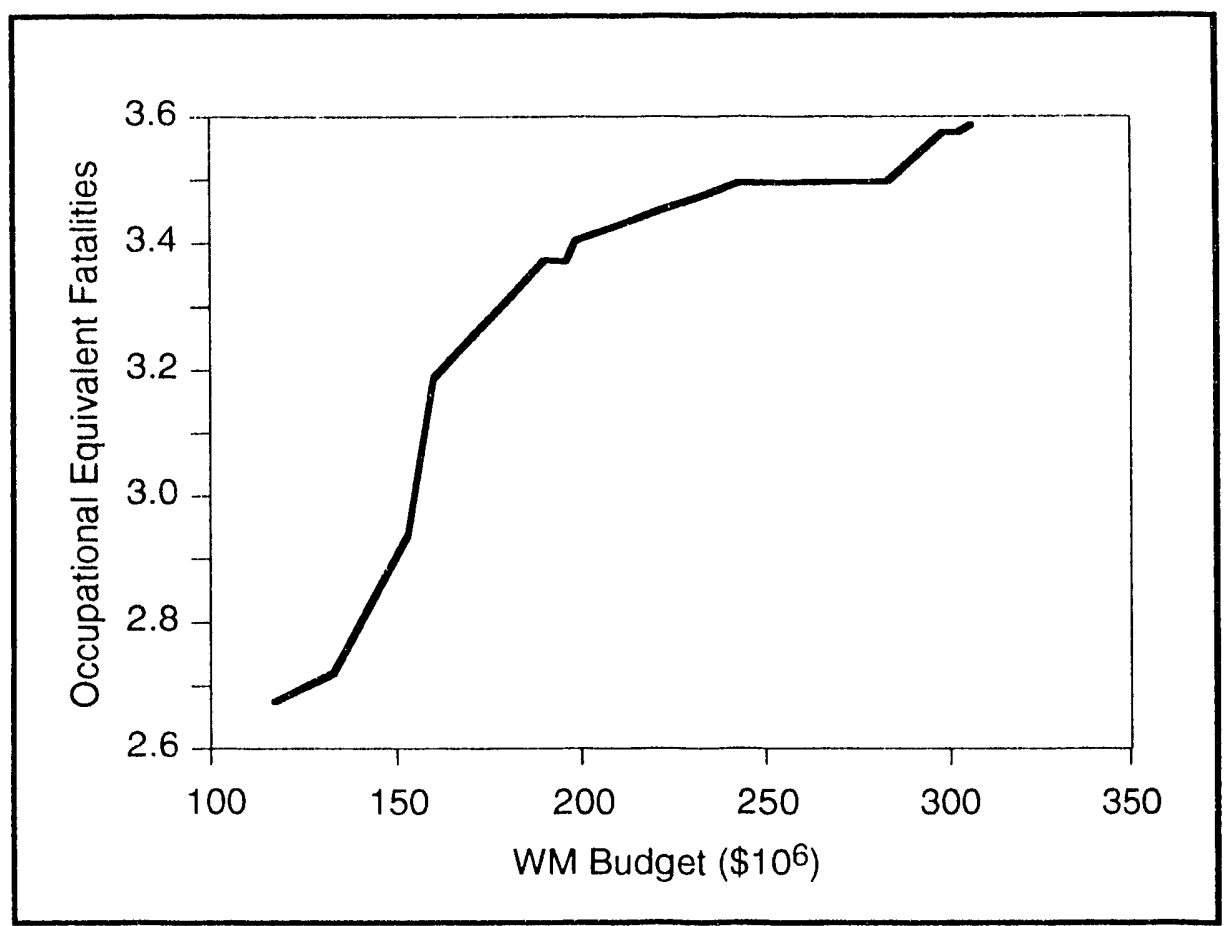

FIGURE 15 Occupational Equivalent Fatalities versus WM Budget (reference substitution rates)

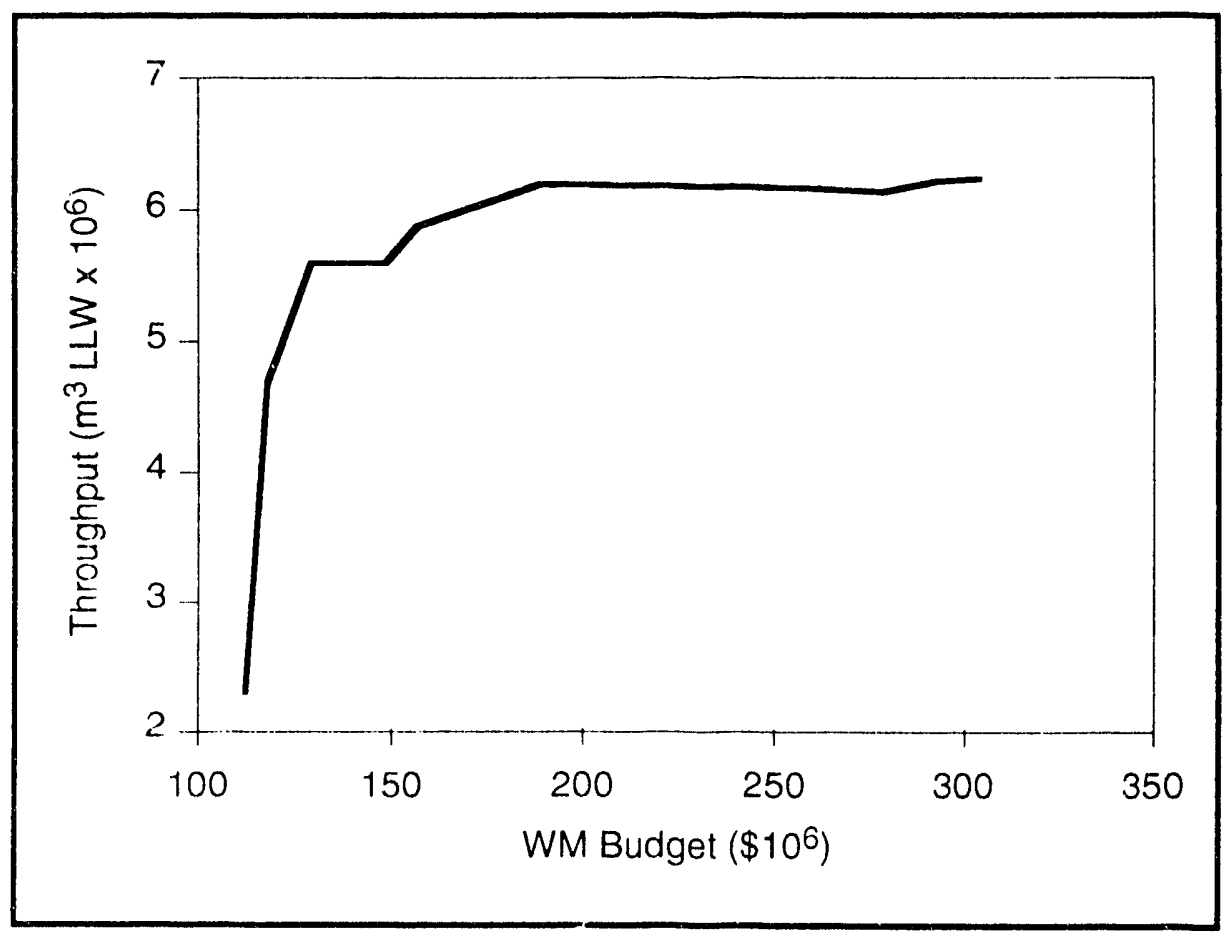

FIGURE 16 Throughput in Terms of Equivalent Volume of LowLevel Waste versus WM Budiget (reference substitution rates) 


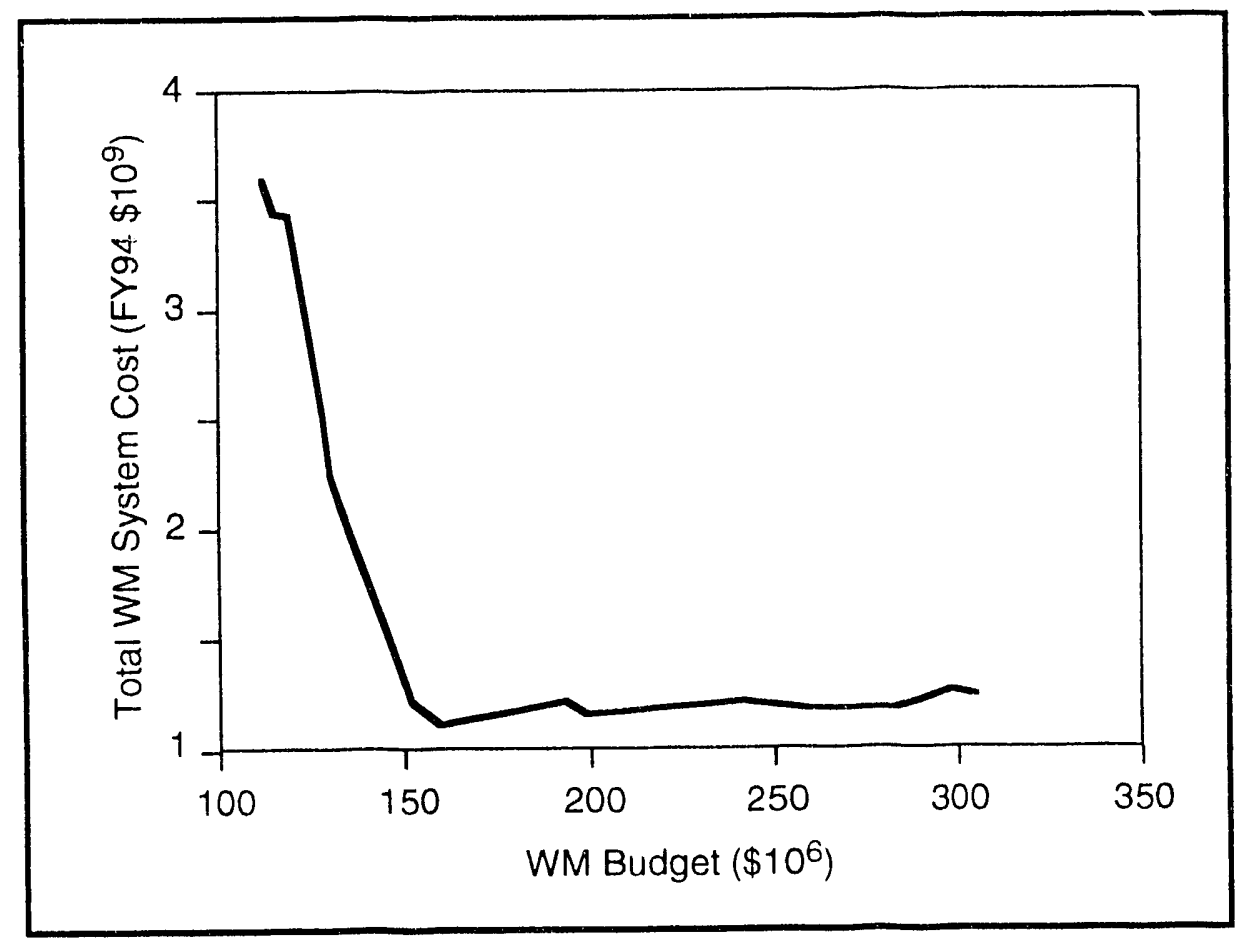

\section{FIGURE 17 System Cost versus WM Budget (reference substitution rates)}

This measure sharply increases as funding increases above the minimum level because a tremendous increase in throughput ${ }^{12}$ occurs at funding unit 31 (AL7, Mound Plant Radioactive Waste Management) as funding increases at this funding unit.

Figure 17 is a graph of WM system cost versus total WM budget. As defined in Section 2.2.4, WM system cost for a funding unit has two components: annual budget requests and estimated cost savings ${ }^{13}$ that occur at other funding units. The unit of measure for WM system cost is dollars (present value of all budget requests, cost savings, and cost penalties for all years), and the range is $\$ 1.1$ billion- $\$ 3.6$ billion. At the minimum WM budget, WM system cost is extremely high because of large cost penalties associated with facility closure, fines, and so on. When most of these problems are solved (at a WM budget of about $\$ 160$ million), WM system cost is at a minimum. As WM budget increases above

12 At the November 9-10, 1992, meeting of DOE Headquarters and field office personnel, it was determined that the scoring for this funding unit was not correct (the entries for waste processed were too high). It was decided to leave these entries "as is" because of the effort required to modify existing analyses, graphics, and documentation. However, it is important to note that it is a minor matter to make the change in the RASS database and redo the allocations. It is planned that a future version of the RASS computer program will quickly anù easily produce high-quality graphs of the sort presented here.

13 This notion has been expanded to account for cost penalties (e.g., fines). 
$\$ 160$ million, WM system cost increases, but at a fairly slow rate. The value of a WM budget greater than $\$ 160$ million is in addressing the other RASS objectives for WM.

\subsection{DIFFERENT PERSPECTIVES FOR RASS ANALYSIS}

The reference substitution rates were assessed before the RASS pilot study. During the pilot study, five individuals were interviewed (two DOE field office staff, a DOE contractor, a regional EPA staff member, and a member of an environmental group). These persons provided WM with their perspectives on the RASS objectives. The reference substitution rates were also modified to reflect increased emphasis on the compliance and S\&H objectives. This section examines a few similarities, differences, and implications of these perspectives.

The reference set of substitution rates is denoted $1 \mathrm{R}$, the compliance-emphasized set is $1 \mathrm{C}$, the $\mathrm{S} \& \mathrm{H}$-emphasized set is $1 \mathrm{~S}$, and the remaining sets are 2 through 6 . All of the substitution rates are listed in Table 22 . For set $1 \mathrm{C}$, the value of a shutdown is $\$ 250$ million, which is the substitution rate for perspective 5 . The values assigned to fatalities were multiplied by 10 to obtain set $1 \mathrm{~S} .{ }^{14}$ Shading indicates the differences between set $1 \mathrm{R}$ and sets $1 \mathrm{C}$ and $1 \mathrm{~S}$.

The variation (difference between the largest and smallest substitution rates) is large for most measures. The smallest variations are for $\mathrm{S} \& \mathrm{H}$ programs expenditures and capacity/throughput to be met; the largest variation is for new capacity status. Following are other observations about the different substitution rates:

- By definition, $\$ 1$ of WM system cost is valued at $\$ 1$ in all sets of substitution rates.

- The smallest substitution rate for the compliance measure is $\$ 350,000$. This amount is, in a sense, a measure of what individual 2 is "willing to pay" to avoid a compliance-related facility shutdown. The largest substitution rate is $\$ 250$ million (perspective 5 ). The ratio of the largest and smallest substitution rates is greater than 700 to 1 .

- Two of the six individuals (perspectives 2 and 4) assigned equal substitution rates to public and occupational fatalities. Individuals 3 and 5 distinguished between fatalities resulting from air and water pathway exposures, and fatalities resulting from transportation accidents.

${ }^{14}$ Of the six assessments, set $1 \mathrm{R}$ has the highest substitution rates for fatalities; multiplying by 10 places greater emphasis on the S\&H objective. 


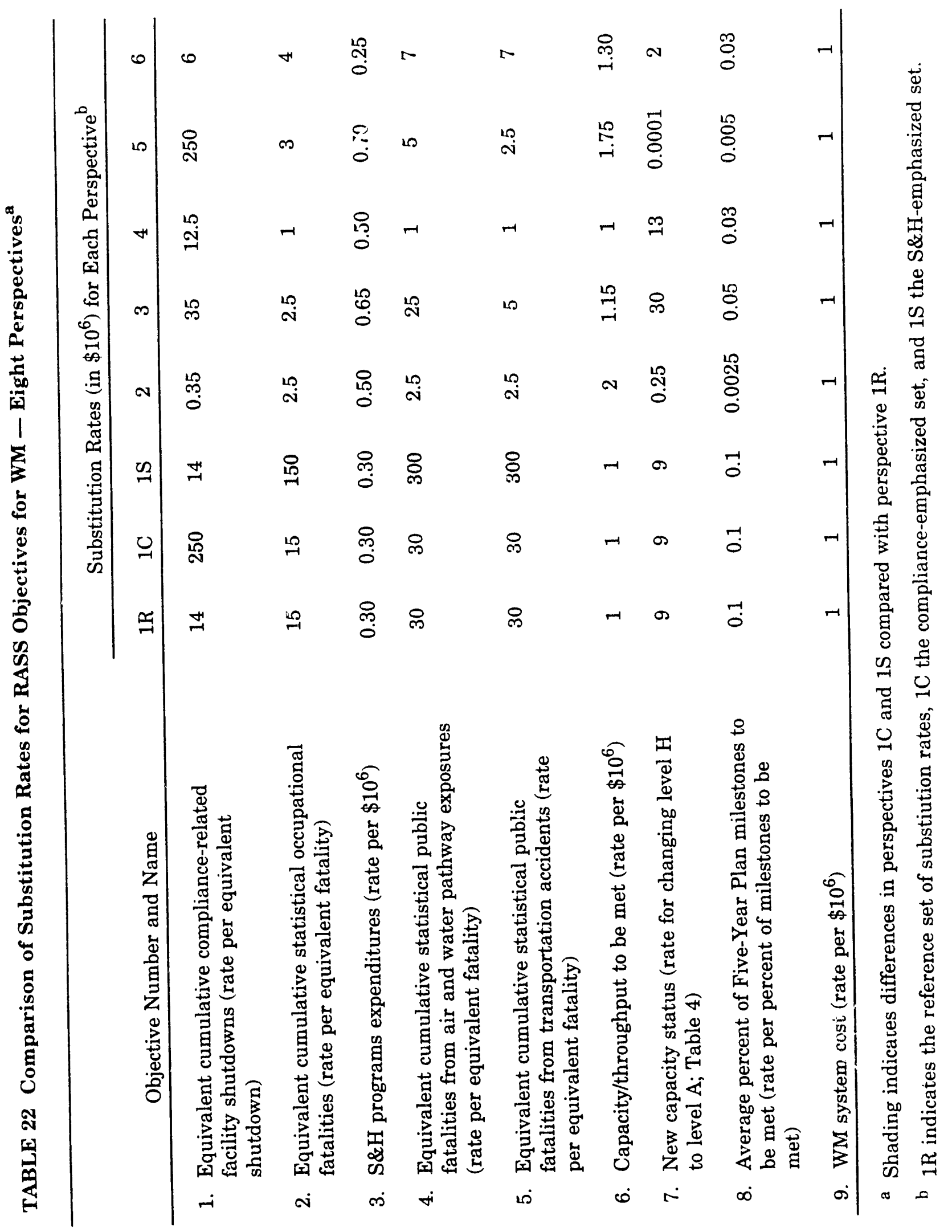


- Excluding perspective $1 \mathrm{~S}$, the ratios of the largest and smallest substitution rates are 15 to 1 for occupational fatalities and 30 to 1 for public fatalities. (The substitution rates for perspective $1 \mathrm{~S}$ were set to test the sensitivity of the reference substitution rates.)

- All individuals judged that the S\&H programs expenditures (those costs in addition to expenditures required to meet laws, regulations, treaties, agreements, and orders) are not cost-effective and assigned substitution rates that were less than $\$ 1$ per dollar requested. The ratio of the largest and smallest substitution rates is about 2 to 1 .

- Two individuals judged that $\$ 1$ of waste managed was equivalent to $\$ 1$ of EM system cost. The other four individuals judged that $\$ 1$ of waste managed was worth more than $\$ 1$ of WM system cost. Individual 2 assigned the highest substitution rate $-\$ 2$ per dollar of waste managed.

- The substitution rate for new capacity status is a measure of the "willingness to pay" to eliminate a 1-yr delay for a project scheduled to be completed in the target year. Judgments about the substitution rate for this measure varied enormously - from $\$ 100$ by individual 5 to $\$ 30$ million for individual 3, which is a ratio of 300,000 to 1 .

- The substitution rates for Headquarters-tracked Five-Year Plan milestones varied from $\$ 10$ million (for perspective $1 \mathrm{R}$ ) to $\$ 250,000$ (for perspective 2), which is a ratio of 40 to 1 . This substitution rate is a measure of the willingness to pay to meet all milestones rather than miss all milestones.

RASS was used to investigate the implications of these differing perspectives. The analysis presented in Section 5.2 could have been repeated for each of the perspectives, but the number of results would be overwhelming. Instead, two illustrations are given - one involves equivalent level-H counts (which address compliance-related facility shutdowns); the other involves funding levels at each of the field offices.

Figure 18 is a plot of equivalent level-H counts (for all years in the RASS pilot study database) versus total WM budget for all eight utility functions. This figure has three plots that summarize results for all eight perspectives:

- Perspective 5 (which is similar to perspective $1 \mathrm{C}$ because both assigned $\$ 250$ million per compliance-related facility shutdown for the compliance objective) causes the equivalent level-H count to decrease most rapidly as the total WM budget increases. (This perspective serves, in a sense, as a "lower bound" for all results.) 


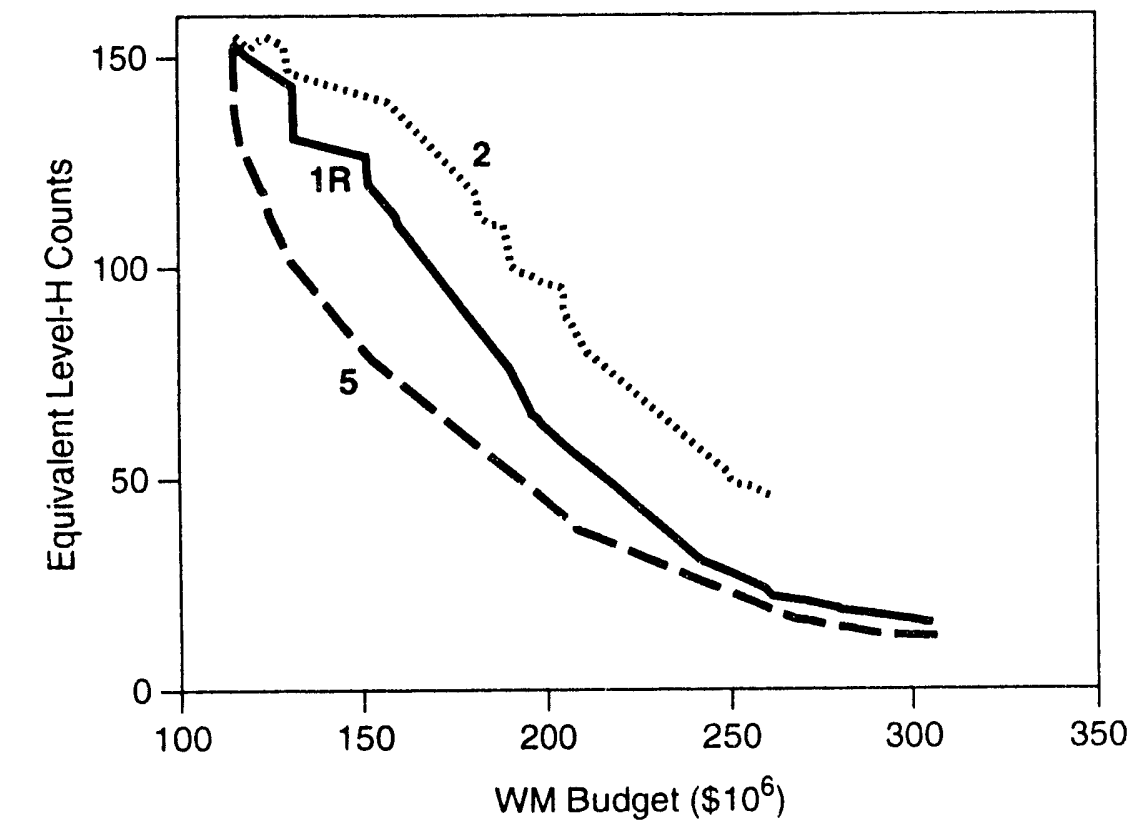

FIGURE 18 Equivalent Level-H Counts versus WM Budget for Three Representative Perspectives

- Perspective 2 shows the slowest rate of decrease in the equivalent level-H measure as funding increases because only $\$ 350,000$ was assigned per compliance-related facility shutdown. In addition, 14 of the most expensive funding unit alternatives were not included in the allocation because they did not satisfy the RASS objectives for WM as well as less expensive alternatives. This fact is evident in Figure 18 because the plot for perspective 2 does not extend beyond the $\$ 260$ million level. (This perspective serves as an "upper bound" for all results.)

- The results for perspectives $1 \mathrm{R}, 1 \mathrm{~S}, 3,4$, and 6 are similar, especially at about $\$ 180$ million and higher. Of these perspectives, results are shown only for perspective $1 \mathrm{R}$ because including the others would add too much clutter to the figure.

Figure 18 shows that, even though opinions about the relative importance of RASS objectives for WM differ strikingly, individuals can allocate funds in ways that perform similarly with respect to objectives.

The implications of these perspectives can also be shown from a field office point of view. Figure 19 contains four panels. Each panel represents one of the field offices and 
contains a set of plots of funding at the field office versus total WM budget, one plot per perspective. ${ }^{15}$ Thus, each perspective results in four plots - one plot for each field office.

- Most of the range for the WM budget shows good agreement about the funding to be allocated to Richland. The most noticeable exception is at about $\$ 275$ million- $\$ 300$ million; in this range, perspective $1 \mathrm{~S}$ "funds" Richland at a higher level than all others. This fact is partly traceable to funding unit 1 , which has his, h fatality estimates for the public $\mathrm{S} \& \mathrm{H}$ measure. Thus, perspective $1 \mathrm{~S}$ reduces public fatalities sooner than the other perspectives, as expected. Not apparent in Figure 19 is the fact that perspective 2 excludes six of Richland's funding unit alternatives (most of which are long-range alternatives) from the allocation. These exclusions reduce Richland's maximum funding by about $\$ 17$ million.

- Except for perspectives $1 \mathrm{C}$ and 5, the allocations are fairly similar for Rocky Flats. Perspectives $1 \mathrm{C}$ and 5 are related because the substitution rate for the compliance objective in perspective $1 \mathrm{C}$ was made equal to that for perspective 5 (i.e., $\$ 250$ million per equivalent compliancerelated facility shutdown). Thus, this level of "emphasis" on addressing compliance issues delays funding increases for Rocky Flats because other field offices have more serious compliance problems.

- There is good agreement about Chicago's funding when the EM budget is greater than about $\$ 200$ million, but less agreement when the EM budget is less than $\$ 200$ million. In addition, some of Chicago's alternatives are not included in the allocation based on perspective 2 . These exclusions reduce Chicago's maximum funding by about $\$ 10$ million.

- There is good agreement about Albuquerque's funding when the EM budget is greater than about $\$ 150$ million. Below $\$ 150$ million, funding based on perspectives $1 \mathrm{C}$ and 5 is less than funding based on the other perspectives. Like Chicago, some of Albuquerque's long-range alternatives are not included in the allocation based on perspective 2 . These exclusions reduce Albuquerque's maximum funding by about $\$ 13$ million.

Another question of interest raised in Section 5.2.4 is what happens if, for example, funds are allocated by emphasizing compliance instead of the reference substitution rates. The result, for an approximate $\$ 280$ million budget, is shown in Table 23 . The differences

${ }^{15}$ Because of the scale, only three perspectives (1R, 1C, and 1S) are labeled. However, perspective 2 clearly stands out in the Chicago and Albuquerque plots because the maximum EM budget for this perspective is slightly greater than $\$ 200$ million. 

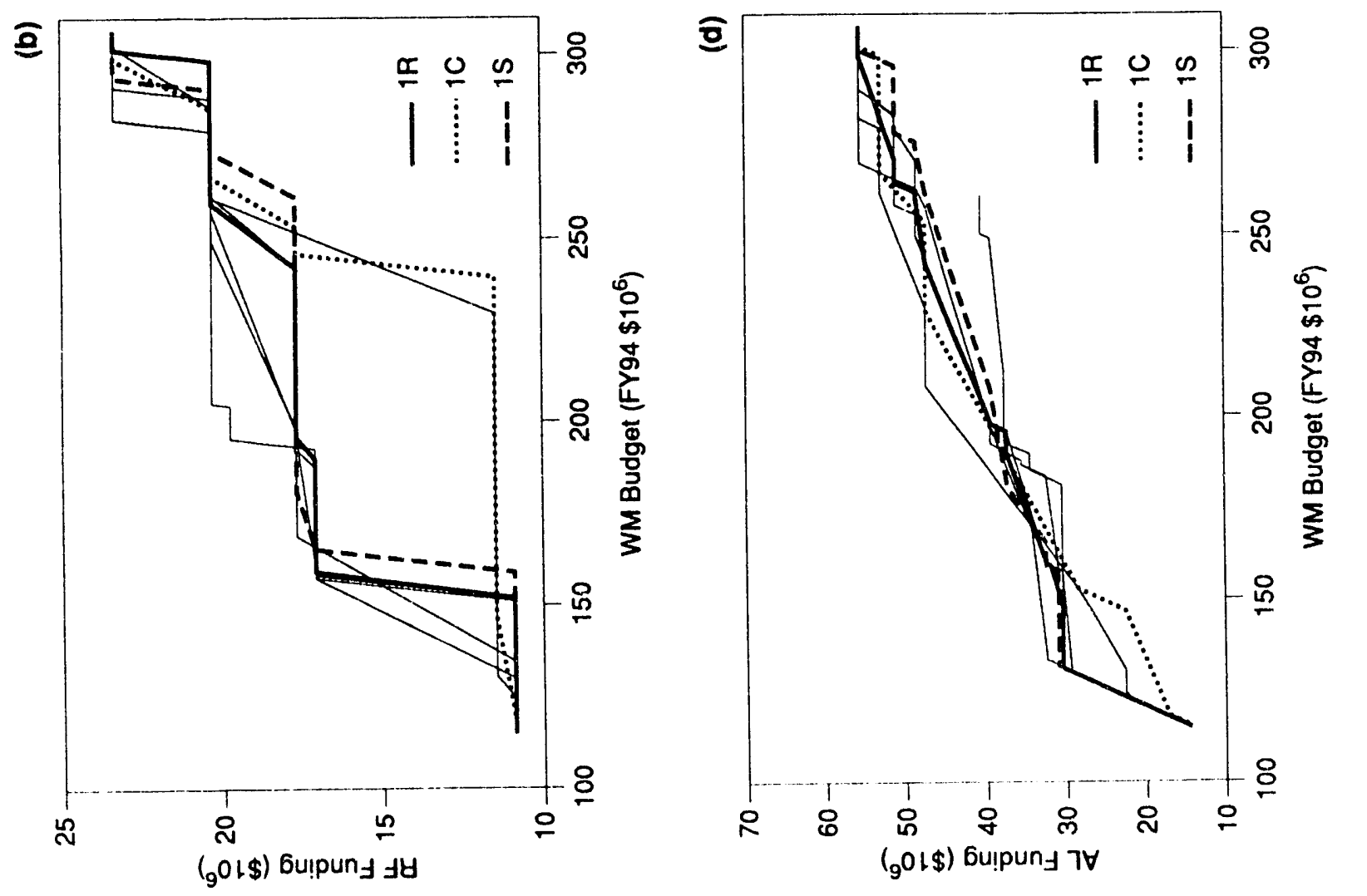


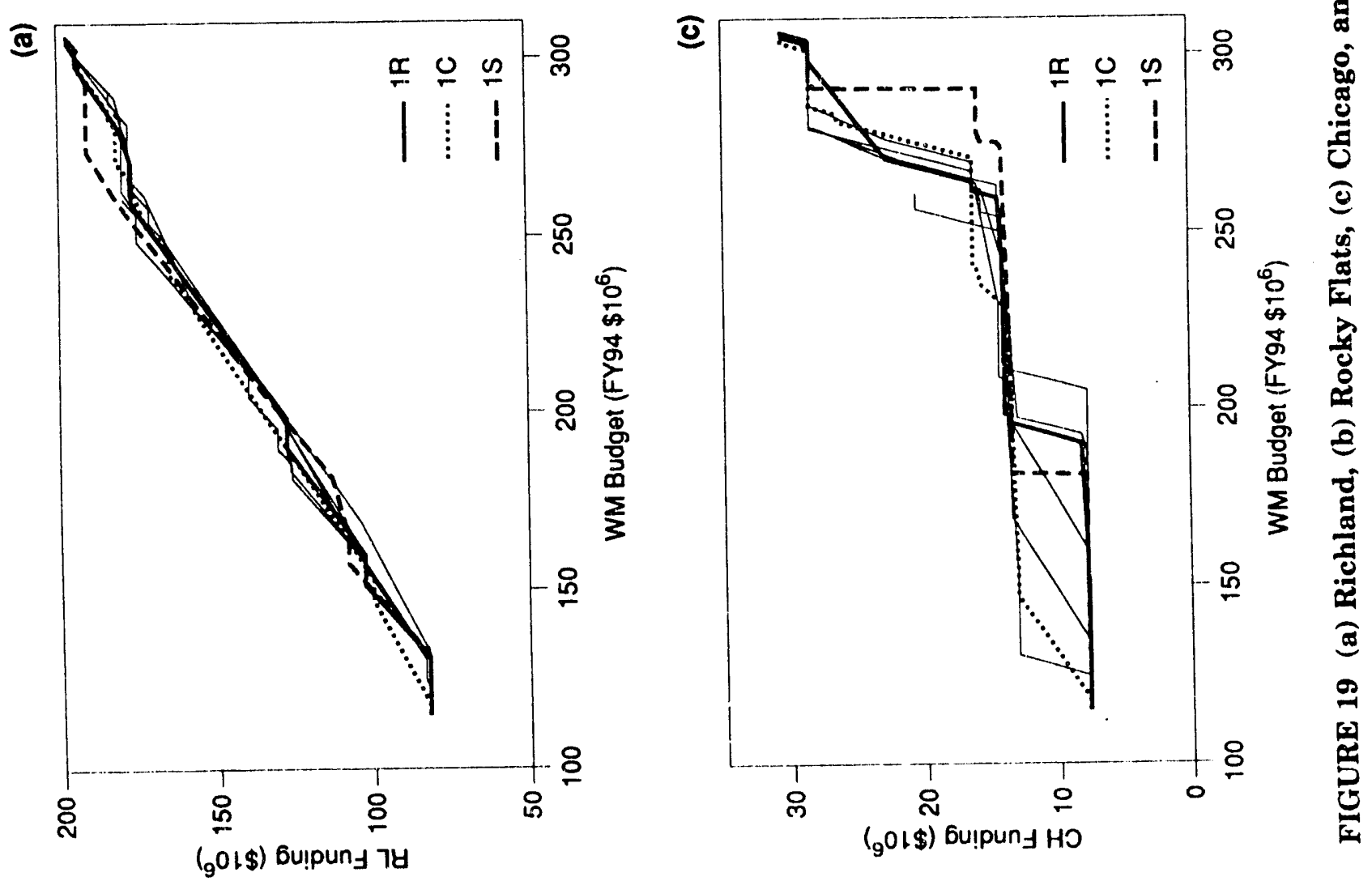
between allocations that use two different sets of substitution rates involve only four funding units and a total of $\$ 5$ million at three field offices. Two funding units receive a smaller budget and two receive a larger budget. Logically, the two funding units that receive more funds perform better with respect to compliance: a tri-party agreement at Hanford and a DOE order at Los Alamos National Laboratory are met. These gains i re "paid for" by delaying construction for funding units at Brookhaven National Laboratory and the Kansas City Plant. 


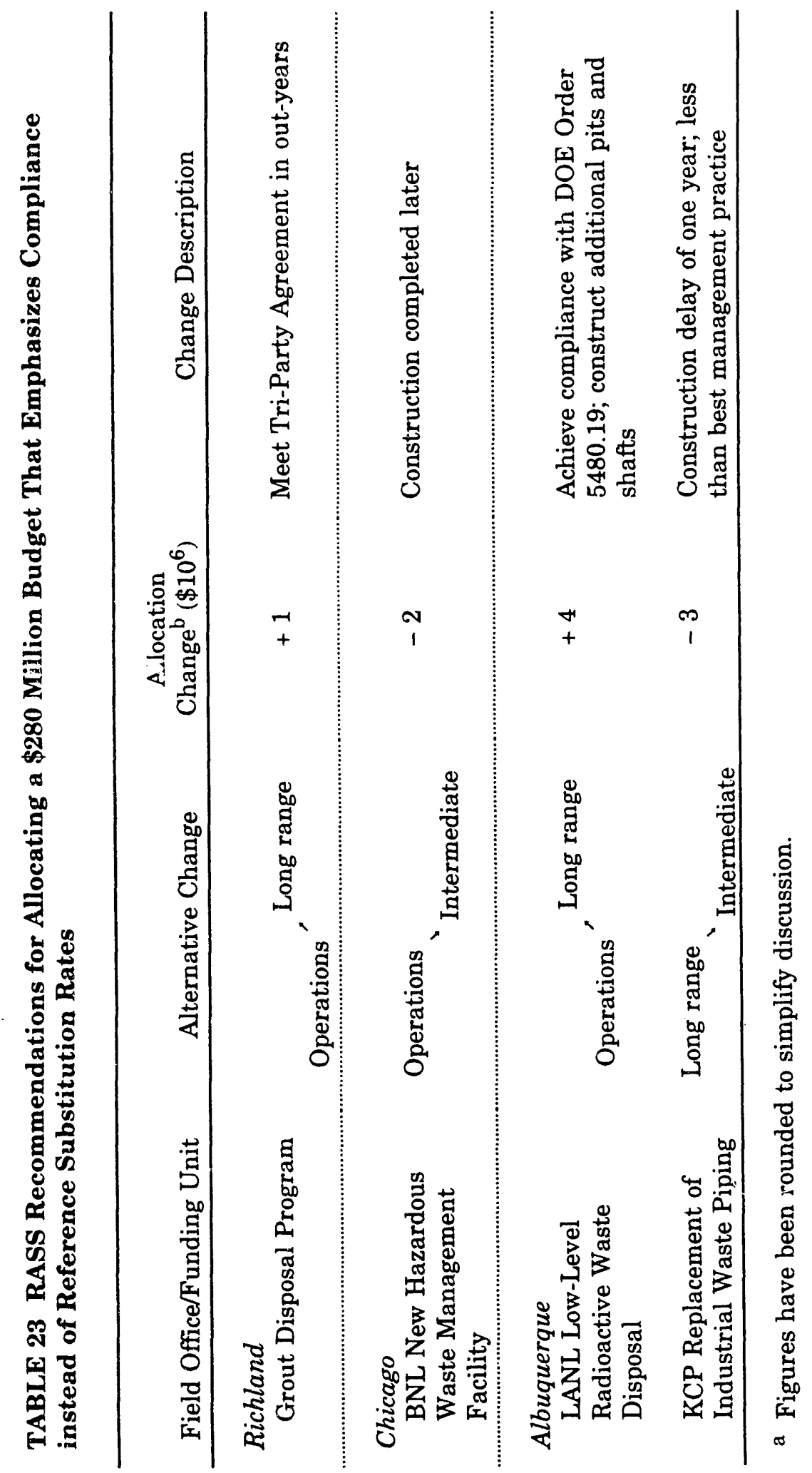




\section{ISSUES, LESSONS LEARNED, AND DIRECTIONS FOR FUTURE RASS DEVELOPMENTS}

\subsection{ISSUES AND LESSONS LEARNED}

This section presents and discusses substantive issues that surfaced during the pilot study and lessons learned from these issues. These issues and lessons learned are grouped according to subject area.

\subsubsection{Characteristics of Funding Unit Alternatives}

- Funding unit alternatives with the same target-year funding request: Several funding units analyzed during the pilot study had two or more alternatives with the same target-year funding request. In such a case, the RASS software retains the alternative with the highest utility and discards the other alternatives within the funding unit that have the same target-year request but lower utility.

Resolution: Alternatives for a single funding unit generally should not have the same funding request in the target year. RASS guidance should explicitly state the consequences of presenting alternatives with equal funding.

- Description of core funding unit alternatives: Participants in the pilot study noted that the definition of the core alternative ${ }^{16}$ could result in serious compliance problems that could lead to shutdown of production facilities. They questioned whether they should be allowed to postulate serious compliance issues and extended facility shutdowns. At the Chicago Field Office, participants were given the guidance that the core alternative should have the minimum acceptable funding. As production facility shutdowns would be unacceptable, funding for the core alternatives was assumed to be sufficient to preclude facility shutdowns. At the other field offices, participants were given guidance that funding levels could be so low that facility shutdowns could be postulated. Extended shutdowns for several funding unit alternatives were postulated.

Resolution: The objective of RASS is to assist in WM's budget decisionmaking process. To fulfill this objective, RASS should be able to indicate fully the advantages of funding an activity at one level rather than at a lower level. This ability would be hampered if alternatives with adverse consequences were precluded from analysis by RASS. However, the

\footnotetext{
16 Maintain equipment or facility in a ready-to-operate mode but do not provide operating funds.
} 
adverse consequences of a low level of funding should be assessed realistically. It is unlikely that WM and the DOE field office funding a production activity would allow that activity to be shut down for years without taking mitigative actions. Therefore, the duration of any postulated shutdown should be presumed to be weeks or months unless compelling reasons indicate a longer shutdown would result. Also, it should be assumed that keeping a facility in a ready-to-operate mode includes relatively low-cost elements (e.g., surveillance, monitoring) whose absence would trigger high-cost consequences.

\subsubsection{Safety and Health Risks}

- Consistency in estimating risks to the public from air and water pathways: One measure of meeting the $\mathrm{S} \& \mathrm{H}$ objective is estimating the risk to the public from releases of radioactive and hazardous materials. Participants in the pilot study were inconsistent in evaluating this measure. For example, some participants assumed that some risk to the public is inherent in handling radioactive and hazardous waste; others did not.

Resolution: DOE Order 5480.23, Nuclear Safety Analysis Reports, requires an evaluation of the safety bases of nuclear facilities. DOE Order 5500.3A, Planning and Preparedness for Operational Emergencies, requires development of a hazards assessment of a broad range of emergency events for radiological and nonradiological facilities for emergency planning purposes. Safety analysis reports and hazards assessments provide excellent bases for estimating risks to the public and occupational workers. They should be used, if available; however, they frequently are not available. It would be unreasonable to expect field office personnel and contractors to accurately estimate (i.e., is the risk $2.1 \times 10^{-9}$ or $3.3 \times 10^{-8}$ ) risks to the public from routine operations and accidents without such documents for purposes of RASS. Therefore, to encourage consistency, guidelines should be developed for estimating $\mathrm{S} \& \mathrm{H}$ risks from releases. These guidelines could indicate, for example, that risks to the public from releases are greater than zero when radioactive and hazardous wastes are in configurations in which barriers to releases have been damaged or removed to handle the waste.

- Risk to the public from transportation-related releases: RASS currently considers the risk to the public from trauma that results from accidents involving vehicles inat transport radioactive and hazardous wasie. RASS currently does not consider risks to the public from spillage or other releases that result from such accidents. Several external participants to the pilot study thought that to fully characterize the 
risks to the public, RASS should consider releases from transportation accidents.

Resolution: Risks to the public from releases initiated by transportation accidents will be investigated. Recently acquired information indicates that the risk of death and injury from releases initiated by transportation accidents is small (i.e., $2 \%-3 \%$ of the risk from the trauma of the collision). Unless further information indicates otherwise, the risk of death and injury per vehicle-mile on the transportation accident measure will be increased by $2 \%-3 \%$ to account for releases.

- Risks to occupational workers from releases of hazardous material: RASS currently has a measure to account for S\&H risks to occupational workers from exposure to radioactive workers, in addition to the risks of death and iı, dry from general operations. However, it does not curr'ntly have an additional scale for risks of exposure to hazardous materials. Several participants thrught that RASS should consider occupational risks from exposure $t$ ' hazardous waste in the same way as they consider occupational risks from radiation.

Resolution: Statistics on working with hazardous materials will be examined. The results of this examination will help determine how to address this issue in RASS.

- Need for the S\&H program measure: RASS currently includes this measure to give credit for programs to enhance the safety and health of the public and workers beyond that required for compliance. Because of the pervasiveness of compliance requirements, less than $10 \%$ of the funding units considered in the pilot study had entries for this measure. Also, one participant noted that contractors who completed the RASS data forms spent inordinate time deciding whether an expenditure is required for compliance. On the other hand, the $\mathrm{S} \& H$ program measure captures information that would be lost if it were deleted.

Resolution: This measure should be retained. It is important under DOE policy to protect the safety and health of the public and workers, and it is appropriate to give credit to programs that do so.

- Input of direct collective exposure of radiation workers: To estimate collective radiation exposure, RASS currently uses average exposure rates compiled by the U.S. Nuclear Regulatory Commission for radiation workers at commercial nuclear power plants together with worker-hours of radiation exposure (RASS input). For a few funding units analyzed in which radiation workers work in more intensive than average radiation fields, input of actual hours of exposure would underestimate collective exposure. For these funding units, direct estimates of 
collective radiation exposure were available. Either hours of exposure could be adjusted to yield the correct collective exposure or RASS could be modified to accept input of collective exposure.

Resolution: RASS input will be changed to accept collective radiation exposure as an alternative input to radiation worker-hours of exposure.

\subsubsection{Meeting Waste Management Needs}

- Activities without conventional waste throughput or construction: Several funding units analyzed in the pilot study did not have conventional waste throughput or construction. Except possibly for meeting milestones, these funding units did not have value toward meeting the waste-managed objective. Such activities generally include environmental monitoring and infrastructure and support projects. Some participants thought that these activities are at an unfair disadvantage in the RASS rating system and that they should have value on a constructive waste-managed measure.

Resolution: Participarts at the FO/HQ Working Group meeting on November 9-10, 1992, considered this issue. They concluded that it is necessary to determine whether a problem exists. A composite matrix of overall funding level and funding unit alternatives at each level was presented at the meeting. Participants were asked to consider whether the matrix indicated that funding units without conventional wastemanaged value fared more poorly than would be expected in view of their relative importance. In general, the results were thought to be reasonable. However, ways to incorporate value for these activities will be investigated.

- Duration of slippage in meeting construction schedules: One of the measures for the waste-managed objective for construction activities is the relationship between construction schedule and construction status (new capacity status). The rating on the scale used in the pilot study depended on whether there was no slippage, a slippage of 1-6 months, 7-12 months, or greater than 12 months. Participants at the Rocky Flats pilot study noted that the construction process is only one factor that affects construction status. Other important factors include obtaining permits from EPA and state agencies, which involves more uncertainty thar construction. In practice, delays of 1-6 months are considered trivial, while delays of 1-3 years are not uncommon. These participants thought that the schedule scale was unrealistic.

Resolution: Intervals in the constructed scale for construction delays will be modified to be more realistic. 
- Value for research and development $(R \& D)$ projects: An alternative for one funding unit analyzed in the pilot study included an R\&D project. The utility of this alternative was less than another alternative with a lower funding request because no value was assigned to the R\&D project. $\mathrm{R} \& \mathrm{D}$ is essential for improving waste management techniques. However, whether a specific R\&D project would have benefits is speculative, and benefits, if any, are usually longer range thas those on the RASS horizon.

Resolution: RASS should be capable of assigning value to R\&D projects. A measure, similar to the S\&H programs measure, should be added to RASS. The input for this measure should be the dollars requested for the $R \& D$ project.

- Definition of milestones: One of the measures of meeting waste management requirements is meeting milestone schedules. During the pilot study, it was discovered that some milestones are specific to certain field offices, while others are defined at DOE Headquarters.

Resolution: To promote uniformity, milestones to be measured will be only Headquarters-tracked, Five-Year Plan milestones.

\subsubsection{Specifying Funding Units}

- Relationship between funding units and WM budgeting units: To test the versatility of RASS, funding units analyzed in the pilot study were designed to confront RASS with diverse situations. In doing so, participants realized that it is important that the funding units used by RASS be readily related to the units used in five-year plans and the WM budget decision-m...king process (e.g., the ADS and the task description document). In this way, the effort required by DOE field office personnel and contractors to develop funding units would be reduced, and RASS would be more easily integrated with the budget decisionmaking process. Participants were uncertain whether firm rules should be developed and, if so, what the rules should be.

Resolution: Participants at the FO/HQ Working Group meeting on November $9-10,1992$, concluded that it would be inappropriate to require that the scope of a RASS funding unit correspond precisely to the scope of a WM budgeting unit. Field office personnel and contractors should have flexibility to define RASS funding units in ways that make the most sense. However, it was also concluded that it is important to be able to relate RASS funding units to WM budgeting units readily and unambiguously. Therefore, a written cross-reference should be developed between a RASS funding unit (and its activities) 
and related WM budgeting units, when they do not correspond on a oneto-one basis.

- Interdependencies among funding units: Ideally, funding units shou'd be independent of each other; that is, the viability of an alternative of one funding unit should not depend on which alternative of another funding unit is funded. However, it is not always possible to define funding units that are completely independent. When few combinations of funding levels are untenable (e.g., the core alternatives of two funding units that each have four alternatives -1 of 16 combinations), the untenable combination can readily be eliminated from consideration by RASS. However, when the number of untenable combinations is large, RASS cannot treat the situation unless the interdependent funding units are combined into one funding unit.

Resolution: Guidance will be developed to define when interdependencies among funding units can be treated by RASS and when interdependent funding units should be combined.

\subsubsection{Waste Types and Values}

- Industrial wastewater and its treatment: RASS currently assigns waste management credit for treatment, storage, transport, and disposal of six types of waste (HLW, LLW, TRU, hazardous, mixed hazardous and radioactive waste, and sanitary). No waste management value is assigned to wastes classified as "other." Several funding units analyzed during the pilot study involved industrial wastewater.

Resolution: Industrial wastewater is treated at most (if not all) DOE sites. The RASS suftware will be modified to consider it as a distinct waste type for which waste-managed value will be assigned.

- Greater differentiation among TRU wastes: RASS currently assigns one value for management of mixed waste. No distinction is made between hazardous waste mixed with LLW and hazardous waste mixed with TRU waste. One participant noted that the cost of managing mixed waste depends on whether the radioactive component is LLW or TRU. Also, the cost of managing TRU waste depends on how highly radioactive it is, that is, whether it must be handled remotely ("remote handled") or not ("contact handled").

Resolution: The feasibility of differentiating (1) the waste-managed value between hazardous waste mixed with LLW and hazardous waste mixed with TRU waste and (2) the waste-managed value between remote-handled TRU waste and contact-handled TRU waste will be studied. 


\subsubsection{Constructed Scale for Compliance}

- Nuclear safety requirements: In December 1991, DOE published proposed rules in the Federal Register that would codify a number of substantive nuclear safety requirements currently contained in DOE orders and that would establish procedural rules to be used in proceedings in which violation of the nuclear safety requirements would be considered. The proposed rules would implement provisions of the Price-Anderson Amendment Act. The version of the constructed scale for compliance used at some pilot sites treated violations of nuclear safety requirements as analogous to violations of statutory requirements rather than as only violations of DOE orders. Nevertheless, some participants considered violation of nuclear safety requirements as only violation of $\mathrm{DOE}$ orders.

Resolution: Because final rules have not been issued, nuclear safety requirements have not been codified and are only required by DOE order. To be in better conformity with the current status of the law, the compliance scale should treat violations of nuclear safety requirements as violations of provisions of DOE orders that are mandatory under DOE policy.

- Driver, mixed, or outcome-dependent compliance scale: The compliance scales used in the pilot study had mixed levels. Some levels were defined in terms of violations of drivers (i.e., Tiger Team milestones, DOE orders, environmental regulations). Other levels were defined in terms of drivers and outcomes (i.e., fines, facility shutdowns). Some external participants suggested that it would be more consistent to use a single, outcome-dependent perspective.

Resolution: It was decided to reject the suggestion of an outc - medependent compliance scale. Because some outcomes (i.e., fines, facility shutdowns) are represented on other measures, an outcome-dependent scale would be less independent than the current mixed compliance scale. Also, DOE has a strong policy of compliance with environmental regulations and $S \& H$ requirements of statutes, regulations, and orders. The purpose of the compliance scale is to measure the seriousness of a deviation from DOE's policy promoting compliance. Seriousness is not necessarily measured solely by outcome. A facility shutdown ordered by a federal court is likely to be more serious to DOE than one ordered internally by DOE. Changing the compliance scale to be more consistent with OMB drivers used in developing an ADS will be studied. 


\subsection{FUTURE RASS DEVELOPMENTS}

The pilot study results summarized in this report are being reviewed by the three groups described in Section 1.1: DOE FO/HQ Working Group, Technical Review Group, and external parties. Following review of the pilot study results by these three groups, an enhanced RASS design will be prepared for the proposed FY 1995 full-scale test to be conducted in spring/summer 1993. A decision on the scope and timing of the full-scale test will be made by EM-33 following the review of the pilot study. The following objectives reflect preliminary thinking based on the pilot study experience.

The primary objectives for the proposed full-scale test are:

- Evaluate the usefulness of RASS allocation insights, and

- Evaluate the usefulness of RASS at the field office and site level.

Several procedural objectives have also been identified:

- Include all EM-30 activities (all funding units);

- Include additional scales in RASS (e.g., long-term land use, risk to future generations);

- Involve the public in a meaningful way (Section 4.4.2);

- Include specific funding unit dependencies in the RASS allocation;

- Use "realistic" funding unit alternatives (avoid totally unacceptable alternatives that, for example, result in facility or site shutdowns for long periods - but include more alternatives than the typical target and planning cases);

- Integrate RASS with other EM-30 planning activities; and

- Prepare a user-friendly software interface to RASS so funding unit scorers can enter RASS scores directly.

Spring/summer 1993 appears to be the best near-term opportunity for conducting the full-scale test because that period would involve less conflict with ongoing EM-30 planning and budgeting activities. Training for field offices and contractors would be needed in late spring.

On the basis of pilot study experience, additional guidance is needed on several topics:

- Funding units (definition of and how to construct from WM activities),

- Funding unit alternatives (definitions of budget cases to be included), 
- Scoring instructions to develop more consistency (e.g., very low level exposures to radiation),

- Additional RASS objectives and scales (e.g., risk to future generations),

- How to include uncertainty in scoring,

- How to explicitly indicate funding unit dependencies, and

- Use of RASS software to enter scores for funding unit alternatives.

Training requirements probably should include an introductory session for field office and contractor leaders (one location). Training at each field office for participants would include more detailed scoring guidance. The need for additional technical support from ANL should be expected. 


\section{REFERENCES}

Absil, M.J.G., P.H. Kier, M.J. Jusko, P.F. Sapinski, W.A. Buehring, R.G. Whitfield, and T.D. Wolsko, 1992, Argonne National Laboratory, Argonne, Ill., unpublished information on the Rocky Flats Office pilot study, Oct.

Buehring, W.A., R.G. Whitfield, and T.D. Wolsko, 1992, Argonne National Laboratory, Argonne, Ill., unpublished information on the draft design concept, Jan.

Holt, M., R. Meltz, and M. Simpson, 1991, Setting Priorities for Department of Energy Environmental Activities, Congressional Research Service, Library of Congress, 91-150 ENR, p. 31, Feb. 6.

Keeney, R.L., 1982, Decision Analysis: An Overview, Operations Research, 30:803-838.

Keeney, R.L., 1992, Value-Focused Thinking: A Path to Creative Decisions, Harvard Press, Cambridge, Mass.

Keeney, R.L., and H. Raiffa, 1976, Decisions with Multiple Objectives, Wiley, New York, N.Y.

Kier, P.H., M.J.G. Absil, M.J. Jusko, P.F. Sapinski, W.A. Buehring, R.G. Whitfield, and T.D. Wolsko, 1992a, Argonne National Laboratory, Argonne, Ill., unpublished information on the Richland Field Office pilot study, Oct.

Kier, P.H., M.J.G. Absil, M.J. Jusko, P.F. Sapinski, W.A. Buehring, R.G. Whitfield, and T.D. Wolsko, 1992b, Argonne National Laboratory, Argonne, Ill., unpublished information on the Chicago Field Office pilot study, Oct.

Kier, P.H., M.J.G. Absil, M.J. Jusko, P.F. Sapinski, W.A. Buehring, R.G. Whitfield, and T.D. Wolsko, 1992c, Argonne National Laboratory, Argonne, Ill., unpublished information on the Albuquerque Field Office pilot study, Oct.

Office of Technology Assessment, 1991, Complex Cleanup: The Environmental Legacy of Nuclear Weapons Production, U.S. Government Printing Office, Washington, D.C., Feb.

U.S. Department of Energy, 1991, Environmental Restoration and Waste Management: FiveYear Plan - Fiscal Years 1993-1997, DOE/S-0089P, Washington, D.C., Aug.

von Winterfeldt, D., and W. Edwards, 1986, Decision Analysis and Behavioral Research, Cambridge University Press, Cambridge, England.

Whitfield, R.G., W.A. Buehring, and T.D. Wolsko, 1992, Argonne National Laboratory, Argonne, Ill., unpublished information on objectives, scales, and scoring the RASS pilot study, June. 
APPENDIX A

DATA FOIRM AND SPECIFIC INSTRUCTIONS FOR COMPLETING

THE DATA FORM FOR THE RASS PILOT STUDY 


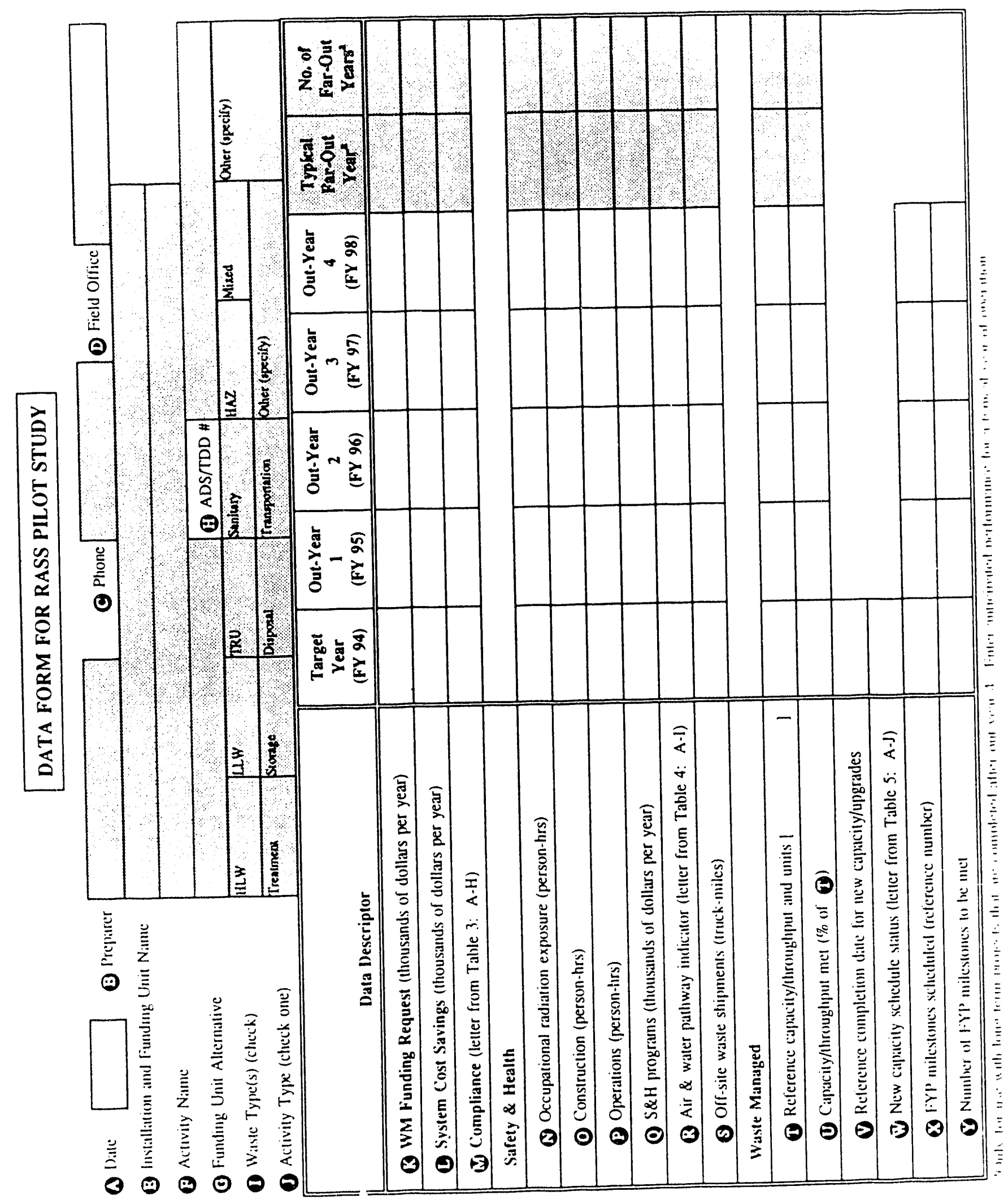




\begin{tabular}{|c|c|}
\hline $\begin{array}{c}\text { Field } \\
\text { or Row } \\
\end{array}$ & Instructions \\
\hline (A) & Enter date of completion of form. \\
\hline B & Enter name of preparer. \\
\hline $\boldsymbol{C}$ & Enter phone number of preparer. \\
\hline D & Enter Field Office name. \\
\hline (B) & Enter installation and funding unit name. \\
\hline $\boldsymbol{B}$ & Enter activity title. \\
\hline $\boldsymbol{\Theta}$ & Identify funding unit alternative (core, operations, intermediate, long range, ...). \\
\hline $\mathbb{9}$ & Enter ADS or TDD number(s) that are relevant for this funding unit and activity. \\
\hline (1) & $\begin{array}{l}\text { Identify one or more waste types (HLW, LLW, TRU, sanitary, HAZ, mixed, or } \\
\text { other) involved in this activity by checking the appropriate box(es). If none is } \\
\text { involved, check "Other" and specify "None." If multiple waste types are } \\
\text { involved but one waste type dominates the activity, please circle the check mark } \\
\text { for that waste type. This dominant waste type should be the basis for the } \\
\text { estimate of capacity/throughput in Row ( })\end{array}$ \\
\hline (3) & $\begin{array}{l}\text { If this activity involves the treatment, storage, disposal, or transportation of } \\
\text { waste, identify which one by checking the appropriate box. If this activily does } \\
\text { not involve equipment, check "Other" and identify the type of activity (e.g., } \\
\text { environmental monitoring, grouting, maintenance). If more than one operation is } \\
\text { involved (e.g., treatment and storage), an additional data form will be needed to } \\
\text { list the capacity/throughput of the operation not covered on the first form. }\end{array}$ \\
\hline & $\begin{array}{l}\text { Rows } \mathbb{B} \text { and } \boldsymbol{C} \text { involve two aspects of costs. Row } \mathbb{B} \text { involves funding } \\
\text { requests and row } \boldsymbol{D} \text { involves "cost savings" that may result for other funding } \\
\text { units if requested funds are received. }\end{array}$ \\
\hline $\mathbb{B}$ & $\begin{array}{l}\text { Enter the amount of funds requested (current-year dollars) in the target year (T) } \\
\text { and anticipated in each of the out-years, as appropriate. Use the escalation rates } \\
\text { provided in DOE/HQ guidance. Typical far-out year costs should be expressed } \\
\text { in current dollars for out-year } 4 \text {. If it is known that funding is needed beyond } \\
\text { year } T+4 \text {, enter a cost estimate that is "typical" (e.g., the average cost) in the } \\
\text { next-to-last column, and the number of years for which this cost estimate } \\
\text { applies. Instead of a "typical" number, cost estimates for each year are } \\
\text { acceptable and should be attached to the data form. If the activity is io be } \\
\text { funded for one (the target) and only one year, entries for the out-years ar: not } \\
\text { needed. }\end{array}$ \\
\hline
\end{tabular}




\begin{tabular}{|c|c|}
\hline $\begin{array}{l}\text { Field } \\
\text { or Row }\end{array}$ & Instructions \\
\hline & $\begin{array}{l}\text { While the form has space for entries for years after the target year, in some } \\
\text { instances these will only have to be determined once -- for the "operations" } \\
\text { funding unit alternative. If appropriate, RASS will assume the operations } \\
\text { level of funding (and therefore the same scores for the other fields) for the } \\
\text { out-years for all other funding scenarios. In this case, different funding } \\
\text { scenarios will mainly affect what can be done and what will happen in the } \\
\text { target year. When appropriate, scores for rows } \mathbf{D} \text { - (as for row } \mathbf{O} \text { ) for } \\
\text { years beyond year } \mathrm{T}+4 \text { may be enumerated or specified in terms of a } \\
\text { "typical" estimate and the number of years for which the "typical" estimate } \\
\text { is appropriate. }\end{array}$ \\
\hline D & $\begin{array}{l}\text { If this activity reduces costs for other funding units, those cost savings (current- } \\
\text { year dollars) may be "claimed" here. Name the funding units that are affected } \\
\text { in an attachment. If fines from regulatory agencies are likely for this alternative, } \\
\text { list the fine as a negative cost savings. }\end{array}$ \\
\hline 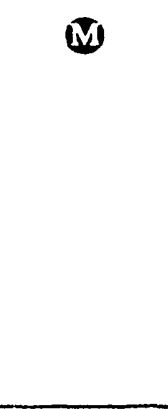 & $\begin{array}{l}\text { Enter a letter (A-H), where the meaning of the letter is described in Table } 3 \text {. } \\
\text { Each letter denotes a "state" of compliance that may result at the funding level } \\
\text { specified for a particular year (row } \mathbb{B} \text { ). If more than one breach/violation exists, } \\
\text { then list the number of breaches/violations followed by a "p" and the appropriate } \\
\text { letter (B-H) from Table } 3 \text {. Thus, if two different Level C breaches and one } \\
\text { Level G dispute exist for a particular year, the entry would be } 2 / \mathrm{C}, 1 / \mathrm{G} \text {. If the } \\
\text { compliance level is uncertain, use probabilities to indicate likely outcomes (i.e., } \\
\text { a } 75 \% \text { chance of Level A and a } 25 \% \text { chance of Level E). }\end{array}$ \\
\hline & $\begin{array}{l}\text { Rows } \mathbb{Q} \text { - involve safety and health. Rows } \mathbf{Q} \text { involve occupational } \\
\text { health and safety and rows } \mathbb{Q} \text { and } \mathbf{\Theta} \text { involve public health and safety. } \\
\text { Workers involved in activities that involve more than one category should } \\
\text { be included in as many calculations as are appropriate. (For example, a } \\
\text { worker involved in routine operations that result in radiation exposures } \\
\text { would be included in rows } \mathbb{Q} \text { and } \mathbf{P} \text {.) }\end{array}$ \\
\hline $\mathbb{8}$ & $\begin{array}{l}\text { Enter the number of person-hrs of radiation exposure for workers. Include } \\
\text { radiation exposures during construction (both new construction and upgrades) } \\
\text { and routine operations. Do not include support and administrative personnel. } \\
\text { [RASS will use standard exposure levels and conversion factors to arrive at } \\
\text { morbidity and mortality estimates.] }\end{array}$ \\
\hline $\boldsymbol{0}$ & $\begin{array}{l}\text { Enter the number of worker-hours to be expended on construction projects. } \\
\text { [RASS will apply an appropriate accident rate to arrive at morbidity and } \\
\text { mortality estimates.] }\end{array}$ \\
\hline $\boldsymbol{P}$ & $\begin{array}{l}\text { Enter the number of worker-hours for operations activities. [RASS will apply } \\
\text { standard accident rates to arrive at morbidity and mortality estimates.] }\end{array}$ \\
\hline
\end{tabular}




\begin{tabular}{|c|c|}
\hline $\begin{array}{l}\text { Field } \\
\text { or Row }\end{array}$ & Instructions \\
\hline Q & $\begin{array}{l}\text { Enter the dollar amount (in thousands of current-year dollars; a portion of } \\
\text { row } \boldsymbol{Q} \text { ) to be used for programs that are intended to reduce safety and health } \\
\text { risks. These could be training programs, awareness programs, protection } \\
\text { equipment or devices, etc. [The intent here is to recognize efforts beyond that } \\
\text { required by other fields, such as compliance, to reduce safety and health risks.] }\end{array}$ \\
\hline $\mathbb{B}$ & $\begin{array}{l}\text { Enter the letter }(A-I) \text { from Table } 4 \text { that indicates the plausible extent of impacts } \\
\text { on the public due to air or water exposure pathways. The letters correspond to } \\
\text { scenarios that account for severity of effect (sickness or death) and the expected } \\
\text { number of people affected. It is anticipated that Level A will be appropriate in } \\
\text { most situations. }\end{array}$ \\
\hline $\boldsymbol{S}$ & $\begin{array}{l}\text { Enter the number of truck-miles associated with transportation of waste. [RASS } \\
\text { will apply appropriate accident rates to arrive at morbidity and mortality } \\
\text { estimates.] }\end{array}$ \\
\hline & 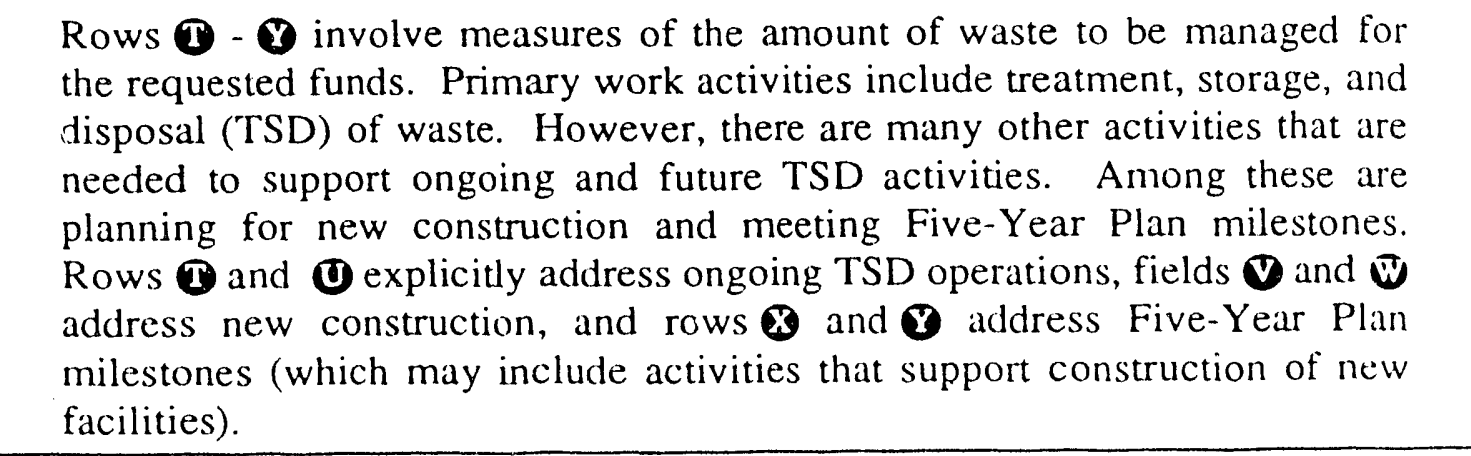 \\
\hline (T) & $\begin{array}{l}\text { If this activity directly involves the treatment, storage, or disposal of waste, what } \\
\text { is the reference capacity/throughput (i.e., the largest amount among the funding } \\
\text { unit alternatives - in most cases, the long-range level)? What is the unit of } \\
\text { measure of that capacity/throughput? Enter the unit of measure within the } \\
\text { square brackets. (For example, for a storage tank, the unit of measure may be } \\
\text { [millions of gallons]; for a processing plant, the unit of measure may be } \\
\text { [millions of } \mathrm{ft}^{3} / \mathrm{yr} \text { ].) If this activity does not directly involve the treatment, } \\
\text { storage, or disposal of waste, enter "NA" (not applicable). If no } \\
\text { capacity/throughput is planned for a particular year, enter zero. Shortfalls in } \\
\text { capacity/throughput will be noted in row } \mathbf{O} \text {. If more than one operation (e.g., } \\
\text { treatment and storage) is involved, use a second data form to show capacity or } \\
\text { throughput for the second operation. }\end{array}$ \\
\hline (1) & $\begin{array}{l}\text { Enter the percentage (or amount) of the capacity/throughput noted in row that } \\
\text { can be met at the specified level of funding. Shortfalls (i.e., percentages less } \\
\text { than } 100 \% \text { ) indicate potential impediments for other operations (i.e., other } \\
\text { funding units). If the entry in row is "NA" or " } 0 \text {," enter } 100 \% \text {. }\end{array}$ \\
\hline
\end{tabular}




\begin{tabular}{|c|c|}
\hline $\begin{array}{l}\text { Field } \\
\text { or Row }\end{array}$ & Instructions \\
\hline$\nabla$ & $\begin{array}{l}\text { Enter the reference completion date for new capacity/throughput. This date is } \\
\text { the earliest completion date possible among the proposed funding t.nit } \\
\text { alternatives. As for row } \mathbb{D} \text {, it is expected that this will correspond to the iong- } \\
\text { range funding unit alternative in most cases. If there is no construction activity, } \\
\text { enter "NA." }\end{array}$ \\
\hline $\bar{\Psi}$ & $\begin{array}{l}\text { Enter the letter (A-J) from Table } 5 \text { that best describes the schedule status for } \\
\text { construction activities. The letters correspond to scenarios that account for } \\
\text { length of delay ( } 1-6 \text { months, } 7-12 \text { months, }>12 \text { months) and the year completion } \\
\text { is scheduled (target year, out-year } 1 \text {, or after out-year 1). It is anticipated that } \\
\text { Level A (no delay) will be appropriate in most situations. Entries of H or higher } \\
\text { will require further explanation (please attach explanation to data form). If there } \\
\text { is no construction activity, enter "NA." }\end{array}$ \\
\hline $\boldsymbol{x}$ & $\begin{array}{l}\text { Enter the reference number of Five-Year Plan milestones scheduled for each } \\
\text { year. The FY 1994-1998 FYP is the basis for the reference number. }\end{array}$ \\
\hline ( & $\begin{array}{l}\text { Enter the number of scheduled Five-Year Plan milestones that can be met at the } \\
\text { specified funding level. }\end{array}$ \\
\hline
\end{tabular}


APPENDIX $B$

BACKGROUND INFORMATION ON FUNDING UNIT ALTERNATIVES USED IN THE RASS PILOT STUDY 


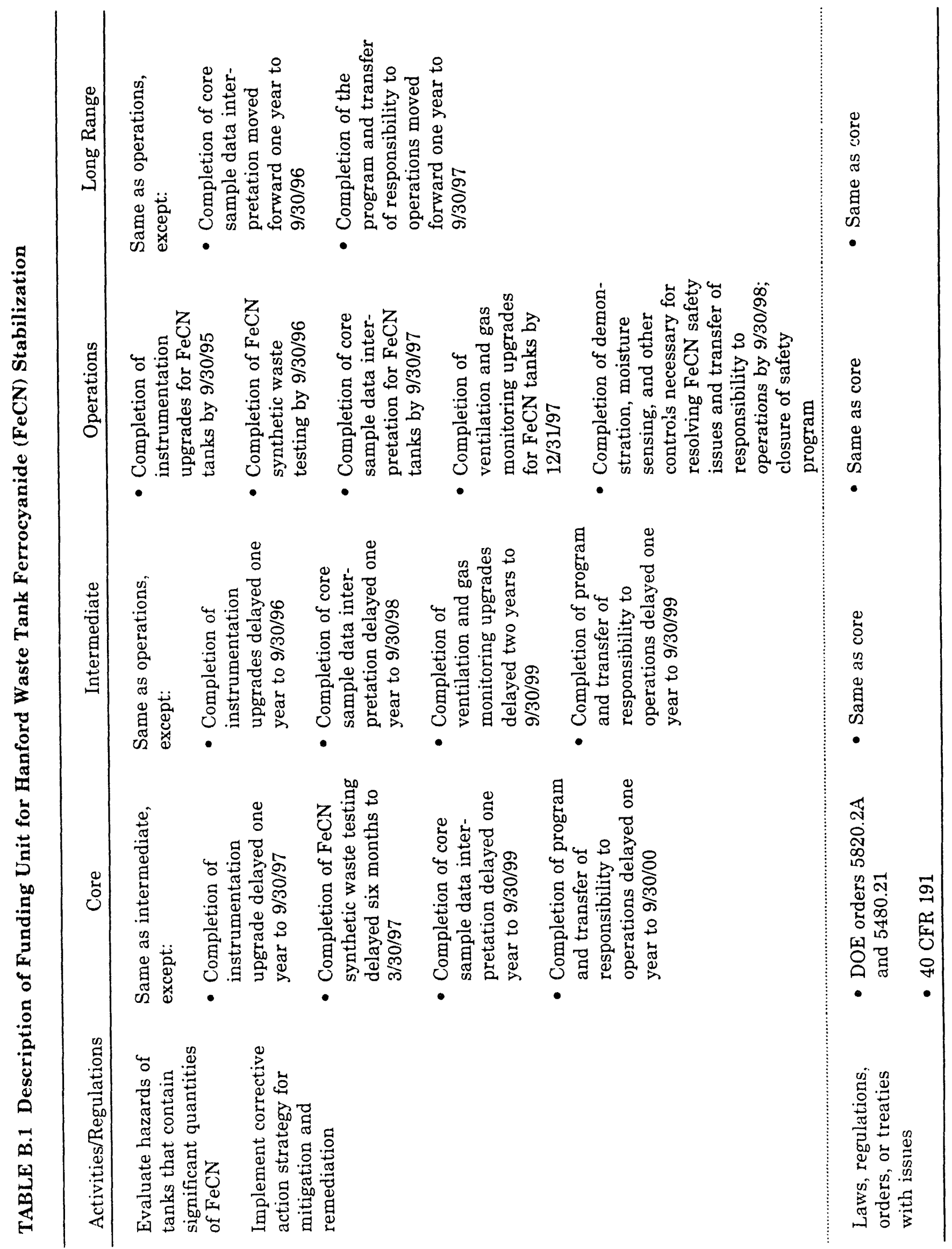




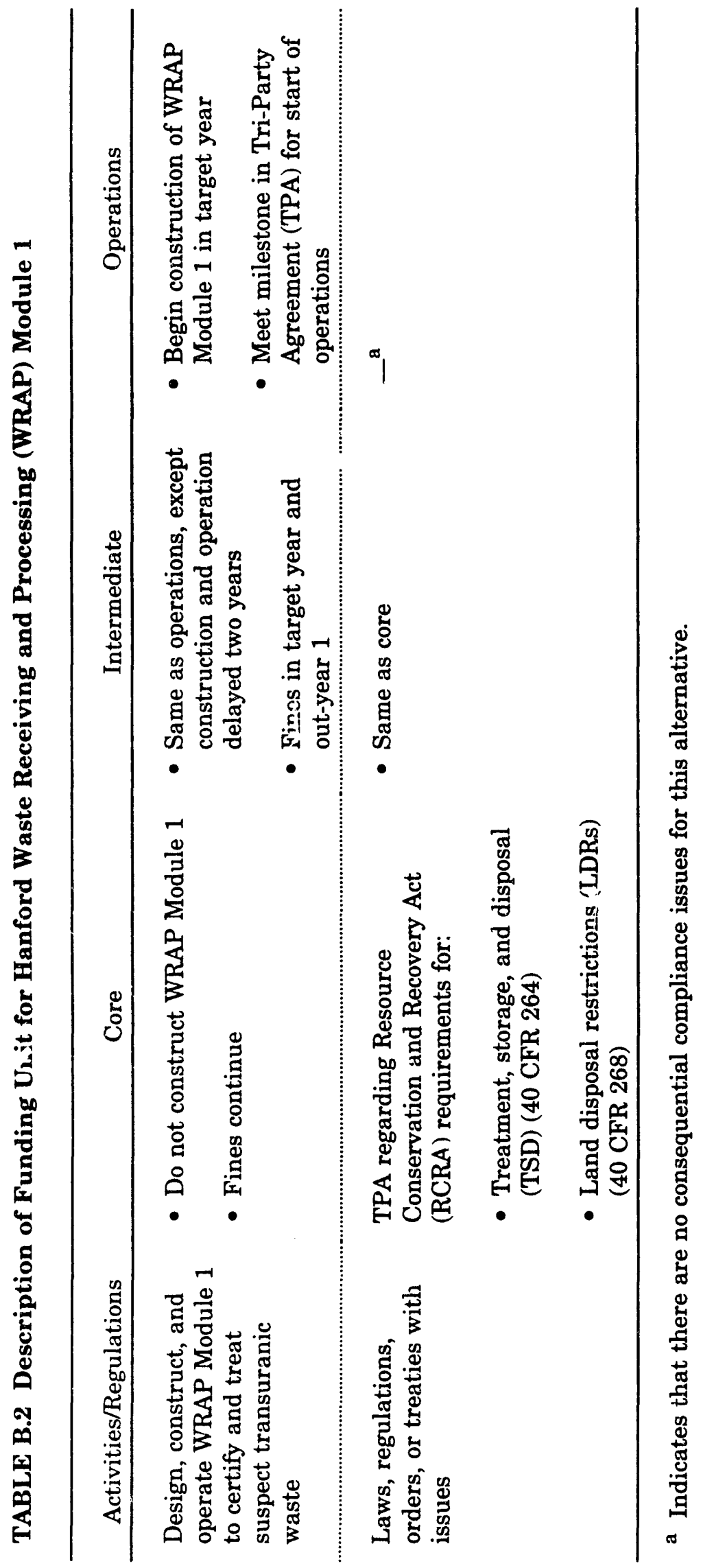




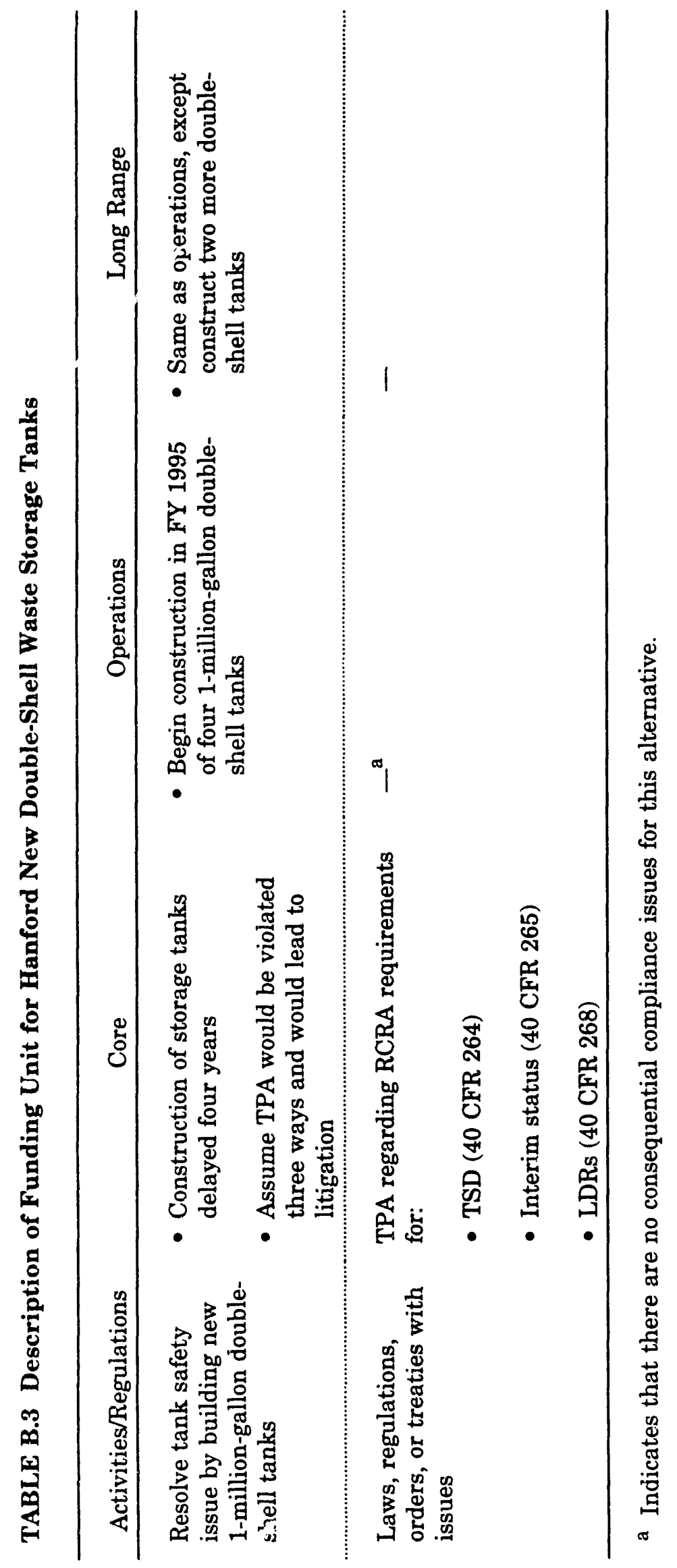



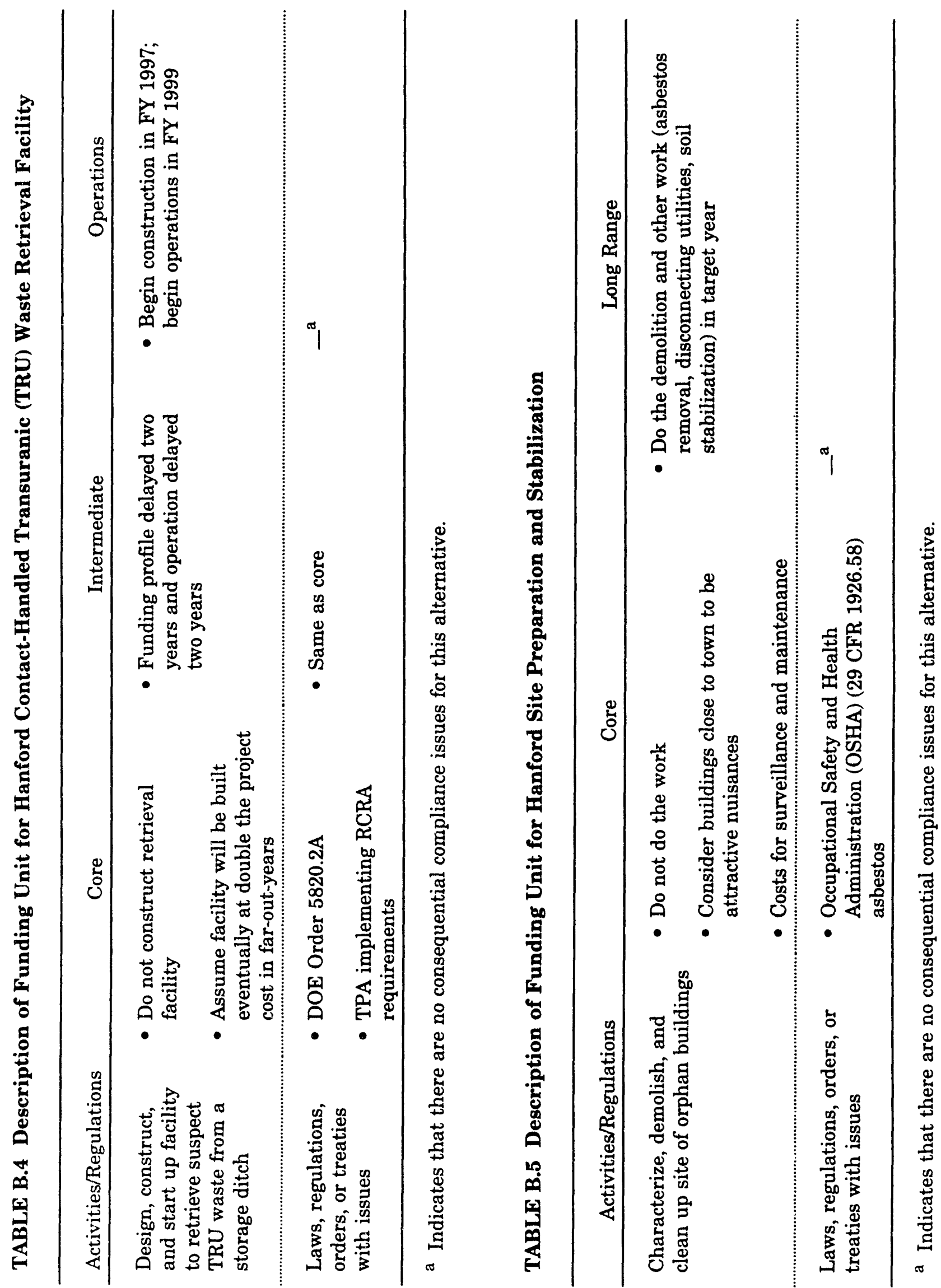


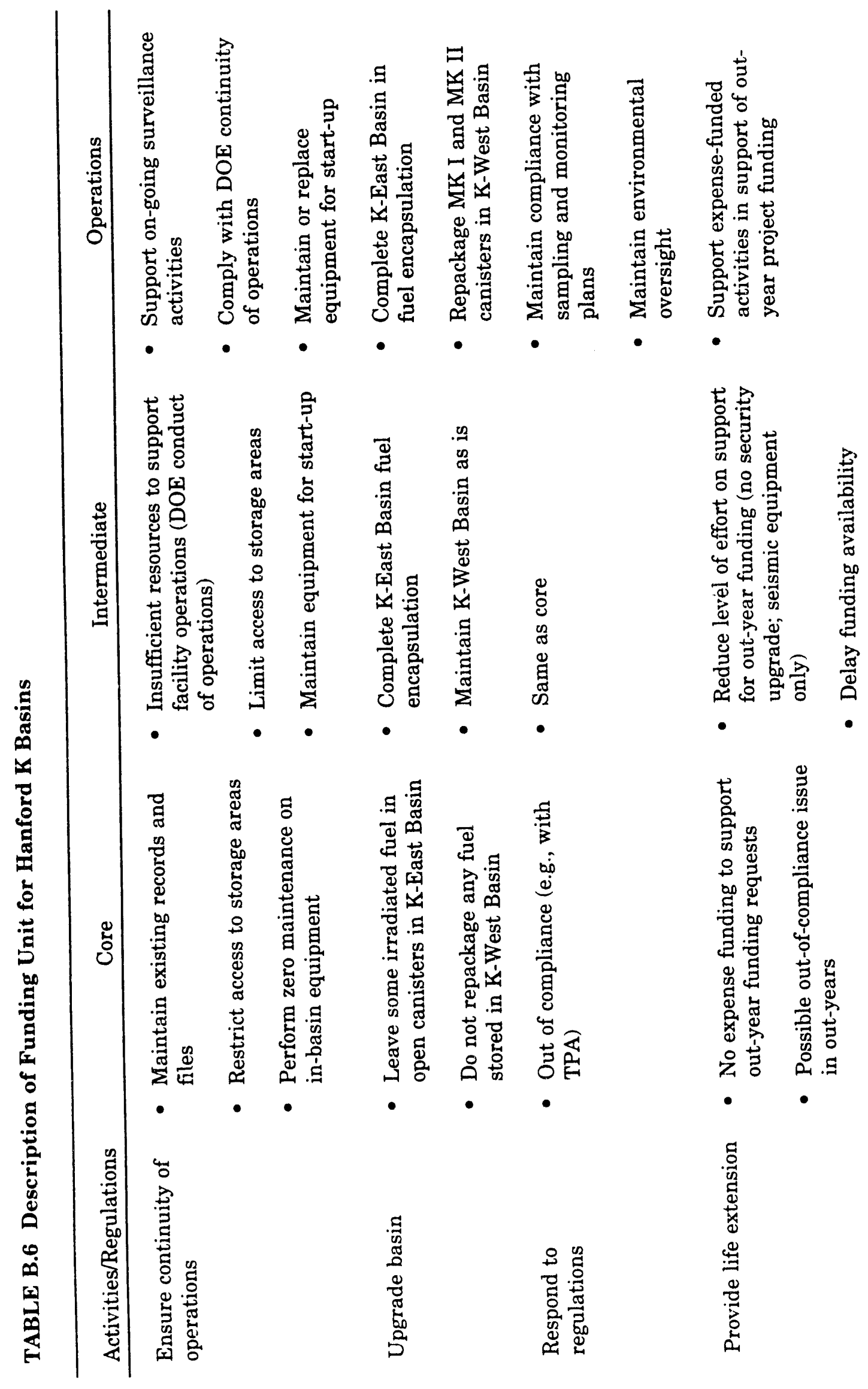



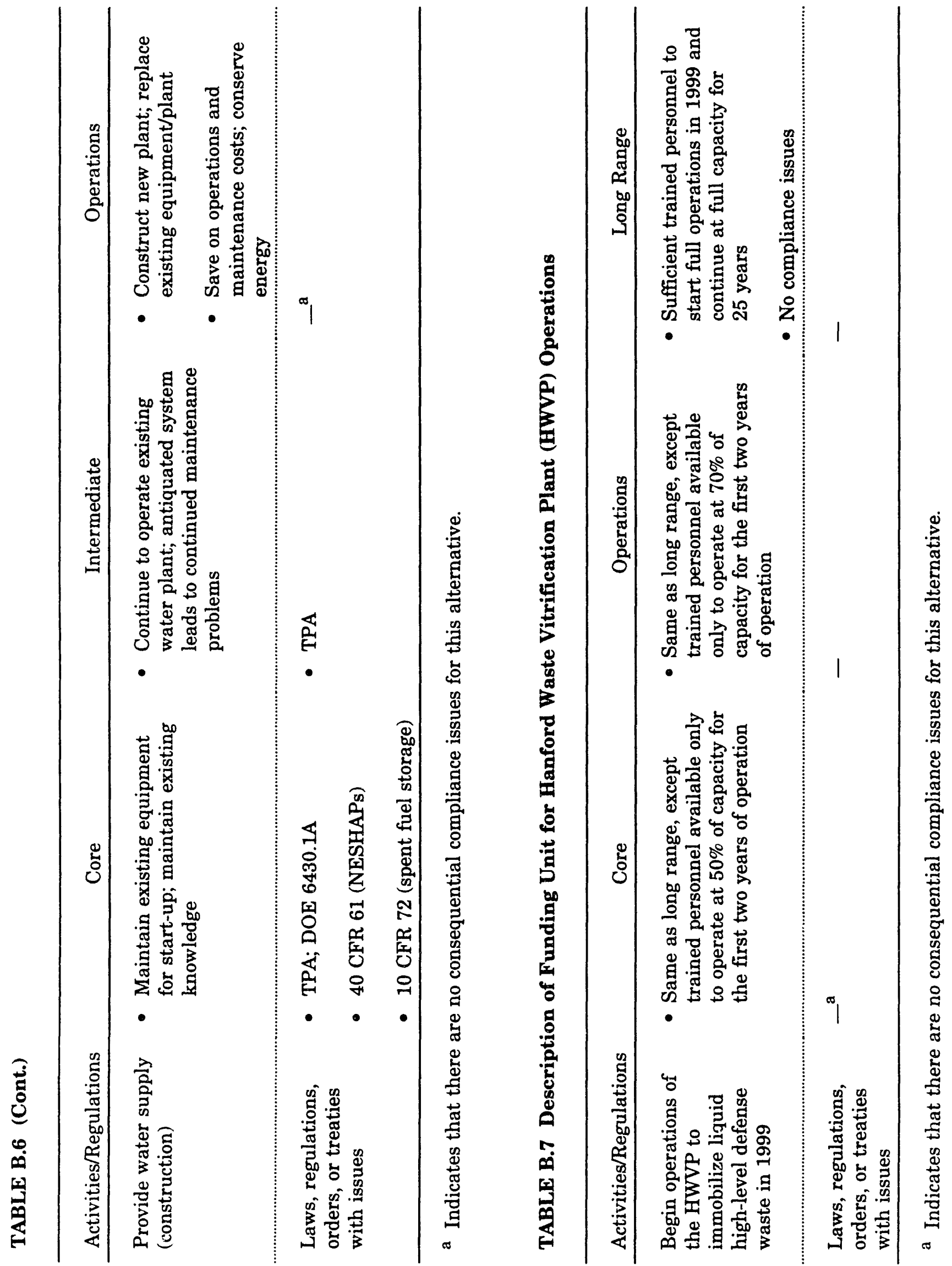

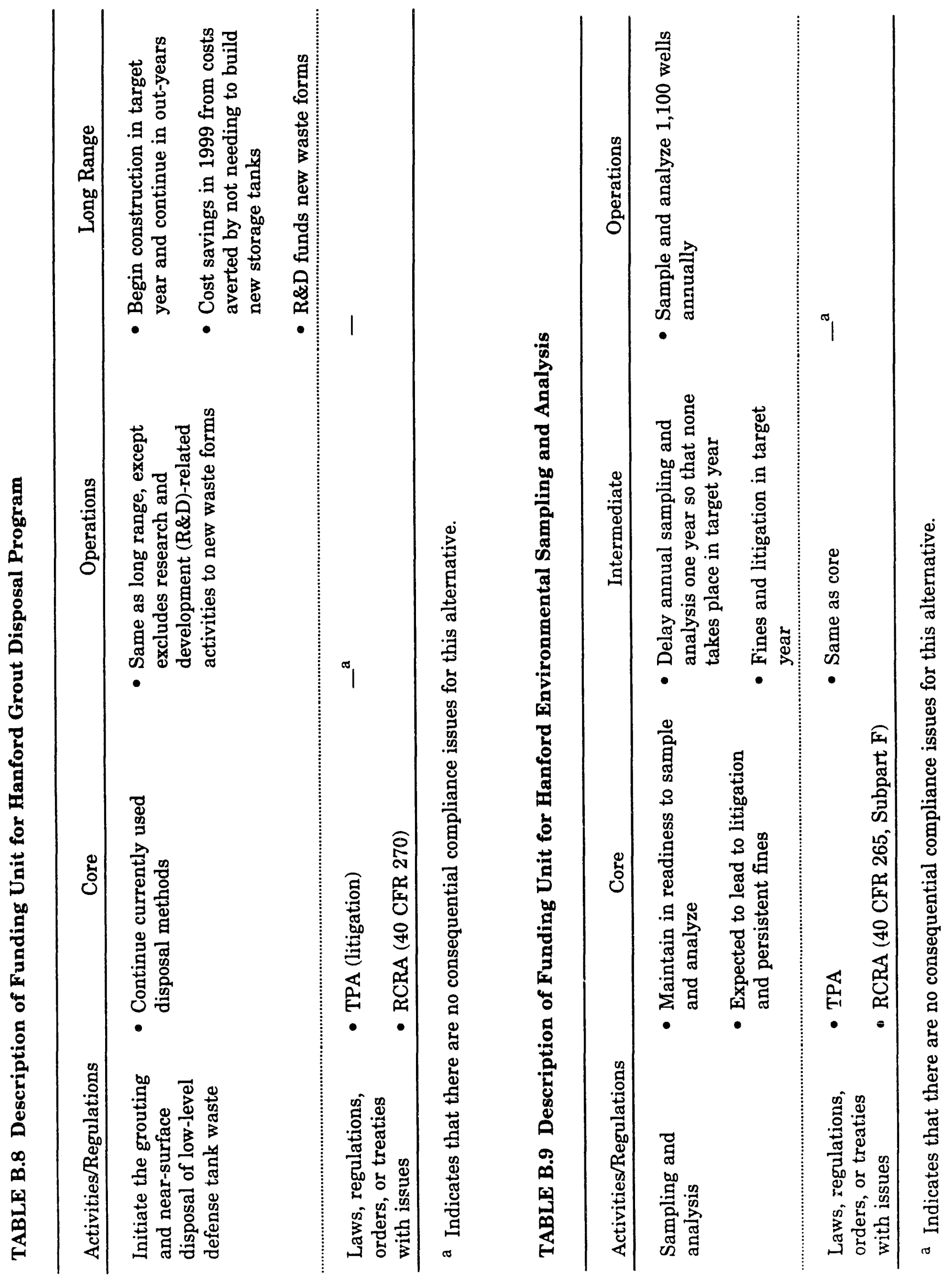


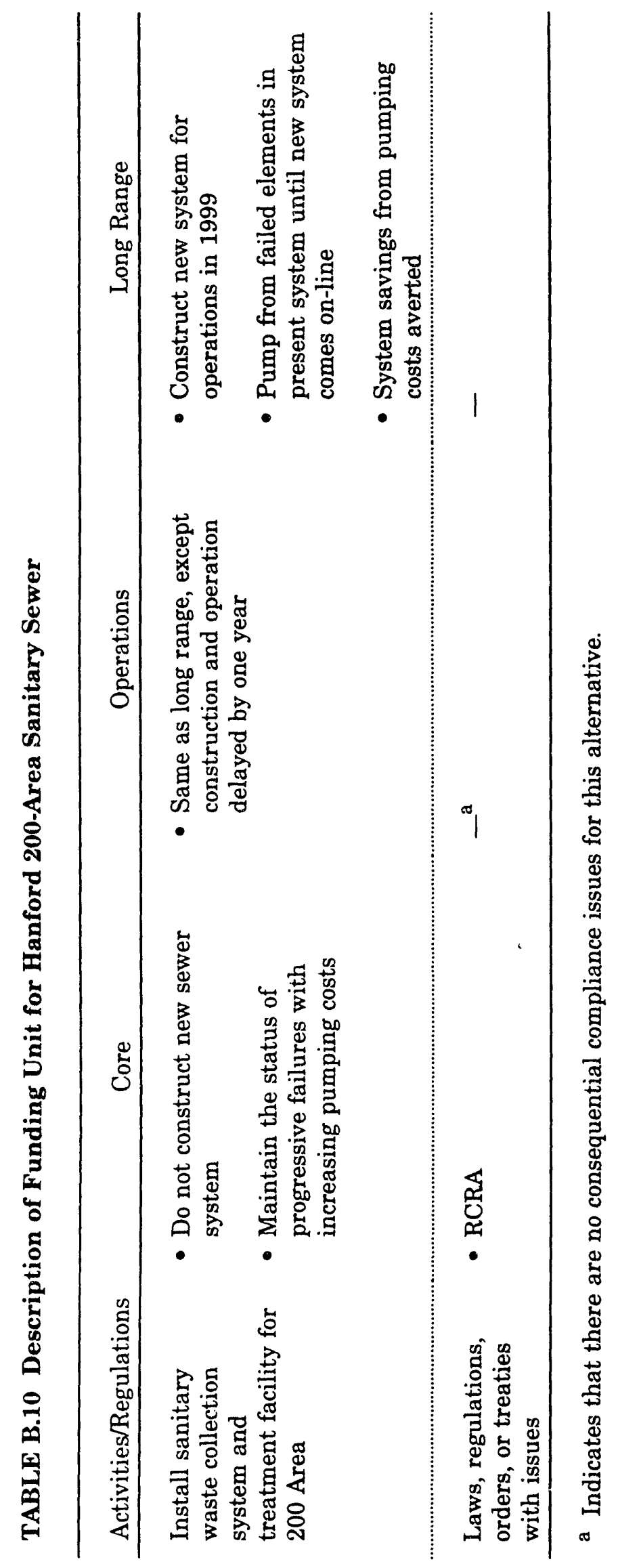




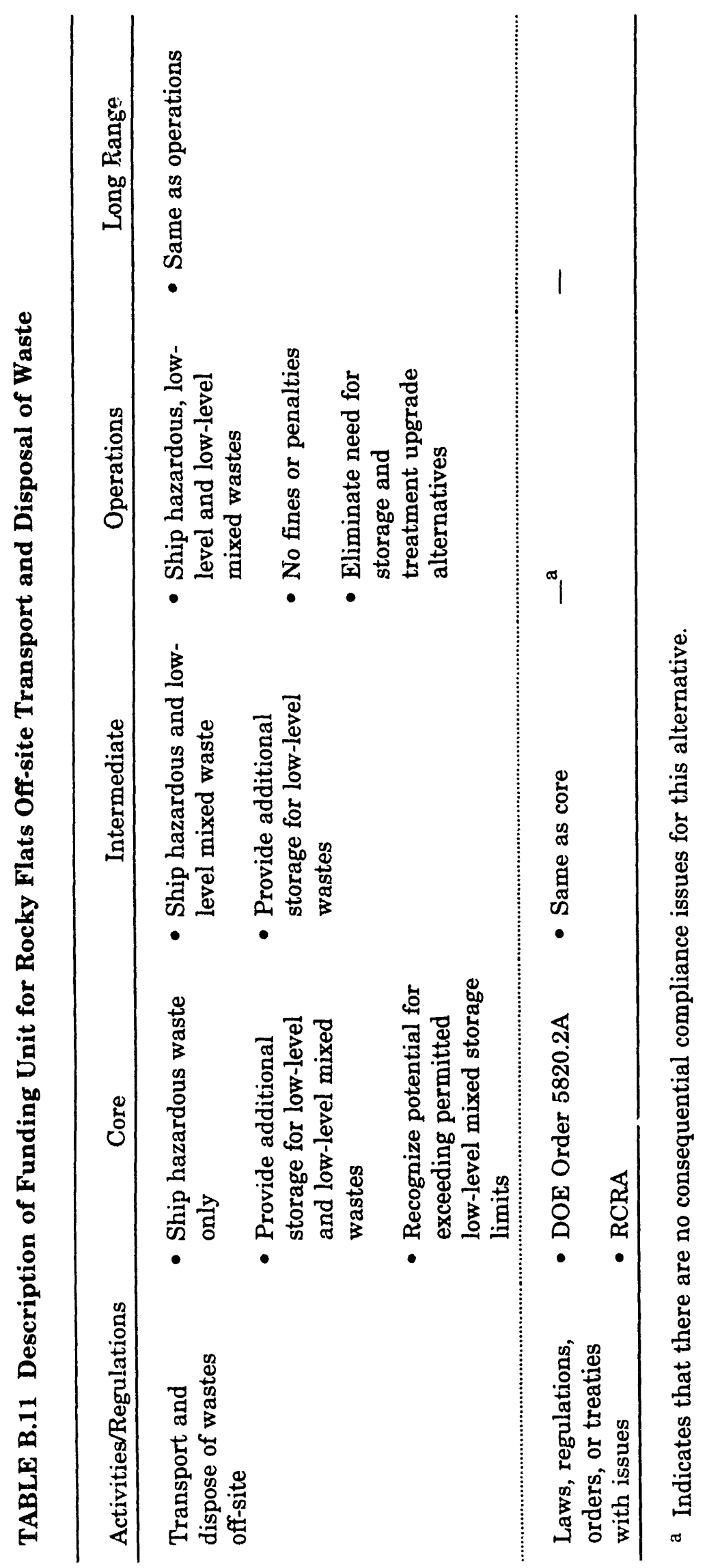




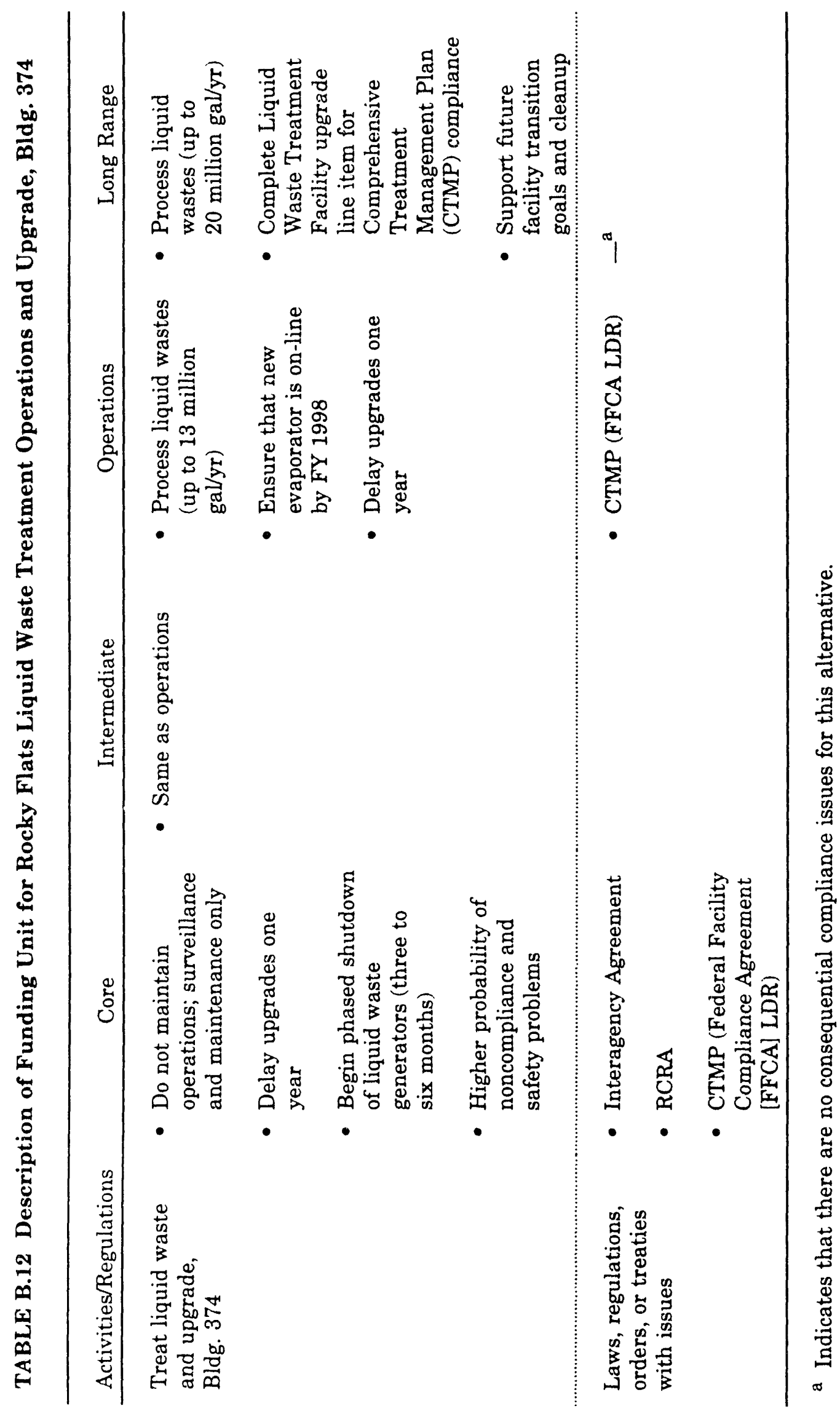



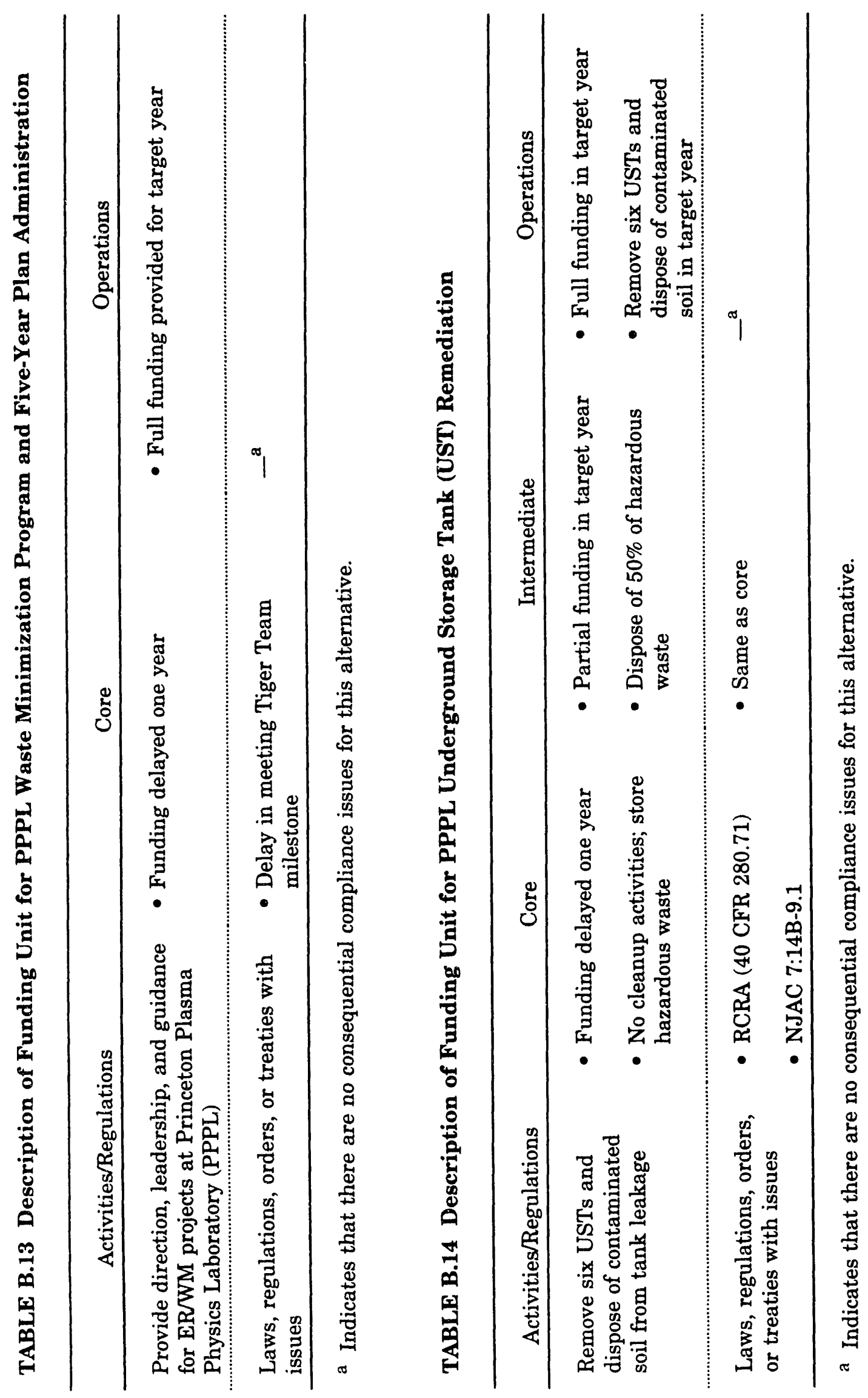

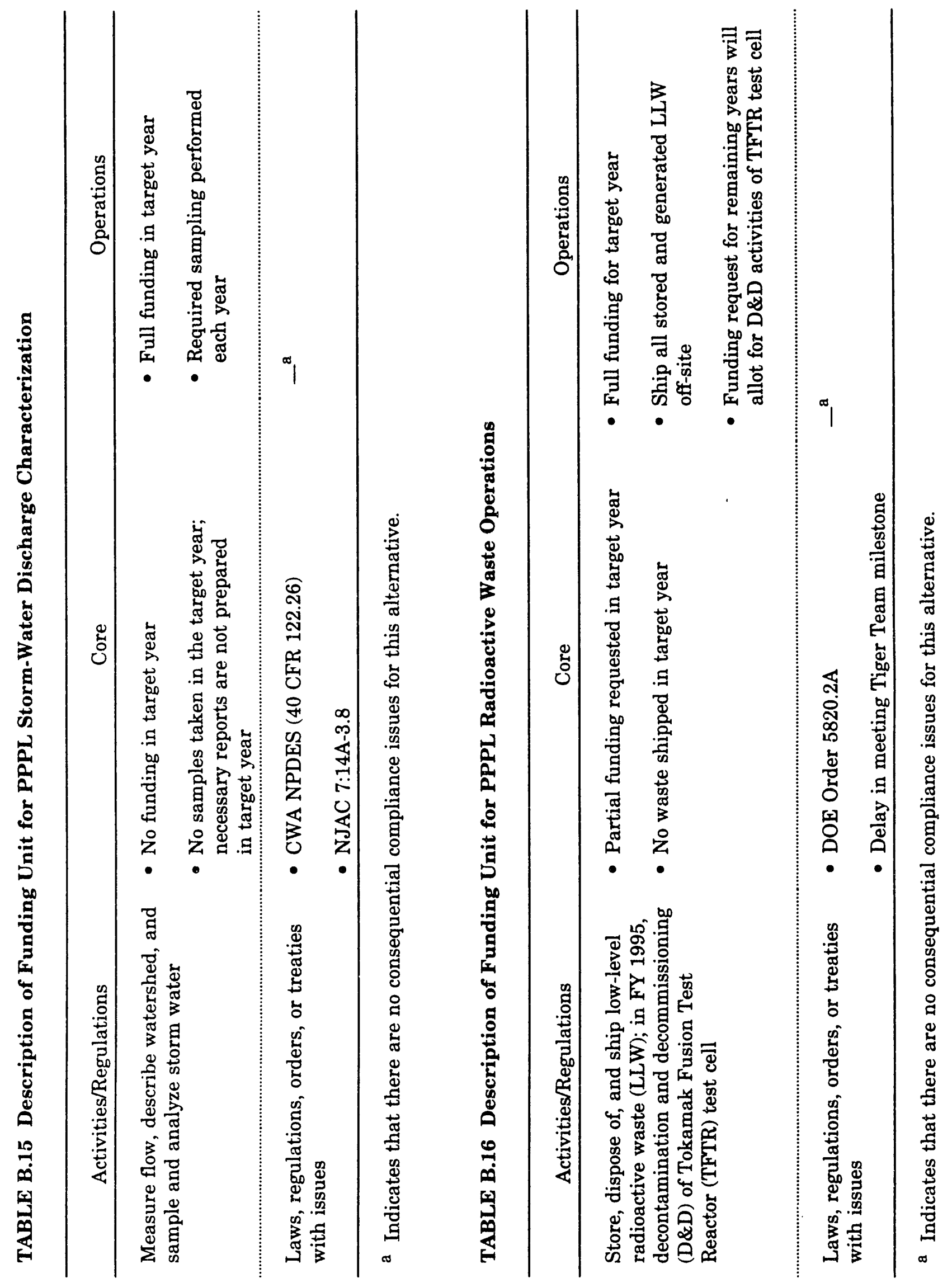


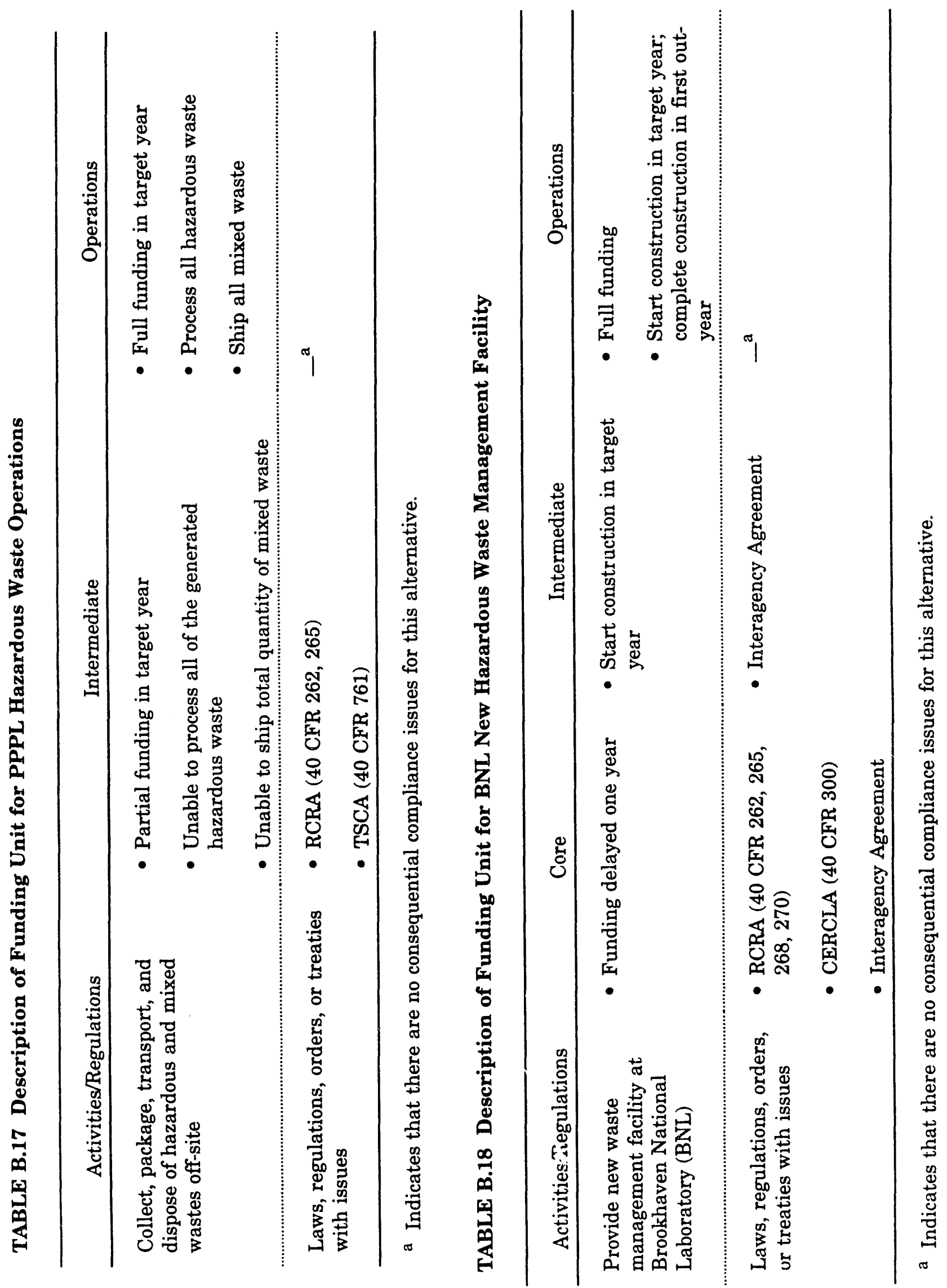




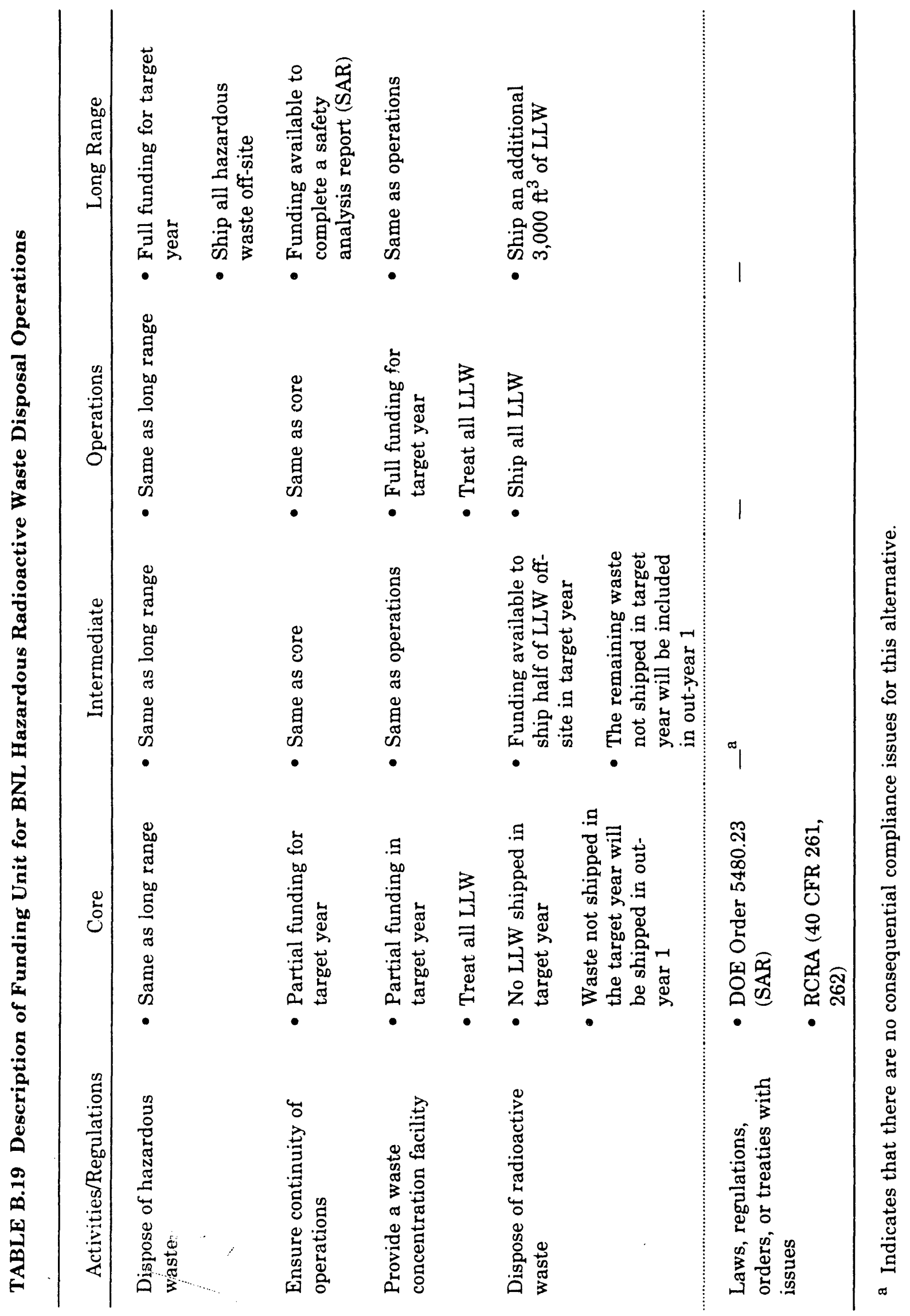



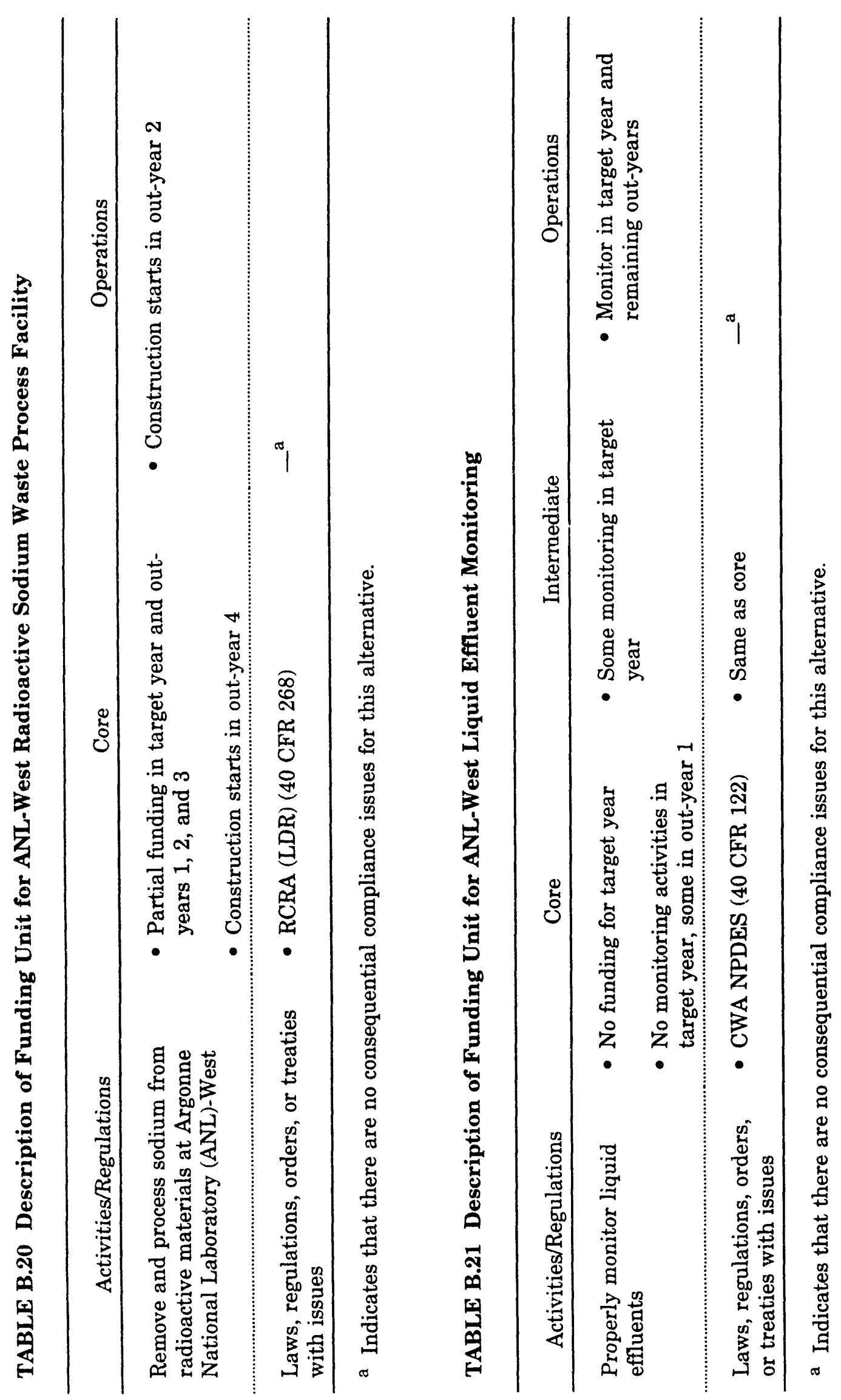

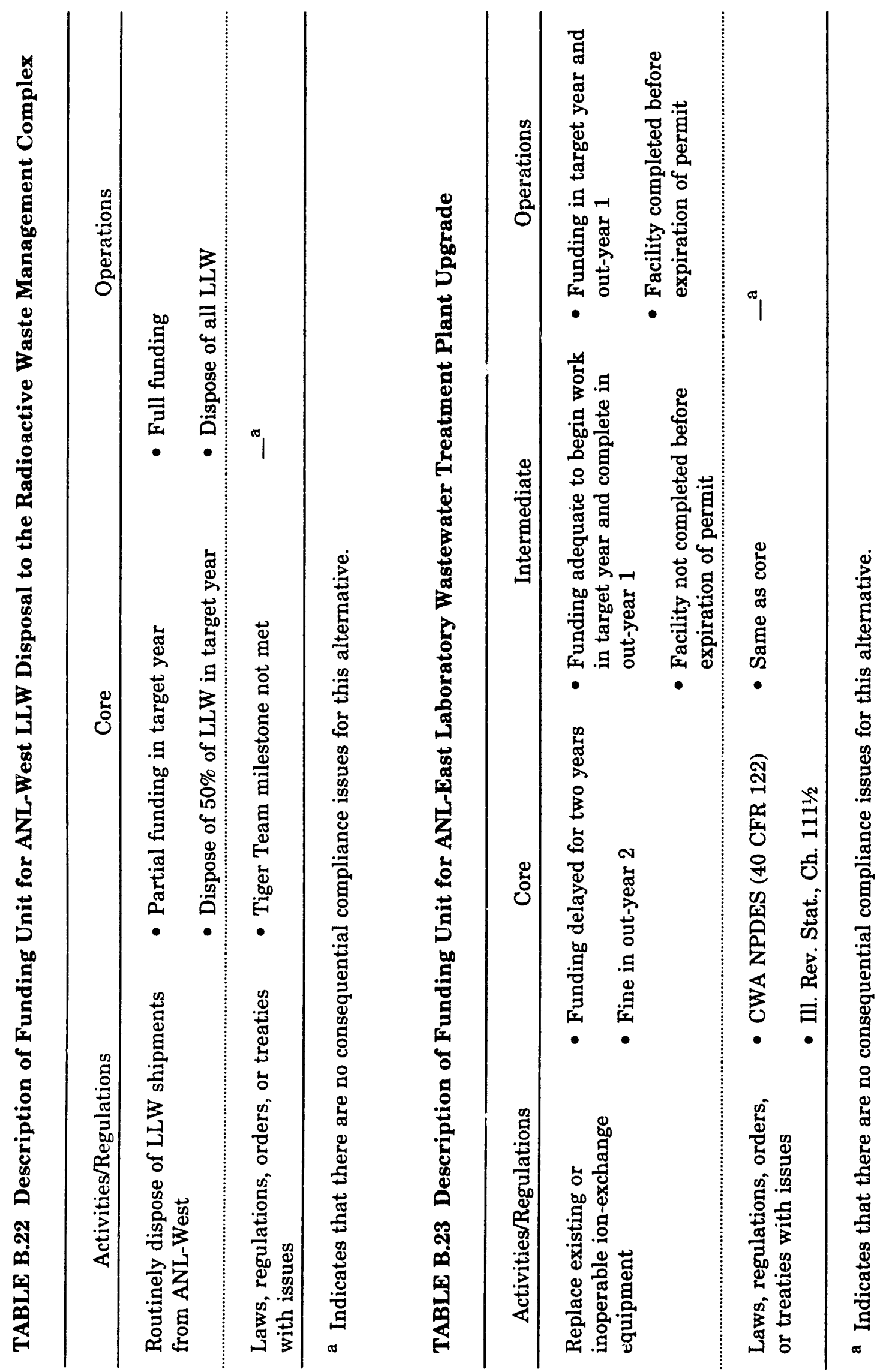


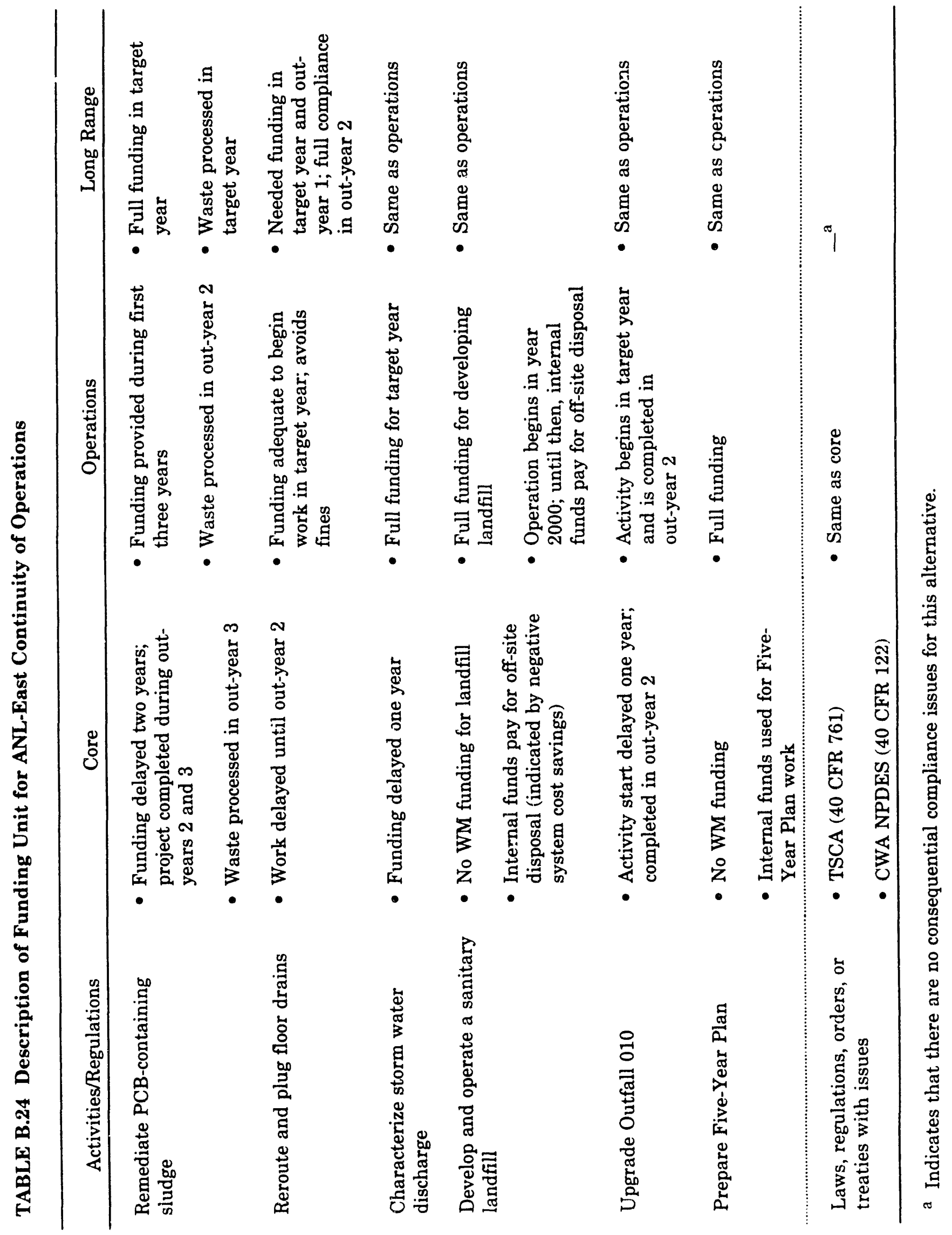




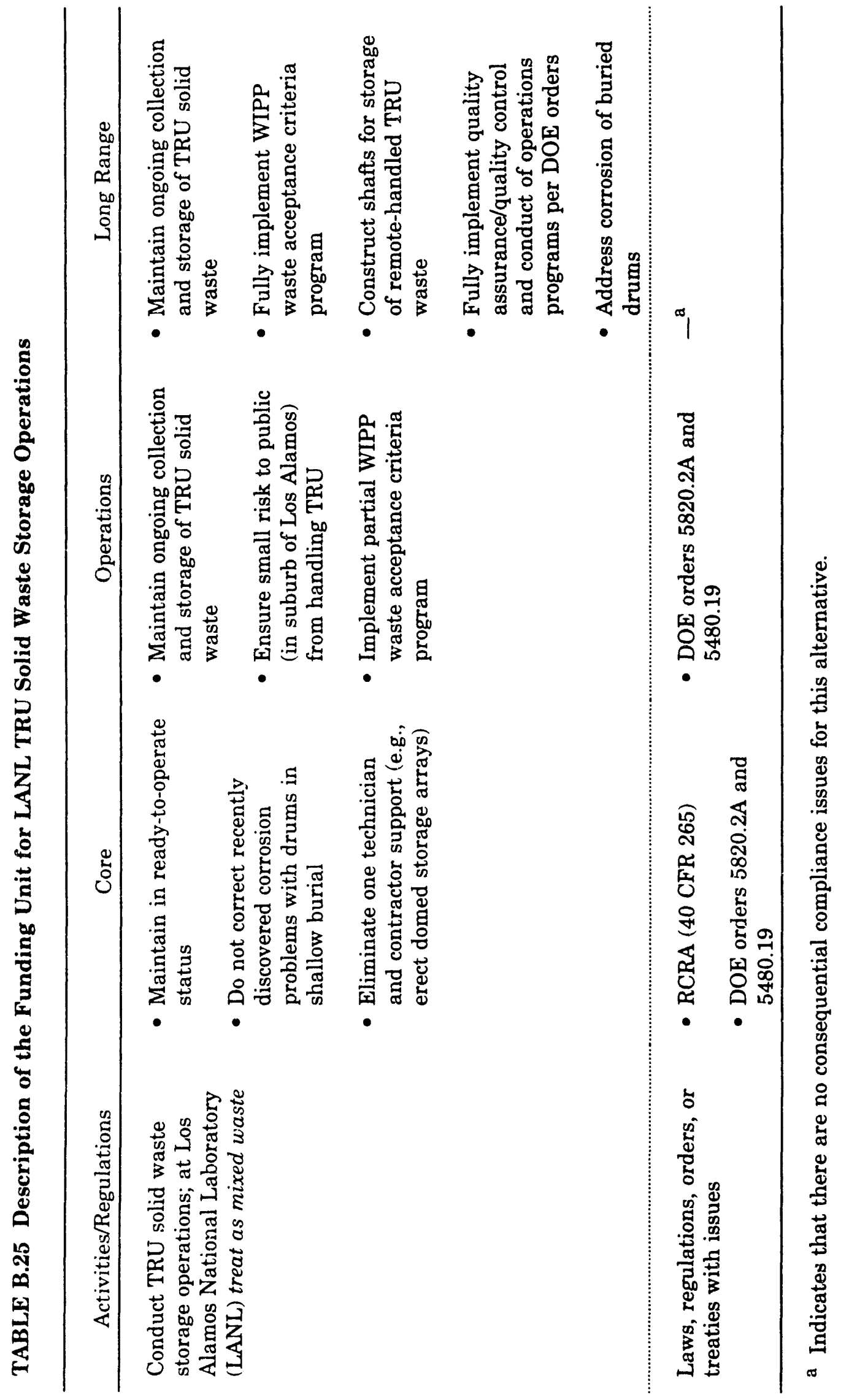




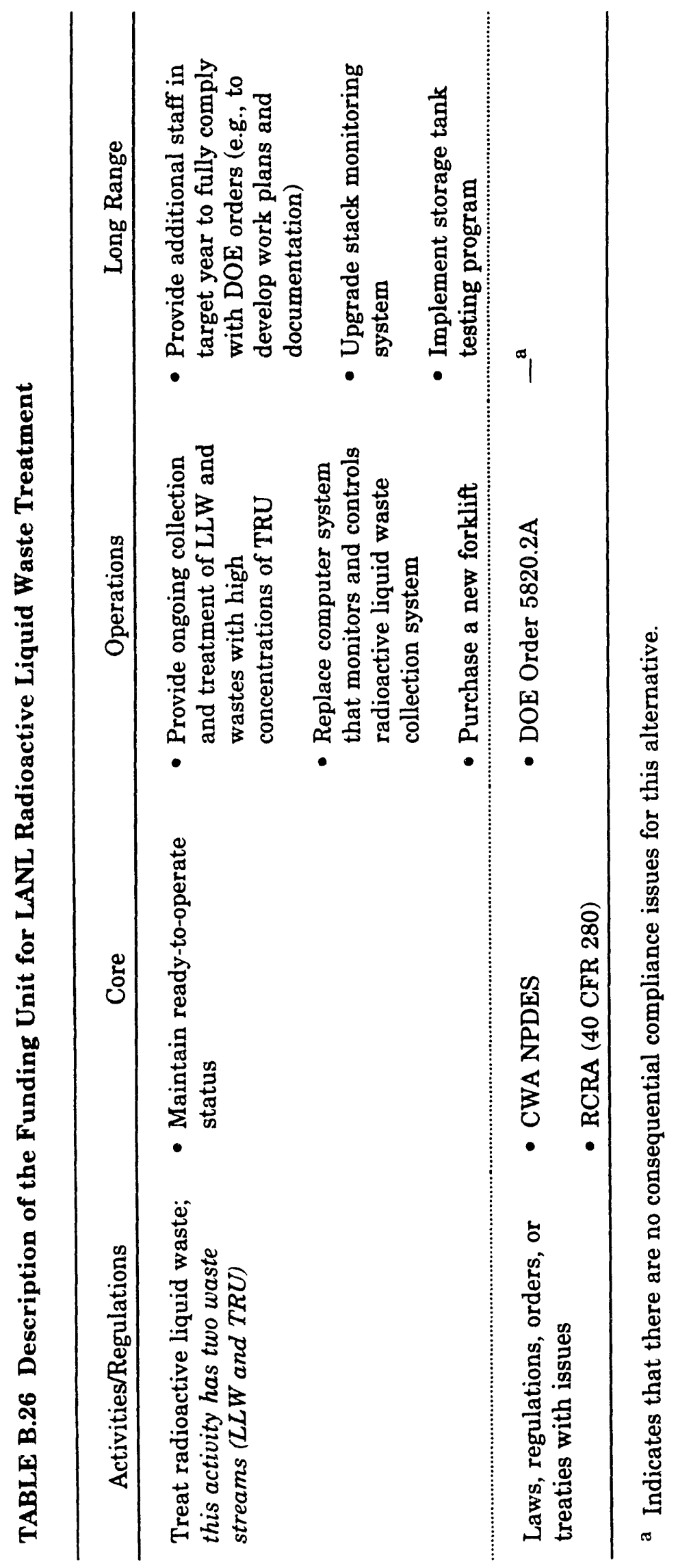




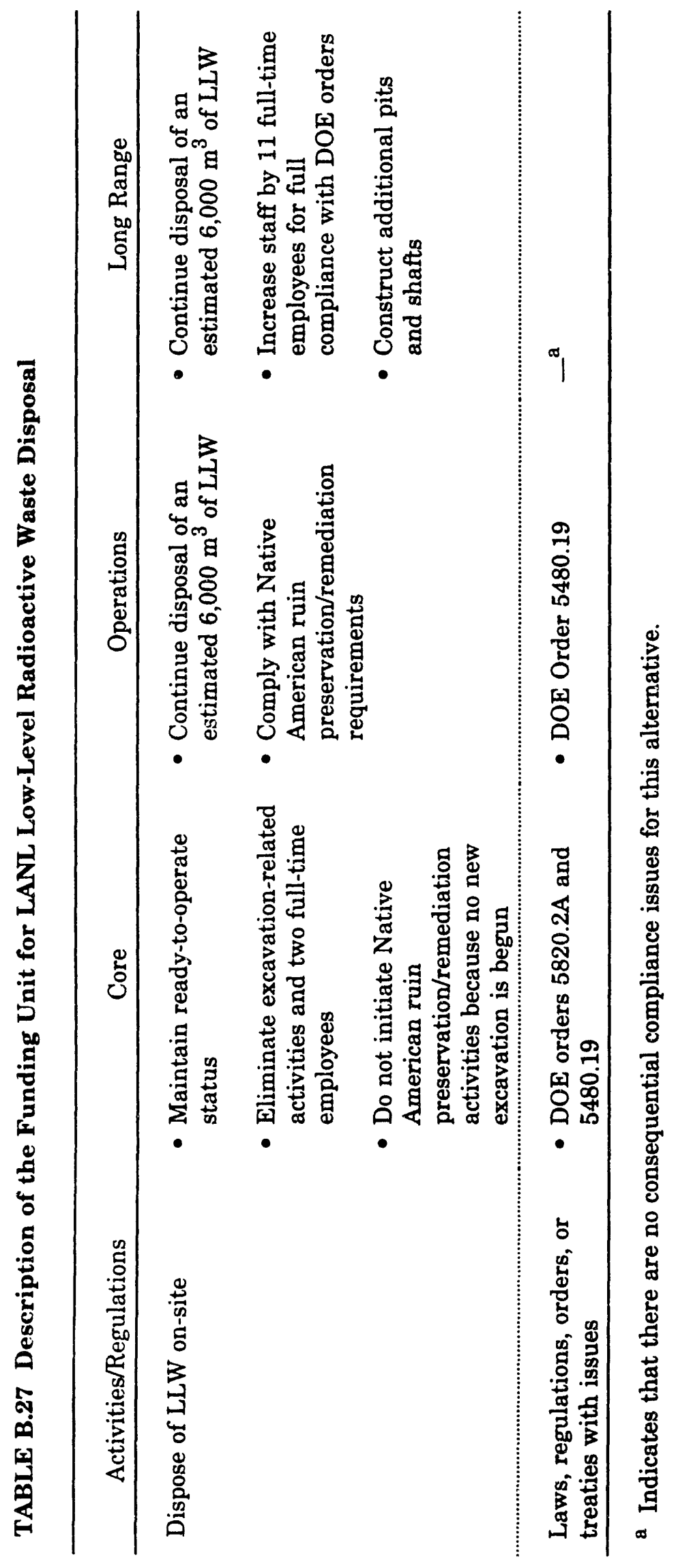




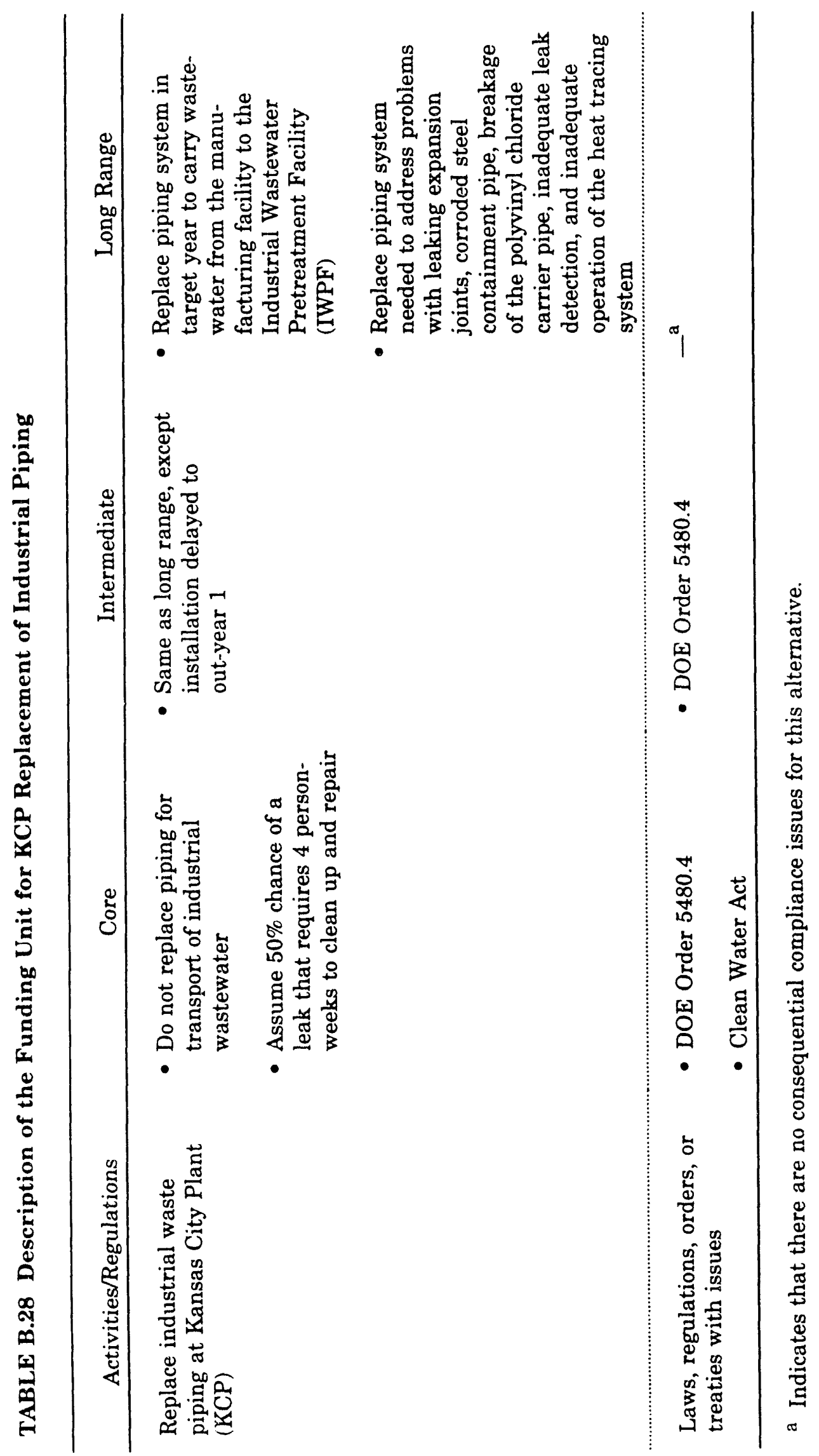




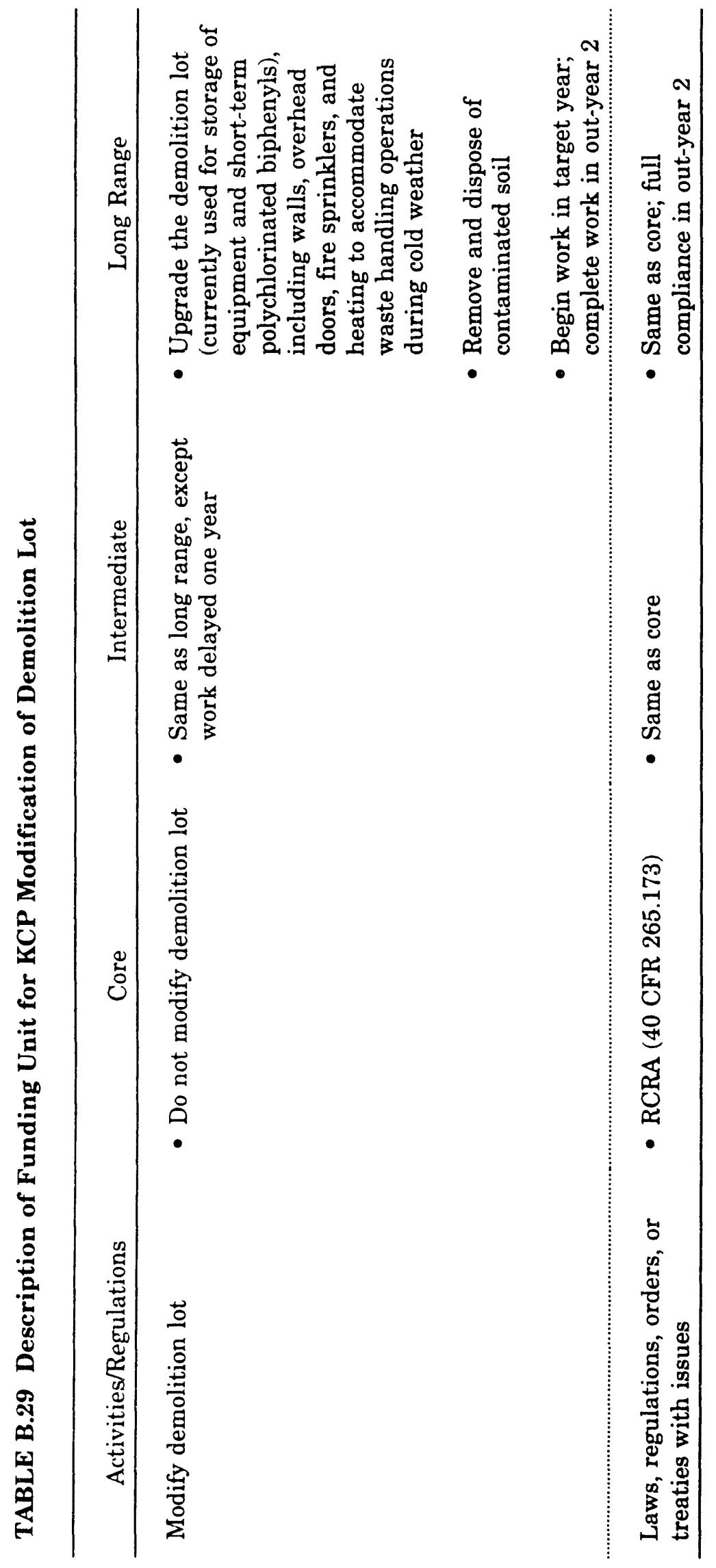




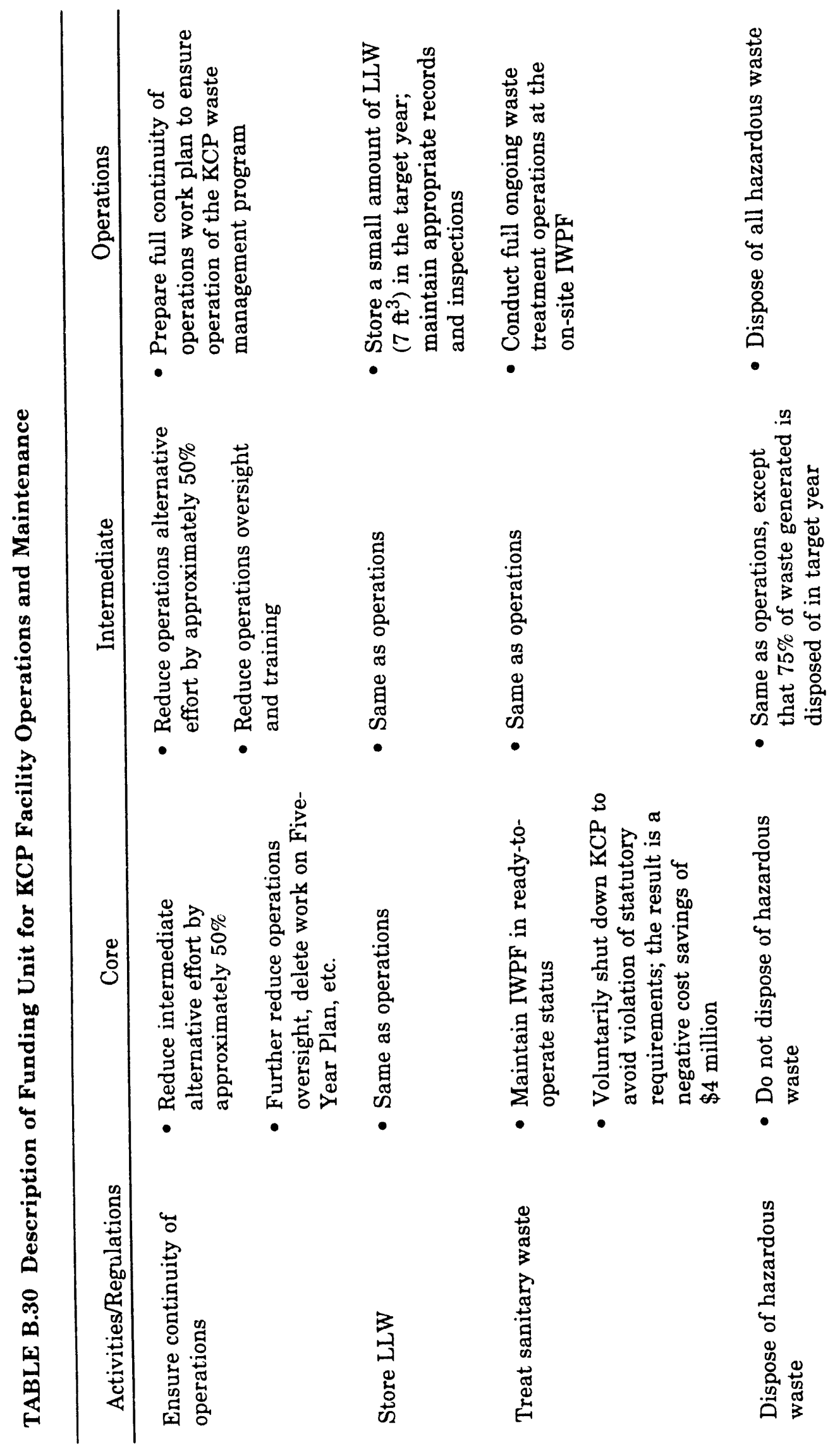




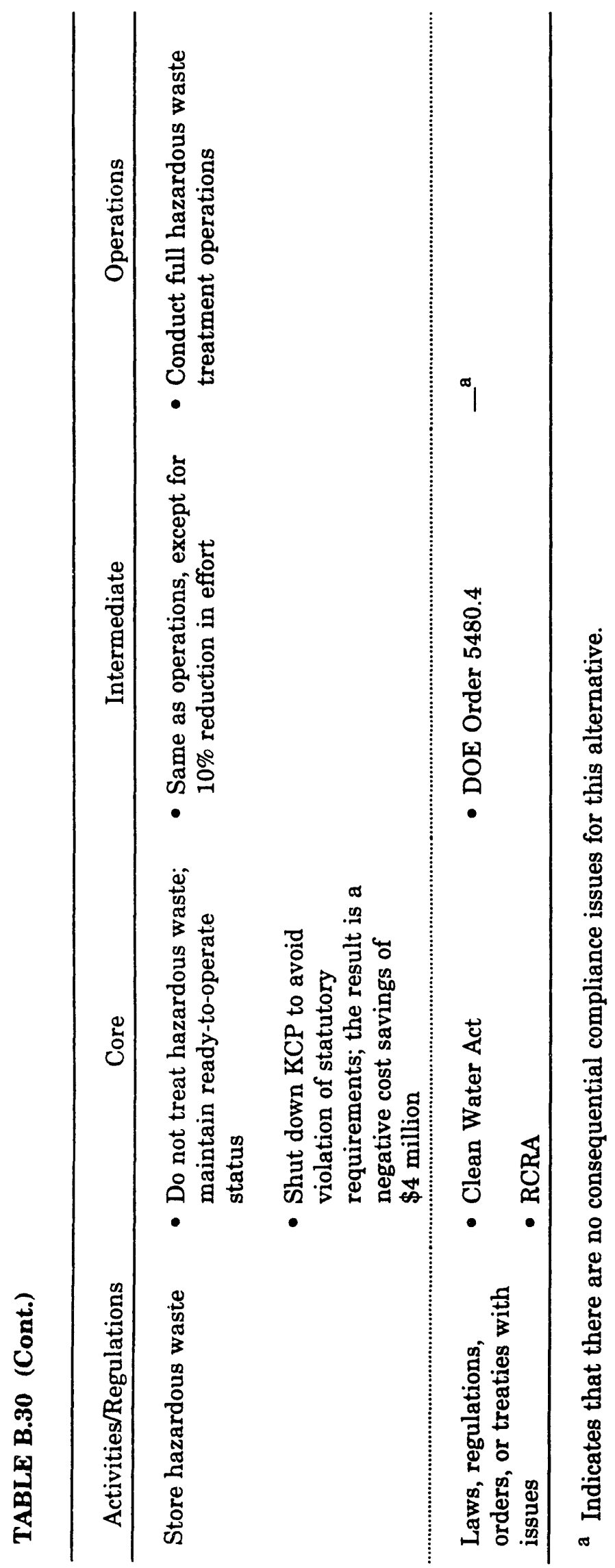




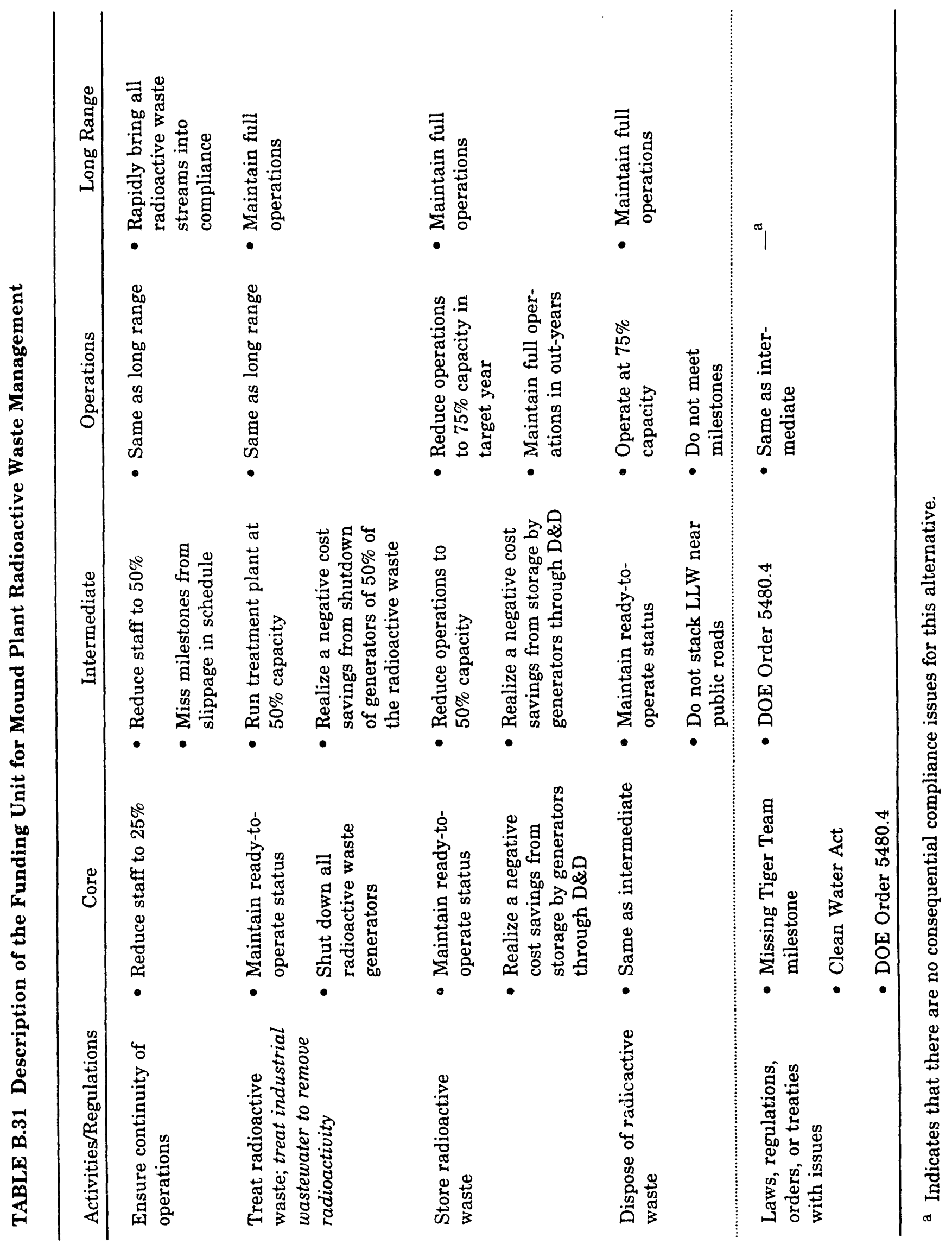




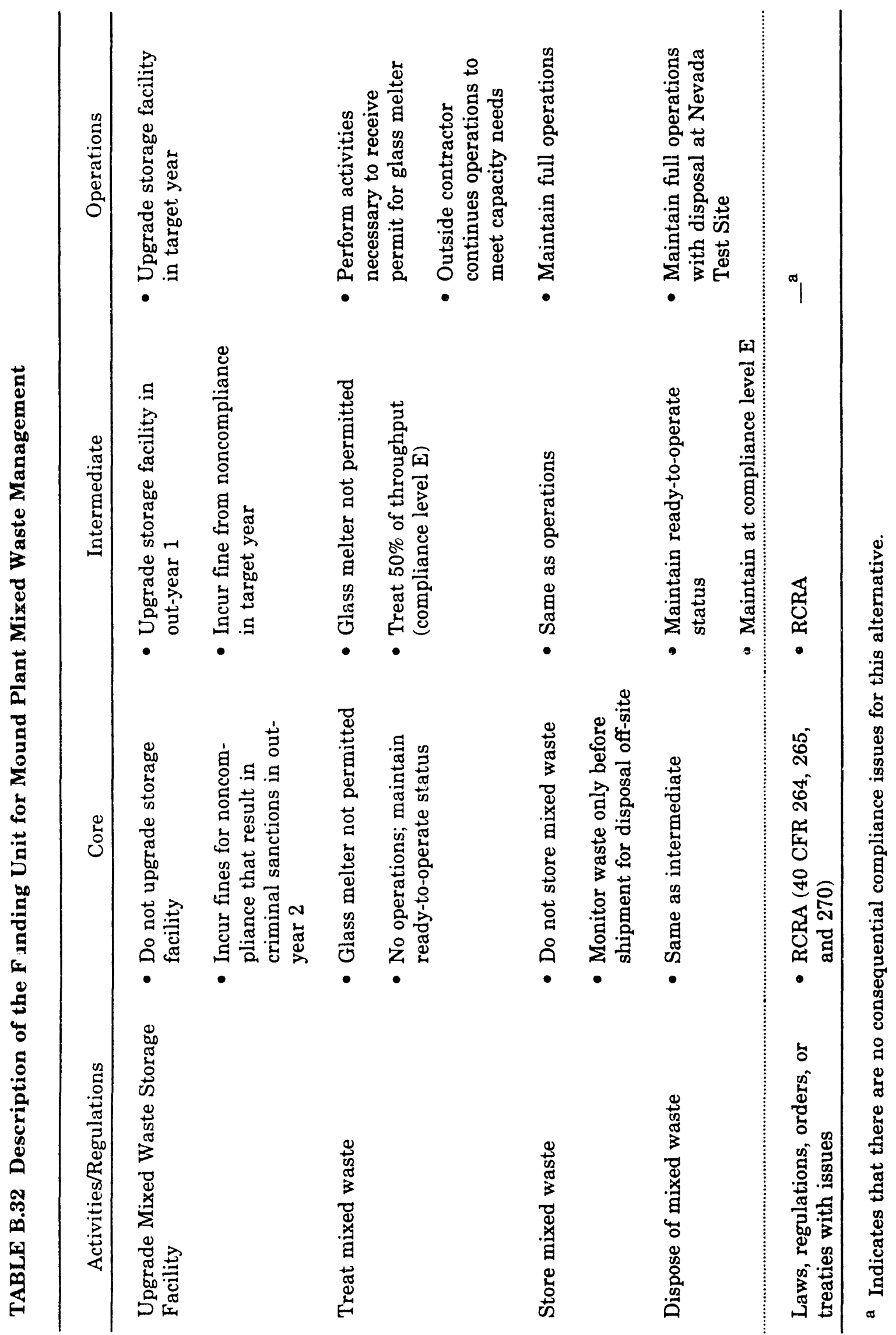




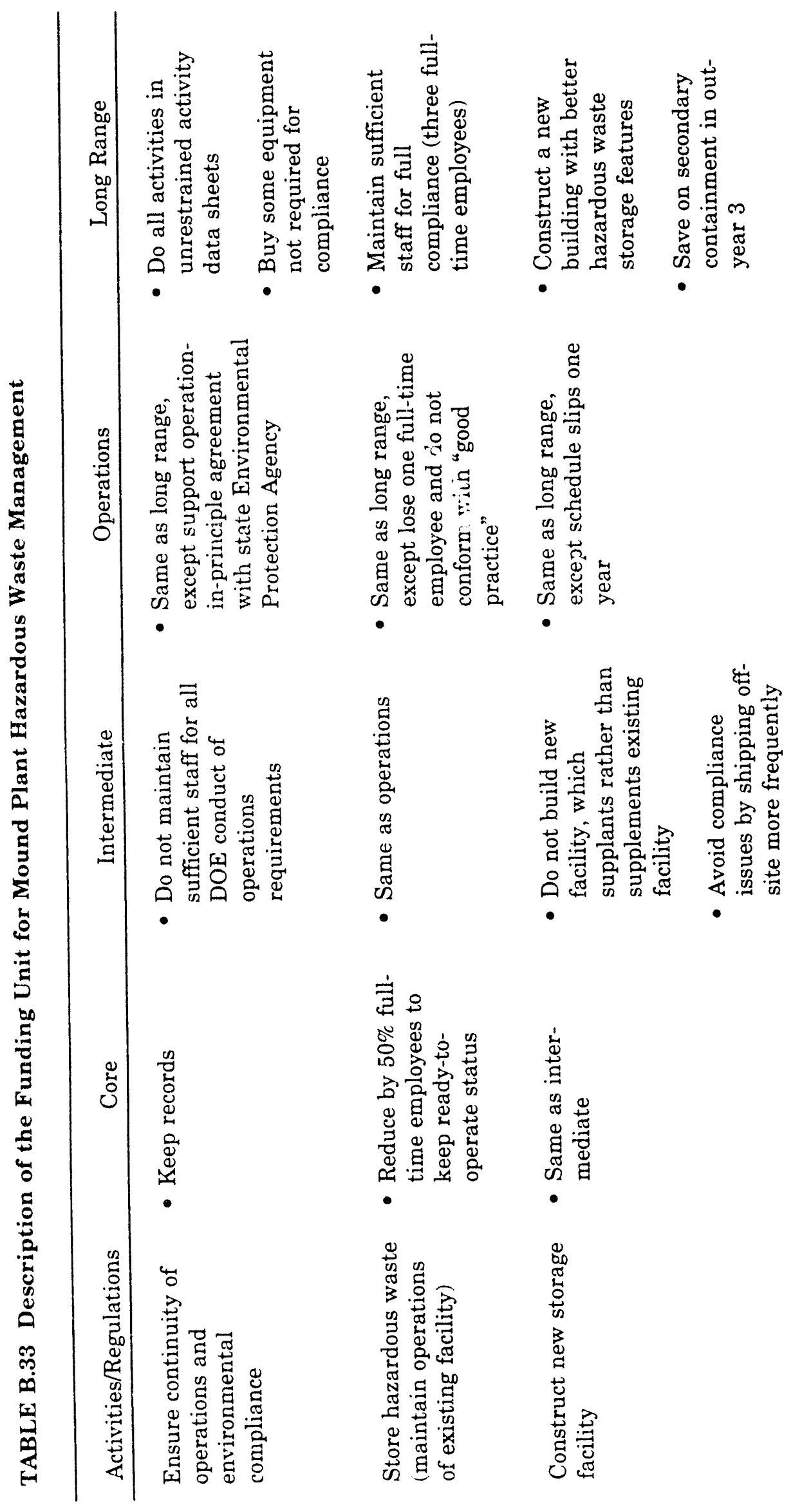




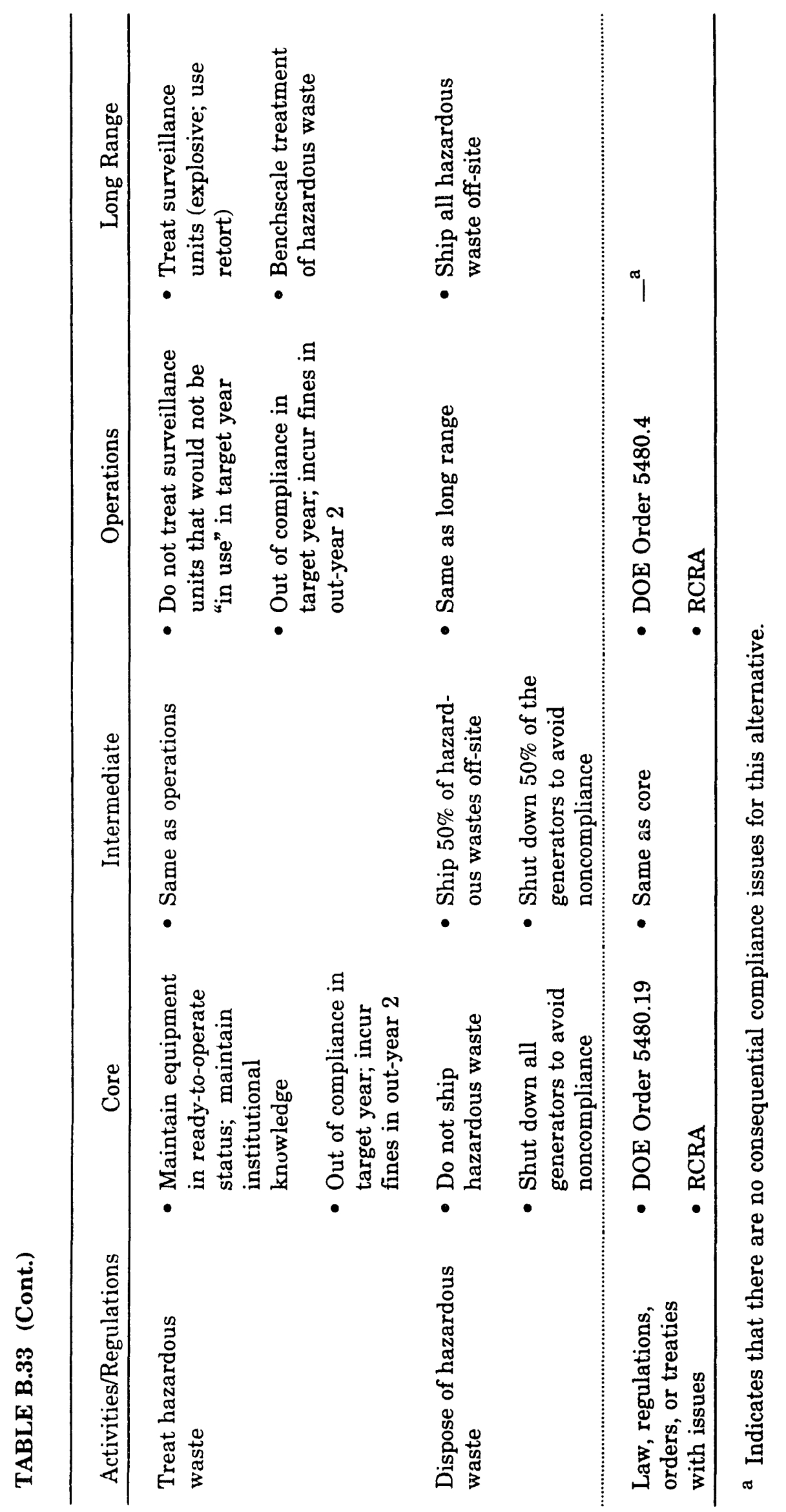




\section{DISTRIBUTION FOR ANL/EAIS-9}

\section{Internal}

ANL Technical Publications Services

M. Clemmons

N. Clodi (5)

R.G. Whitfield (100)

\section{External}

U.S. Department of Energy Office of Scientific and Technical Information (12) Manager, U.S. Department of Energy Chicago Field Office

ANL-E Libraries (2)

ANL-W Library 

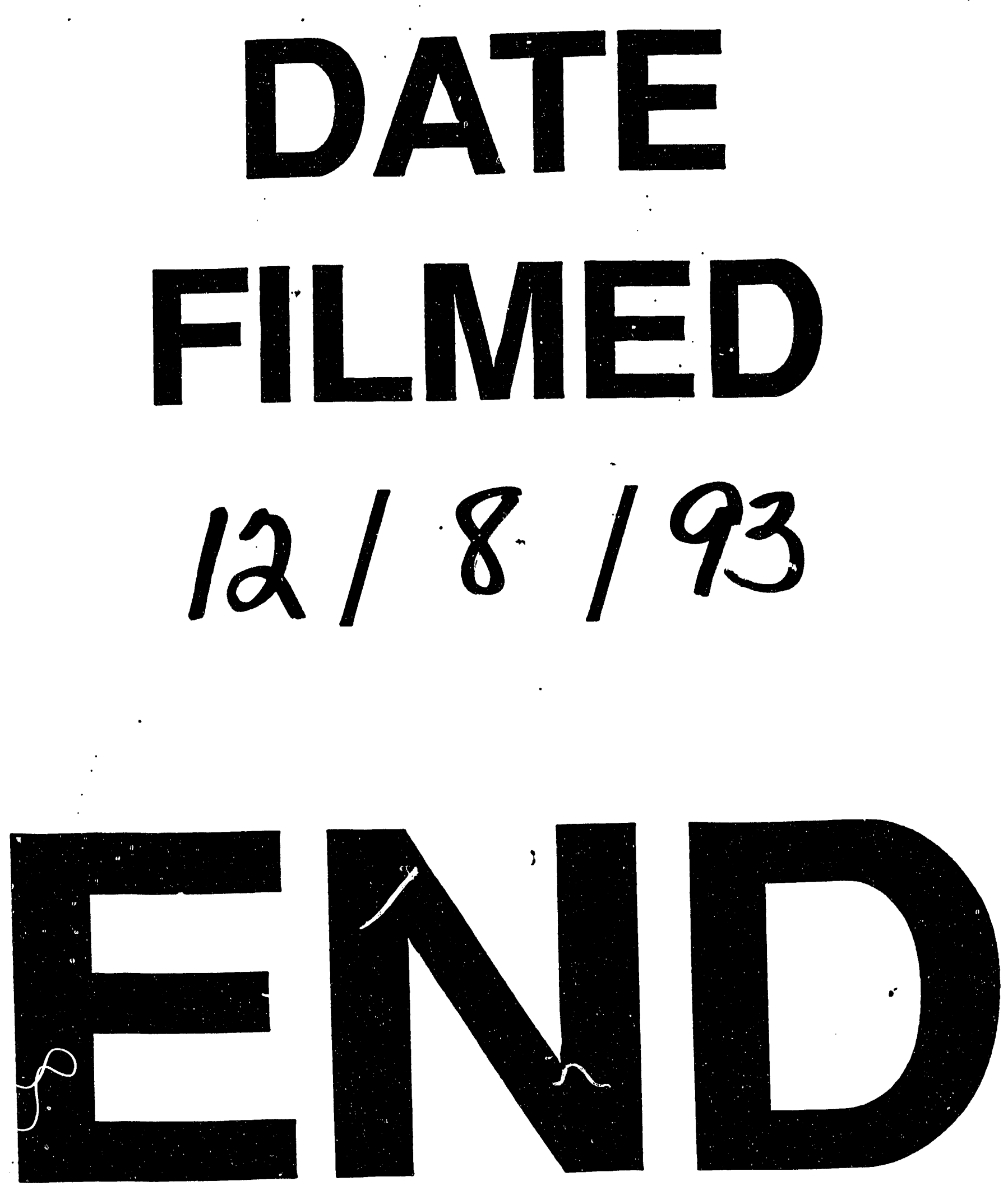
